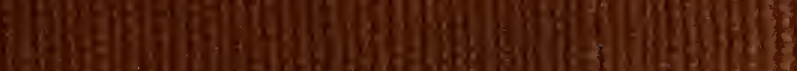

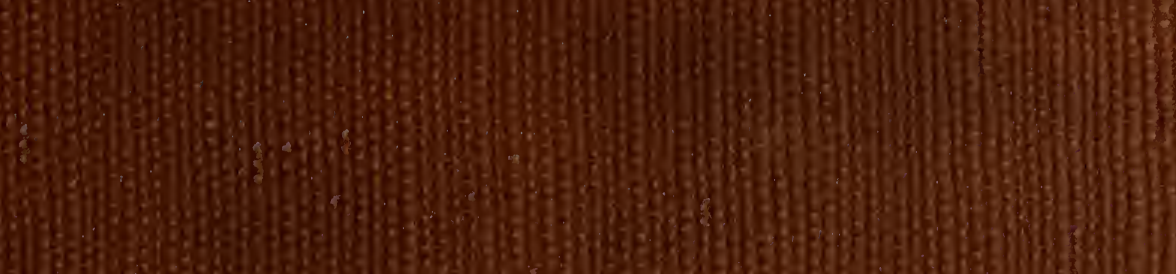
3.7.

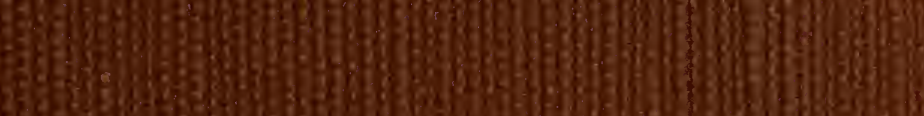




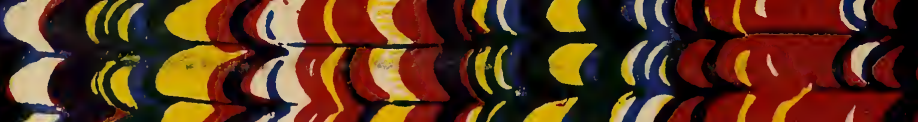

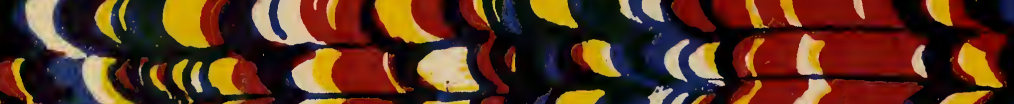
ceser corers

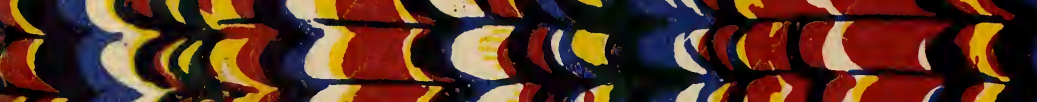

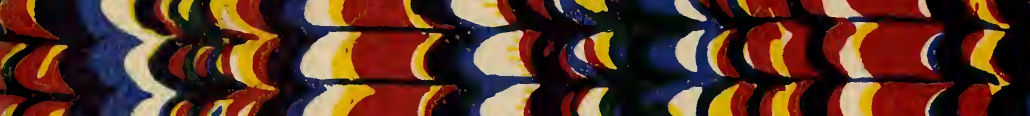
a) a दar (ess

c) दर्वित्र द्रित e tario $\operatorname{coc}$ circarerera ices ces

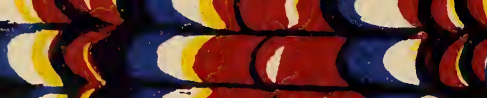

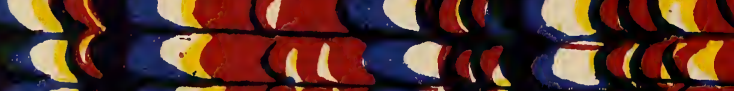

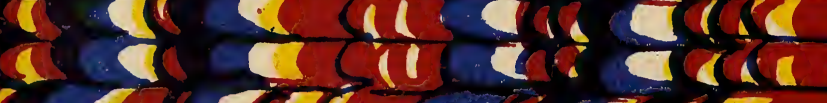

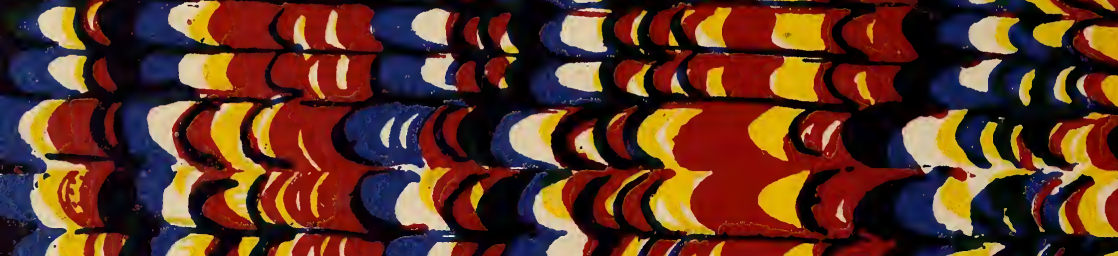

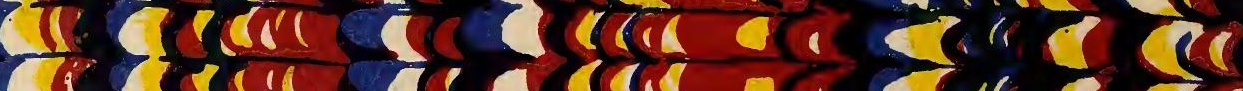

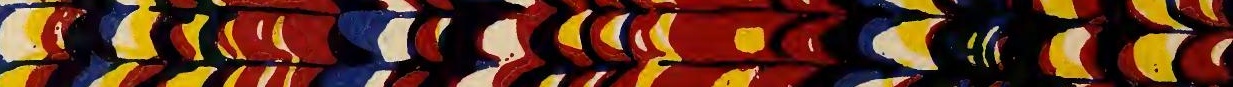

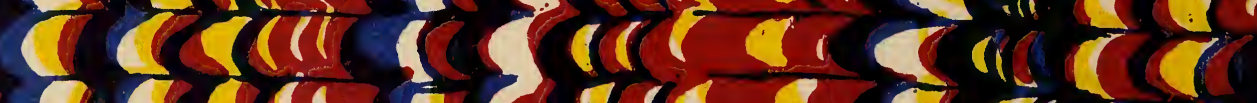

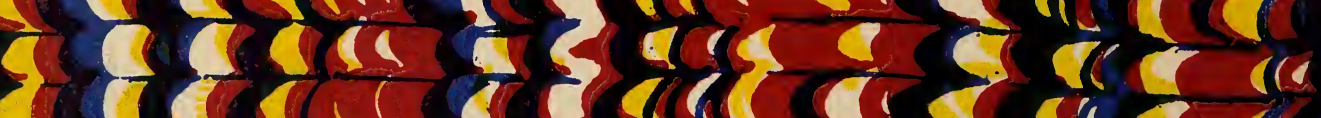

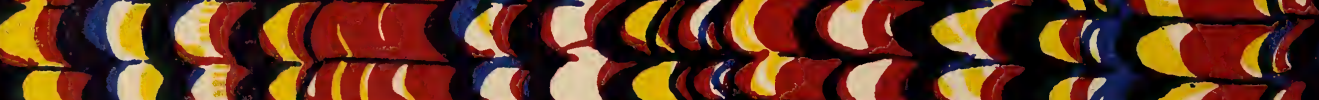

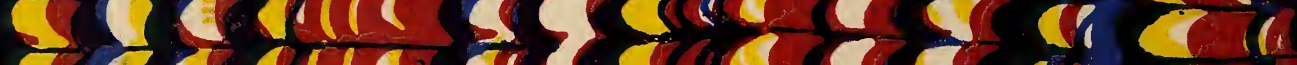

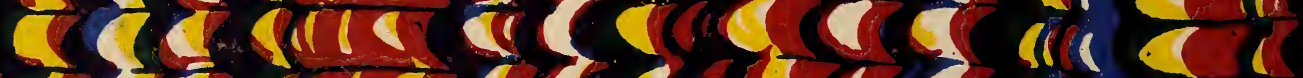

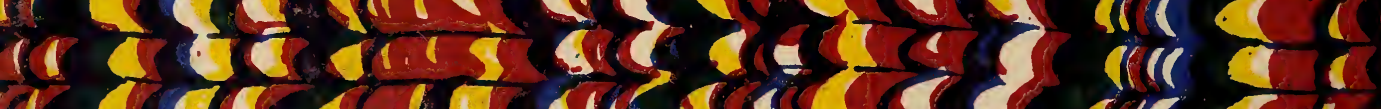
(1)

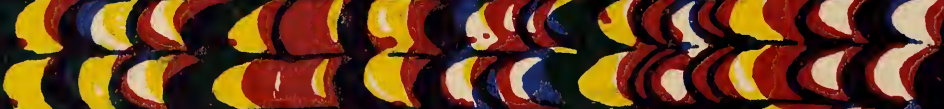

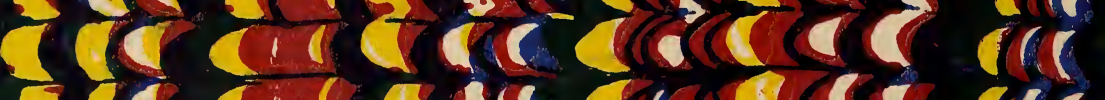

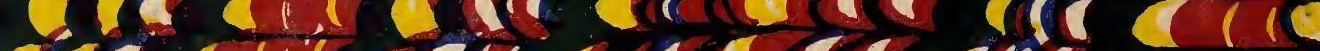

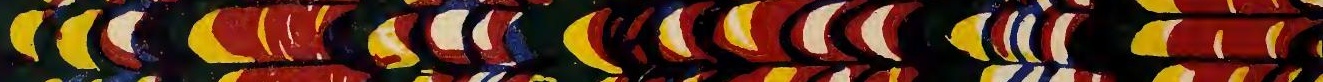

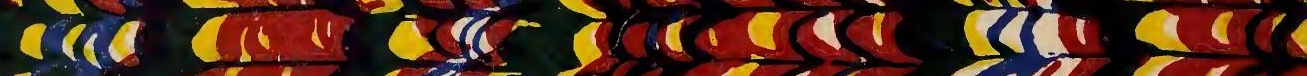

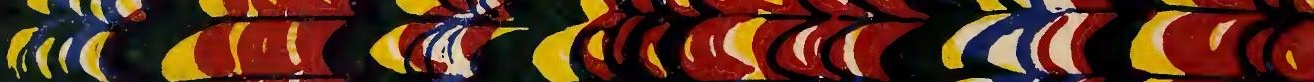

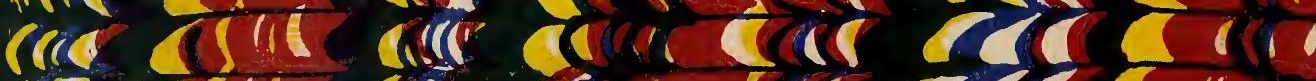

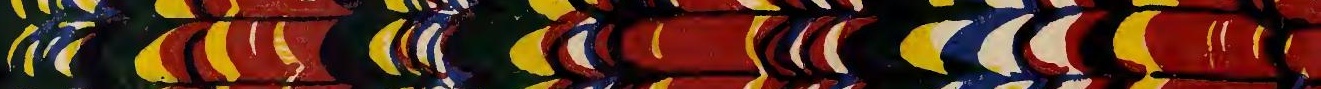

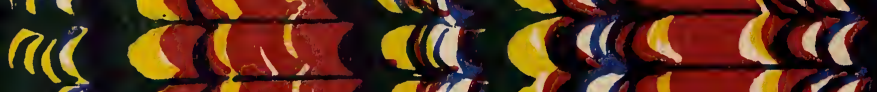

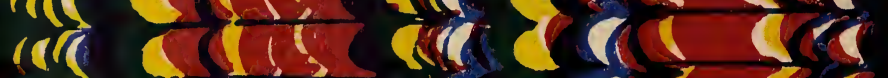

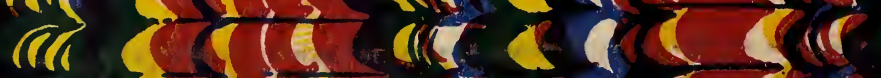









\section{BRITISH FERNS.}






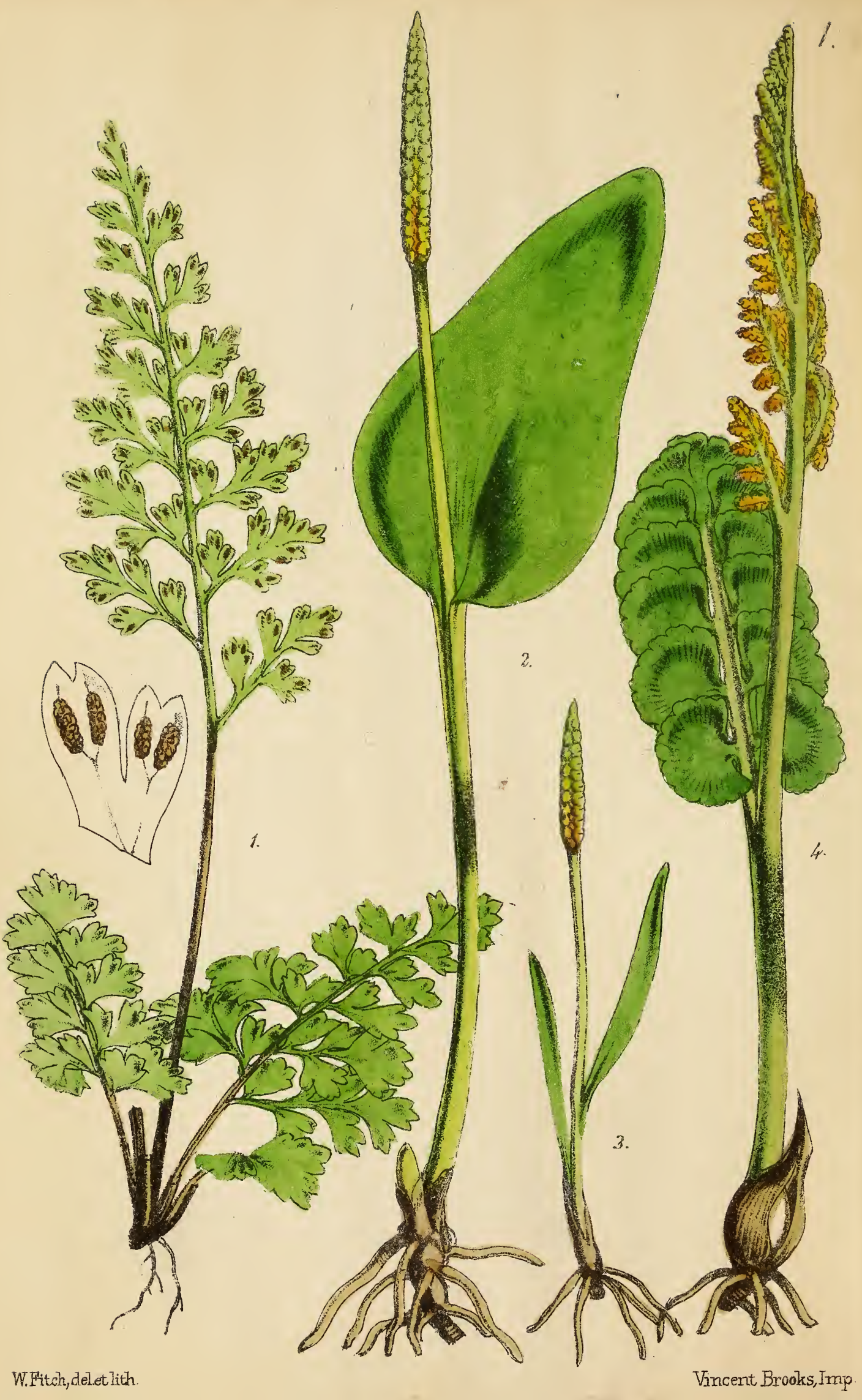




\title{
BRITISH FERNS:
}

\author{
AN INTRODUCTION
}

TO THE STUDY OF

THE FERNS, LYCOPODS, AND EQUISETA

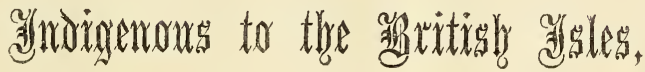

WITH CHAPTERS ON THE STRUCTURE, PROPAGATION, CULTIVATION, DISEASES, USES, PRESERVATION, AND DISTRIBUTION OF FERNS.

BY

MARGARET PLUES.
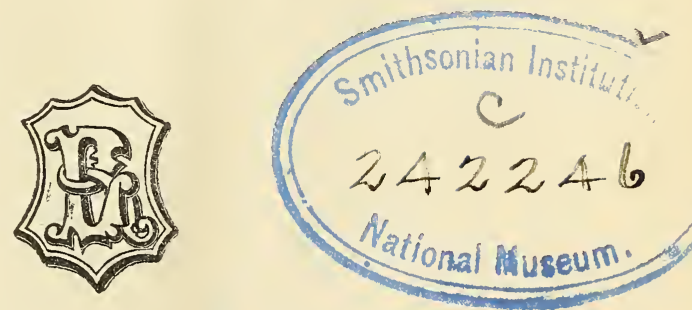

IONDON :

LOVELL REEVE \& CO., 5, HENRIETTA STREET, COVENT GARDEN.

1866. 
J. E. TAYLOR AND CO., PRINTERS, FITTLE QUEEN STREET, LINCOLN'S INN FIELDS. 


\section{$\begin{array}{r}587.30 \\ -073 \\ \hline\end{array}$}

Q

\section{PREFACE。}

Considering the number of works upon Ferns already before the public, it may seem necessary to offer some apology for adding another; but this is a matter of seeming rather than of fact, for it is universally acknowledged that the demand creates the supply, and we therefore present our new "Introduction" with full confidence in the sympathy and welcome it will receive from the genial Fern-lovers, to please whom we have laboured diligently in its preparation. To assist their efforts in studying, collecting, and cultivating, we have searched extensively in public libraries and botanical periodicals, as well as among the hills and dales of our own and other countries, and in the ferneries of distin. guished cultivators; and we have little doubt of their accepting our simple work in the same spirit in which we offer it to them. Their desire and ours is to under- 
stand and possess as many members of the Fern family as possible, and to make our immigrants so comfortable that they shall quite forget that they are not growing where they planted themselves. To this intent we have written, and to this intent we invite you to read, expecting only practical information from a work which makes no pretension to learning, and is simply what it calls itself-an Introduction. 


\section{CONTENTS.}

CHAPIER I.

INTRODUCTION

CHAPTER II.

STRUCTURE

CHAPTER III.

PROPAGATION . . . . . . . . . . . . 15

CHAPTER IV.

CULTIVATION IN FERNERIES . . . . . . . . . 19

CHAPTER V.

CULTIVATION IN WARDIAN CASES AND GREENHOUSES • . 28

CHAPTER VI.

CULTIVATION IN HOTHOUSES . . . . . . . . 45

CHAPTER VII.

DISEASES OF FERNS . . . . . . . . . . 72

CHAPTER VIII.

USES OF FERNS . . . . . . . . . . . . 74 
viii

CONTENTS。

CHAPTER IX.

PAGE

PRESERVATION FOR THE HERBARIUM

CHAPTER X.

DISTRIBUTION OF THE FERN GROUP . . . . . . 90

CHAPTER XI.

\begin{tabular}{l} 
CLASSIFICATION \\
BRITISH FERIS \\
\hline
\end{tabular}

CHAPTER XII.

LOCAI DISTRIBUTION OF BRITISH FERNS . . . . . 217

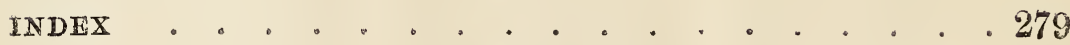




\section{LIST OF PLATES.}

Plate I.

1. Gymnogramme leptophylla.

2. Ophioglossum vulgatum.

3. Ophioglossum vulgatum angustifolium.

4. Botrychium Lunaria.

\section{Plate II.}

1. Asplenium viride.

2. Asplenium Trichomanes.

3. Polypodium vulgare.

Plate III.

Polypodium Phegopteris.

$$
\text { Plate IV. }
$$

Polypodium Dryopteris.

$$
\text { Plate V. }
$$

Polypodium Robertianum.
Plate VI.

1. Woodsia hyperborea.

2. Woodsia Ilvensis.

Plate VII.

1. Aspidium Lonchitis.

2. Cryptogramme crispa.

Plate VIII.

Nephrodium Thelypteris.

$$
\text { Plate IX. }
$$

1. Cystopteris fragilis.

2. Cystopteris alpina.

\section{Plate X.}

1. Hymenophyllum Tunbridgense.

2. Cystopteris montana. 
Plate XI.

1. Asplenium Germanicum.

2. Blechnum boreale.

3. Asplenium septentrionale.

Plate XII.

1. Asplenium Ceterach.

2. Asplenium marinum.

3. Asplenium Ruta-muraria.

Plate XIII.

1. Asplenium lanceolatum.

2. Scolopendrium vulgare.

\section{Plate XIV.}

1. Asplenium fontanum.

2. Asplenium Adiantumnigrum.

Plate XV.

Adiantum Capillus-Veneris.

$$
\text { Plate XVI. }
$$

1. Hymenophyllum Wilsoni.

2. Trichomanes radicans. 


\section{BRITISH FERNS.}

\section{CHAPTER I.}

\section{INTRODUCTION,}

Ir is a sign of the good taste of the present generation that fine-foliaged plants have become such general favourites. Gaudy colouring and plentiful blossoms are no longer the sole passports to the garden and the conservatory; elegance of form and grace of contour are fully as much esteemed as the utmost variety and richness of tints, and consequently the Fern family is high in favour everywhere. Builders are now continually applied to to erect fern-houses: one man alone built seventy such houses during one year in the neighbourhood of London. The nurserymen are diligent in cultivating ferns, and offer whole ranges of them to their customers, - beautiful varieties, suited some for the fernery, some for the cool greenhouse, some for the hothouse. Wardian cases bring these popular plants within the reach of every one who has even a small room to 
live in. Enclosed in these cases, the ferns flourish as luxuriantly in the heart of London or Manchester as in the free country. When we write of ferns, therefore, we address not only the gifted possessors of hothouses and conservatories, but those who cultivate their own little plot of garden ground; those who ramble at large in the woods in search of such treasures; and last, but not least, the many who, amidst mercantile pursuits and pressing business, regard the green inhabitants of the Wardian case as an oasis in the desert, their one link to the green fields and early country home.

The true botanist naturally loves ferns the best in their wild habitat. He seeks them amid the crumbling remains of castle and monastery, and as he recognizes the coveted fronds upon the broken arch and the mouldering tower, he feels, with Orwell,-

\section{"And fern and lichen doing Their work of graceful ruin ;"}

or he penetrates the tangled woods, perhaps in the mysterious combes of Devonshire and Somersetshire, or the equally attractive dales of Westmoreland, Yorkshire, and Durham, and he gathers ferns from the treestumps and from the shady nook; or finds them on the river's margin or beneath dripping rock, where those at Guy's Cliff are described as growing :-

"Drip, drip, drip,

In that cool and shady cave,

From the basin in which the moss and fern

Their crumpled edges lave.

Roofed by the living rock

That arches over-head,

Ever by night, and ever by day,

Trickles that crystal thread. 
Ever in summer's heat-

Ever in winter's cold-

Ever in spring's young verdure-

Ever in autumn's gold-

Welling up from its secret urn,

Purling its wreath of nodding fern,

Pure and cool to the thirsty lip,

Ages have echoed that ceaseless drip."

Wander where you will in the open country, you are sure of finding ferns. If it be a chalky soil or a very flat district, you may only find a few common sorts; but if you have access to woods and hills, old walls and rocks, especially if the rocks be near the sea, a great number of species will reward your search. Botanists living in the country enjoy the privilege of observing ferns in their natural habitat all the year round, but those who reside in town only enjoy that privilege for a brief period, and at rare intervals. But these may obviate such disadvantages by bringing plants home, and domesticating them in a Wardian case; thus they can observe their structure and growth even more accurately than the country botanist, and become thoroughly acquainted with their every peculiarity.

Fern-lovers, whether they regard ferns scientifically, grouping them with their natural surroundings in wellcontrived artificial ferneries, or cherishing them in conservatories and Wardian cases, must be lovers of nature ; and as to love nature is to love God's work, and to study nature is to observe the mind of God, such love and such study must exercise an ennobling and purifying effect on the human soul.

All plants are divided into certain groups.

1st. Exogens, or such as increase their stem by external addition. To this class belong all forest trees 
whose age is indicated by concentric rings of growth, and also most flowering plants.

2nd. Endogens, or such as increase their stems by the deposit of fresh substance from within. This group includes many trees, as the palms, and flowers, as the lily tribe and grasses.

3rd. Acrogens, or such as increase by a deposit from the base of the leaves or fronds at the summit. This includes the ferns and mosses. And

4th. Thallogens, or such as increase by an outspread membrane, or thallus. This includes the lichens, algæ, and fungi.

Acrogens are either vascular and fern-like, or cellular and moss-like. Ferns may be described scientifically as "plants of vascular structure which produce fruit without preliminary flowers."

In their affinities, ferns are connected the most closely with flowering plants through the Cycad group. In this group, the vascular system is developed in much the same degree as in the ferns; the leaves are pinnate like the fronds of ferns, and are rolled in youth in the style which in ferns is called the vernation. The cycads have naked ovules bordering their contracted leaves, so as to create a further resemblance between such leaves and the altered fronds of the Osmunda and Lunaria.

Another system of dividing is into two classes-Phænogams, or flowering-plants, and Cryptogams, or flowerless plants. Ferns rank as the highest order of cryptogams. They are a very numerous family, and of very ancient descent. The genera now known are 192 in number, and contain 2040 species. Some of these, as the Norfolk Island Tree-fern, attain a stature of twenty feet; while others, as our Filmy-ferns, are scarcely an inch in height. 
Ferns abound in a fossil state in the coal-measures; magnificent trees belonging to this family, or closely allied to it, are found continually in our coal-pits, and many a rude block of coal or ironstone is adorned by delicate tracery stamped upon it incalculable ages past by the feathery frond of a delicate fern. Ninety-eight different species have been determined among coalfossils, twenty-one have been found in oolite rocks, seven in the triassic strata, and one in the chalk. 


\section{CHAPTER II.}

\section{STRUCTURE.}

A FERN is a flowerless plant of vascular tissue, its trunk, when it possesses one, increasing from the summit, and its seeds or spores germinating from no particular point. This description renders it easy for any botanist to recognize a member of the fern-family, but to general observers vascular tissue and acotyledonous spores convey no obvious notion of the appearance; they must, therefore, turn their notice to the under-side of the fronds or leaves of the plant under consideration, and if they find dusty patches dotting the surface, they may at once conclude that the plant is a fern.

A fern has four parts, each liable to variations and modifications: they are these,--1st, the root; 2nd, the caudex; 3rd, the frond; 4 th, the fructification.

The root of a fern consists of fibres. These are sometimes placed at short intervals upon the creeping caudex, sometimes singly, or in pairs, and sometimes in clusters, or they are situated in more or less dense tufts amid the remains of old fronds near the base of an erect caudex, forming an immense mass of roots, and penetrating the ground to a considerable distance. In some cases these roots are simple, in others they are branched, once, 
twice, or several times; sometimes they are of tender texture, sometimes very wiry, and often in young plants clothed with hairs. The points of the roots and rootlets represent the mouths of the plant, and imbibe moisture for its nourishment.

The caudex or stem is of various character, creeping or ascending. Mr. Newman draws a distinction between two kinds of creeping caudex, the one that terminates in a frond, and the one that does not; calling the first a caudex, and the second a rhizome; but other writers of equal celebrity do not require this distinction, so we need only make one division in the character of the caudex, that of the creeping and erect ones. The creeping caudex extends itself either upon or beneath the surface of the ground, soon becoming twisted and meandering in its manner of growth, and sending out branches in the style of an underground stem, it puts out single roots or clusters of roots at intervals, and throws up young fronds from the superior surface; the creeping caudex is generally more or less clothed with scales. Creeping ferns are very easy of propagation, for any rooted branch is capable of living as a separate plant. The caudex of the Polypodium vulgare creeps on the surface of the soil, that of the P. Dryopteris, Phegopteris, and Robertianum creep beneath the soil. An erect candex increases from the summit, and in tropical climes attains a height of twenty, thirty, or even forty feet. In British ferns this is never the case : the erect caudex has merely a tufted appearance; in many instances it throws out its fronds from its circumference, and each bending outwards with a graceful curve, those ferny crowns are formed which lovers of the beautiful so greatly delight in. In a few species, as the Osmunda 
regalis and Asplenium Filix-fomina, the caudex rises to some extent above the ground, attaining, in old plants of the Osmunda, the height of one or even two feet. The erect caudex sends out abundant roots from its base, and fronds from its summit.

The fronds of ferns are their most showy and attractive feature; they consist of a stipes or stem, the upper part of which is called the rachis, of a leafy part traversed by veins, and often clothed with scales and glands. The fronds of ferns are analogous to the leaves of plants, issuing from the caudex as the leaves do from the branch; but as they differ from simple leaves in that they bear the fruit upon their under surface, it is well that they should have a distinguishing denomination, so we call them fronds.

When first the fronds rise above the surface of the earth, they are curled up in a very curious manner. In most ferns every part is rolled inwards, each part coiled in towards the axis of development, and the whole leafy part forming a ball; the stem is also curled in, and as it uncurls it forms a loop like the head of a crosier; this kind of vernation is called circinate. We have only two genera which differ from the circinate mode of vernation, the Botrychium and Ophioglossum, and their fronds are folded together in a straight manner, as a laundress might fold linen. There are some interesting variations in the habits of the circinate ferns. The most compound species generally put forth their fronds first, and it is in this stage that they won the admiration of the observant author of 'David Elginbrod :' "All about in shady places the ferns were busy untucking themselves from their grave-clothes, unrolling their mysterious coils of life, adding continually to the hidden growth as they 
unfolded the visible." Each little part of these compound ferns is coiled in, the little branchlets in their coils, the main frond in its coil. Thus, at the end of April, the Osmunda regalis, Nephrodium comulum, dilatatum, and collinum will put forth tender balls and crosiers; a little later, and Aspidium angulare, Nephrodium spinulosum, Thelypteris, Cystopteris fragilis, and Asplenium Filix-foemina will appear; later again, Aspidium aculeatum, Nephrodium uliginosum, rigidum, Oreopteris, Polypodium Robertianum and Phegopteris, and the Scolopendrium will look forth; but June will have commenced before Nephrodium cristatum, Polypodium vulgare, and Pteris aquilina will have made their appearance. The main stem uncoils first, hence the crosier form; then the branches or pinnæ uncoil, and then the leaflets or pinnules; the lobes unfold the last. In the fully developed frond each part is open to examination. First we have the stipes, or stem, except in the few instances where the frond is sessile or stemless, the leafy part springing at once from the caudex and the leaf-like portion of the frond : it is generally clothed at the base with chaffy scales, which are supposed to be torn fragments of the outer skin which invested the stem in its early infancy; sometimes these scales are numerous and cover not only the stem but the rachis, sometimes they are few in number, found only near the base of the stem. That portion of the stem traversing the leafy part of the frond is technically called the rachis. The structure of a fern-stem is very curious : it has a kind of tissue peculiar to itself, called scalariform, because of its resemblance to a ladder. Different species have their tissue in different modifications of form. In the stem of Nephrodium Filix-mas there is an external circle of 
woody tissue surrounding the mass of cellular tissue which fills the centre of the stem. In this cellular tissue are imbedded seven bundles of vascular tissue, rounded, of different sizes, and placed near the woody border. In Nephrodium Thelypteris there are only two such bundles, Polypodium vulgare has four, Polypodium Phegopteris only two, and Asplenium Ruta-muraria has but one. Some of these bundles of tissue are round, some oval, some oblong, and some crescent-shaped. The outer circle of woody tissue varies in colour and thickness. Sections of stems show these vascular bundles now as the steps of a ladder, now as a spread-eagle, now as an oak-tree; their number and shape vary at different elevations in the same stem. This structure is discernible in the fossil ferns. The leafy portion of the frond is either simple or compound. When formed of one entire leaf, as in the hart's-tongue, it is simple; when it is divided nearly, but not quite, as far as the rachis, it is pinnatifid; when divided quite to the rachis, it is pinnate. It is compound when the rachis is furnished with branches, each of which is called a secondary rachis; the branches traversed by the secondary rachis are pinnce, as are also the leaflets of a simple pinnate frond, and the leaflets bordering the secondary rachis are pinnules:-when a frond is thus divided, it is called bipinnate; when the pinnules are divided into leaflets, the frond is tripinnate. The character of the divisions of the fronds is an important point of distinction. The outline of the frond varies greatly; we generally consider its outline exclusive of the naked part of the stem. Many ferns have lance-shaped fronds, broadest in the central part, and narrowing to a point at the summit, narrowing also in a less degree towards the base, so as 
to resemble in form a lance-head. Others have triangular fronds generally drawn out to a very acute angle at the summit. Others, again, have oval fronds, or they are tongue-shaped, like the Scolopendrium. In foreign forms some are even round or crescent-shaped. The venation is a very important characteristic in ferns : in some species the veins are simply branched, in some the branches cross one another so as to form a network; they are composed of elongated cellular tissue, and of them the receptacles are formed. The fronds of ferns vary in size from one or two inches to five or six feet in length, and from one inch to two feet in breadth. The fronds are occasionally dotted over with glands, often sweet-scented, or they are covered with hairs both on the rachis and the leafy part; in some foreign species a coloured powder is also present, freely scattered on the under part of the frond.

The fructification of ferns includes the receptacle, spore-cases, and spores. The receptacle is formed of the substance of the veins. The spore-cases Dr. Lindley considers as "minute leaves having the same gyrate mode of development as the ordinary fronds of the tribe, their stalk being the petiole, their annulus the midrib, and themselves the laminæ, the edges of which are united." The foot-stalk of the spore-cases is extended round them in the form of a ring, the elasticity of which causes them to burst when ripe. Some species have the spore-cases sessile and without the ring, and in such cases are formed of regular valves. The presence or absence of the ring causes the fern-family to be divided into two groups, annulate and exannulate. Of the annulate ferns a great number have the fructification on the back of the frond, in which cases it is called 
dorsal; others have it protruded from the margin of the frond, when it is called marginal. In all the dorsiferous ferns the spore-cases are connected together into groups called sori. The forms of these groups decide the genus of the fern, as round for the Polypody, narrow for the Asplenium, linear for the Blechnum, etc. In Hymenophyllum and Trichomanes, the fructification is marginal, and the receptacle is formed of the point of the vein protruded beyond the frond. The genera Osmunda, Ophioglossum, and Botrychium belong to the exannulate division; they have the spore-cases collected upon the sides or surface of contracted fronds, and they are composed of two valves. When the spore-cases spring from beneath the outer membrane of the frond, the cuticle is pushed up into a kind of enwrapping membrane, called an indusium or involucre, and on this account certain groups are named indusiate or non-indusiate. The polypodies are without cover; they are called nonindusiate; while all the families in which the involucre is present are called indusiate. The involucre may be described as "a plane or cup-shaped membrane, proluced from the receptacle of each sorus; when produced from the centre it is central, from one side lateral, and when attached all round the base it is calyciform. When central, it is usually orbicular, with its margin depressed and free all round; when lateral, it is reniform, oval, oblong, or linear; when calyciform, it is entire and globose, and opens after a time with a laciniated margin." Sometimes the margins of the fronds are changed in texture, and converted into a membranous involucre, with which the original involucre unites, and together they form a cyst; or the whole of the sori of each segment are enclosed within a general involucre, 
which is formed of the turned-back margin of fertile contracted fronds.

The spores are extremely minute, roundish in form, crowded into their case without any order of arrangement. The forms of seed afford another distinction by which the leading groups of plants are distinguished. The exogens, or outside-growers, have seeds composed of two cotyledons, between which the embryo is disposed, consisting of the radicle, or rooting-point, and the plumule, or growing-point. The endogens, or insidegrowers, have but one cotyledon, but the points of growth and rooting are clearly determined. The acrogens, or summit-growers, have no cotyledons and no determinate point of growth or rooting; they germinate indiscriminately from any point.

A fern-spore consists of mere cellular tissue. The first change which the spore undergoes is the bursting of the outer covering, and the protrusion of the delicate inner membrane. After a short period this membrane divides, and produces a thallus of two cells. The second cell produces another cell, and so on until five or six are formed. Sonn after the production of the second cell chlorophyll appears, and the plant assumes the form of a Liverwort. From one of the cells root-fibres diverge, and strike down firmly into the ground. Presently new fronds arise, each one partaking more and more of the parent form, and the rudimentary thallus-like frond disappears.

Ferns are the most highly-developed of acrogenous plants. In the algæ and fungi the whole plant consists of cellular tissue, but in the fern group both woody matter and vascular tissue are found. It is principally in the caudex that the woody matter is found, and it 
consists almost exclusively of large scalariform or dotted ducts imbedded in hard plates of tissue, which assume an interrupted wavy appearance, and occasionally, as Mr. Brown tells, form complete tubes. The fronds also are furnished with annular ducts in the vascular tissue of their stems and rachis. 


\section{CHAPTER III.}

\section{PROPAGATION.}

The natural system of propagation for ferns, as well as for other plants, is by the seeds or spores. When care is used, this is not difficult, and Mr. Lowe furnishes us with every instruction that we can require to ensure success. He directs that a flat dish or saucer should be filled with the usual drainage of broken crocks to within one inch of the top, then sphagnum moss, in a perfectly dry state, should be taken, and broken into small pieces by rubbing between the hands, and a layer of the broken moss deposited upon the drainage; that a mixture should be made, composed of equal parts of loam, leaf-mould, silver sand, and broken sphagnum, and the saucer filled with it to the top. Then the pan or saucer should be watered and left to evaporate for some hours. Then the spores may be scattered over the surface of the earth, and the air must be quickly excluded by covering with a hand-glass, and packing wet sphagnum tightly round the edge. It will not be necessary to repeat the watering for a considerable length of time. Care should be taken to select a fresh mature frond to furnish the spores.

The time required for germination varies in different 
species, and under different states of heat and moisture, but it is not a matter of such long patience as is often supposed. Some remain several months before they make their green scales, and some produce them with comparative rapidity. Gymnogramme leptophylla, being more or less an annual fern, requires to be continually raised from spores, and it germinates with great ease and rapidity; it will even sow itself and spring up spontaneously in neighbouring pots in the greenhouse or among the mossy undergrowth in a Wardian case. Pteris tremula and serratula have the same obliging tendency to multiply themselves. Loudon relates facts regarding the propagation and development of cultivated ferns which have come under his own observation. Specimens of Gymnogramme tartarea were brought from Jamaica, and the spores carefully distributed over a prepared vessel, on July 10, 1817. The spores germinated, passed through their Liverwort-like stage, put up true fronds, and produced spores again by August, 1818, and by September, 1819, a series of grandchildren had ripened spores for another seed-time; thus, each generation required thirteen months for full development. The spores of ferns, being so extremely minute and delicate, are of course subject to all the dangers that threaten the life of other seeds, and to some peculiar to themselves; in fact, it is a matter of surprise to all who know the extreme care required in raising seedling plants under cultivation that any such should arrive at maturity in their native localities. This can only be accounted for by considering the immense number of spores produced by each plant, allowing thousands and tens of thousands to perish for want of suitable soil and shelter, for every spore that reaches perfection in its development. When the seed- 
lings have passed the early stage and attained to the dignity of a third frond, it is time to pot them off, and this is a most careful and delicate operation. When any small stones have been left among the mixed earth, a seedling fern will probably be adhering to each of such stones; these are the most easy to manage, for you can readily lift the stone and the young fern attached to it, and plunge both in a tiny pot, covering with soil to the foot of the fronds. Other seedlings are treated similarly, but, if they are crowded together, there will be great difficulty in separating them without wounding the tender fronds.

There is a rougher way of propagating hardy ferns by spores. Small pieces of sandstone or of brick are placed in a damp shady place; these are moistened, sprinkled with spores, and placed under a hand-glass. Many good ferns have been raised thus. Germination takes place rapidly when the spores are sown in small pots and the pots plunged in water, bell glasses being fitted just within the pots. The moisture continually ascending through the drainage and compost, and confined by the glass, brings forward the development rapidly. Another method of propagation is by buds, but this can only be practised in the cases of such species as are viviparous.

Asplenium bulbiferum, a free-growing, half-hardy fern, familiar in our greenhouses and Wardian cases, is generally adorned with a rising family; sprouting buds being situated upon most of the fronds, and often three or four upon the same frond. These infant plants are easily transferred to a pot, and require but little care to nurse them into flourishing plants. There is a bulbiferous Cystopteris, a native of Brazil, which produces buds from its under surface, which are very easily removed and planted out. Woodwardia radicans is perhaps the 
most remarkable of those cultivated in our hothouses for this peculiarity. Itself attaining a height of from five to six feet, the buds upon its fronds develop into plants bearing clusters of fronds a foot in length ; such flourishing plants must readily form a new colony.

The easiest and most rapid way of propagation is by division of the caudex, but this refers chiefly to those species where the caudex is creeping. Such ferns as Polypodium Phegopteris, Dryopteris, and Robertianum are easily increased thus; the foreign allies of the Struthiopteris and Nephrolepis groups are equally suited for division ; in fact, Mr. Lowe tells us that a well-established plant of the last-named genus, placed in a half-peck flowerpot, will yield hundreds of plants in a few months, provided the creeping caudex be well pegged down. Ferns with an erect caudex increase much more slowly; but, even here, the caudex not unfrequently puts up a branch or secondary tuft, which produces its crown of fronds, and forms a new plant for next year.

All hardy ferns that increase by division of the caudex, should be divided just before they begin to grow ; if the operation be performed later, the first set of fronds are sure to perish.

In dividing a fern with tufted and branched caudex, take the plant up carefully, loosening it so thoroughly about the root that there can be no need to lift it by the fronds; shake off the soil, then pass a knife between each crown, and carefully disentangle the roots from those belonging to the other divisions. Shade the new plants from the sun for a few days. 


\section{CHAPTER IV.}

\section{CULTIVATION IN FERNERIES.}

THERE are various ways of cultivating ferns, and various classes of ferns suitable for cultivation; we shall therefore divide the methods and the classes into four parts -1st, Cultivation in the open fernery; 2nd, Cultivation in the Wardian case ; 3rd, Cultivation in the cool greenhouse; 4th, Cultivation under stove heat.

The fernery should be placed in a retired situation, sheltered alike from sun and wind; it should be formed by throwing up a mound of earth, and facing it with blocks of stone and tree-stumps; or it might be made in imitation of a miniature valley, two rocky banks with a walk between. In either case one bank should face the south and the other the north. Having secured a good elevation, and built in plenty of rocky inequalities we must secure a good supply of suitable compost in the spaces between the blocks. The compost must be formed of vegetable mould, peat earth, silver and other sand, and bog-moss in the following proportions as prescribed in the 'Cottage Gardener's Magazine :' - "Vegetable or leaf-mould, one or two years old, one-third; fibrous peat, one-third; bog-moss, finely chopped, onethird, with as much silver sand as will give it a whitish 
silvery appearance." In this rich light open compost the roots of the ferns run freely, and the caudices spread in all directions at their own wild will. Where good stones are difficult of attainment for the rock-work, scoriæ will answer the same purpose, but the appearance is less pleasing. It is highly desirable to obtain mossy stones, as they best imitate natural scenery.

On the side of the rock-work facing the north near the base, such species should be planted as require moisture, and higher up the bank those should be placed to whom shade is the principal desideratum. A flat bed at the foot of the north bank would suit the Osmunda regalis and the Nephrodium Thelypteris the best. On the south slope the denizens of the common hedgebank will grow, - the common Polypody, various species of Aspidium and Nephrodium, the Asplenium Trichomanes and Adiantum-nigrum; and here, if anywhere, the $A s$ plenium Ruta-muraria will flourish. Where the species requires peculiar soil, it can be put in with it. The dead fronds should be allowed to remain through winter to protect the roots from the frost; in the spring they should be carefully removed, fresh soil added, and the neatness of the fernery thus ensured.

If a more fanciful form for the fernery be preferred, it may be made in a circular shape, an opening being left through the bank to enter within the circle. River stones or flints may be built in rows round the mound within and without, so as to form miniature terraces. Common earth, even clay, will do for the basis of the mound, so that a sufficient depth of suitable compost for the roots of the ferns be superimposed. On the flat ground in the centre the marsh species will flourish well; the rest may be planted according to their preferences 
for moisture, shade, or expcsure. Ferneries thus formed are objects of great beauty and interest, and are ever the most popular resorts in the grounds.

But if a well-constructed fernery is beyond our reach, that is no reason why we should be destitute of ferns. These favourite plants may be grown in the most exposed situations, and in the most closed-in valleys, in the smoke of towns, and where the winds prevail; only in the latter case they must have the protection of the glass cover. Where the garden plot is too small to allow space for a fernery, they can be very successfully grown in pots, the same compost being used, or they will flourish in the flower-bed along with other plants.

Most of our native ferns are suitable for the open fernery, and their individual peculiarities and requirements are treated of in the systematic part of this work; in suggesting, therefore, plants for the open fernery, it is only requisite at present to describe the foreign species of hardy ferns which are in request among our ferngrowers.

Polypodium hexagonopterum. Winged Polypody. This is a handsome fern, with fronds half a yard high, triangular, bipinnate, and sessile. The pinnules are oblong and indented, and the whole plant thickly covered with hairs. The sori are round and marginal; the caudex creeping. It is a native of North America.

Struthiopteris Germanica. German Ostrich-fern. Caudex widely creeping; fronds pinnate; leaflets pointed; height of barren fronds 3 or 4 feet. Fertile fronds erect, arranged in a cluster in the centre. The barren fronds are of a vivid pale-green tint, shading to a lighter hue at the base; the caudex spreads widely, throwing up fresh clusters of fronds at a distance of several feet. This 
fern is especially desirable, for it grows freely and increases rapidly. It is a native of Germany.

Struthiopteris Pennsylvanica. Pennsylvanian Ostrichfern. Caudex creeping; fronds 3 feet high, pinnate; leaflets blunt; fertile fronds 1 foot high, contracted, central. A native of Pennsylvania.

Woodsia mollis. Downy Woodsia. Caudex tufted; fronds lanceolate, bipinnate, and hairy; pinnæ oblong and blunt; leaflets oblong and sessile, notched at the margin; height 12 to 18 inches, light green in colour. This fern suits well the south exposure of a rockery, and is becoming a favourite in English gardens.

Woodsia obtusa. Blunt Woodsia. Caudex tufted; fronds lanceolate, hairy ; pinnæ triangular ; leaflets longoblong, notched. A dwarf species, very pretty, and well suited for the fernery.

Aspidium acrostichoides. Acrostichum-like Shield-fern. Caudex tufted; fronds 2 feet high, lance-shaped, pinnate; leaflets narrow, stalked, and with long hairs. Sori on the upper part of the frond, which is contracted; stems and caudex scaly. A very pleasing fern, noble and spear-like. A native of North A merica. Evergreen. Aspidium marginale. Bordered Shield-fern. Caudex tufted; fronds lanceolate, bipinnate, pinnæ oblong pointed; leaflets ovate, notched; stems chaffy. This is a peculiar and beautiful fern, its most notable characteristic being the line of pure white involucres which border the edge of the frond. It is a native of North America and Canada, and grows in magnificent crowns.

Aspidium setosum. Bristly Shield-fern. Caudex tufted; fronds bipinnate, ovate, pointed, 2 or 3 feet high; pinnules oblong, acute, eared, and fringed with stiff hairs. A native of Japan. 
Nephrodium decurrens. Decurrent Kidney-fern. Caudex tufted; fronds lance-shaped, pinnate, drooping, a foot high; pinnæ sessile; the rachis winged and chaffy; sori situated at the end of the veins. This is a somewhat tender fern, and flourishes best in a frame or greenhouse, but it will live in the open air if covered with leaves during the winter season. The light green drooping fronds grow in a coronal form, and make a very pleasing object. It is a native of China, and only recently introduced into England.

Nephrodium Goldianum. Goldie's Kidney-fern. Caudex tufted; fronds broadly lance-shaped, twice pinnate; pinnæ lance-shaped, serrated; stems scaly; fronds 2 feet high. A noble fern, imported from North America.

Nephrodium Noveboracensis. New York Kidney-fern. Caudex creeping; fronds very slender, hairy, pinnate; pinnæ lance-shaped, sessile, grows about a foot high. It is easy to increase because of its creeping caudex, and is therefore becoming well known in our ferneries. As its name imports, it is a native of New York.

Nephrodium Sieboldii. Dr. Siebold's Kidney-fern. This fern is of peculiar appearance and easily recognized. Its fronds are long, leathery, once-divided, and of a dull green colour; the leaflets are broad, and have entire margins. Mr. J. Smith calls it podophylla; it grows about a foot high, and is a native of Japan.

Asplenium angustifolium. Narrow-fronded Asplenium. Caudex tufted; fronds pinnate, erect, light green, 18 inches high; pinnæ lanceolate. A native of North America, flourishing well in English ferneries.

Asplenium Michauxi. Michaux's Spleenwort. Caudex creeping; fronds broad, lance-shaped, tripinnate; pinnæ flat and very distant; leaflets deeply serrated. This fern 
is a handsome species, growing to the height of $2 \frac{1}{2}$ feet. It increases rapidly by means of its creeping caudex, dies down in winter and reappears the following spring more luxuriant than ever. It is perfectly hardy, and very pretty, especially the variety with purple stems. It is a native of North America.

Cystopteris bulbifera. Bulb-bearing Bladder-fern. Fronds bipinnate, lanceolate, nearly erect, tapering elegantly to the apex, about a foot high, and bearing towards the top numerous little bulbs, about the size of a pea, which fall off or are easily detached, and reproduce the plant. It is a native of North America, Canada, and the United States.

Cystopteris sempervirens. Evergreen Bladder-fern. Closely resembling Cystopteris fragilis, and considered by Mr. Moore only an evergreen variety of that species.

Blechnum alpinum. Alpine Hard-fern. Barren fronds lance-shaped, erect, pinnate, bright green, 4 inches high ; pinnæ oblong, rounded margins entire. Fertile fronds contracted, pinnate, 6 inches high; pinnæ far apart. Caudex creeping. This fern requires its roots protecting in winter either by a covering of dead leaves or by a hand-glass. It increases rapidly by means of its creeping caudex, and is a pretty dwarf species. It is a native of the hills of Tasmania.

Blechnum crenulata. Notched Hard-fern. Caudex tufted; fronds narrow, lanceolate, pinnate; pinnæ pointed; fertile fronds about 6 inches high; barren ones about 5 inches, all growing together in a dense tuft; stems reddish. Introduced from Chili by Mr. Veitch.

Scolopendrium vulgare, var. undulatum. Waved Hart'stongue. A beautiful and well-known variety, with the 
margin very much waved, almost plaited, quite in the style of a frill or ruffle. It should be grown in peat, and forms a dense cluster of a beautiful pale green and most luxuriant foliage. This is a very variable fern. Sometimes its fronds are forked, sometimes lobed, always plaited, often fringed, now contracted, and now expanded, and endlessly diversified. Mr. Sim, of Foot's Cray, has got a splendid collection of the varieties, - he has a perfect host of Hart's-tongues.

Adiantum pedatum. Bird's-foot Maiden-hair. Fronds situated on long blackish glossy foot-stalks, crowded together, pinnate ; pinnules thin, oblong, obtuse, lobed on the upper margin, crescent-shaped. This is the only entirely hardy Adiantum; it is a native of North America and North India; it lives very well in an out-door fernery, if its roots be covered with dead leaves in winter; but it certainly grows more luxuriantly in a cool house. It will attain the height of 18 inches in the open air, by 12 inches in breadth. It is much more hardy than our native Maiden-hair.

Woodwardia Virginea. Virginian Woodwardia. Cau. dex creeping; fronds pinnate, ovate-lanceolate, shining; pinnæ lanceolate, pinnatifid, stalked, segments ovate, entire. A Virginian species.

Woodwardia areolata. Divided Woodwardia. Caudex creeping; barren fronds pinnatifid, glossy; segments ovate, lanceolate, serrated; fertile fronds erect and pinnatifid, segments linear, pointed, and narrow. A handsome fern; the fertile fronds measuring 15 inches, and standing erect in the centre of the group; the barren fronds are situated around the circumference, slightly bending, 12 inches in length, and of a beautful light green. 
Onoclea sensibilis. Sensitive Onoclea. Caudex creeping; barren fronds triangular, glossy, pinnate, of a most beautiful delicate green colour; the pinnæ with lobed margins; fertile fronds bipinnate, contracted, shorter than the barren ones, the leaflets curling over the sporecases. 1 to 2 feet high. This elegant and freely-growing fern is a native of North America; it can bear a fair amount of shade, flourishing well in a wood where the trees do not stand too thick, its caudex creeping freely amongst the leaf-mould. It should not be absent from any good fernery.

Osmunda Claytoniana. Clayton's Osmunda. Fronds bipinnate, those in the centre of the cluster contracted towards the middle by fruitful pinnæ; the centre fronds stand erect, thus displaying the curious contraction of the pinnules along the middle pirnæe, which give an interrupted appearance to the frond, earning for the fern at one time the name interrupta; the upper pinnæ are as much expanded as the lower ones, and look like feathers waving above the contracted part; around the circumference of the group the long lance-shaped, barren fronds are ranged, bending outwards in a variety of graceful arches. They are of a beautiful vivid green colour, and render the fern a very favourite one.

Osmunda cinnamomea. Cinnamon-coloured Osmunda. The fertile fronds rise perpendicularly in the centre of a circle formed by the gracefully drooping barren ones; the fertile fronds are bipinnate, and covered with dense rust-coloured hairs, - thus they look like a group of erect reddish-brown fronds. The barren fronds are narrow, only measuring about 7 inches across in the widest part, and narrow off to a fine point at the apex, in height they measure above 30 inches; they have 
rusty hairs on their stems. The fertile stems are covered with dense white wool. This fern is found both in North and South America, and in the East and West Indies.

Osmunda gracilis. Slender Osmunda. Smaller, with large leaflets of delicate texture; it grows as high as 2 feet, and is of fragile appearance though quite hardy.

Osmunda spectabilis. Showy Osmunda. Resembling our native species, but not more than half its size; it has a purplish tinge in youth.

Osmunda punctiloba. Dotted Osmunda. Graceful and slender, much divided, and with minute leaflets, in general appearance resembling the Lady-fern. A native of the United States and Canada. 


\section{CHAPTER IV. \\ CULTIVATION IN WARDIAN CASES AND \\ GREENHOUSES.}

WHEN first Mr. Ward introduced among us his most happy invention of glazed cases for growing ferns, he announced the reasons upon which he had based his theory for their construction.

His first desideratum was protection from the smoke and dust with which the air of towns is laden, which smoke and dust adhere to the fronds of the ferns and obstruct their breathing-organs, as similar impediments affect the lungs of the human race.

His second desideratum was protection from the extremes of heat and cold. The experiments of Sir C. Blagden and others having demonstrated that both animals and vegetables will endure without injury the extremes of heat and cold provided the atmosphere be undisturbed, the securing of an atmosphere of perfect stillness is equivalent to the securing one of more equal. temperature. The validity of this argument in the matter in question is proved by the fact that the Hymenophyllums and Trichomanes have borne exposure to the sun, and Asplenium molle, Phœnix dactyliferus, and Dendrobium pulchellum have lived without heat, under the protection of the Wardian case. 
His third desideratum was to prevent the escape of moisture, and so ensure a continually damp atmosphere to the ferns.

His fourth desideratum was to secure such an amount of light and solar heat as should bring the ferns to their full development. This is attained according to the size of the species of fern and the size of the case employed. When due proportions are observed, the ferns grow luxuriantly, and ripen their spores to perfection.

For the convenience of the many desiring new ferncases, we quote the directions for the building of one given recently in the 'Journal of Horticulture.'

"We require a planed, well-seasoned deal board, 21 inches by 12 inches, and $1 \frac{1}{2}$ inch thick; also two other planed deal boards 12 inches by 10 inches, of the same thickness. These latter are firmly mortised perpendicularly into the ends of the former, 1 inch from the edge. Grooves $\frac{1}{4}$ inch by $\frac{3}{8}$ inch are, in each case, cut in the inner side of the uprights, and carried in a right line along the base pieces $\frac{1}{2}$ inch from their edges. This framework may be covered all over with oil paint, three coats in thickness; or, if preferred, it can be coloured with oak-stain, and thoroughly varnished thrice with shellac dissolved in spirits of wine. When dry, the grooves are filled with white or red-lead putty, and glazed with $\frac{1}{8}$ inch sheet glass. The putty having set, the joints can be varnished, and a frame of deal moulding screwed on the top, the screws passing downwards into the uprights. Ornamental finials of turned deal are fixed by wire pegs to the upper rail at its four corners. A sheet of glass lies loosely on the top of the moulded rail. Thus with the addition of a few perforations in the vertical pieces above soil-level, the ventilation necessary can be 
arranged to a nicety. The fernery is now complete, and when filled and fitted with back scene,forms an interesting ornament. A few pieces of tile should be spread at the bottom and then broken sandstone, and charcoal, and bog-earth."

Having prepared our fern-case with a stratum of drainage, and then a compost of leaf-mould, peat-earth, silver-sand, and sphagnum, we proceed to arrange our miniature landscape of pieces of rock, gypsum, crystals, etc., or leave the soil plain, seeking no other beauty than that of the elegant form and verdure of the ferns.

Such a fernery as we have described will hold about eighteen ferns. A few mosses for undergrowth are very desirable, as they add to the beauty, and prevent evaporation. One or two lichens, as the Scarlet Cup, etc., will flourish well, and secure a pleasing effect.

Mr. W. F. French, of Bristol, prepares very pretty fern-glasses, arranging within them Lilliputian rocks and ruins. They are to be had at the flower shops in Covent Garden; and, though they do not look by any means beautiful when unfurnished, they have an excellent effect with the full complement of mosses, lichens, and ferns. The best place for such cases is in a window to the north, and twice a week in the summer the glass should be removed and wiped dry, a little rain-water being administered occasionally to keep up the moisture. These fern-cases make very elegant drawing-room ornaments. All the small hardy and half-hardy ferns are well adapted for the Wardian cases, as are also many of the Lycopodiums and all the mosses.

Ferns are fully as welcome in our greenhouses as elsewhere, contrasting their elegant form and perpetual verdure with the brilliant colour of Camellias, Gera- 
niums, and other exotics. In a greenhouse of moderate temperature, kept only a few degrees above freezingpoint in winter, and left to nature's means of heating in summer, many rare and beautiful ferns will flourish luxuriantly. Another claim that the ferns may plead in seeking a place in the greenhouse is that while the winter refugees crowd the house, the fronds of the ferns are dying down, and they are going into their dormant state, so they may be stowed away under the stages or in any corner, so that they are kept reasonably warm; then, when the fine May weather tempts out shoals of half-hardy plants to adorn the garden, the ferns are welcome on the shelves, and their graceful fronds improving in size and beauty with each day's light, become continually more welcome in the partially-deserted house.

The compost in which to pot ferns should be composed of fibry peat, leaf-mould, and silver-sand, some species requiring an admixture of broken mortar from old buildings, some needing the addition of charcoal, and some again of the sphagnum moss.

The potting should take place in spring, when the young fronds are beginning to push forth. Let the pots be well washed, if old; if new, well soaked. Fill a third part of the pot with potsherds, the first broken into large pieces, the rest as small as peas; then lay a stratum of broken sandstone and of charcoal broken the size of filberts; then fill to the top with the compost. Let all the potting be done at once, and no plant kept longer in a cold draught of air than is absolutely necessary. At the time of potting remove all decayed or decaying fronds and dead roots. Do not fill the pots to the brim, but leave room enough to hold sufficient water thoroughly to wet the ball of earth 
retained round the root of the plant. Before they are returned to the greenhouse they should be well watered. Great care is required in watering greenhouse ferns; they must never be allowed to become dry, except on the surface, yet only a little must be given at once. Syringe them well in hot weather, taking care always to use rain-water.

Of course air must be admitted daily and all day; at night also in summer. A covering of Shaw's tiffany will be an advantage for hot sunshine.

Greenhouse-ferns are subject to some diseases, or rather to the ravages of some insects. The syringing will prevent the scale; but if it has appeared before the means of prevention have been taken, recourse must be had to means of cure. Tobacco-wash is the best remedy for this, and if the vermin are, very abundant the most infested fronds must be cut off and burned. The thrips may be kept down with tobacco-smoke, but if it gets ahead the ferns must be washed with tobaccowater and sulphur. Fumigation must be resorted to when mealy-bug appears. Several species of Adiantum flourish in our greenhouses, including our native species and the bird-footed one, described as a hardy fern.

The most attractive greenhouse ferns are as follows:-

The genus Drynaria is named from words signifying a tree; it is allied to Polypodium, having no involucre, and the veins being crooked. The species live on woods, and often grow parasitically on the bark of trees.

Drynaria Billardieri. Billardière's Drynaria. Caudex widely creeping, fronds simple and pinnate. Sori large. A New Zealand species, very desirable in the greenhouse for its rapid growth; it can be trained to cover damp walls or rock-work, or placed in pendent haskets. 
Drynaria pustulata. Pimpled Drynaria. Fronds seldom a foot long, simple or pinnate; sori in a row, round. A native of New Zealand.

Aspidium furcatum. Forked Shield-fern. This is a wellknown and very handsome fern. Its fronds are thick, full-coloured, and glossy, like the leaves of the Portugal Laurel; on the under-surface they are scattered with round sori. This bold-looking fern is a native of Japan, the Cape, and India; it is an advantage to it to be turned out in the summer.

Aspidium concavum. Concave Shield-fern. Fronds four times pinnate; leaflets ovate, crowded; their margins recurved. A large spreading fern of a rich green colour, and very handsome.

Aspidium ordinatum. Regular Shield-fern. Fronds bipinnate, dark green, with deformed triangular-shaped doubly-serrated leaflets. A handsome fern; its bold fronds plume-like and very beautiful. A native of South America.

Aspidium vestitum. Clothed Shield-fern. Fronds bipinnate, dark green, glossy ; 2 feet in height. There is a viviparous variety of this plant, which bears little clusters of young plants at the apices of the fronds. This and varieties are imported from New Zealand, that great treasure-house of ferns.

Of the many species of Asplenium advertised as halfhardy in the catalogues of nurserymen, we select a few for description.

Asplenium appendiculatum. Fronds tripinnate, rising a foot high, and rooting again at the extreme point; leaflets oval, sharply and deeply serrated at the margin; sori oblong, crowded; caudex creeping slowly; stems scaly and winged. From its habit of rooting, and thus 
forming new plants from the point of the frond, this fern is considered a variety of Asplenium bulbiferum. It is a Tasmanian species.

Asplenium Brownii. Brown's Spleenwort. Fronds partly tripinnate, lance-shaped, dark green, rather drooping, 2 to 3 feet long; pinnæ lance-shaped; leaflets largest next the stem, sharp-pointed, and cut or scalloped at the margin; stems scaly; sori oblong; involucre, inflated; caudex creeping. A native of New South Wales.

Asplenium compressum. Fronds pinnate, leathery in texture, stout; rachis winged, 2 feet high ; pinnæ broad, many of them producing germinating buds or bulbs; caudex ascending.

Asplenium flaccidum. Feeble Spleenwort. Fronds long, lance-shaped, tripinnate, dull green; pinnæ long and linear, producing young plants at the end of the frond and at the points of the leaflets. The drooping habit of this fern makes it suitable for pendent baskets, and it is nearly as often placed in such situations as the next species is. It is a New Zealand species.

Asplenium flabellifolium. Fan-leaved Splecnwort. Fronds linear, growing a foot long, pinnate for a great part of their length, and then becoming merely a naked rachis. At the end of each fully-developed rachis a new plant is produced. This is rather a sweeping than a drooping fern, the fronds hanging over the sides of the basket, and descending to a great distance. It is a native of New Holland, and thoroughly domesticated in our conservatories.

Asplenium obtusatum. Blunt-fronded Spleenwort. Fronds pinnate, erect, rigid, leathery, bright green; stem winged and scaly; pinnæ oblong, blunt, serrated 
at the edge. A dwarf but handsome species, easily increased by division. A native of New Zealand.

Asplenium palmatum (Hemionitis). Palmate Spleenwort. Caudex creeping; fronds simple, divided into five finger-like segments. Dwarf but handsome, seldom exceeding 5 .inches in height. Sometimes the segments are forked one or more times, and thus several varieties are formed. It is brought from the Canary Islands.

Asplenium reclinatum. Drooping Spleenwort. Fronds pinnate, producing young plants at the apex; caudex tufted. A pretty, graceful little fern, growing in the coronal form, and forming an elegant object by the outward drooping of its fronds. A native of the island of St. Helena.

Blechnum cartilagineum. Fleshy Hard-fern. Caudex creeping, thick; fronds pinnate, lance-shaped, 3 feet in length ; pinnæ sharply serrated, dark green ; 8 inches long in the lowest part of the frond, and gradually diminished in size towards the apex. A native of New Holland.

Blechnum triangulare. Triangular Hard-fern. Fronds triangular, pinnate; pinnæ sessile, alternate. Very handsome. A Mexican fern.

Blechnum auriculatum. Eared Hard-fern. Caudex tufted and branching; fronds pinnate, barren ones lanceshaped, fertile ones broader at the base; the pinnæ long, narrow, sharply pointed. Attains a height of nearly 2 feet, and the green is full and of a pleasing tint. A very desirable fern. A native of the Cape of Good Hope.

Blechnum Capense. Cape Hard-fern. Caudex creeping, thick ; barren fronds pinnate, of coarse texture, dark green, 3 feet high; fertile fronds pinnate; pinnæ long 
and narrow, contracted; stems scaly. A bold, handsome species. A native of the Cape, as its name indicates.

Blechnum Magellanicum. Magellan Hard-fern. Caudex erect, thick; barren fronds pinnate, lance-shaped, 2 feet long; fertile fronds pinnate; the pinnæ narrower, contracted, sharp-pointed. This fern may be considered as a dwarf shrubby species, plants having been seen on the Organ mountains of Brazil 4 feet high. It is a native of Tierra del Fuego, and is called from the neighbouring Straits.

Blechnum nudum. Naked Hard-fern. Caudex creeping, many-headed; fronds pinnate; barren ones broadly lance-shaped, of a beautiful dark shining green, $1 \frac{1}{2}$ foot high; fertile one with the pinnæ sickle-shaped, narrow, and sharp-pointed. One of the most effective ferns of this group. A native of Van Diemen's Land.

Many new species of Blechnum have been recently introduced into Britain, some as greenhouse, others as stove ferns. Mr. Standish, of Ascot, and Mr. Lee, of Harnmersmith, show a great variety.

Adiantum assimile. Fronds tripinnate; leafiets rhomboid and somewhat serrated; involucres kidney-shaped. The creeping caudex soon covers the surface of the mould in the pot, and the fronds, freely thrown up on every side, bend in varions graceful forms. It is peculiarly suited for an epergne on a dinner table, and plants destined for that purpose should be placed on a pedestal in the greenhouse, formed by a large inverted pot, so as to allow free scope for the development and drooping of the fronds. It is a native of Australia.

Adiantum scabrum. Silver Maiden-hair. Recently introduced from Chili. A dwarf plant, sprinkled with powder, like some of the Gymnograms. 
Adiantum sulphureum. Sulphur-coloured Maiden-hair. Introduced along with the last-mentioned by Mr. Veitch, and called the Golden Maiden-hair. It grows a foot high, and the sulphur powder is on the under-surface.

The Aspidium group offer a good number of species to the care of the greenhouse, some of them well worthy of notice.

The genus Cassebeera contains some beautiful stove and greenhouse ferns. It is named after Herr Cassebeer, a German botanist, and is closely allied to Pteris. In this genus the spore-cases are placed on the summit of four veins. They are dwarf ferns.

The genus Cheilanthes is named from two Greek words, signifying lip and flower, because of the shape of the involucre: a group of very handsome ferns, never enduring that their fronds should be wetted. They require a compost of sandy peat with charcoal intermixed, and suffer if allowed too much water.

Cheilanthes micromera. Small-parted Cheilanthes. Fronds bipinnate, 9 inches high; pinnules short and narrow, the sterile ones notched on the margin; stems black and scaly; caudex creeping; sori long and narrow. An elegant little fern of a deep milky-green colour. A native of Mexico.

Cheilanthes Micropteris. Small-winged Cheilanthes. Fronds pinnate, hairy, very slender, 6 inches long ; pinnæ small, roundish, crowded; stems smooth, dark brown; caudex creeping. A neat, pretty little fern, also a native of Mexico.

Cheilanthes geraniifolia bears a striking resemblance to the Geranium Robertianum of our hedgebanks; its little fronds are palmate, and the stems brown and wiry. It is especially suitable for a Wardian case. 
Cheilanthes hastata. Halbert-shaped Cassebeera. Better known by its former name of Pteris hastata, a tallergrowing fern, one of the largest of the genus, attaining sometimes a height of two feet. Fronds bipinnate, the lower pinnæ heart-shaped, the upper halbert-shaped; stems dark brown; sori on the margin narrow and continuous. Easily increased by spores. A native of the Cape.

The genus Onychium is so called from the divisions of the fronds resembling a claw, onychion.

Onychium lucidum. Shining Onychium. Caudex creeping; fronds slender, triangular; fertile fronds 15 or 16 inches long, barren ones 3 or 4 inches shorter; all of a bright green colour, and very finely divided; sori small, but when ripe they nearly cover the under side of the leaflets. A native of Japan, but sufficiently hardy for a greenhouse.

The genus Woodwardia is called after the eminent British botanist Mr. Woodward. Its sori are sunk in the leaf, and covered with hollow involucres, and the veins form a network.

Woodwardia radicans. Rooting Woodwardia. Fronds pinnate, irregular, bright green; pinnæ of various breadth and length, cut at the margin into sharp segments. At the apex of the frond a bulb is formed, which presently puts forth roots from which new plants spring. This is a fine bold fern, growing 3 feet high, the fronds spreading in every direction, and covering a considerable space. It is a native of North America.

The genus Niphobolus is derived from nipholus, covered with snow; because the fronds are covered with short hairs, like snow-crystals; they are very useful in the greenhouse or hothouse to ornament baskets and rock- 
work, on account of their dwarf stature and creeping habit. Under a lens each hair is seen to be a perfect star of crystal-like brilliancy.

Niphobolus Lingua. Tongue-like Niphobolus. Barren fronds long, oval, terminating in a sharp point, simple; fertile fronds rather smaller, and with the edge a little recurved; sori thickly scattered beneath the frond, often confluent; texture of the fronds thick, the veins placed between the upper and under cuticle, and thus hidden, but of wondrous beauty when once the thick covering of the leaf is removed. A native of China.

Niphobolus rupestris. Rock Niphobolus. Caudex creeping; fertile fronds narrow, blunt at the top, 3 inches in height, simple; barren fronds thick, oval, simple, 2 inches high. A native of Australia.

The genus Nothochlana is named from two words, signifying cloak and spurious, because they are destitute of a genuine involucre; it is a lovely group of ferns, rather impatient of moisture on their fronds.

Nothochlana distans. Distant Nothochlana. Caudex creeping; fronds bipinnate, 6 inches long; pinnæ sessile, hairy; pinnules opposite and distant; stems covered with scales; sori on the margin of the fronds. A pretty, delicate fern; a native of New Holland.

Nothochlana lanuginosa. Woolly Nothochlana. Caudex creeping; fronds bipinnate, covered with fine woolly hair, quite brown on the under-side; pinnæ round, except the end one, which is divided into two or three lobes; sori round, and situated at the end of the pinnæ. A Madeira fern.

Nothochlana vestita. Clothed Nothochlana. Fronds bipinnate, 5 inches high; pinræx roundish, crowded; the 
whole plant is densely clothed with hairs; it bears a very cool house, being a North American species.

The genus Davallia is called after M. Davall, a Swiss botanist. Its sori are contained in a cup-shaped hollow. Most of the species are stove-ferns.

Davallia Canariensis. Hare's-foot fern. Caudex creeping, densely leafy and hairy, like a hare's foot; fronds much divided, full green, somewhat triangular in form. A very familiar fern in our conservatories.

Davallia pyxidata. Shining Davallia. Fronds 18 inches high, smooth, tripinnate; caudex erect, thick, plant shrub-like. A native of New Holland.

The genus Gleichenia is named after the German botanist Baron von Gleichen; it contains many beautiful and valuable species.

Gleichenia dicarpa. Two-fruited Gleichenia. Branches forked; little fronds pinnate; pinnæ round, looking; like strings of green beads, about 18 inches high, growing in a dense, bushy cluster; caudex creeping; sori often containing two spore-cases, hence the name. A native of Australia.

Gleichenia flabellata. Fan-shaped Gleichenia. Fronds divided into branches, fan-shaped, each division from 6-9 inches in length, drooping: caudex creeping on the surface. A free-growing and very elegant species, the fronds 4 feet in height.

Gleichenia microphylla. Small-leaved Gleichenia. A tall fern, slender, and bearing the spore-masses on the surface of the frond.

Gleichenia rupestris. Rock Gleichenia. A curious and beautiful fern, the fronds thick, and so much divided and drooping as to be quite feathery, of a light green colour above, and whitish beneath. It is very rare. 
Gleichenia semivestita. Half-clothed Gleichenia. Resembling microphylla, of which it is probably a variety. Its distinguishing feature is the greater hairiness of the stems. It attains a height of about 3 feet.

Gleichenia speluncè. Cave Gleichenia. Very glaucous in colour, and white beneath, perhaps the most beautiful of the family. It grows in caves and dells; it and its brethren are natives of Australia.

Pteris arguta. Sharp-notched Brake. Caudex creeping; fronds spreading, many times divided, triangular in form and of a pale green colour; leaflets bluntly oblong and sharply serrated; stems rich brown, a foot long, the leafy part of the frond measuring two feet. This noble fern requires a great deal of room ; it is a native of Madeira.

Pteris Cretica. Cretan Brake. Fronds pinnate, upwards of a foot high, of a beautiful vivid green; fertile fronds with long narrow pinnæ, those of the barren fronds long, lance-shaped, the lowest pair sometimes forked; stems pale. Found in Crete, China, the East and $\mathrm{W}$ est Indies, and Southern Europe.

Pteris Kingiana. Captain King's Brake. Fronds bipinnate in the lower part, spreading, 2 feet high ; pinnæ long, lance-shaped, sharply serrated, drooping. A Norfolk Island species.

Pteris scaberula. Roughish Brake. Fronds divided into very fine segments, triangular in form, spreading horizontally, and of a beautiful light green colour, 8 or 9 inches high. A perfect little gem, and should be grown near the glass in a greenhouse, and never exposed to cutting draughts. A native of New Zealand.

Pteris serrulata. Finely-serrulated Brake. A small flaccid variety of our wild Brake, with minute leaflets and arching stems. 
Pteris tremula. Shaking Brake. Fronds much divided, 2 feet long, spreading; leaflets narrow and hollowed out at the edges. Very free in its growth, sowing itself on all sides. A native of New Zealand.

Pteris umbrosa. Shading Brake. Fronds bipinnate at the base, and only pinnate towards the apex; pinnæ very long, the fertile ones sometimes measuring 10 inches. A handsome fern, growing to the height of 2 feet, and easily increased both by spores and by division. Brought from New South Wales.

The genus Platyloma is allied to Pteris; its name is derived from platys, broad, and loma, margin, in reference to the broad border of spore-cases upon the undermargin of the frond.

Platylomaatropurpurea. Dark purple Platyloma. Caudex creeping; fronds bipinnate, 10 inches high; pinnæ oval, heart-shaped at the base, narrowing towards the point. Of a purplish-green colour, and very beautiful. A native of North America.

Platyloma cordata. Heart-shaped Piatyloma. Caudex thick, scaly, creeping; fronds bipinnate, delicate, erect, $1 \frac{1}{2}$ foot high ; pinnæ heart-shaped, pointed, of a beautiful light green colour, and hairy; stems light brown. This is a Mexican species, it loses its fronds in winter, and should then have very little water.

Platyloma falcata. Sickle-shaped Platyloma. Caudex creeping; fronds pinnate, lance-shaped, erect, 2 feet high ; pinnæ oblong, pointed, heart-shaped at base, then sickle-shaped, of a dull green colour, and leathery texture; stems scaly. A handsome fern, imported from New Holland.

Platyloma rotundifolia. Round-leaved Platyloma. Caudex creeping; fronds pinnate, reclining, $1 \frac{1}{2}$ foot long; 
pinnæ roundish, stout, dark green; stems covered with brown scales. Very easy of propagation, and well suited to a Wardian case, or for baskets in a conservatury. A native of New Zealand.

Balantium culcitum. Cushion Balantium. Caudex decumbent, slightly creeping, very thick; fronds tripinnate; pinnæ triangular; pinnules deeply toothed, pointed. The name Balantium, signifying purse, is given because of the peculiar form of the sori, which is oblong and opening as if by a lid. It is a native of Madeira, attains a height of 3 feet, and is a very imposing-looking fern.

The genus Cyathea is so called because of its cupshaped involucre. It contains magnificent tree-ferns, 50 feet high, of Palm-like beauty. The species introduced into England are of much smaller dimensions, but sufficiently magnificent.

Cyathea Cunninghami. Cunningham's Cyathea. Stem usually covered with brown roots in the lower part, and with whitish scales in the upper, and surmounted by a noble tuft of tripinnate fronds, 5 or 6 feet in length. Brought from New Zealand, and there attaining a height of from 20 to 25 feet.

C. Smithii. Smith's Cythea. Stems stout, convex, with brown scales. Fronds bi- and tripinnate, bright glossy green. A handsome tree-fern, a native of New Zealand.

Hymenophyllum demissum. Pendent Filmy-fern. This is a New Zealand brother of our minute native Hymenophyllums, and may be considered by them as a veritable giant, for its fronds exceed a foot in length! They are bipinnate, semitransparent, and smooth. This fern should be carefully guarded against sunshine, grown in 
a shallow pan, with thorough drainage, and with porous stone about its roots. It must be well watered at the root and also sprinkled on the fronds, but the water must not be suffered to remain stagnant about it.

Trichomanes reniformis. Kidney-shaped Bristle-fern. This curious and beautiful New Zealand Bristle-fern differs from our native species in the bristle not being developed beyond the point surrounded by the spore-cases. The fronds are simple, kidney-shaped, the stem and leafy part each about 3 inches in length, of a dark green colour, smooth, and semitransparent. The caudex is slender and creeping, like that of our native species.

The genus Todea was named after the Mecklenburg botanist Tode.

Todea Africana. African Todea. Caudex short, thick, erect, approaching in character to that of a tree-fern; fronds bipinnate, erect at first, then arching gracefully, 3 or 4 feet long. It is a native of the Cape of Good Hope.

Todea rivularis. Riverside Todea. Caudex erect, stout; fronds bipinnate, feathery. Closely resembling the last species, though belonging to Australia.

Todea pellucida. Transparent Todea. A dwarf species, resembling in character our native Filmy-ferns. The fronds are semitransparent, much divided, and light green. It grows in the swamps of New Zealand, and when introduced into our greenhouses, it should receive the same treatment as the Hymenophyllums. 


\section{CHAPTER V.}

\section{CULTIVATION IN HOTHOUSES.}

The beautiful fern-houses of Mr. Backhouse, of York, would inspire any one, who had ample means at his command, with the desire of possessing such an object of beauty, and we are not astonished to learn that large numbers are being erected annually, in connection both with botanic and private gardens, and in the grounds of nurserymen.

In erecting such a house, a low site should be selected, in order that a fountain may be secured, and pipes supplied with water without requiring an enormous elevation for the reservoir. Good thick walls of brick or stone will be required, and a well-drained floor. The rockwork must next be raised, and should be formed of masses of freestone or limestone, blocks covered with moss and lichens being preferred if attainable. Treeroots and stumps are not desirable, as they become infested with fungi, and soon rot away. The rock-work should be firmly built, the inner parts filled in with small stones, leaving openings enough to hold sufficient soil for the nourishment of the ferns, and so disposing the large stones as to hide the waterpipes, but not render approach to them impossible in case of accidents. Un- 
dressed flagstones should be laid upon the floor, and the heating-apparatus fixed. The "contributors to the journal of horticulture," in their 'Fern Manual,' a most valuable book, from which we have drawn much information upon stove and greenhouse ferns, suggests that "a four-inch wrought-iron Monro's cannon-boiler will shoot out ample boiling water into the 500 feet of fourinch pipe, which they propose to heat a very large fernhouse with. The roof should be slanted from the two sides of the ridge-tree, and glazed with rough plate-glass, -all the wood work being painted well with white lead and then varnished."

The 'Fern Manual' gives directions for the best compost to be used.- "Soil wherein ferns are to be grown should be of a porous nature, and that is not liable to become adhesive by frequent and copious supplies of water. One-half turfy peat, such as orchid-growers use, and that which is a light colour, with pieces of decayed moss, and rather sandy, is the best; one-fourth turfy loam, that which is called yellow or hazel loam is to be preferred; one-eighth pieces of greenstone, broken to about the size of a walnut; one-eighth silver-sand; incorporate the above well together, chopping the peat with a spade, but do not pass any of the compost through a riddle. In the above compost they thrive amazingly. They are not benefited by the application of manure, or by manure water of any description; to some species it is so detrimental as to cause death. The compost should be worked into the crevices and hollows of the rockwork with a pointed piece of wood, or some such implement."

The rock-work thus prepared can have soil added to suit the different ferns when they are planted. Leaf- 
mould and peat-earth, with plenty of silver-sand, all mixed together, is as useful for stove ferns as for those of the greenhouse and the garden.

Such ferns as are grown in pots will require frequent repotting. Seedlings should have the pots changed thrice in the year; mature plants should be repotted twice, once in spring and once in early autumn. Attend carefully to the drainage of the pots, giving each plenty of potsherds, and then a layer of sphagnum, filling to within half an inch of the brim with the compost. In repotting a fern, put one hand on the surface of the earth in the pot, letting the stem or stems of the ferns be steadied between the fingers, then reverse the pot, press upon the hole at the end till the ball of earth containing the fern roots is thrust out,-pick all the stones and drainage from about the roots, and push away as much of the old earth as is easily removed, thus loosening the roots; the drainage being already placed in the new pot, and a little of the compost, the fern may be placed therein, and more compost pressed down firmly on all sides. Newlypotted ferns should be shaded for a time. Enough water must be given to them thoroughly to penetrate the old ball of earth.

Ferns with creeping caudices, especially the dwarf kinds, will grow well upon the rock-work, and, in the course of two or three years, will not only clothe the rock, but form beautiful and varied little landscapes. Ferns in pots will be placed on stages, their position being decided by their size and manner of growth. Fern-pillars and fern-baskets will make additional ornaments for the fern house, and, as the fern-pillars are a novelty, we will proceed to describe them, as advertised by the inventor, Mr. J. Tyerman, Curator of the Liverpool Botanic Gardens. 
"A square brick, 9 inches by $4 \frac{1}{2}$, having its centre scooped out, a scallop-shell is modelled to fit the lower part of the hollow. This forms the front, and has a very ornamental appearance. The bricks can be built one over the other to form a wall or pier at pleasure. A hole in the bottom of the hollow cavity is made sloping to the back of the brick for drainage. The invention appears to me to possess the most merit when constructed into pillars of any convenient height, and cemented together or not at pleasure. A hollow space in the centre of the pillar could be filled with damp moss, hay, etc.; an ornamental vase on the top, containing water, might have a hole in the bottom with a cork, so adjusted as to allow the water to percolate through the hollow to the roots of the ferns. The chief point in planting the ferns is so to arrange them that the erect growing ones occupy the part of the pillar beneath the level of the eye; and the drooping on that above or upon the same level with the eye."

We proceed to give a list with descriptions of the stove ferns most easily procured and cultivated, many of the species having been recommended in papers recently published in the 'Journal of Horticulture :'-

Polybotrya Osmundacea. A climbing fern, attaining an elevation of 20 feet; fronds of two kinds, barren ones rising from a dark scaly stem, erect and short-stalked, spreading, 4 to 6 inches wide, elongated, triangular, toothed, deep shining green ; fruitful fronds bi- and tripinnate; leaflets oblong, pointed, erect, contracted. All the stems scaly. Twining round trees in the damp groves of Jamaica, and easily cultivated in a hothouse.

Gymnogramma chrysophylla. Golden Fern. Fronds bipinnate; leaflets oval, pale green on the upper surface, 
brilliant gold-colour on the under. A fern of rare beauty and well-deserved fame. Growing from 1 to 2 feet high, its glossy fronds turn at various angles, and show their golden lining, while the young crosiers rise from the caudex all covered with gold. It is often called the " king of the gold-ferns." In seedling plants, the powder investing the under surface is sulphur-coloured instead of golden. This fern requires a great deal of water, but it must on no account be allowed to stand about the roots. Very careful drainage is required, an extra proportion of sphagnum should be laid in the pot, and the broken moss should be freely mixed in the compost. It seeds freely, and the spores germinate readily in a high temperature and moist atmosphere. Its home is beside stumps of trees and in crevices of rocks in the West Indies and South America.

Gymnogramma sulphurea. Sulphur Gymnogram. Perhaps the most interesting of the golden ferns, from the extreme elegance of its form; the fronds are of a long triangular shape ; the pinnæ in pairs, far apart, and the leaflets prolonged, wedge-shaped. The general contour and bearing of the frond resembles that of our Asplenium Adiantum-nigrum. It is a small plant, seldom exceeding 8 inches in height; on the under surface it is covered with pale sulphur powder. A native of Jamaica.

Gymnogramma calomelanos. Silver Fern. Fronds larger than in the "king of the gold-ferns," bipinnate, evergreen, of a dull tint above and creamy-white beneath; stem and rachis ebony-black, with brown hairlike scales at the base. A beautiful Brazilian species.

Gymnogramma tartarea. Infernal Gymnogram. Resembling the last species, but of a much clearer white on the under surface. Fronds bi-sometimes tripinnate; 
leaflets oval. The stems are quite black, hence the specific name. Its home is Mexico.

Gymnogramma ochracea. Ochry Gymnogram. A fine member of the golden group. The fronds are of a large size, evergreen, the leaflets bright glossy green above, full yellow beneath, but the powder is less freely scattered. Very easy of cultivation.

Gymnogramma rufa. Red-haired Gymnogram. Fronds pinnate; stems red and hairy; veins red. This contrast in the colouring of the stem and veins gives a varied and pleasing appearance, and atones for the absence of the golden and silver powder so much valued in other species. It is a native of Mexico.

Gymnogramma tomentosa. Downy Gymnogram. Fronds somewhat triangular in form, bipinnate; leaflets sharply pointed, veined with red, the veins much forked, hairy; stems half the length of the frond, black. A delicate and beautiful Brazilian species.

Gymnogramma charophylla. Chervil-leaved Gymnogram. Fronds bi- or tripinnate, delicate in texture, of pale colour, in form resembling those of Cystopteris montana. We have it from the West Indies and South America.

Polypodium effusum. Spreading Polypody. Fronds tripinnate; leaflets small and elegant, of a triangular form, serrated. The fern attains a height of 5 or 6 feet, and the feathery form of the fronds, together with their arching habit, gives a great charm to the group. Caudex creeping. A Jamaica fern.

Polypodium longipes. Long-footed Polypody. Fronds pinnatifid, cut into seven segments, each segment narrow and tapering, evergreen, $2 \frac{1}{2}$ feet long, but the naked stem occupying more than half the length ; caudex creeping. A noble Indian fern. 
Polypodium phymatodes. Malay Polypody. Resembling the former, but having more numerous segments, and the fronds more decidedly pinnate; the leaflets triangular and broad. Caudex widely creeping. A native of the Malay Islands, Mauritius, and the West Indies.

Polypodium Phyllitidis. Hart's-tongue Polypody. In form the frond resembles our common Hart's-tongue, but it tapers elegantly to the base and the apex, and is covered with sori over the whole under surface. A West Indian species.

Polypodium lachnopodium. Woolly-footed Polypody. Fronds tripinnate, triangular; leaflets oblong, linear, stalked, hairy, dull green. Both the stem, the rachis, and the secondary rachis very hairy. Caudex erect. A Jamaica fern.

Polypodium piloselloides. Downy Polypody. Barren fronds simple, covered with light coloured hairs, 2 inches high; fertile fronds double the height, narrower and very hairy. Sori surrounded with small scales. Caudex creeping, slender. A West Indian species, well suited for baskets and rock-work.

Polypodium fraxivifolium. Ash-leaved Polypody. The pinnate fronds closely resemble the leaves of the tree from which the specific name is taken; the leaflets are stalked, narrow lance-shaped and tapering.

Polypodium verrucosum. Warted Polypody. Fronds slender, pendulous, 4 or 5 feet long, of a brilliant green colour. A magnificent fern, peculiar to the Philippine Islands. An evergreen.

Polypodium aureum. Golden Polypody. Fronds large, of a glaucous green, pendulous; caudex thick, hairy, resembling that of the Hare's-foot fern. A splendid species, bearing abundance of gold-coloured sori. 
Polypodium appendiculatum. Crimson-veined Polypody. Like the common Polypody in form, stature, and habit, but distinguished by two peculiarities in the venation; the point of the veins are thickened like clubs, and the stems, rachis, and veins are of a bright crimson colour. A native of Mexico, and flourishes well in a Wardian case.

Polypodium diveryens. Spreading Polypody. Differing greatly from the species hitherto described. The fronds are four times pinnate; the leaflets linear-lanceolate and sharply serrated. A West Indian fern, growing to a height of 4 or 5 feet.

Polypodium rigidum. Rigid Polypody. Fronds grassshaped, so thick and brittle as hardly to bend without breaking. A native of tropical America.

Polypodium Vittaria, Polypodium lineatum, Polypodium zosterifolium are narrow-fronded ferns, their grassy fronds often pendulous, glossy and growing in massive clusters, bearing a line of sori on each margin. Polypodium lineatum ornaments the trunks of old trees.

Polypodium diversifolium. Variously-leaved Polypody. Fertile fronds pinnate, 2 feet long; leaflets narrow, stalked, blunt, drooping, of a very delicate green colour, slightly notched. Barren fronds lobed, almost resembling an oak leaf, they turn brown in autumn and remain on the plant, contrasting beautifully with the young fronds which quickly succeed them. It is a native of Java and the East Indies.

Polypodium irioides. Iris-like Polypody. Frond simple, narrow, sword-shaped, resembling Iris leaves. A native of Mauritius and New Holland.

Polypodium musafolium. Musa-leaved Polypody. Fronds simple, egg-shaped, rigid, sessile, pale green, 
with darker veins, exhibiting a beautiful network. We have it from the Malayan Archipelago.

Polypodium subauriculatum. Half-eared Polypody. Fronds pinnate, 4 feet long, pendulous; leaflets narrow, tapering, bright green, slightly eared at the base. A noble plant, a native of the isle of Luzon. It should be planted where the fronds can droop at their will.

Polypodium sepultum. Covered Polypody. Fronds pinnate and lance-shaped, the leaflets thickly covered with fringed greyish scales. In form it greatly resembles the common Polypody of our walls and trees, but its more numerous segments and scaly covering mark its rarity. It is a South American species.

Polypodium vacciniifolium. Bilberry-leaved Polypody. Caudex creeping upon trees, shaggy; barren fronds simple, egg-shaped, 1 inch long; fertile fronds simple, rather longer, and narrower so as to approach the lanceolate form. The whole plant, with its shaggy creeping caudex and dark oval fronds, resembles an entire-leaved Ivy. Its home is tropical America.

Goniophlebium is a genus allied to Polypodium; its name is derived from gonia, an angle, and phlebs, a vein, and refers to the angular placing of the veins.

Goniophlebium Catharina. St. Catherine's Goniophlebium. Caudex creeping, scaly; fronds pinnate, triangular; leaflets blunt, oblong; sori in one row, on the upper part of the frond. We have it from Brazil.

Goniophlebium cuspidatum. Sharp-pointed Goniophlebium. Caudex slightly creeping, scaly ; fronds pinnate, 3 feet high; leaflets lanceolate. A native of Java.

Goniophlebium meniscifolium. Meriscium-leaved Goniophlebium. Caudex creeping, scaly ; fronds pinnate, 3 feet in length; leaflets lance-shaped, wavy, bright green, 
glossy, 6 inches long, and sharply pointed; stems bright green, jointed; sori large, yellow, in two rows; veins extremely beautiful, parallel, then uniting so as to form perfect cubes. A beautiful Brazilian species.

Goniophlebium neriifolium. Oleander-leaved Goniophlebium. Caudex creeping, scaly; fronds pinnate, 3 feet high; side leaflets lance-shaped, 6 inches long and $\frac{3}{4}$ inch wide, pointed; the leaflet at the apex is larger.

Elaphoglossum is a genus, with simple fronds and forked veins.

Elaphoglossum callcefolium. Calla-leaved Elaphoglossum. Caudex creeping; fronds barren and fertile; the fertile ones narrow and erect, about a foot high, the barren ones lance-shaped, pointed, dark glossy green, with waved edges and of the same stature. It is a native of Java.

Elaphoglossum crassinerve. Thick-veined Elaphoglossum. Caudex slightly creeping; fronds of two kinds, stouter than in the last species, and with thicker veins, as the specific name indicates; fertile fronds not much exceeding 1 foot in height; barren ones 2 feet high, waved at the margin; all the fronds are of a dull green colour. It is a West Indian species.

Elaphoglossum conforme. Conformed Elaphoglossum. Caudex creeping, scaly; fronds oval ; fertile ones small, and covered underneath with the small, but crowded sori; barren ones much taller, more pointed, a foot high, and very beautifully veined, with clusters of regular, oblique, evenly-branched veins. Its home is on shady rocks at the Cape of Good Hope.

Elaphoglossum longifoiium. Long-leaved Elaphoglossum. Caudex creeping; fronds of two kinds, 2 feet high; the fertile fronds are narrow-lanceolate, sharp at the apex, and erect; the barren ones a little broader, pointed, 
somewhat arched and undulating at the margin. We have it from the West Indies.

Elaphoglossum Scolopendrium. Hart's-tongue Elaphoglossum. Caudex short, creeping, scaly; fronds of two kinds; fertile ones with stems 8 inches high, their whole length about $1 \frac{1}{2}$ foot, erect, tongue-shaped; the barren fronds scarcely exceed a foot in length, they are of an oblong lance-shape, waved at the margin; both are of a beautiful pale green. Introduced from Brazil.

Stenochlaena sorbifolia. Barren fronds pinnate; leaflets leathery ; fertile fronds pinnate, erect, contracted ; caudex creeping and climbing. A native of Jamaica.

Stenochlena scandens. Climbing Stenochlcena. Barren fronds pinnate; leaflets a foot long, narrow-lanceolate, with a thickened border; fertile fronds bipinnate; leaflets long, narrow, grass-shaped at the ends and covered with sori. An East Indian fern.

Platycerium is a genus of ferns, the fertile fronds of which are cut into broad segments like the horns of an elk; the name is derived from platys, broad, and keras, horn. The various species grow mostly on trees.

Platycerium Stemmaria. Garlanded Platycerium. Fronds of two kinds; the barren ones sessile, elongated, ascending, only slightly lobed, kidney-shaped, spongy, depressed; the fertile fronds are simple, horizontal, thick and leathery, forked in the upper part in the form of a Fucus or Ulva. This fern may be found in profusion, growing upon the trees in African woods. It flourishes freely in any hot moist house.

Platyceriumalcicorne. Elk's-horn fern. Caudex tufted; fronds rising in a dense cluster; the fertile ones numerous and nearly erect, occupying the centre of the group, these are frequently forked, erect in the simple part of 
the frond, but with the forked segments bending and arching in every direction; the sori cover the under part of the segments; the barren fronds are round, or expanded horizontally, few in number, lying obliquely round the towering tuft of fruitful fronds. Found upon trees in the warmer climates of Australia.

Platycerium grande. Noble Platycerium. Barren fronds very large and spreading, at first kidney-shaped, but expanding into deeply cut lobes; the fertile fronds are smaller, but of the same character, and like those of the Blechnum boreale, they die away after ripening the spores, while the barren ones continue to flourish and enlarge year after year. Their form resembles that of some of the red palmate seaweeds, more than any other type of ferns. It is a native of India and New Holland.

The genus Acrostichum derives its name from Greek words, meaning the commencement of a verse, and refers to the finely cut foliage. It is a group of noble tropical ferns, and most of the species attain a height of 5 or 6 feet.

Acrostichum aureum. Golden Acrostichum. Caudex erect, from 2 to 3 feet high ; fertile fronds erect; barren fronds drooping, with thin light green pinnæ and leaflets. It is found in morasses in the tropics, and requires a heat of $80^{\circ}$ in summer.

Blechnum australe. Southern Hard-fern. Fronds pinnate, about a foot long; pinnæ 'sessile, sickle-shaped, pointed; the end one is entire and lengthened out into a long point. A handsome fern, easy of cultivation, imported from the Cape.

Blechnum Brasiliense. Brazilian Hard-fern. Caudex erect, 2 feet high; fronds pinnate or pinnatifid; the leaflets or segments, each measuring from 7 to 8 inches; 
the fronds are 4 feet long. A noble species, that should never be absent from a fern-house where there is plenty of room.

Blechnum gracile. Graceful Hard-fern. Another Brazilian species, which has the extra recommendation of being evergreen, but its fronds only attain the length of 1 foot; the stems are crimson in youth, and become darker in age, they are scaly at the base; the leaflets are long, narrow and pointed, nine on each frond.

Blechnum lanceolum. Small lance-headed Hard-fern. Fronds simple, lance-shaped, dwarf, evergreen, shining, about 6 inches long; sori linear; veins forked. Also a Brazilian fern.

Blechnum orientale. Eastern Hard-fern. Fronds thick, leathery, pinnate, 3-4 feet high. It is still scarce. A native of the West Indies.

Blechnum polypodioides. Polypodium-like Hard-fern. Fronds pinnate, linear, tapering elegantly towards the point. A native of Mexico and Brazil.

Blechnum trifoliatum. Three-leaved Hard-fern. Fronds simple or divided into three segments, or even into five; from 6-8 inches long, of a full green colour, and crimson stem and rachis. Some horticulturists make three species of this, calling the simple variety longifolium, the 3-cleft one trifoliatum, and the 5-cleft pinnatum. All the varieties are found in Brazil.

Adiartum curvatum. Crescent-leaved Maiden-hair. It has a naked stem and fan-shaped outline; its leaflets are crescent-shaped, and thickly placed on the secondary rachis; it will grow to the height of 2 feet, and require plenty of room for its roots. It is a Brazilian species.

Adiantum affine. Of similar growth, but with fewer pinnæ. A native of New Zealand. 
Adiantum formosum. Handsome Maiden-hair. Fronds tripinnate, 3 feet in length, $1 \frac{1}{2}$ or 2 feet in breadth; stems black; caudex woolly. A magnificent fern, highly ornamental to the fern-house. It is brought from New Holland.

Adiantum concinnum. Neat Maiden-hair. Caudex creeping; fronds bipinnate; leaflets pendulous, crowded, semi-transparent; the fronds also are drooping, 2 feet long, and very elegant. It is an evergreen species and easily increased. A native of the West Indies and tropical America.

Adiantum caudatum. Tailed Maiden-hair. Fronds pinnate ; stems long and slender ; pinnæ crescent-shaped; rachis extending far beyond the piunæ, curling at the point, and forming a bulb which easily roots and puts forth fronds. The colour is dull green, the form of the fronds elegant, arching, and often drooping. It is much used for ornamental baskets, and is an East Indian and Chinese species.

Adiantum reniforme. Kidney-leaved Maiden-hair. Fronds simple, kidney-shaped, evergreen, upon shortish stems; the whole frond from 3-6 inches in length, of a bright colour and glossy texture. Requires a good deal of heat. It is a native of Madeira.

Adiantum trapeziformé. Trapeziform-leaved Maidenhair. Fronds with long stems; the pinnæ forked, taking their rise from nearly the same point on the stem, and so making a fan-shaped outline to the frond; leaflets with four unequal sides, hence the specific name. This fern is a very desirable one; it is evergreen, easy to manage, and its arborescent style of growth gives it a pleasing appearance. It is found wild in the West Indies and Central America. 
Adiantum tenerum. Tender Maiden-hair. Caudex widely creeping; fronds four times pinnate; leaflets minute, numerous, glossy, evergreen. A very beautiful and elegant fern, resembling but surpassing, both in size and delicacy, our native species. Its home is the West Indies.

Adiantum Wilsoni. Wilson's Maiden-hair. Caudex creeping; fronds pinnate, formed of three or five leaflets of a leathery texture, and dark green colour. It is a native of Jamaica.

Adiantum Brasiliense. Brazilian Maiden-hair. An evergreen fern, growing a foot high; fronds bipinnate; stems hairy.

Adiantum cardiochlcena. Heart-shaped Maiden-hair. A large and very beautiful species, attaining a height of 3 feet. It has heart-shaped sori. Its home is tropical America.

Cheilanthes pulveracea. Powdery Cheilanthes. Fronds bipinnate; pinnæ divided into equal leaflets; the leaflets sessile, green above and white beneath; the general form of the frond is lanceolate.

Cheilanthes viscosa. Claminy Cheilanthes. Fronds tripinnate, triangular in form, three-branched; leaflets lanceolate, blunt, toothed, light green, covered with clammy, glandulous hairs. A native of Mexico.

Cheilanthes farinosa. Mealy Cheilanthes. Fronds bipinnate in the lower part, then pinnate, and only pinnatifid towards the apex, general form triangular, but tapering at the apex; bright green above, snow-white beneath; stem and rachis crimson shading to black, 12-24 inches high. A fern of rare and surpassing beauty; a native of the West Indies and tropical America.

Cheilanthes lendigera. Maggot-bearing Cheilanthes. 
Fronds tripinnate, a foot long; the leaflets planted singly and in regular rows, long and narrow in form, and of a muist, delicate green colour. The general form of the frond is triangular, but it is much drawn out at the apex which increases the elegance of the contour. There are few sori on each leaflet, and these are partially hidden by the recurved nargin. A native of tropical America.

Cheilanthes radiata. Rayed Cheilanthes. Fronds outspread; the pinnæ diverging in a starry form from the same point on the stem; the leaflets are oval and slightly eared, and scalloped; the stems are black; the caudex tufted. We have it both from the West Indies and tropical America.

Cheilanthes elegans. Elegant Cheilanthes. Fronds tripinnate, 1-2 feet high; the stem about one-third of the length; the pinnæ placed alternately, at least 1 inch apart; the pinnules beset by clusters of three, five, or seven tiny rounded leaflets, shining green above, hairy below, the brown stems hairy also. A South American species.

Cheilanthes spectabilis. Showy Cheilanthes. Fronds tripinnate, 3 feet long, of a beautiful pale green colour and very slender, so much so that its own weight often breaks it; caudex tufted. A Brazilian species.

Cheilanthes tenuis. Slender Cheilanthes. Of similar character, but smaller, and with brown scaly stems. A native of Mexico.

Cheilanthes Alabamensis. Alabama Cheilanthes. Fronds much divided; stems dark brown; leaflets very small, and of a glancous-green colour. A very pretty little fern from the United States.

Cheilanthes argentea. Silvery Cheilanthes. Fronds 
3-branched, pinnate, triangular in form; stems black and shiring; rachis and secondary rachis also black; leaflets dark green above, white beneath; caudex creeping. A dwarf evergreen species, measuring only 5 inches. Its home is Siberia.

Cheilanthes hirta. Hairy Cheilanthes. Fronds tripinnate a foot long; leaflets delicately small, covered with glandular hairs; stems brown. Very elegant. An African species.

Cassebeera dealbata. Powdered Cassebeera. Fronds bipinnate, minute, dusted over with white powder. A native of Mexico.

Alsophila is a genus of large tree-ferns, characterized by the sori being round, and placed halfway between the margin and the midrib. In cultivation they require ample space, and a quantity of water.

Alsophila articulata. Jointed Alsophila. Caudex 5 feet high, bearing a crown of fronds 6 or 8 feet in length, bipinnate, jointed; the stem covered with scales and prickles. A noble arborescent species from Jamaica.

Alsophila ferox. Rough Alsophila. Caudex 5 feet high, much taller in its native climate; fronds on the summit of the stem, large and feathery; the stem-rachis and secondary rachis beset by thorny prickles. A native of the West Indies.

Alsophila pruinata. Frosted-leaved Alsophila. Caudex erect, tall; fronds and stalks all covered with white woolly hairs reminding you of a coating of hoar-frost; the fronds are very feathery and beautiful, being very much divided, sometimes quadripinnate. It is a West Indian and Brazilian fern.

Alsophila villosa. Shaggy Alsophila. The stems and fronds are covered with shaggy hair instead of the frost- 
like wool ; the caudex is shorter, and the fronds longer than in the other species. This fern comes from Columbia.

Asplenium Brasiliensis. Brazilian Spleenwort. Fronds simple, sometimes 3 or 4 feet long, linear lanceolate, growing in a regular circle from the summit of the tufted caudex. A native of Mauritius. Asplenium nudum and Asplenium plantagineum closely resemble it.

Asplenium alternans. Alternate-leaved Spleenwort. Resembling the Ceterach, but destitute of scales. A native of the Himalayan Mountains.

Asplenium flabellifolium. Flag-leaved Spleenwort. Creeping caudex; fronds slender, pinnate, pendulous, much used for baskets. Brought from New Holland and Van Diemen's Land.

Asplenium Belangeri. Belanger's Spleenwort. Fronds bipinnate; pinnæ beset by two rows of narrow leaflets, the first on the upper side being pinnatifid. A fine feathery-looking species, a native of Java.

Asplenium latum. Gay Spleenwort. Fronds pinnate, erect, bright green, 2 feet high; caudex erect, sometimes branching. Allied to our native Asplenium marinum. Brought from the West Indies.

Asplenium oligophyllum. Few-leaved Spleenwort. Fronds pinnate, a foot long; pinnæ oblong, lance-shaped, few in number. Very elegant. A West Indian species.

Asplenium premorsum. Bitten Spleenwort. Fronds tripinnate, pinnules divided into three leaflets, and these into three segments, narrowing to the apex and slightly forked, which gives the præmorse appearance suggesting the name; stems slender and hairy. Asplenium laceratum, Asplenium erosum, and Asplenium Canariense resemble this species.

Asplinium pulchellum. Fair Spleenwort. Fronds 
pinnate, dwarf, elegant; pinnæ lance-shaped, or inclined to the crescent form ; sori long, narrow, and very bright brown. A very pretty fern. A native of the West Indies.

Asplenium radicans. Rooting Spleenwort. Fronds pinrate, $1 \frac{1}{2}$ foot long; stems black, extending beyond the pinnæ, and rooting at the apex. A native of Cuba.

Asplenivim rhizophyllum. Rachis-rooting Spleenwort. Fronds consisting of two lunate sessile pinnæ attached on either side of the stem, and an elongated one rounded at the base $\frac{3}{4}$ of an inch wide, traversed by the rachis, and prolonged to a fine point, the whole length of the terminal pinna measuring 4 inches. The fronds are of a full dark green, and at the end of the terminal one a bulb is formed which puts forth roots. If the fronds be pegged down, numerous plants will soon be formed. The plant soon covers the surface of a shallow pan, or would extend itself over rock-work. It is a native of North America.

Asplenium viviparum. Viviparous Spleenwort. Fronds tripinnate; leaflets very narrow, and of a lively green. The fronds resemble those of an Equisetum, from the number and narrowness of the leaflets. It produces young plants from the apex of the frond. It is a Mauritius species.

Nothochlana nivea. Snowy Nothochlana. Fronds bipinnate, 6 inches long; pinnæ in pairs; leaflets bright green above, becoming bluish in age, egg-shaped, covered on the under side with snowy powder, and having a marginal belt of dark shining sori. A lovely native of Peru and Mexico.

Nothochlana trichomanoides. Trichomanes-like Nothochlena. Fronds long and narrow; leaflets elongated, 
egg-shaped, slightly stalked, thin and membranous like our Hymenophyllums, dull green above, powdered beneath, the powder white at first, turning brown later. The fronds are often pendulous, about a foot long. Jamaica is its home.

Nothochlana tenera. Tender Nothochlana. Compact, slender, delicate, shining, bipinnate; pinnæ on wiry footstalks; leaflets lobed in the lower part, bluish-green, 8 or 10 inches high. A native of Chili.

Nothochlena tomentosa. Downy Nothochlana. Fronds tripinnate; leaflets very small, roundish, concave, and much crowded, woolly all over. Very popular in stovehouses, requiring great care in watering, as the fronds easily rot off. A Mexican species.

Nothochlena lanuginosa. Woolly Nothochlena. Fronds tender and delicate, of a heavy green colour, and very woolly; 6 inches high. A native of Africa and South America.

Platylorna flexuosa. Twining Platyloma. Stem zigzag, bearing at each angle a pinna of fire, six, or seven leaflets of an oval form, bordered with sori, and situated upon footstalks. It is found twining round trees in Peru and British Columbia.

Platyloma ternifolia. Three-leaved Platyloma. Pendulous, with leaflets in whorls of six, three leaflets on either side the stem. Very elegant, and suitable for baskets. A Mexican species.

Platyloma calomelanos. Beautiful black Platyloma. Grows about a foot long, bipinnate; the leaflets triangular, bluish-green, with thickened border; caudex creeping. It is found at the Cape of Good Hope.

Platyloma geraniifolia. Geranium-leaved Platyloma. Fronds light green, shining, triangular, 6-10 inches 
long, five-parted; the lowest pinnæ large, and having the first inferior leaflet much lengthened and pinnatifid, so that the fern has somewhat of the three-branched character; its pale glossy green colour, black veins, and russet sori give it a charming variety of tint. It grows in Brazil, Java, and India.

Platyloma Brownii. Brown's Platyloma. Fronds pinnate; leaflets stalked, lanceolate, pointed, entire at the margin. A handsome fern, attaining a height of from 1 to 2 feet.

Pteris arguta. Madeira Brake. Fronds bipinnate, delicate, and feathery, lance-shaped; leaflets small, pale green, narrow. Madeira, Azores, Portugal.

Pteris heterophylla. Various-leaved Brake. Fronds repeatedly divided, somewhat triangular in form; thie barren fronds have oval leaflets, fertile oblong ones; 1 foot in height. A Jamaica species.

Pteris lata. Broad Brake. Fronds tripinnate, triangular, drooping; leaflets narrow, lanceolate, deeply serrated; caudex creeping. Its home is Brazil.

Pteris longifolia. Long-leaved Brake. Fronds pinnate; the terminal leaflet much longer than the rest; hence the name; leaflets narrow, slightly stalked. A native of the West Indies and Philippine Islands.

Pteris aspericaulis. Crimson-stemmed Brake. Fronds 3- or 5-branched, triangular, or fan-shaped. Its peculiar attraction is its crimson stems; the segments upon the pinnæ are numerous, narrow, and regular.

Pteris macroptera is a 3 -branched species, with the pinnæ so deeply divided as to be pinnatifid; the segments are large.

Doodia is a genus named after Mr. Doody. All the species are rough. 
Doodia aspera. Rough Doodia. Fronds pinnate, upright, rigid, 8 to 10 inches high; leaflets sickle-shaped, sharply serrated, dark green. A native of New Holland.

Doodia caudata. Tailed Doodia. Fronds pinnate; stems smooth; caudex tufted. A very familiar species, imported from Australia.

Doodia lunulata. Crescent-shaped Doodia. Caudex creeping; fronds pinnate, slender, drooping, $1 \frac{1}{2}$ foot long; leaflets crescent-shaped, sharply serrated at the margin; stems reddish-purple. The most striking characteristic of this pretty graceful fern is, that its young fronds are always more or less tinged with red, being entirely red when they begin to uncoil, and very prettily tinted till nearly full grown. We have it from New Zealand.

Doodia monstrosa. Tasselled Doodia. Resembling the last species, of which it is probably a variety. It is a dwarf form, and very pretty and curious, because of the frequent divisions of the ultimate leaflet which form a crest on the apex of the frond; the leaflets are similarly divided, though in a less degree, for some distance down the frond.

Meniscium palustre. Marsh Meniscium. The generic name of this fern is derived from meniskos, a crescent, and refers to the shape of the sori. Fronds pinnate, 4 feet high; pinnæ 8 inches long; sori nearly covering the under surface of the leaflets. A magnificent fern. A native of South America.

Nephrolepis is a genus of ferns with kidney-shaped involucres, hence the name, derived from nephros, kidney, and lepis, scale.

Nephrulepis pectinata. Comb-shaped Nephrolepis. Fronds pinnate, linear-lanceolate, glossy, evergreen; 
pinnæ alternate, crowded, eared, one hundred pairs or upwards on each frond; veins forked; sori circular; involucres kidney-shaped. A Brazilian and West Indian species.

Nephrolepis Davalloides. Hare's-foot Nephrolepis. Fronds pinnate, at first upright, then arching, 5 feet long, they bend down below the margin of the pot; the sterile leaflets are broader than the fertile ones. We have it from the Malayan Archipelago.

Diplazium is a genus nearly related to Asplenium, but differing in having the sori in pairs. The name is taken from diplazo, to double.

Diplazium acuminatum. Tapering Diplazium. Fronds pinnate, smooth, shining, 18 inches long. A native of Ceylon.

Diplazium arborescens. Tree.like Diplazium. Caudex erect; fronds bipinnate, triangular, 3 feet long; leaflets light green, serrated; stems scaly. From St. Helena.

Diplazium juglandifolium. Walnut-leaved Diplazium. Caudex tufted; fronds pinnate, bright green; leaflets large, and but slightly serrated. This fern will grow if the stem be placed in a pot under a bell-glass; after a short time roots will sprout forth, and new fronds be formed from the base of the old one. We have it from South America.

Diplazium plantagineum. Plantain-leaved Diplazium. Caudex tufted ; fronds simple, fertile, dwarf. The fronds, planted like those of the last species, will take root, and it is also furnished with buds springing at the base of the fronds, by which also it may be propagated. Its home is the West Indies.

Diplazium striatum. Striated Diplazium. Caudex erect; fronds bipinnate, 4 or 5 feet in length; leaflets 
I foot long; the stems and the ribs of the leaflets are hairy. A native of Jamaica.

Diplazium sylvaticum. WoodDiplazium. Caudex erect; fronds pinnate, triangular in form, from 2 to 3 feet long; leaflets roundish, serrated; stem scaly. A species peculiar to Ceylon.

Diplazium Thwaitesii. Thwaites's Diplazium. Caudex c"eeping; fronds pinnate, hairy, about 6 inches high. Imported from Ceylon by Mr. Thwaites.

Fadyenia is a genus named after Dr. MacFadyen.

Fadyenia prolifera. Proliferous Fadyenia. Caudex tufted ; fronds simple ; fertile ones erect, central, narrow, lance-shaped, blunt at the apex, but narrowing to the base; barren ones horizontal, and producing young plants from the points, hence the specific name, much broader than the spore-bearing fronds, and narrowing very elegantly to the rooting apex; the fertile fronds measure about 5 inches; the broader barren fronds lying horizontally round the circumference are about an inch longer; involucres heart-shaped or horseshoe-shaped, thick, and hairy. A very curious fern. A native of Jamaica. It grows best in a pot plunged in a pan of water, and requires great heat.

Davallia bullata. Studded Davallia. A small dark green glossy fern. A native of the East Indies.

Davallia elata. Tall Davallia. Fronds drooping, from 2 to 3 feet long; they have a reddish tint in youth; caudex creeping on the surface.

Davallia pentaphylla. Five-leaved Davillia. Dwarf in size, but very pretty; the fronds cut into fine pinnæ; the leaflets very fine, and of a shining green. Very well suited for baskets. From the Malay an Archipelago.

Cibotium is a generic name derived from kibotion, a 
little box or chest, such being the form of the seedvessel of one group of ferns.

Cibotium barometz. The Scythian Lamb-fern. Caudex short and thick, densely covered with long brown crowded hairs; the stems hairy; an inverted caudex with a hairy shoot at one end, and supported by four stems, forms a rude representation of a lamb, and so gave rise to a number of legendary fables; fronds bipinnate, somewhat triangular-shaped, erect, 10 feet in length; the sori principally on the lower part; the stems are from 2 to 3 feet long. A Cochin-China fern.

Cibotium Schiedei. Schiede's Cibotium. Caudex ascending, arborescent; fronds bipinnate, drooping; the stems and caudex woolly. Very beautiful. A native of Mexico.

Cyathea arborea. Tree-like Cyathea. Caudex erect, ascending; fronds tripinnate, rigid, dull green, 6 to 8 feet long; leaflets scaly underneath; stems black, and beset with thorns; sori cup-shaped, the spores rising above the cup as if overflowing. A noble fern, belonging to Jamaica.

Cyathea dealbata. Powdered Cyathea. Caudex erect, tall, stout; fronds lanceolate, bipinnate; leaflets bluishgreen above, lined with silver white, and veined with the same; stems covered with ferruginous scales and down; sori reddish-brown, freely scattered upon the white lining of the leaflets. The fronds are from 5 to 7 feet in length, and the noble fern often receives the regal appellation "The Silver King." It is an article of food in its native country, New Zealand.

Cyathea elegars. Elegant Cyathea. Cauidex erect, tall, 8 feet and upwards; fronds tripinnate, 10 feet long; the lower pinnæ are spreading, but the frond tapers towards 
the apex; the stems are covered with whitish scales. A native of Jamaica.

Cyathea medullaris. Pithy Cyathea. Still more stately; the caudex like the bole of a tree; the fronds 14 or 15 feet long; the stems purplish. It grows rapidly, and is a very desirable fern where there is plenty of room. Its home is in the valleys of New Zealand.

Cyathea patens. Spreading Cyathea. Caudex slender, 3 or 4 feet high; fronds 6 to 8 feet long, tripinnate, yellowish-green; the stems light brown and scaly. Like the Cyathea elegans, it is a native of Jamaica.

Ceratopteris is a genus of aquatic ferns; the name is derived from two words, keras, a horn, and pteris, a fern, and relates to the horn-like form of the segments on the fertile fronds.

Ceratopteris thalictroides. This is a water-plant growing in stagnant pools in tropical America and Asia. The fertile fronds are erect, three or four times pinnate; the segments linear, contracted, and horn-like; the barren fronds are tripinnate, but the segments are oblong. In cultivation this fern should be placed in large pots, and plunged in a cistern. It is an annual, but little knobs or bulbs grow in the hollows between the segments of the frond, which easily root themselves, and the spores germinate readily also.

Hymenophyllum cruentum. Crimson Filmy-fern. Fronds simple, lanceolate, broad at the base, and narrowing to the apex, crenate at the margin, 6 inches long; the sori are borne on the margin, forming a fringe round it. Of a beautiful rose or blood-colour. This lovely species is peculiar to Chiloe.

Lygodium is a generic name derived from lygodes, flexible, and refers to the climbing habit of the group. 
The sori are placed in little spikes of overlapping scales somewhat resembling the cones of the Lycopods.

Lygodium Japonicum. Japanese Lygodium. Fronds branched, elegant, segments of the fertile ones contracted. Does not climb high, and requires great heat. A native of China and Japan.

Lygodium flexuosum. Climbing Lygodium. Stems prolonged to a great length; fronds attached to it in pairs opposite one another, some inches intervening between each pair; the fronds about an inch long on a foot-stalk of the same length. This species climbs freely around the boles of trees in its native jungles in the East Indies, and it is a very ornamental plant in a hothouse if trained round a pillar.

Lygodium palmatum. Palmate Lygodium. Very slen. der and graceful; barren fronds hand-shaped, cut into four or five segments like Passion-flower leaves; fertile fronds on the upper part of the rachis smaller, more divided; the segments much contracted; the whole branch measures from 1 to 3 feet; it is of a brilliant green colour, and does not require great heat to bring it to perfection. We have received beautiful fronds from the colony of British Honduras. It grows in the warmer parts of North America.

Trichomanes venosum. Veined Bristle-fern. A small species; pinnate leaflets narrow and lobed.

Trichomanes Bancroftii. Bancroft's Bristle-fern. Pinnate, minute; leaflets broad, crowded, sessile.

Trichomanes crispum. Brittle Bristle-fern. A larger species. Fronds pinnate; leaflets narrow, ovate.

Trichomanes muscoides. Muss-like Bristle-fern. Minute. Fronds lobed, but not pinnate.

Trichomanes sinuosum. Waved Bristle-fern. Fronds pinnatifid, minute. A rare tropical species. 


\section{CHAPTER VI.}

\section{DISEASES OF FERNS.}

Ferns, like all other plants, are subject to various enemies, endangering their being more or less injured or even devoured entirely. Snails and slugs are very fond of indulging themselves in a hearty repast of young fern fronds, and they will clear off those of the more delicate and succulent species as fast as they appear above the ground. When we look at a magnified drawing of the tongue of a snail, beset with its hundreds of teeth, we no longer wonder at the ravages they commit among our pets in the fernery. Very early morning, while the dew is on the ground, or late evening, is the time to make war upon them most successfully. The ferns have even more serious enemies among the beetle tribe. The grubs of the Otorhyncus sulcatus infest ferneries to a great extent, and have much better chances of eluding observation than the snail family. Rabbits nibble them freely when they can affect an entiance, but this is a danger occurring rarely, and easy to guard against. There are three kinds of fungi which fix themselves parasitically upon the fronds; one is the Uredo filicum, it is minute, of a red colour, and infests various ferns, as Cystopteris fragilis, Polypodium Dryo- 
pteris, etc. The second is black like a small bead, fixed by its neck to the substance on which it grows; it only infests dead stems of Pteris aquilina; its name is Dothidea filicina. The third is a still smaller enemy, not larger than a pin point; the Pteris is its favourite home, and you may take up dead fronds in the woods, and find the stem and rachis speckled all over with thousands of Spheria pantherina. These two last, seeing that they infest only dead stems, and those the stems of the most abundant of our wild ferns, are not enemies to cause much anxiety, and do not necessitate the calling out of a volunteer force for protection.

The greenhouse and hothouse ferns have fierce enemies in small insects called by gardeners thrips, and scale. Syringing is the best safeguard against the appearance of these foes; but when they have effected a settlement they can only be dislodged by thorough fumigation and careful washing with a decoction of tobacco and sulphur. When the insect called "mealy bug" appears, there is no cure but fumigation. 


\section{CHAPTER VII.}

\section{THE USES OF FERNS.}

Ir takes but few words to convince a man of taste of the many claims which the fern-family possess to beauty, but their utilitarian qualities are less easily demonstrated. Yet even in this respect the ferns are entitled to some notice, for they do fulfil several useful offices of some importance both to man and animals.

M. Duchesne says of the Acrostichum alcicorne,"Avec le sommet de la racine séchée, et réduite en poudre, on forme un pain grossier, à la Nouvelle-Zélande ;" and other authors bear witness to the importance once attached in that country to the roots of Pteris esculenta, as an article of food; old plants were preferred for this purpose, laid to dry for a year, and then macerated, the woody matter being rejected. But in these days of extensive colonization and universal commerce, the New Zealanders find more palatable and nourishing food easy to obtain, so they only chew fern-root as a superfluity.

A nother Acrostichum is much valued in some countries for thatching houses, while in Arabia, according to Duchesne, a poultice of the leaves is applied successfully to burns. The same author recounts that a golden- 
tinted species, of the same family, is much valued as a slightly aperient medicine.

Still quoting from Duchesne, we find that the Polypodium arboreum is much valued in Cochin-China, its stems being used for palisades, and accounted most desirable for thatch, and the ashes of the whole plant being found richly productive of potash.

The inhabitants of the South Sea Islands gather the fronds of Polypodium phymatodes and Angiopteris evecta, and bruise them in order to obtain an aromatic oil which they contain, and which is used to perfume the cocoanut oil.

The Aspidium group come out strongly in their adaptability to useful ends, as is testified by legendary and even by modern lore. Nephrodium rigidum has the recommendation of M. Duchesne, he says, "L'infusion est usitée en Sibérie contre les maladies goutteuses, elle y sert à succédanée au thé, sous le nom de 'thé de Sibérie ;' on l'emploie encore pour aromatiser les nardes." We do not expect that M. Duchesne's receipt will be widely adopted by our readers, for the Nephrodium rigidum is too rare and valuable as an inmate of our ferneries and herbariums, for us to employ it as a substitute for the now cheap luxury of tea, even if we could be convinced of the excellence and beneficial effects of the "thé de Sibérie."

The Nephrodium esculentum is an article of food in tropical countries.

'I'he virtues of the Nephrodium Filix-mus are manifold, and it is worthy of remark and of thankfulness, that the healing qualities of the fern tribe are most abundantly present in a species which is found freely all over the globe. 
The male fern has long been esteemed as a medicinal plant, and in searching for the comments of old authors upon its virtues, of course we find a considerable mixture of superstitious and romantic fable. Theophrastus, Pliny, and Galen praise it, and Dioscorides says, "The root of the male fern, being taken to the weight of half an ounce, with black hellebore, is an excellent vermifuge. The root hereof is reported to be good for them that have ill spleen; and being stamped with swine's grease and applied, it is a great remedy against the pricking of the reed." Tragus goes deeply into the region of fable, in recounting the qualities of the male fern, and informs us that there is such an antipathy between that plant and the reed, that the one will not grow within sight of the other. In the case of a horse that has fallen ill from any unknown cause (probably alluding to the then popular notion of animals being bewitched by the evil eye or otherwise), he recommends that a piece of the root of the male fern be laid under its tongue, and thus the disease will be expelled.

It is a matter of history, that Madame Nouffer announced, in the reign of Louis XVI., that she had discovered a wonderful specific against tapeworm. The King desired to purchase her secret, which she at last yielded to him for the moderate price of 18,000 francs, and it proved to be merely the root of Filix-mas! M. Duchesne adds his testimony to the excellence of the specific, "Le principe actif de la racine est la filicine. Les feuilles pour coussins et matelas contre le rachitisme. La racine très-usitée en médecine humaine et en médecine vétérinaire. En Auvergne on en fait de très-mauvais pain."

But the highest medal given to the Nephrodium Filix- 
mas is the earnest and weighty notice by Dr. Lauder Lindsay, published in the pages of the 'Phytologist ;' he says, "The root of Filix-mas has been repeatedly used, of late, in this hospital, in the treatment of tapeworm. It has also been extensively applied to the same purpose by the profession in Elinburgh, and in other parts of Scotland. It had fallen into disuse greatly in this neighbourhood, in consequence of supposed inefficiency, but undeservedly so, until Professor Christison, in two papers published in the 'Medical Journal' for June, 1852, and July, 1853, showed that the want of success, in some cases, depended on bad preparations of the root, or old roots, being used. He found it almost uniformly successful in the form of an oleo-resinous extract obtained by percolation of the root with ether. It is recommended in the dose of from eighteen to twenty-four grains, followed by a purgative. This fern was first used at Geneva by Peschier some twenty or thirty years ago, in the form of an ethereal extract; but it appears to have been recommended as a vermifuge by Theophrastus, Dioscorides, and Galen, and since formed Madame Nouffer's celebrated remedy. The only caution necessary in using it, is probably that it ought always to be had fresh, but it has been found efficient after being kept a year. Pereira gives an excellent article on this fern in his Materia Medica, which may be referred to as to the chemistry of the root."

The homœopathists make use of this fern in their medicines; they give the following directions concerning it in their pharmacopœia :- "We gather this plant in the summer months. That which grows on stony declivities towards the north, is considered the most efficacious. Of the fresh-dug roots, we take inner marrow, and we 
likewise take the youngest rudimentary leaves, which are neither withered nor gangrened, of a bright green colour, a strong sweetish and offensive smell, and similar taste, which afterwards becomes bitterish, acerb, and slightly astringent ; both are stripped of their brown epidermis, and prepared according to Class 2."

The young stems of the male fern are said to form an excellent substitute for asparagus ; the Norwegians gather them as an ingredient in their beer, and they probably improve its wholesomeness, if they do not add to its flavour. The ashes of this fern have been used instead of or along with those of the common brake, for the tanning of leather, the manufacture of glass, and the bleaching of linen; and in many places the fronds are cut and stacked as fodder and litter for cattle.

The Lady-fern may also advance some claim to utility as well as to ornament. Duchesne enumerates its capabilities:- "On la donne l'hiver aux cochons pour les nourrir. Les feuilles servent de litière aux bestiaux. On les emploie encore comme combustible pour chauffer le four, cuire la chaux, le plâtre, les briques. Les cendres sont bonnes comme engrais. On s'en sert dans les verreries, les blanchisseries. La lessive des cendres de toute la plante sert pour le vernis de la porcelaine de Chine."

It is used in Ireland very extensively for the packing of fish and such purposes.

One species of Cyathea is eaten by the negroes in the Isle of France; the inner part of the stem is the edible portion. It does not speak very highly for the tastefulness of the aliment that Duchesne adds, "They eat it principally in seasons of fasting."

The scaly Spleenwort used to be much valued as a 
dressing for wounds, especially ulcers. Vitruvius relates a curious circumstance regarding this fern which is quoted by Mr. Newman. "In Crete," he says, "there is a river that flows between the cities of Gnosus and Cortyna; on the banks on the Cortyna side the scaly Spleenwort grows in great abundance, and the swine there are ascertained to have no spleen; on the Gnosus side of the river, however, there is not a single plant of the scaly Spleenwort to be found, and there the pigs are endowed with spleen. Hence the name Spleenwort is supposed to be applied to the Asplenium family. This and other members of the group long maintained their character for acting on the spleen.

The Ceterach was not the only species thus famed; the Asplenium Adiantum-nigrum was considered equally curative. Decoctions of one or other of these could hardly fail to cure any complaint in which the spleen could have or be supposed to have any share; indeed, from the faith with which herbalists speak of the virtues of these plants, it could only be through wilful and gross neglect of these beneficent gifts, that sickness could remain on earth.

The common brake may vie with the male fern in its extensive adaptability to the service of man and animals. The root of it is recommended by some authors as a cure for rickets in children, and to lie upon a bed of it used to be prescribed for the same disease in older persons. In common with Filix-mas it possesses the qualities necessary for a vermifuge. The young shoots boiled as a vegetable for the table are fairly palatable; cooked roughly and in great quantity, they make excellent food for pigs. The fronds cut when green and left to rot upon the land make capital manure ; stacked and hoarded, they make good litter for the foldyard. Duchesne states 
that both the root and the young fronds are accounted good food in Japan.

The ashes of ferns in general, and of this fern in particular, contain a large quantity of potash, and, on this accunt, are of much value to the glass manufacturer, soap boiler, and to all washerwornen; it is also used extensively on the Continent, in the preparation of kid and chamois-leather.

There is a kind of varnish used in the manufacture of china, called fern-oil. The Chinese obtain it thus :- they take a very great quantity of well-dried fern, and spread it thickly over a piece of ground, upon this they place a layer of large limestones, newly calcined; on these they sprinkle just enough water to wet the surface. Upon the stones they lay another thick bed of fern, and then place another laver of limestone, which they moisten, covering it as they did the last with quantities of dried fern. They build on thus, with alternate tiers of fern and lime, till the heap is ten feet high. Then they set fire to the fern, which soon burns away and leaves a quantity of mixed lime and ashes. This mixture is laid between new beds of fern and burnt again, and the operation is repeated five or six times. When the last burning is concluded, the mixture of lime and ashes is carefully collected, and thrown into large vessels of water, one pound of Rekio being added to every hundredweight of it, and the whole stirred together; the finer part then floats on the surface like cream, while the coarse falls to the bottom : this they take off, and leave to stand alone, when, after a time, the creamy part sinks and the water is then poured off. The residuum is the fern-oil. This oil they mix with oil of stone, procured in a similar manner, and with the mixture they cover all 
vessels that they wish to varnish. The Chinese use this less than they did in former times, pretty generally substituting wood-ashes for fern-ashes. To this substitution they ascribe the falling off in the beauty of their china.

The Maiden-hair fern was famous for many qualities, mediciual and sentimental, but all or most of these have fallen into disfavour. Mr. Newman quotes an article from the 'British Herbal,' descriptive of the qualities in question: "It would be endless to enumerate all the virtues of this plant, of which treatises have been written; perhaps the reader may think those already mentioned more than fall to the share of any one vegetable; however, as it contains a very fine nitrous salt, of all others the most universally useful in medicine, it may probably be serviceable in most cases, without any great exaggeration of its virtues, and, because the native salts of plants are best got out of them by boiling, the form of a decoction seems to be the most proper to take it in." In the south of France they still wash the hair with a decoction of this fern, and the splendid tresses of the French and Italian women speak eloquently in its favour.

An article of commerce, called Pulu, is produced by various species of ferns growing in Madeira, the Canaries, and Azores. This is an elastic, golden, silky substance, and grows on the caudex and lower part of the stem of the Dicksonia culcita, and Cibotium glaucum, Chamissoi, and Menziesia. On this subject, Sir William Hooker further tells us that the Pulu is an important article of commerce in the Sandwich Islands; the export commenced in 1851, and, in 1858, 313,220 pounds were exported. It is used for stuffing pillows and cushions. 
"The fern which produces the Pulu," he quotes, "grows on all the high lands of the Sandwich Islands, at an elevation of about one thousand feet; though found more or less in the five principal islands, the trade in it is chiefly confined to the districts of Hilo, Hamakua, and Puna, in Hawaii. The Pulu is produced round the stalk, where the stem or leaf shoots out from the stock of the fern, and only a small quantity is found on each plant, amounting to two or three ounces. It takes four years for the plant to reproduce this amount. The number of persons, including men, women, and children, engaged in gathering Pulu, varies from two to three thousand. The labour of gathering the material is very tedious. When picked, it is wet, and has to be laid to dry on racks or mats. Facilities for drying, packing, and shipping are improving every year, and the article is now shipped dry and in good order, closely packed in wool bales." (Mr. M. C. Cooke.)

Early writers have described, as one of the marvels of nature, a Vegetable Lamb. This is now ascertained to be a fern. The silky down, analngous to the Pulu, covers the undeveloped fronds and the caudex thickly and in great abundance. The "Lamb," says Mr. Moore, "consists merely of the decumbent shaggy caudex of a fern, which it has been supposed is that of Cibotium Barometz; when turned upside down, the bases of four of its fronds being retained as legs, by the aid of a little manipulation, this not inaptly resembles some small animal, and may fairly rank as a vegetable curiosity."

The entire acceptance of the 'Travellers' Wonder regarding this so-called Vegetable Lamb is proved and ealarged upon by Darwin; in his quaint poem upon the 'Loves of the Flowers' he thus writes :- 
"Cradled in snow, and fann'd by arctic air,

Shines, gentle Barometz, thy golden hair;

Rooted in earth each cloven hoof descends,

And round and round her fiexile neck she bends,

Crops the gay coral-moss, and hoary thyme,

Or laps with rosy tongue the melting rime,

Eyes with mute tenderness her distant dam,

Or seems to bleat, a vegetable Lamb!"

It is a proof how far imagination can delude reason, when the poet could endow the hairy caudex and stems of a fern with a "rosy tongue," "cloven hoofs," and eyes beaming "mute tenderness for its distant dam." Of course Darwin drew his figure from the description of others; had he been able to test facts by the evidence of his own senses, his "Vegetable Lamb" would have appeared under a very different aspect.

Duchesne names two species of Osmunda endowed with useful qualifications; one, Osmunda cicutaria, a native of St. Domingo, was used as a plaster to cure the bite of serpents; and another, Osmunda lancea, was accounted a good medicine in affections of the liver. He also records that a nourishing and fairly good dish was made from these plants during the siege of St. Domingo, but we can attach no more faith to the excellence of cookery in time of siege, when food is hardly attainable, than to the diet used by the negroes in the Isle of France, "more especially during seasons of fasting."

The Adder's-tongue was formerly much used by the people of Scotland in making ointment, according to Lightfoot. This ointment is still made by the medical herbalists of America, and the herb may be purchased in all our large towns for that purpose, but the fresh fronds make better ointment. Old wives have never 
ceased to employ the Adder's-tongue; thus the first time I found the small fern, I was guided to it by an old Wiltshire woman, a dealer in "simples;" and Miss Attwood writes, that in Herefordshire they employ the Adder's-tongue in making "May ointment." The old herbalists praise this ointment very much, and some of them ascribe similar virtues to that made from the Moonwort; but all receipts regarding the use of that fern partake largely of the fabulous and superstitious.

In the allied group, Lycopodiacea, we have various species used medicinally. The most useful in every respect is the Lycopodium clavatum, or common Club-moss. It is believed to be a remedy for that terrible Polish disease, called Plica; and in the homœopathic practice it is said to be applicable to so many symptoms, that in reading over the list one receives an impression that all the ills this poor flesh is heir to might be cured, or at any rate alleviated, by the Lycopodium tincture. But in carefully considering the symptoms so particularly enumerated, they resolve themselves into the features of a class of nervous disorders in which weakness of the eyes, headache, and nervous debility are the outward and visible signs. The new Pharmacopœia gives the following directions for gathering the herb:- "The fruit containing the yellow spores furnishes the officinal part of the plant. We gather the powder from the plant by roasting and beating it, towards the end of summer. It is a powder extremely fine, pale yellow, unctuous to the touch, inodorous, immiscible in water, on which it floats ; it is often adulterated with the pollen of the pine, sawdust, chalk, lime, or other powders coloured by gamboge. In this last particular the fraud may be detected by a solution of potash, which gives a red tint to the Lyco- 
podium powder, and as to the mineral powders, we recognize them by their sinking in water."

Mr. Baird tells us that the seeds of this plant are much employed in Germany, in producing artificial lightning upon the stage; it has also been used extensively in the manufacture of fireworks. M. Duchesne asserts that "it played a grand rôle in the religious ceremonies of the Druids," but he does not describe the manner of its employment. The tough stems and branches may be woven into mats and rustic ornaments, and are thus used in Sweden and Germany; not being wholly disregarded for such purposes by our own peasantry, according to Wordsworth, who relates of the Westmoreland shepherd lads :-

$$
\begin{aligned}
& \text { "And with that plant, which in our dale } \\
& \text { We call Stag's-horn or Fox's-tail, } \\
& \text { Their rusty bats they trim." }
\end{aligned}
$$

The Lycopodium Selago was praised for its medicinal virtues by Pliny. He relates with how much ceremony the Druids gathered this healing plant; they used it in diseases of the eye, and also as a charm to avert misfortune. It has strong cathartic qualities, so it may come into fashion again. The Highlanders use it to fix colours in dyeing, instead of alum. The peasants in the northern countries of Europe employ it as an emetic. Duchesne says it is much valued in veterinary medicine as a cure for dropsy.

The Lycopodiim alpinum, when mixed with Brazilian wood, and well boiled, imparts a good blue colour. In Iceland they use it with Whortleberry leaves, when it forms a yellow dye. M. Duchesne says that the "Lycopodium selaginoides avec un peu de bois de Brésil 
donne un joli gris ;" so we find that from this group we get three good dyes, "durable blue," " pretty grey," and "pleasing yellow."

Even the Equisetum arvense has medical and edible qualities, according to M. Duchesne. Dried, it is used as an astringent and diuretic in Vienna, he says, and in Italy the young shoots are used for food.

The virtues of Dutch rushes need little setting forth. The crystal-laden stems are useful for polishing wood and metals, for cleaning, and everything that can be furbished and brightened by a good scrubbing. The very round stems are used (according to M. Duchesne) for enlarging the holes in flutes, and for polishing the holes in clocks and watches. Gilders use them to "adoucir le blanc qui sert de couche à l'or." Perfumers use them to reduce the talc to powder and make it a fit basis for the essences.

We thus find that the observation and ingenuity already applied to the ferns and their allies, has discovered a few important uses and a great number of lesser ones. Further study and observation will doubtless discover more, and we may well expect such a result in days when fern-collectors are so numerous and so persevering. 


\section{CHAPTER VIII.}

PRESERVATION OF FERNS FOR THE HERBARIUM.

There is no group of plants better calculated for preserving in an herbarium than that of the ferns and fernallies. These plants possess an active principle, consisting of a volatile oil and resin, which has destructive effects upon some of the radiate and annulose animals. Since the time of Dioscorides, the male-fern has been celebrated as a vermifuge. The species of Acarus and Anobium, so very destructive to the herbarium, are not far removed in essential characteristics from the entozoa which torment the human frame. No direct experiments have brought the principle to actual demonstration, but it is a reasonable inference to draw, that those qualities in the ferns which are so obnoxious to the worms infesting the bodies of animals, brute and human, should be equally obnoxious to those relatives of the worms which infest dried plants.

In preparing a collection of dried ferns, our first care must be to select perfect and typical fronds. There is too great a tendency in this, as in other and more important matters, to affect the curious and the uncommon, and to neglect the true. When the whole of a fern-plant can be contained in a sheet of the herba- 
rium, by all means keep it as a whole; this can only be done with the smaller ferns; in most of the Nephrodiums, and in the other large species, we shall find it difficult to get a frond small enough to lie upon one sheet, and yet not a dwarfed frond, for that is not admissible as a specimen of the normal type. When the frond is too large for the sheet, it must be folded to the requisite size while yet fresh, and a sheet of the botanic paper placed between the folds, so that the different parts may not touch one another. Mr. Newman tells us that colour can only be retained by using Bentall's paper, and you should start with a good supply of it, so that several sheets may be placed between each sheet of specimens. Frequent changing is neither necessary nor desirable; the fronds may lie under a light pressure for twenty-four hours in hot weather or in a warm dry position, or for double that length of time if the weather be damp; the paper should then be changed, and the position of the frond can be altered at the same time, as it will not have begun to stiffen; but after that change no further one is necessary. If the collector has time and space for abundant specimens, he should, after securing two average and perfect specimens of the normal type of the fern, select specimens of various sizes, the most gigantic and the most dwarfed within his reach, and also specimens of every variety into which the species is apt to run. Further, he should press specimens in every stage of fructification.

When the specimens are sufficiently dry and firm the collector must proceed to fasten them on the sheets of the herbarium. Strong cartridge paper is the best, as it forms a safe backboard for the fronds, which soon become extremely brittle. If the sheet will admit two 
fronds of a species, one should be placed so as to show the upper surface and the other to exhibit the fructification. If the two cannot lie on one sheet, two different ones must be devoted to display their different surfaces. Where there are two kinds of fronds on one fern the same rule holds good: if you can dispose the two side by side, it is desirable that you should do so; if they are too large for that, then the one must follow the other on successive sheets. Mr. Moore recommends that the specimens should be so far moveable as to admit of being taken in the hand for examination; this may be managed without running the risk of the delicate branches being broken, by every jolt given to the herbarium, if cardboard straps be employed, which, being passed through a little slit on either side of the stem of the fern in different places, secure the frond firmly to the sheet, and yet admit of being removed and replaced at pleasure. They may also be secured by thread ties or gummed straps, or left loose and enclosed in an enveloping sheet of still larger paper. In all cases they should be fully labelled, the locality where the fern grew, and the date of gathering it, being carefully stated. The sherts containing the dried ferns may be placed in the shelves of a cabinet, in drawers, or between the boards of portfolios, as the collector pleases, but in any of the positions he must take good care to shield them from dust, damp, and careless violence. 


\section{CHAPTER IX.}

DISTRIBUTION OF FERNS.

UPWARDS of three thousand species of ferns are known upon the globe. They reach their maximum in numbers, size, and beauty, in the humid valleys and islands of the tropics. In New Zealand, Van Diemen's Land, South America, and parts of the East and West Indies, noble ferns are found, their giant trunks rising to the height of thirty or forty feet, from the top of which feathery fronds arise, stretching many feet upwards nearer to the lowering clouds, then bending outwards in many an arch of exquisite symmetry, or drooping in a pendulous manner, as if unable longer to support their own light weight. In the same damp but heated atmosphere climbing ferns flourish, twining round the boles of forest trees to the height of twenty feet, or extending from bush to bush, and making endless festoons of feathery foliage, rivalling in elegance our Passion Flowers and Climbing Vetches. There, too, shrubby ferns mingle with the underwood, or stand in symmetrical beauty alone, equalling our smaller trees in height, and with boles either tall enough to suggest the column with its capital of foliage, or only high enough to prevent its pendent eight-feet-long fronds from touching the ground. 
The banks and flowery turf, too, have their myriad of ferny denizens, varying in form from unbroken outline of the Hart's-tongue to the feathery frond of the Hare'sfoot; some are so minute as to seem like some small weed upon the earth, or bark; and some rise nobly to the height of many feet, not outdone in grace or stature by the Pampas or Tussac grass. Such are the ferns of the tropics, exquisite in beauty and grandeur, and almost countless in numbers.

Ferns reach their minimum in the cold of the polar regions; very few species flourish there, and those are dwarfed, tiny plants; but to ferns there is no minimum of beauty, for the silvery Cheilanthes of Siberia, though but three or four inches high, with its dark stem and rachis, and evergreen glos.y leaflets, all lined with snowy whiteness, is a very gem of beauty. In temperate regions great numbers of ferns are found, of great beauty and considerable size, but they are not so grand in stature as the tree-ferns of the tropics. Thus while we look to Mexico, Brazil, the West Indian Islands, the hotter parts of India, Australia, and New Zealand, to furnish us ferns for our hothouses, we look to the milder zone in these countries, and to the South of Europe, and the islands in temperate regions for those of our conservatories, and to North America and Germany for the hardy species to supplement our native group in the open fernery.

As ferns flourish in all climates, so they affect all sorts of habitats. Some delight especially in caves; some make a sine quâ non of the vicinity of waterfalls; some again require the deep shade of rocks or trees; on the other hand, sea air and a salt-laden atmosphere are necessary to some, others cannot live except on heights 
of many hundred or even thousand feet above the sealevel, and some even select the craters of volcanoes for their home, those of Pinchincha, near Quito, and of St. Vincent's Island, each having its especial fern as denizen.

They are as variable in choice of soil as in their other predilections. Some, as the Polypodium Robertianum and Nephrodium rigidum, cannot live except on limestone; others, as the Allosorus crispus, prefer anything to lime; some require bog earth; some seem to object to the presence of any earth at all, planting themselves in such narrow fissures or mere cracks in the rocks that it seems impossible that any room at all can be found for earth; and others growing parasitic on the bark of trees, seeming to draw their entire nourishment from the surrounding air.

The proportion that ferns bear to flowering plants varies in different countries. In England there is one fern to thirty-five flowering plants; in Scotland one to thirty-one. In Jamaica ferns form one-ninth of the flora, in New Guinea one-fifth, in Ireland one-sixth, in the Sandwich Isles one-fourth, in equinoctial America one thirty-sixth, in Portugal one hundred and sixth, in Greece one to two hundred and twenty-seven, in Greenland one to ten, at the North Cape one to seven, in Sweden one to eighteen.

This table, which we take from Mr. Moore's 'Handbook,' demonstrates that ferns bear a much larger proportion to flowering plants on islands than on continents - Ireland and the Sandwich Isles showing the highest proportion, only nearly equalled by Greenland and the North Cape, where the flor.al vegetation is at the lowest. There is no doubt that the atmosphere preferred by the majority of ferns is a calm damp one; it is only in very 
exceptive cases that they prefer exposure. Indeed, a dry and exposed situation generally dwarfs the size and detracts from the grace of contour in any fern accustomed to a more sheltered position, and in this lies the secret of most of our varieties.

The arborescent ferns are those which exercise the greatest influence in the beauty of the landscape. Like noble Palms they stand, their plumy capitals unequalled in grace and elegance, their stately columns chiselled with diamond-shaped indentations where old stems have fallen off. The sites chosen for their home are valleys and terraces, often at great elevations, from two to three thousand feet above the sea. The shrubby ferns have also an influence in the external beauty of the surrounding landscape. In New Zealand and the South Sea Islands their boles attain a height of ten or twelve feet, their verdant plumes rise many feet higher and then arch outwards or droop towards earth; the well-developed fronds from twelve to eighteen feet in length. Ferns, either arborescent or shrubby, must ever be objects of striking beauty, whether they are seen standing in lone magnificence, or clothing the banks of the raging torrent, and mingling their feathery foliage with the spiny leaves of Aloes and Cactuses. Herbaceous ferns are those of the temperate zones, and none of these attain a very great height; perhaps our Osmunda regalis, in its ten feet glory, on the banks of Loch Fine, is as striking an object as any of the herbaceous class found in the temperate regions of Europe, Asia, or North America. 


\section{CHAPTER X.}

\section{CLASSIFICATION OF FERNS.}

WHEN first the study of ferns began to be lightly touched, the mode of classification was according to the shape of the frond. A very little further examination into the structure of the plants convinced the students that this mode of arrangement would not do. Then the form of the sori was fixed upon, and though good so far, alone it was not found to be sufficient. Sir J. E. Smith proposed the form and attachment of the involucre as the criterion of distinction in the family, and this mode of classification has given, and gives much clearness, and consequent satisfaction. Sir William Hooker follows this plan of arrangement, combining with it the observations noted by Mr. Moore and others, on the presence, modifications, or absence of an elastic ring. The venation of the fronds and the connection of the veins with the sori are also points of immense importance in the investigation and classification of ferns.

All ferns may be divided into Annulatæ and Exannulatæ, the former division containing the true ferns, both dorsiferous, or bearing their fruit on the back of the frond, or marginal, bearing their fruit on the margin; and the latter, including the pseudo-genera Osmunda, Botrychium, and Ophioglossum. 


\section{TABLE OF GENERA.}

\section{Order Filices.}

Suborder 1. Polypodieæ.-Capsules dorsal or marginal, surrounded by an articulated elastic ring, and opening transversely and irregularly. Fronds circinate in vernation.

A. Capsules opening transversely, arising from the back of the frond; the ring vertical, usually incomplete.

* Nudisore.-Sori destitute of involucre.

1. Gymnogramme. Sori oblong or linear, on forked veins.

2. Polypodium. Sori subglobose.

** IndUSIATA.-Sori furnished with an involucre beneath the sori.

3. Woonsia. Sori subglobose. Involucre more or less cup-shaped.

4. Cystopteris. Sori subglobose. Involucre ovate, cucullate at the base, and having its origin beneath the sorus.

5. Aspidium. Sori dorsal, subglobose. Involucre orbicular and peltate.

6. Nephrodium. Sori dorsal, subglobose. Involucre subcordate, and fixed by the sinus.

7. Asplenium. Sori dorsal, linear, or oblong, rarely curved or somewhat horseshoe-shaped, attached laterally to the veins, and opening towards the midrib.

8. Scolopendrium. Sori dorsal, linear, in opposite pairs, and opening towards each other.

9. Preris. Sori continuous, dorsal, but at the margin on a marginal receptacle. Involucre formed of the reflexed and generally membranous margin of the frond.

10. Adiantum. Sori dorsal, roundish. Involucres 
of the same-shaped portions of a reflexed and altered margin of the frond, bearing the capsules upon them.

11. Cryptogramme. Sori oblong or linear, situated towards the apex of the veins, and covered by the involucre formed of the broad revolute margin of the frond. Fronds dimorphous.

12. Blechnum. Sori linear, continuous, parallel with and near the costa, running transversely, with the veins rarely submarginal. Involucre of the same shape.

B. Capsules opening irregularly, placed on a columnar or filiform receptacle, and terminating a vein at the margin of the frond, having a transverse ring, and included in an involucre. Fronds delicate, membranaceous.

13. Trichomanes. Involucre subcylindrical, nearly entire. Receptacle usually exserted.

14. Hymenophyllum. Involucre 2-valved. Receptacle rarely exserted.

Suborder 2. Osmundeæ.-Capsules clustered at the margin of a transformed frond or portion of a frond, reticulated, opening by two regular valves; ring almost obsolete. Fronds circinate in venation.

\section{Osmunda.}

Suborder 3. Ophioglosseæ.-Capsules globose, between coriaceous and fleshy, sessile, forming a simple or compound pedunculated spike, distinct from the sterile frond, and opening transversely by two equal valves. Fronds straight in vernation.

16. Ophioglossum. Capsules connate, on a 2-ranked spike.

17. Botrychium. Capsules free, arranged on one side of a pinnated spike. 
Suborder 4. Lycopodieæ.-Capsules without a ring, coriaceous, sessile in the axils of leaves or bracts, 1 celled, 2- or 3-valved. Stems leafy. Vernation not circinate.

18. Lycopodium.

Suborder 5. Isoeteæ.-Capsules without a ring, indehiscent, immersed in a cavity at the base of long subulate radical leaves. Seeds on filiform receptacles. Vernation involute. Aquatic.

19. Isoetes.

Suborder 6. Marsileæ.-Fructification of two kinds. Capsules without a ring, in globose coriaceous involucres near the root of the plant. Vernation involute. Aquatic.

20. Pilularia.

TABLE OF SPECIES AND VARIETIES.

POLYPODIACE两.

POLYPODIEA.

1. Gymnogramme.

1. G. leptophylla. Fronds ternate.

2. Polypodium.

1. P. vulgare. Fronds pinnatifid.

a. var. Cambricum. Fronds broad; segments toothed. 
b. var. bifidum. Fronds forked.

c. var. acutum. Fronds forked and pointed.

d. var. omnilacerum. Segments cut into sharp teeth.

c. var. semilacerum. Pinnæ of usual length, but only divided on the lower part of the frond.

$f$. var. auritum-dentatum. Pinnæ eared.

g. var. auritum. Pinnæ eared and many of them forked.

h. var. attenuatum. Fronds elongated; pinnæ long and narrow.

i. var. bifido-lobatum. All the pinnæ forked. The lower ones eared at the base.

j. var. coriaceo-bifidum. Fronds dwarf, erect, leathery, some of the segments forked.

$k$. var. crenatum. Fronds tall, broad, notched at the margin of the segments, very thin in texture.

l. var. cristatum. The pinnæ crested at the points.

m. var. dentatum. Pinnæ narrow, pointed, and toothed.

n. var. denticulatum. Fronds broad, margin jagged.

o. var. interruptum. Pinnæ varying in length.

p. var. marginatum. Pinnæ jagged and some of them eared; fronds large.

q. var. obtusum. Dwarf fronds and the pinnæe blunted.

r. var. pulcherrimum. Very large fronds; pinnæ deeply jagged in the lower parts.

2. P. Phegopteris. Fronds pinnate; pinnæ pinnatifid.

3. P. Dryopteris. Fronds ternate, glossy. 
4. P. Robertianum. Fronds ternate, mealy.

5. P. alpestre. Fronds bipinnate, lance-shaped.

\section{ASPIDIE E.}

3. Woodsia.

1. W. hyperborea. Pinnæ lobed.

2. W. Ilvensis. Pinnæ oblong.

4. Aspidium.

1. A. Lonchitis. Fronds pinnate.

a. var. confertum. Frond smaller; pinnæ crowded.

b. var. multifidum. Frond forked at the point.

c. var. proliferum. Fronds bearing bulbs in the axils of the lower pinnæ.

2. A. aculeatum. Frond bipinnate; pinnules acutely wedge-shaped at the base.

a. var. lobatum. Fronds rigid, narrow.

b. var. lobatum-acutum. Pinnules attenuated.

c. var. crassum. Pinnules short, thick, overlapping.

d. var. multifidum. Fronds crested at the point.

e. var. micaceum. Dwarf frond and large pinnæ.

$f$. var. acrocladia. Large, erect, crested.

g. var. furcatum. Forked at the points and narrowed.

h. var. interruptum. The pinnæ narrowing to the base.

3. A. angulare. Fronds bipinnate; pinnules obtusely angled at the base, stalked.

a. var. subtripinnatum. Leaflets much indented.

\section{Nephrodium.}

1. N. Thelypteris. Fronds pinnate, of delicate texture; sori near the margin. 
2. N. Oreopteris. Fronds pinnate, glandular beneath.

3. N. Filix-mas. Fronds bipinnate and broadly lanceolate.

a. var. cristatum. Fronds crested at the summit.

b. var. Jervasii. Fronds large; pinnæ long; crest tasselled.

c. var. pumilum. Fronds dwarf; leaflets large in proportion.

d. var. Clowesii. Fronds tasselled at the apex.

e. var. Bollandii. Fronds broad and waved.

$f$. v. abbreviatum. Fronds dwarf; leaflets crisped.

g. var. angustatum. Fronds narrow, crested.

h. var. incisum. Fronds robust, stately, contracting near the apex.

$i$. var. trapeziforme. Fronds golden-green.

$j$. var. recurvum. Margin of leaflets recurved.

$k$. var. giganteum. Fronds very large.

l. var. flexuosum. Rachis zigzag in form.

m. var. erosum. Fronds dwarfed.

4. N. rigidum. Fronds bipinnate, without spinulose serratures, glandular.

5. N. cristatum. Fronds pinnate, pinnatifid, linearlanceolate.

a. v. interruptum. Pinnæ dwarfed and shortened.

b. var. furcans. Pinnæ forked.

6. N. spinulosum. Fronds oblong or ovate-lanceolate.

a. var. bipinnatum. Fronds short, bipinnate.

b. var. validum. Fronds tall; pinnæ concave; leaflets crisped.

c. var. interruptum. Some of the pinnæ dwarfed.

d. var. pigmaum. Fronds dwarf.

e. var.tanacetifolium. Fronds large and triangular; stems arched. 
f. var. Howardii. Upper pinnæ curiously distorted.

g. var. cristatum. Fronds crested.

h. var. glandulosum. Glands much developed.

$i$. var. crispum. Leaflets crisped and waved.

$j$. var. tenerum. Fronds weak and delicaté.

7. N. dilatatum. Fronds ovate, tripinnate; leaflets sharply serrated.

8. N. amulum. Fronds triangular, bipinnate; pinnules concave below.

$a$. var. alatum. Fronds quadripinnate.

b. var. productum. Fronds shorter, less divided.

9. $N$. dumetorum. Fronds ovate, blunt; leaflets broad. 10. N. remotum. Fronds oblong, lanceolate, glossy bipinnate; lower pinnæ distant, stalked.

6. Cystopteris.

1. C. fragilis. Fronds lanceolate, bipinnate; pinnules ovate, acute ; sori central.

a. var. dentata. Pinnules ovate, acute, distant.

b. var. Dickieana. Pinnules broad, obtuse, overlapping.

c. var. angustata. Fronds pointed; pinnules sharply cut.

2. C. alpina. Fronds tripinnate; segments linear.

3. C. montana. Fronds triangular.

\section{Asplenium.}

1. A. septentrionale. Fronds linear-lanceolate 2- or 3cleft.

2. A. Germanicum. Fronds linear, pinnate; pinnæe alternate, narrow wedge-shaped; involucre entire. 
3. A. Ruta-muraria. Fronds bipinnate; pinnules wedgeshaped at the base, lobed; involucre jagged.

4. A. viride. Fronds linear, pinnate; rachis green.

5. A. Trichomanes. Fronds linear, pinnate; rachis black.

a. var. incisum. Pinnæ larger, deeply cut and serrated.

6. A. marinum. Fronds pinnate; rachis winged.

7. A. lanceolatum. Fronds bipinnate, lanceolate; rachis not winged.

8. A. Adiantum-nigrum. Frond bipinnate or tripinnate, triangular ; involucres firm.

a. var. obtusum. Fronds short, blunted.

b. var. acutum. Fronds long, outspread, tapering.

9. A. fontanum. Fronds bipinnate, narrow-lanceolate; rachis winged.

10. A. Filix-formina. Fronds bipinnate, lanceolate; pinnæ lanceolate, pointed; pinnules flat, linear. oblong.

a. var. multifidum. Pinnæe divided at the ends.

b. var. crispum. Fronds curled and puckered in every part.

c. var. incisum. Fronds feathery; pinnules very deeply cut.

d. var. convexum. Pinnules narrow, distinct, linear, convex.

e. var. latifolium. Pinnules broadly ovate, crowded, irregularly lobed.

f. var. molle. Fronds smaller; tapering leaflets oblong, winged.

g. var. marinum. Fronds small, horizontal, elegantly tapering; leaflets oblong, bluntly toothed. 
11. A. Ceterach. Frond pinnate; pinnæ sessile, scaly beneath.

\section{Scolopendrium.}

1. S. vulgare. Fronds strap-shaped, entire.

a. var. crispum. Fronds broad; margin plaited.

b. var. marginatum. Fronds narrow; margin notched and lobed.

c. var. multifidum. Fronds forked one or more times.

d. var. polyschides. Fronds very narrow.

e. var. lobatum. Fronds simply forked.

f. var. ramosum. Fronds forked from the stem.

g. var. cristatum. Fronds crested.

h. var. proliferum. Fronds extremely narrow, consisting of little beyond the rachis.

$i$ var. foecundum. Fronds bearing young plants.

\section{PTERIDEA.}

9. Pteris.

1. P. aquilina. Fronds subtriangular, bipinnate; leaflets sessile, narrow, entire.

a. var. vera. Pinnules pinnatifid.

b. var. integerrima. All the pinnules entire.

10. Cryptogramme.

1. C. crispa. Fronds barren and fertile, tripinnate.

\section{Blechnum.}

1. B. boreale. Fronds pinnate, barren and fertile. 


\section{Adiantum.}

1. A. Capillus-Veneris. Fronds branched; leaflets fanshaped.

DICKSONIEZE.

\section{Trichomanes.}

1. T. radicans. Fronds ovate-pointed, membranaceous.

14. Hymenophyllum.

1. H. Tunbridgense. Pinnæ vertical; involucre compressed, serrate.

2. H. Wilsoni. Pinnæ turning to one side; involucres inflated, entire.

OSMUNDEA.

\section{Osmunda.}

1. O. regalis. Fronds bipinnate, oval; leaflets oblong, entire.

OPHIOGLOSSEA.

16. Ophioglossum.

1. O. vulgatum. Frond entire, oval; spike simple. a. var. angustifolium. Frond narrow.

17. Вотrychium.

1. B. Lunaria. Frond oblong, pinnate; leaflets crescent-shaped, toothed; spike branched. a. v. rutaceum. Frond bipinnate; leaflets narrow.

\section{LYCOPODIACE开.}

18. Lycopodium.

1. L. clavatum. Leaves scattered, incurved, hairpointed; spikes two or more on a stalk. 
2. L. annotinum. Leaves indistinctly 5-rowed, linearlanceolate; spikes solitary, sessile.

3. L. inundatum. Leaves scattered, curved upwards, linear; spikes solitary, sessile.

4. L. selaginoides. Leaves scattered, half-spreading, lanceolate; spikes solitary, sessile.

5. L. alpinum. Leaves in four rows, pressed close to the stem; spikes solitary, sessile.

6. L. Selago. Leaves in eight rows, overlapping one another on the erect, bushy stems; fructifica tion in the axils of the leaves, not in spikes.

\section{MARSILEACE正.}

19. Isoetes.

1. I. lacustris. Leaves erect, bristle-shaped, cellular; * fructification in the base of the leaves.

2. I. Duriai. Leaves slender, spreading.

20. Pilularia.

1. P. globulifera. Leaves slender, rush-like, cylindrical; capsule stalked.

\section{EQUISETACEA.}

21. Equisetum.

1. E. Telmateja. Sterile stems branched, smooth, with about thirty ridges; fertile ones simple, short, with large crowded sheaths, and awl-shaped 2ribbed teeth.

2. E. umbrosum. Sterile stems branched, rough, with about twenty ridges; fertile ones simple, with close-fitting sheaths, having awl-shaped 1-ribbed teeth. 
3. E. arvense. Sterile stems branched, slightly rough, with from ten to sixteen ridges; fertile ones simple, with distant, coarse sheaths, having long pointed teeth.

4. E. sylvaticum. Stems all of one form, with about twelve ridges, and having loose sheaths, with about four blunt lobes; branches drooping.

5. E. limosum. Stems similar, smooth, with numerous slight ridges; the sheaths green, close, having from sixteen to twenty sharp-pointed darkcoloured teeth; branches short, few, often absent.

6. E. palustre. Stems similar, slightly rough, with from six to eight broad, prominent ridges; the sheaths pale, loose, with acute, wedge-shaped, brown-tipped teeth; branches erect.

7. E. hyemale. Stems similar, very rough, with from fourteen to twenty ridges, and having close whitish sheaths, banded with black at the top and bottom; the teeth slender, deciduous; almost branchless.

8. E. trachyodon. Stems similar, very rough, branching from the joints at the base; sheaths with from six to thirteen narrow teeth.

9. E. variegatum. Stems similar, very rough, with from four to ten ridges; sheaths slightly enlarged, green below, black above, with obtuse teeth, tipped by a deciduous bristle; almost branchless. 
Mr. Newman describes ferns as "Acrogenous plants, of vascular structure, which produce fruit without preliminary flowers." He divides Acrogens thus :-

I. Filicales, having distinct leaves, bearing 1-celled capsules, which are encircled by an elastic ring. They comprise :-

1. Rhizophyllacea, in which the leaves are attached to a rhizome.

2. Cormophyllacea, in which they are attached to a cormus or trunk.

II. Osmundales have distinct leaves and 1-celled capsules detached from the leaves, and not encircled by an elastic ring. They comprise :-

1. Osmundacere, the vernation of the leaves circinate, and the trunk woody.

2. Ophioglossaceæ, vernation straight, trunks succulent.

III. Lycopodiales have distinct leaves, and capsules divided by one or more septa. They comprise :-

1. Marsileacea, in which the capsules are attached to the rhizome.

2. Lycopodiacece, capsules seated in axils of the leaves.

IV. Equisetales have no leaves, but consist of an articulated-branched stem. They comprise :-

1. Equisetacea. The fructification forming terminal spikes.

The special point of distinction in this plan of arrangement is that drawn between the rhizome and the caudex. In the arrangement we have followed, we regard them as identical.

Mr. Newman draws a decided distinction between the creeping caudex of Polypodium vulgare and that of Polypodium Dryopteris, the caudex of the one being naked 
and the stems scaly, and in the other, the caudex scaly and the stems comparatively naked. In the Rhizophyllacea division, the caudex is scaly and never terminates in a frond, and the fructification follows the development of the frond. In the Cormophyllacea the caudex is naked, and always terminates in a frond; it creeps underground, and in that respect partakes more of the nature of a root than a stem. This division between the characteristics of the caudex divides many genera cutting Polypodium vulgare off from its allied species, and bringing Nephrodium Thelypteris to their side. 


\section{POLYPODIACE $Æ$.}

POLYPODIEAE.

\section{GYMNOGRAIMIME.}

Gen. Char. "Sori linear, elongated, on forked free veins, destitute of involucre." - Sir W. Hooker.

\section{Gymnogramme leptophylla. Small Gymnogram.}

Sori without cover. Fronds of two kinds, barren and fertile.

The Small Gymnogram is an inhabitant of Jersey, it grows there on sunny banks, and is not unfrequent, but, being an annual, it can only be found during the summer and autumn. Its name is composed of two Greek words which signify naked and writing, and refers to the absence of cover, and to the branching form of the seed-masses resembling Hebrew letters. The barren fronds have from one to three fan-shaped pinnules, each lobed and indented. The fertile fronds have a pale shining brown stipes, and the pinnules, though of the same

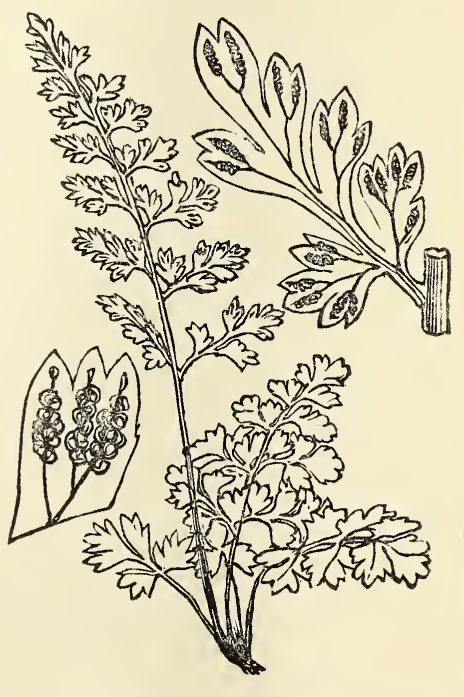
shape as those of the barren frond, are less expanded. The veins are doubly forked, so as to send a branch into 
each lobe of the pinnule, and the fructification following the course of these veins, becomes branched also, and as it ripens covers nearly all the under part of the pinna.

Its only ascertained British habitat is the island of Jersey, where it has been found near St. Helier, St. Aubyn, and St. Lawrence, by Mr. Ward, and many a less noted fern-seeker. It has long been known as a native of southern Europe, and has also been found in Abyssinia, Persia, Mexico, and at the Cape of Good Hope.

The Gymnogram should be provided with a very sheltered nook in the fernery, or, better still, with a corner in the greenhouse, or the protection of a Wardian case. Mr. Johnson recommends a compost of equal parts of leaf-mould and peat, with a little sand, and in this it will flourish if supplied with a moderate quantity of water during its growing season. The fronds are of a yellowish-green, and this golden shade, together with the delicate form of the minute fern, give it the charm of contrast when growing among the ordinary inhabitants of the fernery.

Insignificant as is our little native Gymnogram, it represents a family important in numbers and famous for beauty. To it belongs the group of Gold and Silver ferns, which form the pride of conservatories, the orange, yellow, sulphur, or snow-white powder covering the under side of the much divided fronds, and investing them with the charm of gay colouring in addition to that of elegance of form. 


\section{POLYPODIUM.}

Gen. Char. "Sori dorsal, subglobose or oval, destitute of involucre. Veins free (as in all the British species) or anastomosing." - Sir W. Hooker.

\section{Polypodium vulgare, L. Common Polypody.}

Caudex stout, widely creeping, scaly. Fronds ovate-oblong. Sori round, placed in a row on either side the mid-vein.

The name of this well-known fern is formed from two Greek words, polys, many, and pous, podos, a foot; and is applicable because of the many rootlets thrown out from the caudex.

The form of the frond is very variable,-we sometimes find it eighteen inches long, while the plants that grow on old walls have often fronds not more than three inches in length. The caudex creeps horizontally, becoming interlaced and matted when left long undisturbed, and densely clothed with narrow, glossy brown scales. The frond is pinnate, the pinnæ nearly equal, opposite, and slightly waved or jagged at the margin. Each pinna has a midvein, from which branches issue, and the fructification is

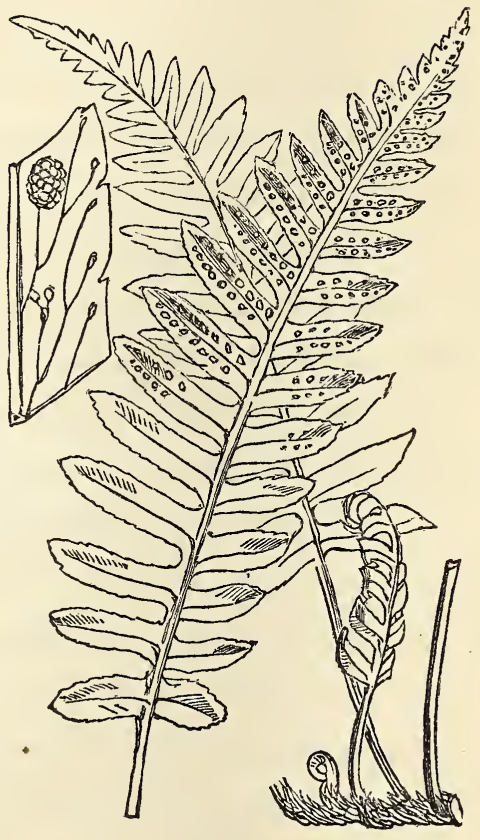
situated at the point of the side veins.

Common as this fern is, and familiar to every one who has eyes to see with, it never fails to be noticed with favour. Lending to the decaying trunk a new 
verdure, to the crumbling wall a fresh grace of contour, it adds charm to both, while its continued greenness makes it doubly acceptable in winter, when most of its compeers have yielded to decay. The chestnut scaliness of its quaint caudices forms as pleasing a contrast to the prevailing green of the summer woods, as the verdure of the fronds does to the iron grey of winter; and thus the "Polypody of the Oak" is beloved at all seasons.

This is a fern belonging to temperate climates; it is unknown in the tropics, but frequents North America, Canada, and the Cape of Good Hope.

There are interesting varieties of this fern, which are much valued in ferneries.

1. Polypodium vulgare Cambricum, or Welsh Polypody. Here the frond is broad, and the pinnæ toothed. Ray first mentions this fern; he has it from Powis Castle, in Glamorganshire.

2. Polypodium vulgare bifidum, or Forked Polypody. In this variety each pinna is forked at the point; it has been found in Yorkshire and Monmouthshire.

3. Polypodium vulgare acutum. The point of each segment tapering; a scarce variety.

4. Polypodium vulgare omnilacerum. All the pinnæ cut into sharp teeth, and divided halfway to the midrib; a variety of the Cambrian group.

5. Polypodium vulgare semilacerum. The pinnæ of usual length, but only divided on the lower part of the frond, where the segments are very deeply cut.

6. Polypodium vulgare aurito-dentatum. A smallfronded variety, each pinna furnished with an ear, and dentate at the margin.

7. Polypodium vulgare auritum. Smaller still in its habit of growth, eared like the last, and many of the pinnæ forked. 
8. Polypodium vulgare attenuatum. 'The fronds elongated, the pinnæ long and very narrow, placed alternately on the rachis, and at a considerable distance from each other, and sprinkled in the upper part by large sori. Introduced by Mr. Wollaston, of Chiselhurst.

9. Polypodium vulgare bifido-lobatum. A Somersetshire variety, resembling the last in the forked character of the pinnæ, but with the additional characteristic of an ear on the anterior base of the lower ones.

10. Polypodium vulgare coriaceo-bifidum. A very peculiar variety, of leathery texture, erect habit, and dwarf statures. Like its neighbours, its lower lobes are bifid, and the margin often slightly jagged. The sori are very large, and situated so near together as to be almost confluent, and from the erect habit of the fern the plentiful yellow fruit is much exposed, giving a golden appearance to the fronds. The plant described by Mr. Lowe grew on a wall near Malton.

11. Polypodium vulgare crenatum. A Welsh and Irish variety, in strong contrast to the last described. Here the fronds are tall, broad, and of thin herbaceous texture, and the margins slightly notched. It would be a favourite variety only that its permanence is not to be relied on.

12. Polypodium vulgare cristatum. The pinnæ adorned by much divided points.

13. Polypodium vulgare dentatum. The pinnæ narrow and pointed, but with the additional peculiarity of being deeply toothed.

14 Polypodium vulgare denticulatum. Broad fronds, margins jagged, whole appearance creepy.

15. Polypodium vulgare interruptum. Curious from the varying length of the pinnæ, which look as if some of 
them had been interrupted in their growth; a rare variety.

16. Polypodium vulgare lobatum. Fronds large; pinnæ eared on the upper edge.

17. Polypodium vulgare marginatum. Pinnæ jagged, sometimes doubly, on the margin, and sometimes eared; fronds large.

18. Polypodium vulgare obtusum. A dwarf variety, with entire and blunted pinnæ.

19. Polypodium vulgare pulcherrimum. A Milnthorp variety, justly called "most beautiful." Nearly a foot high, and broad in proportion, bipinnatifid in the lower part, and deeply jagged above; the lobes rounded and their texture thick.

The Common Polypody, both in its simple form and in its varieties, is a good inmate of the fernery. It is easy to bring a mat of its twisted caudices, and the moss cleaving thereto, from the woods to the artificial rockery, where a thick layer of leaf-mould and cow-manure, mixed with water and applied to the surface of the stone, like mortar, at once secures the adherence of the new immigrant and its ample nourishment; while careful watering will prevent the fainting of the plant before its delicate rootlets get hold of the crevices of its new home. The varieties are less calculated for growing on stone or wood than our familiar friend of the wall; it is better to plant them in leaf-mould, and take no liberties with them.

\section{Polypodium Phegopteris, Linn. Pale Mlountain Polypody.}

Sori round, placed on the margin of the leaflets. Stem tall and scaly. Frond triangular. Caudex long and creeping, sending out thread-like roots.

The name of this fern is derived from two Greek 
words, phegos, a birch-tree, and pteris, fern. Neither this nor the popular English name Beech-fern has any true foundation, for neither does the fern resemble either of the trees named in form or colour, nor especially avail itself of their shade. The name given by Sir W. Hooker, "Pale Mountain Polypody," is infinitely more appropriate.

The caudex of this fern creeps and interlaces; it is very brittle. About May, slender stems arise from the caudex, bearing pale hairy fronds; these attain their full growth with great rapidity, reaching a height of from six inches to one foot. The stem is about twice the length of the leafy part of the frond; it is slender and brittle, and bears a few transparent, colourless scales near its base. The stem is generally bent at the commencement of the leafy part at a blunt or right angle. The leafy part is triangular in form, terminating in a slender point. It is pinnate, each pinna being beset with oblong leaflets; the lowest pair of

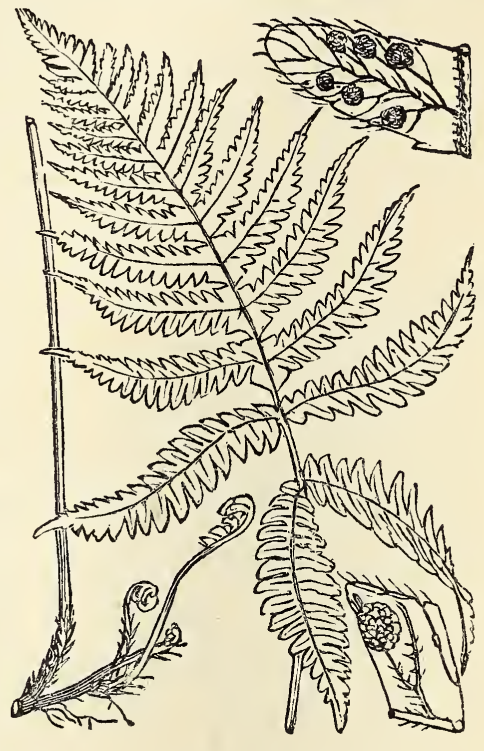
pinnæ bend forward so as to give a very marked character to the fern. The colour is pale green, with a dull shade imparted by the hairiness.

The Pale Mountain Polypody grows freely where it once establishes itself, generally forming a crowded plantation of jostling fronds of varying height and size. It frequents cool mountainous districts, in England and Scotland and Ireland, always preferring a damp soil, 
and flourishing especially in the neighbourhood of waterfalls. It is an elegant fern, making a charming miniature landscape in contrast with moss, wild flowers, and the stumps of underwood. It grows freely in woods, among the highlands of Scotland, the dales of Yorkshire and Derbyshire, and the combes of Somersetshire.

Mr. Lowe describes a variety of the Beech-fern found in a lane very near to Ambleside. The soil there is damp, and the bank pretty high. The fern is irregular in its divisions, many of the lobes of the pinnæ being frequently and deeply divided. The variety does not seem to have been found elsewhere. The near neighbourhood of Stock-ghyll Force proves that the moisture so much loved by every variety of the Beech-fern is within reach, and if any doubt remained, Mr. Lowe's assertion of the presence of Primula farinosa on the same bank would prove to us the dampness of the situation. Mr. Newman has changed the name of this and the two following Polypods to Gymnocarpum, separating them on account of their creeping caudex, but we follow the example of Sir William Hooker in retaining the familiar name.

The Beech-fern is one of the most desirable ferns for cultivation, and flourishes well when the ground is well prepared for it. A shady situation is a sine quâ non; when in a wild state it dwindles to an unhealthy size if its shelter is withdrawn, and in cultivation it declines life altogether if exposed to sun and wind.

Mr. Johnson recommends that the ground intended for the future home of the fern should be excavated to the depth of one foot. At the bottom a thick layer of bog-moss should be placed, then a layer of porous stone, broken crocks, etc., leaving six inches to be filled with a 
compost of fibry peat, leaf-mould, and silver-sand. The plant is well worth the trouble of such treatment, its form and tint being alike acceptable in the ornamental bouquet and in the drawing-room vase.

This fern is found among the Swiss Alps, in North America, Canada, and even Iceland and Siberia.

\section{Polypodium Dryopteris, Linn. Tender Three- branched Polypody, or Oalk-fern.}

Sori in two rows, near the margin of the leaflets. Caudex long, slender, widely creeping. Stem long, thin, and scaly. Fronds 3-branched, twice pinnate, and of thin texture.

The name Dryopteris is derived from drys, the Greek for oak, and pteris, fern. There is as little significance in the name as in that of the last species, except that the spreading branches may bear some resemblance to those of the tree in question.

The caudex is slender, brittle, and creeps to a great distance, often extending its ramifications over half an acre of ground; the stem is thrown up in May, and resembles a slender wire, crowned with a tiny verdant ball. It soon becomes tinged with purple or brown. Brown scales accompany both the young shoots of

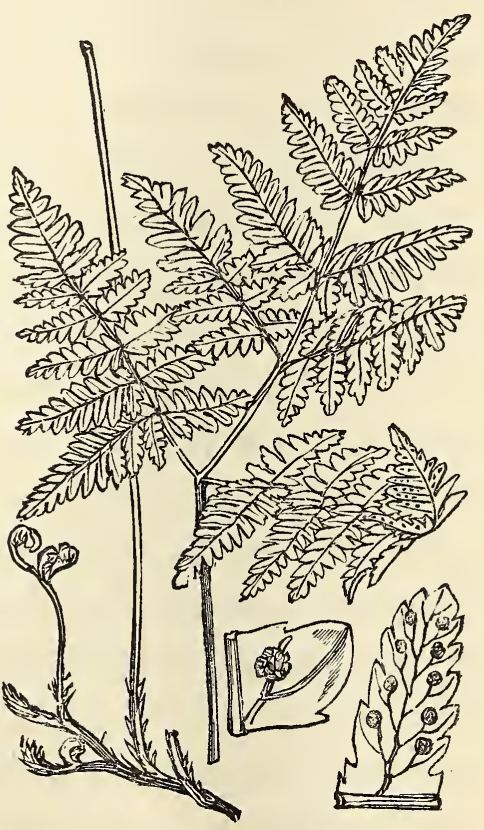
the caudex and the base of the slender stem. The leafy part of the frond is about two-thirds the length of the 
stem, which bends at its juncture with the branches; the form is pentangular, each of the three branches forming an acute triangle, the bases of the lowest branches add two short sides to what would otherwise be a triangular frond.

Each of the three branches is furnished with opposite rows of pinnæ, or rather of pinnules, the side branches being themselves pinnæ, and these again are beset by oval leaflets. The colour of the frond is of a very bright green, glossy, and delicate in texture. The sori are produced in abundance on the older fronds, while the younger ones attain a lower height, have more outspread leaflets and more angularly bent stems.

Nothing can exceed the beauty of a flourishing colony of this oak-fern, growing, as we often see it, under a birch grove upon the bank of some Yorkshire streamlet, or in the heart of some shady Somersetshire combe. A myriad wiry stems, shading to every tint of purple and brown, rise from the branched caudex, which pushes its arms freely among moss and roots and half-decayed leaves, enjoying perpetual moisture. The stems springing from the old branches of the caudex rise half a foot in height, bearing their leafy three-branched crown proudly, its verdant standard floating from the bluntangularly bent stem, and clothed underneath with a rich harvest of brown sori. The young shoots of the caudex bear weaker stems, the leafy part of the frond lying almost horizontally, from the sharper inclination of the deflexion of the stem, thus making a kind of underwood of fronds, over which the fully-developed ones tower in conscious dignity. All the fronds are of a rich green colour, but the lighter shade of the young ones is like sunshine itself, and all the verdant penta- 
gons, young and old, are so slenderly mounted on their frail wires that they quiver at the touch of the dragonfly or the whisper of the faintest zephyr. It perishes in the first frosts. This fern grows abundantly in England and Scotland, but is rare in Ireland. It likes mountainous situations, and loves a moist locality ne rly as well as the Pale Mountain Polypody. Not only does it flourish, like its congener, in the mountain grove, but among the stranded boulders on the margin of the stream, and in crevices of stone where the overhanging rock affords it the needful shelter, and the winds bring it its favourite bed of dead leaves. It is found in Norway, among the Swiss Alps and Spanish Pyrenees, the West Himalayas, Japan, North America, Siberia, and Greenland.

This is an excellent plant for the fernery. When placed under shelter from sun and wind, in a compost of peat earth, leaf mould, and silver sand, it not only takes kindly to its new home and rewards its cultivator by throwing up verdant fronds, but in the course of the second or third season the caudex begins to creep in all directions, and form graceful landscapes as in its native wilds. We have seen lines of stems of the Oak-fern rising along the ledges of an artificial rockery, like miniature Scotch pines in the Highlands, and groups congregated together under shelter of some carefully-placed slab of limestone, like a tiny grove of birch among rocky heights, and all, both the quaintly scattered fronds and the sheltering group, natural colonists from a bundle of plants located there some three or four years back. 


\section{Polypodium Robertianum, Hoffm. Rigid Three-branched Polypody.}

Sori like the last. Caudex creeping. Stem firm, beset with glands. Frond triangular.

The name of this somewhat doubtful species is derived from that of the Geranium Robertianum, or Herb Robert, whose scent that contained in the glands of the fern resembles. It was called formerly Polypodium calcareum, that name referring to the limestone districts, the invariable habitat of the fern.

The caudex of the Polypodium Robertianum creeps widely, and in this respect, as well as in the sori, it is not distinguishable from the Oak-fern; indeed, so great is the similarity between the two, that many high authorities consider this merely a variety of the former species, and have figured the one for the other. Hoffmann lays principal stress on the glandular down covering the fern as a mark of distinction, this feature being wholly absent in the Oak-fern. Sir W. Hooker, though deciding that "Polypodium Robertianum is a very doubtful species," yet concedes that its habit is very different to that of $P$. Dryopteris. The stems are much firmer, less deflexed at the juncture with the frond, and different in colour, being of a dull green instead of tinged with brown or purple; the branches are more upright, overlapping one another so as to avoid the divergence of the form of the frond towards a pentagon. The colour of the frond is quite different from that of the Oak-fern, being dull in tint, as if a grey misty light were shed over it, while the other glowed in sunshine. This dulness of colour is in part ascribable to the secreted glands which cover the fern as with down, but the actual colour 
is dull in itself. Mr. Moore regards the two as entirely aistinct species, and in proof thereof cites a peculiar habit in the infant frond, each pinna being rolled in separately, instead of all pertaining to each of the three branches being packed in one ball, as in the case of $P$. Dryopteris. We would venture to add, from our own observation, that the Polypodium Robertianum grows, both in its native woods and under cultivation, in a more dense and compact style than in P. Dryopteris, forming clusters of fronds closely packed together, like the Pale Mountain Polypody, rather than fanciful lines and light groups like the related species.

This fern is never found except on a limestone soil. It has been frequently found on Ingleborough, and we know it well as an inhabitant of the Yorkshire dales and Somersetshire combes.

It succeeds well in the fernery, requiring a compost like its fellows, and a free supply of water during the growing season.

\section{Polypodium alpestre, Hoppe. Alpine Polypody.}

(Athyrium Rhceticum, Roth; Polypodium flexile, Moore.)

Caudex oblique. Stem short and scaly. Fronds lanceolate. Sori round, marginal.

The caudex of this fern is horizontal or oblique, bearing a crown-shaped tuft of fronds at the point of each branch. The stems are enlarged at the base, and very short, because of early commencement of the leafy portion of the frond; they are covered with large brown scales. The frond is lanceolate and bipinnate, the leaflets are oblong and unstalked.

This fern is very distinct from all other members of 
its genus, but it has been frequently confused with the Lady-fern, which it resembles in form and habit. It is

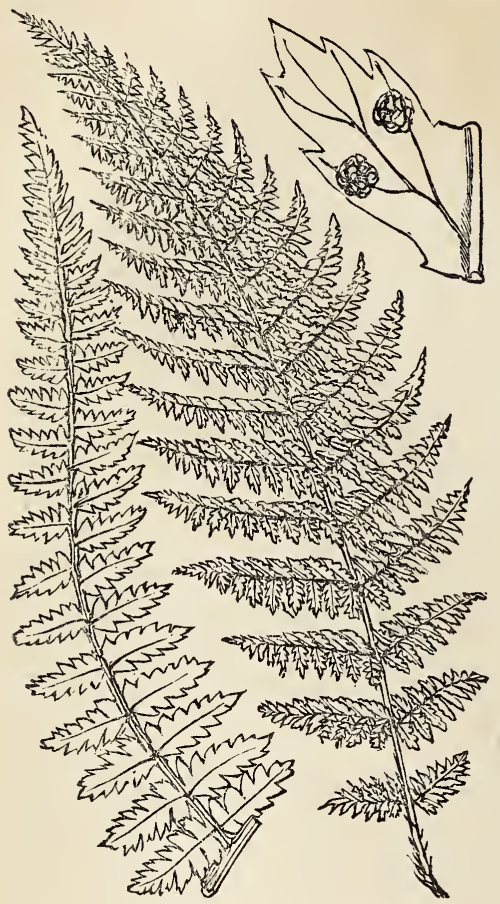
distinguished by its naked seed-masses.

The Polypodium alpestre was first discovered in England by Mr. H. C. Watson. He found it in Forfarshire and Inverness-shire in 1841, and it has since been discovered elsewhere in the alpine parts of Scotland. It is found in Norway, Lapland, Russia, Grermany, and N.W. America.

In cultivation, the place for it should be excavated, and freely drained by means of a thick layer of porous stone and broken crocks; it should then be planted in the usual compost of peat-earth, leafmould, and silver-sand, receiving a good supply of water in the early summer. Such is Mr. Johnson's mode of treating the fern.

A well-marked variety, with shorter pinnæ, is known as Polypodium alpestre, var. flexile; its texture is extremely tender, its texture is extremely narrow, and not only are its pinnæ shorter but considerably fewer in number, they extend further down the stem than in the normal form, and are comparatively distant; the pinnules are toothed. It is found in the Clova mountains.

Polypodium alpestre, var. tripinnatum. Varies from the normal form in an opposite degree. Its fronds are 
large and tripinnate, the pinnules long-ovate. Aberdeenshire is its locale.

Polypodium alpestre, var. lanceum, is also a large variety, more elongated than the last, and with the segments bluntly toothed. It is found both in the Clova mountains and Aberdeenshire.

Polypodium alpestre, var. laciniatum, has the narrow and elongated form of flexile, but, instead of the pinnæ being distant, they are very closely placed, and the margin is deeply toothed.

\section{WOODSIA.}

Gen. Char. Roundish sori, having an indusium, or wrapper, fixed beneath, which tears into hair-like fragments at the edge.

\section{Woodsia hyperborea. Round-leaved Woodsia.} (Woodsia alpina.)

Caudex short and thick, upright. Roots very numerous. Fronds lanceolate, from two to six inches in height, hairy, pinnate; the pinnæ oval, and cut at the edge into rounded lobes. Stem chestnut-coloured and glossy. Esq.

These ferns are named in honour of Joseph Woods,

The Round-leaved Woodsia renews its fronds each spring, the old ones having perished in the frosts. Both the British species have an articulation in the stem, a short distance from its juncture with the caudex, and here the partition is made on the death of the frond. The form of the frond is linear, that is, long and narrow, its upper surface is smooth, but both hairs and scales are scattered underneath.

This is a pretty and elegant little plant, but is valued more for its rarity than its beauty. It has been found 
in one Welsh and two Scotch counties, but always at high altitudes. Mr. Backhouse, one of our most successful fern-seekers, had the satisfaction of finding it upon the Breadalbane Mountains. He rejoices in having discovered what he calls "the home" of the Woodsia hyperborea. "Just think," he writes, "of luxuriating in the sight of tufts bearing sixty-five, eighty, or even a hundred fronds, from two to four inches high! On one ledge of rock I counted seven tufts, all visible without moving a step. Some are difficult to reach, even dangerous. One most luxuriant tuft remains in a conspicuous position, quite near enough to show its true character, but guarded by crags that threaten almost certain destruction to any one who dares attempt to touch it. The erect dense tufts of silvery-green narrow fronds are very diverse, both in habit and appearance, from those of Woodsia Ilvensis, of which we found fourteen plants in less than an hour, on the Dumfriesshire Mountains, a few days afterwards."

It grows in Sweden, Lapland, Norway, Arctic America, the Swiss Alps, the Spanish Pyrenees, the Punjab, and in Greenland and British North America.

Some writers term it the Alpine Woodsia.

In cultivation this fern requires a compost of peatearth and leaf-mould, with a large proportion of charcoal, porous stone, and silver-sand. Its treatment should be like that of the Pale Mountain Polypody, with drainage of bog-moss and broken crocks. The additional protection of a few small pieces of stone placed firmly about the base of the plant is prescribed by $\mathrm{Mr}$. Johnson for both the Woodsias. 


\section{Woodsia Ilvensis, Br. Oblong Woodsia.}

Caudex short and thick. Roots numerous and matted. Fronds from 2 to 6 inches in height, tufted, compact, lanceolate, and pinnate. Leaflets oblong, the margin narrowly lobed. Stem chestnut, glossy and scaly. Sori on the margin of the leaflets.

The name is derived from the Isle of Elba, where this fern was first discovered.

This dainty little fern parts with its fronds in the same manner and under the same circumstances as its sister species $W$. hyperborea. The fronds grow in a tufted form; the texture of the pinnæe is thick, the colour dull, they are hairy above and below; the stem is covered with slender scales of a reddish hue, which impart their tint to the whole frond.

This species, though sufficiently rare, is found in several British habitats, as upon Snowdon, the Breadalbane

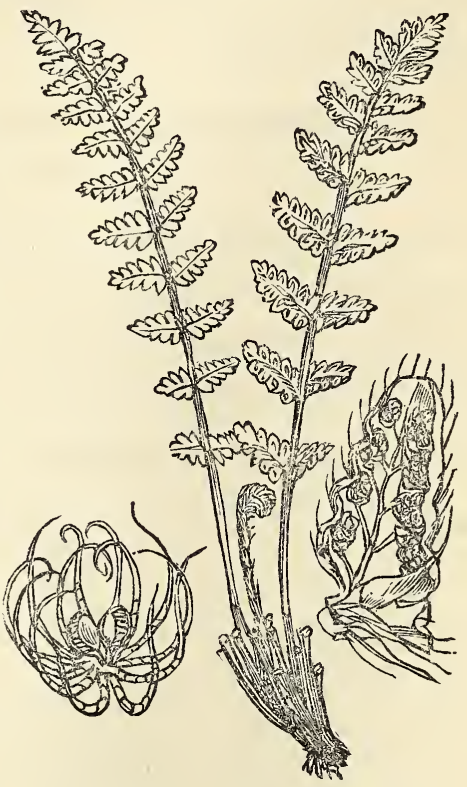
and Clova Mountains, and the hills of Westmoreland and Durham. Mr. Backhouse found it upon the Falcon Clints, in Teesdale, but last year we sought it there in vain. The Cystopteris fragilis grew there in abundance, as he describes it, at the foot of many a bush of Bird-cherry, but no single frond of the Woodsia could we descry. He has also found it growing freely upon the Dumfriesshire mountains, as he states in a letter to the 'Phytologist.' 
Its foreign homes extend over the same regions as its compeer, but include some extra leagues southward.

When placed in the fernery it requires a compost prepared, as for the last species, with the same care in drainage and the same protection around the caudex.

\section{ASPIDIUM.}

Gen. Char. Sori round, covered with a round involucre attached by the centre. Veins simple or forked. Fronds lanceolate, rigid, spiny.

\section{Aspidium Lonchitis. Alpine Shield-fern, or Holly-fern.}

Caudex thick, firm, oblique, scaly. Stem short and scaly. Fronds 6 to 18 inches high, narrow, erect, rigid, densely tufted, pinnate. Leaflets sickle-shaped. Sori in two rows on the leaflets, on the upper part of the frond.

The name is derived from the Greek lonchitis, "re-

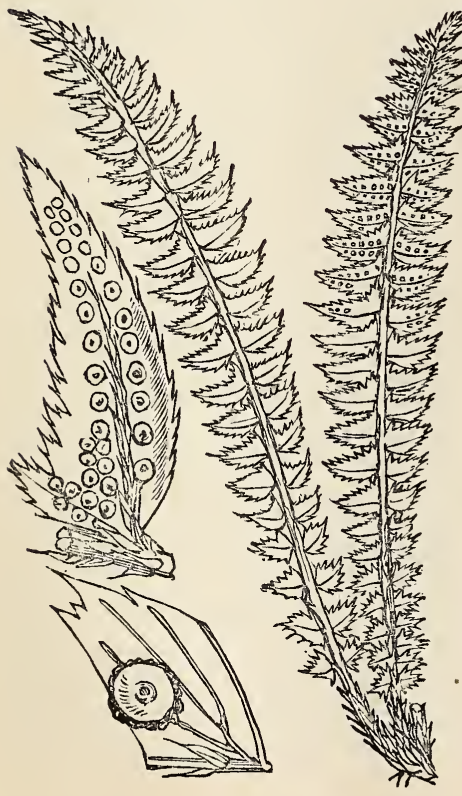
sembling a spear."

The root is large, black, and strong; the caudex thick and tough; the fronds spring from the crown of the caudex in a circular form, bending outwards when growing freely, and forming an elegant basket shape. The stems are short, furrowed in front, they appear early in spring, and the fronds attain their full growth in September. The pinnæ are dark green and glossy, crescent-shaped from an ear at the base, and beset with 
sharp spines, they are generally crowded so as to overlap one another, but this is a variable feature. We saw Welsh specimens last year where the pinnæ were far enough apart to be quite free of one another. Mr. Lowe describes an Irish form of this fern, which he calls Polystichum Lonchitis, var. confertum, it is smaller in size and the pinnæ are numerous and crowded, overlapping one another so that the ear at the base of the one pinna is hid by the upper lobe of its neighbour.

Aspidium Lonchitis, var. multifidum, is forked at the point.

Aspidium Lonchitis, var. proliferum, produces buds in the axils of the lower pinnæ.

Both these varieties are of very rare occurrence.

This fern is sparingly distributed over our alpine districts, being occasionally found among the mountains in the lake district of England, and in similar situations in Scotland and Wales. It is very rare in Ireland.

Mr. Backhouse describes this fern as growing on Ben Lawers and the Breadalbane mountains, "abounding at an elevation of 2000 feet and upwards, frequently associated with Polypodium alpestre and a dwarf Lastrea. Mr. Newman found it in Wales, in a curious chasm called Cwm Idwal, the base of which is filled by a sheet of water, the Llyn Ogwen. He says :- "In the lake grow Isoetes subularia and Lobelia, on the broken ground around several species of Lycopodium, Allosorus crispus, Cystopteris fragilis, and Hymenophyllum unilaterale, and above, Polystichum Lonchitis, Asplenium viride, Rhodiola rosea, Thalictrum alpinum, and Anthericum serotinum, whilst higher up still, Woodsia Ilvensis and Lycopodium annotinum flourish."

The Holly-fern is a native of Greenland, North Ame- 
rica, the United States, and the mountains of Portugal, Italy, Switzerland, and Greece.

When successfully treated, it forms an ornamental addition to the rocky fernery; but no fern is more difficult to naturalize. The half-starved-looking plants which are generally pointed out with so much pride in the fernery, scarcely bear a resemblance to the free-growing crowns of glossy fronds which the same fern bears in the Swiss Alps. Mr. W. Reeve grew it successfully in a coal-house, where it was shaded and kept moist; it was planted in a compost of loam, peat, and sharp sand.

Mr. Johnson recommends a shaded situation, good drainage, and some moisture; but he says, it should be covered with a glass for some time after it is planted, and care must be taken to plant it very firmly.

\section{Aspidium aculeatum, var. lobatum. Narrow Prickly Shield-fern.}

Caudex short, stout, upright, knotted, densely scaly. Stem very short. Fronds rigid, tough, narrow, lanceolate, bipinnate. Pinnæ pointed, alternate, spiny, glossy. Leaflets large, sharply serrated, enlarged at the base, so as to form an ear. Sori in two rows near the mid-vein.

Many botanists consider these ferns three distinct species, and many regard them as three varieties of the same. Mr. Moore makes two species of them. Sir W. Hooker has specimens of every intermediate grade between the three in his herbarium, so pronounces them mere varieties.

This fern, be it a species or only a variety, has some strong distinctions. The caudex is large and tufted; the stems beset with scales half an inch long; the fronds 
are narrow in outline and grow more obliquely; the leaflets larger than in its fellows, of a stiffer texture and darker colour, and they merge their bases in the stem.

Mr. Francis tells us that from Ray downwards it has been admitted as a species by reliable authorities; he lays much stress upon "the shorter, more crowded, and less scaly pinnæ." He says that it prevails in Scotland and the North of England, which we could cite numerous authorities to confirm, that towards mid-England it loses itself in aculeatum, which, in its turn, merges in angulare in the south. There is no doubt that the last-named is as

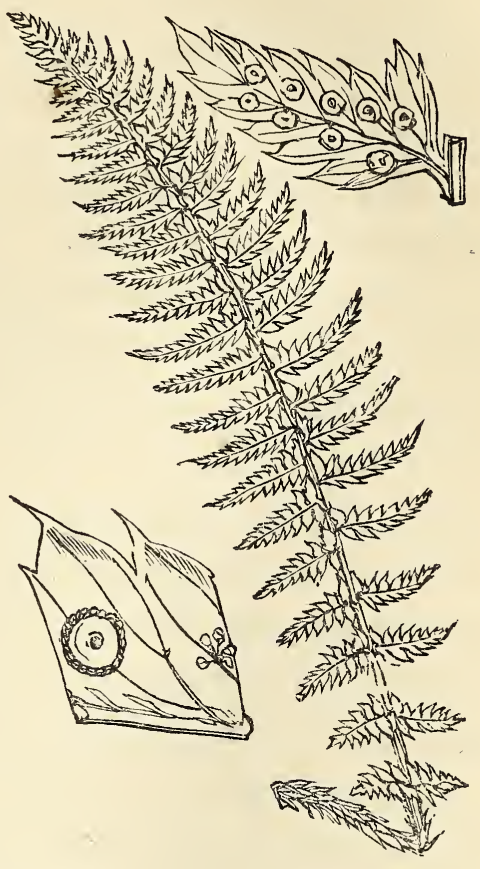
abundant in the genial climate of Kent as lobatum is in the northern woods.

This is a handsome fern, welcome to the eye, both in its wild home and in the fernery. Its fronds grow in a crown, but they bend backwards so much that some of those on each well-grown plant become nearly horizontal. It is evergreen in shady situations, and its firm texture can bear a blast better than any other of our native ferns. This gives it a good claim to a place in the fernery, for it forms an excellent shelter for more delicate species. No draught should be allowed admittance to a fernery, but if there is any corner that must necessarily be exposed, let it be the home of the brave lobatum. 


\section{Aspidium aculeatum, L. (Polystichum). Common Prickly Shield-fern.}

Caudex short, knotted, scaly, upright. Fronds 1 to 3 feet, lanceolate, bipinnate, tough. Pinnæ pointed, alternate. Leaflets close, ovate, spiny. Sori in two rows near mid-vein.

The name aculeatum refers to the sharp teeth on the margin of the leaflets.

The root of this fern is long and spreading, and penetrates so deeply into the earth, entwining with the roots of the brushwood amongst which it delights to grow, that it is very difficult to transplant it. The caudex is large and woody, densely covered with large rust-coloured scales; the stems are thick and short, very scaly, as also when they traverse the leafy part of the frond, the very pinnæ have scales on their stems. The fronds are lanceolate in form, broad in the shoulder in the best-grown plants, 2 feet in height and upwards, erect or slightly bending; the pinnæ are alternate, of harsh texture, their upper surface dark, their under a paler green, very glossy and close together. Both in aculeatum and lobatum the fructification is only upon the upper part of the frond.

There is a narrow attenuated variety called by $\mathrm{Mr}$. Lowe Polystichum aculeatum, var. lobatum acutum, one with very short leaflets of thick texture, and so closely placed as to overlap one another, var. crassum, both of which are rare.

Aspidium aculeatum, var. multifidum, was found in Suffolk by Mr. Wollaston, and in Somerset by Mr. Elworthy; its peculiarity is that the apex of the frond is crested like Filix-mas cristata and Filix-foemina cristata. The variety micaceum, of Barnstaple, is called from the kind of rock on which it grew. It is a dwarf form, both 
short and narrow, the pinnæ much developed in comparison with the size of the frond, the lowest pair having an ear-shaped lobe upon a footstalk.

Aspidium aculeatum, var. acrocladon, is of large size, tall, and crested; it grows in Devon.

Aspidium aculeatum, var. furcatum, has the points of the frond forked and narrowed; it attains a good height, and is found in Devon. Var. interruptum is characterized by its pinnæ narrowing to the base; they are placed alternately on the rachis, and towards the middle of the frond the leaflets are absent or much dwarfed in size.

Mr. Lowe gives six other varieties, but their difference from those already described is not material.

An early habit in the growth of the young fronds renders this plant very elegant. The curved apex of the frond bends backward as soon as it attains a few inches in height, so as to resemble a shepherd's crook. The fronds are evergreen in a sheltered situation, so in the early summer we find a stout guard of firm full-coloured old fronds, with a slender circle of young ones growing up in their midst, bending in every graceful variety of the line of beauty, and wearing spring's own hue of tender green. The fronds attain perfection in July, and ripen their seed in September. This fern often fixes itself in a perpendicular bank, from whence its woody caudex projects in a horizontal position. Thus its verdant fronds spring forth at every possible angle, and show in strong contrast against the grey or iron-tinged rock, or the dark-coloured stump. The distinction of aculeatum from angulare depends mainly on the larger size of the leaflets, and on the presence of ears on more than one of the inferior pinnules. 
Aspidium aculeatum is found commonly in most of our woodland districts.

This fern is very easily managed in cultivation, and, though it is scarcely so hardy as lobatum, it bears exposure pretty well. It requires the usual accommodation of good drainage and a fair allowance of sand and peat, and thus treated it is a very satisfactory member of the fernery, stately in its growth and continuing green all the winter. These are the hardiest of our native ferns, and we have Mr. Newman's authority for saying that they will flourish well even in a London atmosphere.

\section{Aspidium aculeatum, var. angulare. Angular- leaved Shield-ferm.}

Caudex short, stout, knotted, densely scaly. Stem short, stout. Frond 1 to 3 feet long. Leaflets small, close, ovate, spiny, those at the base larger than the rest. Sori in two rows.

The caudex in this fern is woody and-trunk-like, throwing up circular tufts of stems, which are longer than in the last described, and equally covered with rusty scales. The pinnæ are alternate, but are less close to one another; the whole frond is lanceolate in form, broader than its co-varieties, and of a softer texture than theirs; it is more shaggy, the leaflets smaller, more numerous, each one rounded at the base, with a lobe or ear. This fern also retains its verdure through winter when not too much exposed.

This fern appears in the same series of varieties as the last described.

Var. acutum has the pinnules eared and stalked.

Var. tripinnatum is easily distinguishable by the position of the pinnæ, which lie horizontally one over an- 
other, like the steps of a ladder. (We take our description from the notes of Mr. Lowe.)

Var. biserratum is very elegant in appearance, drooping much; its fronds broad; its pinnules large, deeplyserrated, and feathery. Jersey is its home.

Var. decompositum is in strong contrast, its leaflets remarkably small.

Var. aristatum is slender, the pinnæ not crowded; it is named by Mr. Wollaston. Both it and the succeeding one are viviparous or bud-bearing, which buds put forth fronds while still upon the parent plant.

Var. proliferum. Narrow and graceful.

Var. dissimile. The pinnæ varying in size, and the rachis very scaly.

Var. truncatum. The points both of the fronds and the pinnæ blunted; the pinnæ short, with few pairs of leaflets, the terminating leaflet fan-shaped.

Var. depauperatum. Dwarfed, the leaflets starved and deformed.

Var. grandidens. Dwarfed, narrow, lance-shaped.

Var. aculeatoides. Narrow, but very elegant.

Var. imbricatum. Resembling lobatum, but more graceful.

As the mountain woods favour lobatum, so do the southern groves angulare. Right gracefully does it flourish in many a Kentish park and hedgerow, grown in its normal form of a crown where the space is free around it, while in the deep shady lanes its plentiful fronds bend one over another in luxuriant abundance, like the feathers in an ostrich's tail. No fern can lay a stronger claim to favour than this for its evergreen habit, its unsurpassed grace, and its readiness to accommodate itself to each new habitat. 
There is a variety of this fern which has the basal leaflets very deeply lobed, which Mr. Moore calls subtripinnatum. It is a very elegant form of the fern, being more lax than the normal form, and therefore more graceful ; besides which, the deeper divisions of the larger leaflets, which procure for it the name of "rather tripinnate," make it more feathery in appearance.

\section{NEPHRODIUM, Desv.}

\section{(LASTREA.)}

Gen. Char. Sori roundish. Involure kidney- or heartshaped, attached to the frond at the indentation.

This group was formerly called Aspidium, afterwards Lastrea, and now Nephrodium, Hooker. Its distinguishing characteristic is a notch in the otherwise round involucre, which changes the simple circle into a heartor kidney-shape. Many of the largest and most elegant ferns belong to this group. Nephrodium is from a Greek word signifying kidney, in allusion to the form of the involucre.

\section{Nephrodium Thelypteris. Marsh Buckler-fern.}

Caudex long, slender, branched, creeping. Stem distant, long. Fronds oblong-lanceolate, 1 to 2 feet long, pinnate. Pinnæ horizontal, tapering. Veins forked. Sori in two rows on the leaflets. Involucres small, slightly toothed on the margin.

The literal meaning of Thelypteris is Woman-fern, and probably refers to the slender growth of the plant.

The caudex of this fern is black and slender, and it creeps as widely in its favourite marshy ground as the Oak-fern does in its shady woods; it throws out nume- 
rous fibrous roots, which soon become matted. From the various branches of the caudex arise numerous single fronds. The stems are black or purplish-brown at the base ; they are slender and brittle, and nearly as long as the leafy part of the frond. The fronds unfold in June; they are ovate-lanceolate, the pinnæ narrow and at some distance from one another, tapering at the point but broad at the base. The colour of the fronds is pale green in their youth, and a full rich green after they have attained maturity, the texture delicate and smooth; the fertile fronds are taller than the barren ones. The leaflets are oblong and rounded at the

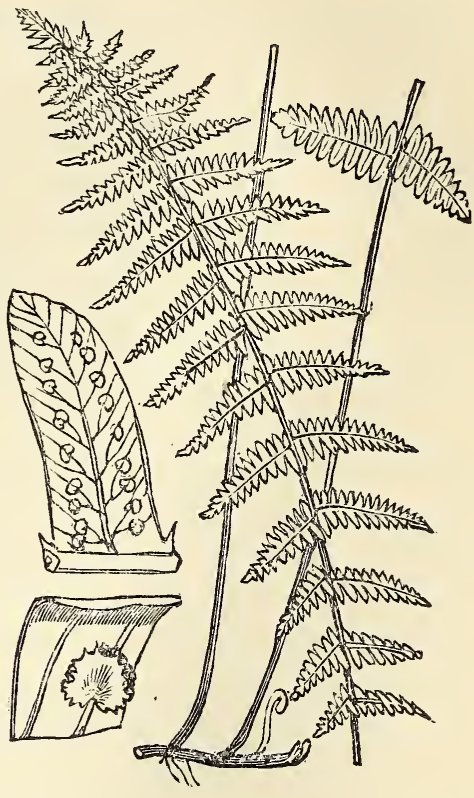
point, those of the fertile fronds look narrower, because their margin is rolled back over the sori. The pinnæ are placed opposite one another.

This is a somewhat rare fern. It frequents boggy heaths, where its branching caudex can ramble freely at its will. It is seldom found in Scotland.

Nephrodium Thelypteris grows in Asia, North America, Canada, New Zealand, and Africa.

It is a suitable fern for the foot of a rockery, where drainage, moisture, and shade can be secured. Its sine

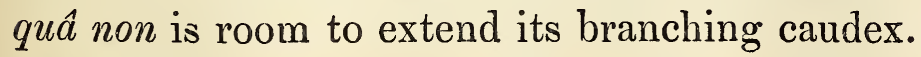

Mr. Newman separates this fern from the rest of the group, calling it Hemestheum. His reason for so doing is the creeping nature of the caudex, the characteristic 
of what he calls the true caudex; the tufted form he calls rhizome.

\section{Nephrodium Oreopteris. Mountain Buckler-fern.}

(Lastrea montana, Moore.)

Caudex short and very scaly. Stem short, tufted, scaly below. Fronds 1 to 2 feet high, firm, lanceolate, glandular, tapering above and below. Pinnæ sessile and pinnatifid. Involucre thin, slightly toothed. Veins downy. Sori on the margin.

Oreopteris signifies a fern dwelling in mountains.

The short strong caudex throws up a crown of young fronds, the stems of which are very short and densely

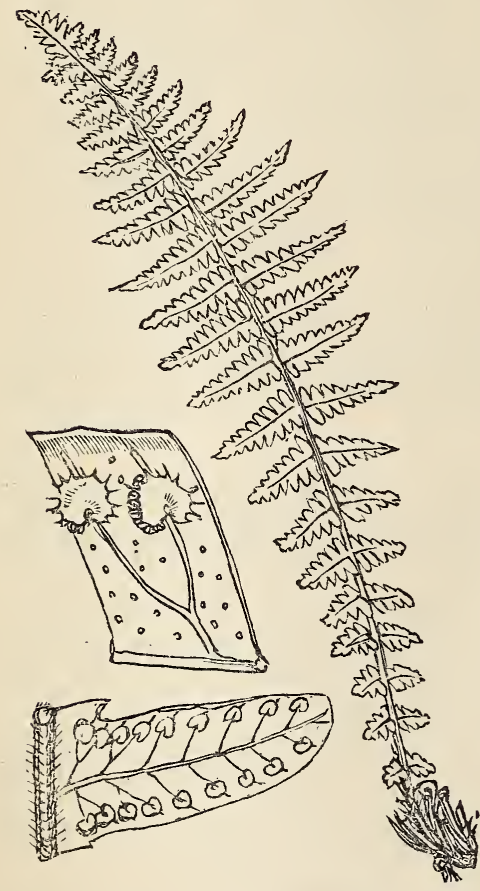
covered with chaffy scales. The form of the frond is lanceolate, broad in the centre and tapering elegantly to the summit and the base; the colour a delicate green. The fronds grow upright, and are covered underneath with shining yellowish globules, which yield an agreeable balsamic scent. The pinnæ are seated on the main stem; they are placed near together on the upper part, but are more distant below, the last two or three pairs being far apart, ever shorter and shorter and not decreasing in breadth, so that the final pair are more than half as broad as long. The leaflets are oval, entire at the edge, and bearing on the under side a beaded row of 
sori on the margin. If any doubt occurs when trying to identify this fern, you have only to pass your hand quickly over the back of the frond, and the fragrance which the glands give out will set every doubt at rest. Its bright yellowish-green hue is extremely refreshing to the eye.

There is a variety called cristatum, divided several times at the point.

Var. crispum has the leaflets waved and crisped.

Var. trincatum is less elegant than the normal form, the points of the fronds and of the pinnæ ending abruptly.

The most extraordinary variety is Mr. Lowe's Lastrea montana Nowelliana. Here the pinnæe are very narrow, and do not taper to the point at all; from their appearance they might have been broken off in the centre; they are sometimes forked. The rachis is carried beyond the end of the frond, so as to form a kind of horn, as is seen in many foreign ferns; the leaflets are very short, and the sori fully developed.

Var. furcatum has the pinnæ doubly forked.

Var. abruptum is a starved form; the pinnæ are irregular in size, and are either merely waved at the margin or slightly dentate.

Mr. Lowe also describes two varieties, interruptum and caudatum; but their differences are very slight.

The Mountain Buckler-fern frequents hilly districts, raising its crown of delicate green fronds among the grey rocks and purple ling, and hidirg the reindeer moss and cup lichens under its shade. It is often called Heath-fern, from its presence on heaths and moors. It is abundant in England and Scotland, and in the mountain regions of Ireland. 
In Europe this fern is found plentifully as far north as Norway.

It is a good variety for the fernery, only needing good drainage and shade to make it naturalize itself.

\section{Nephrodium Filix-mas. Male Buckler-fern.}

Caudex short, erect, scaly. Stem tufted, scaly. Fronds from 1 to 3 feet, broadly lanceolate, firm, bipinnate. Leaflets oblong, blunt, serrated. Sori between the mid-rein and margin, roundish kidney-shaped, smooth.

Called Filix-mas, or Male-fern, from its robust habit. The caudex is thick and black, throwing out many long black roots. The fronds spring from the crown of

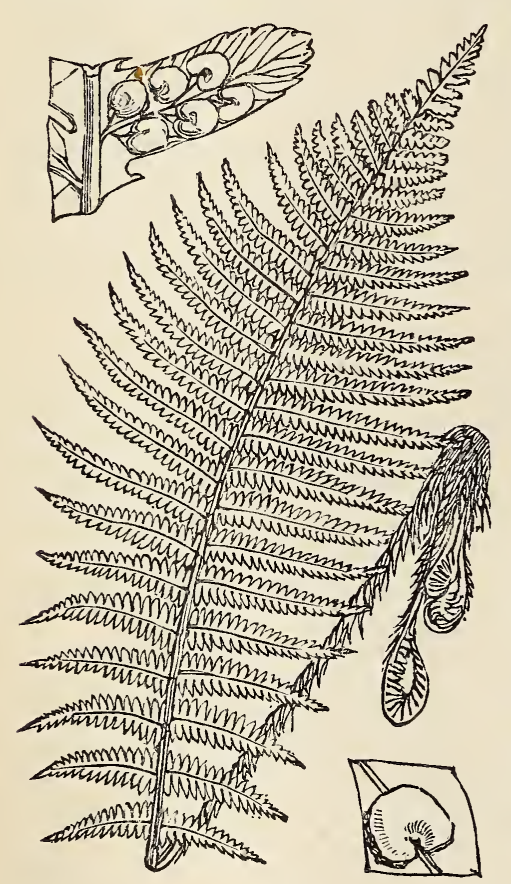
the caudex in a shuttlecock form, the stems being short, not more than one-fifth the length of the frond, and densely covered with scales. The fronds are lance-shaped, tapering to the summit, and in a less degree towards the base. The pinnæ are generally alternate, though they are sometimes opposite at the base. The leaflets are oblong, blunt, and slightly lobed. The sori are very abundant, and the involucres well developed; at first these are white, when fully grown they are lead-colour, and they turn brown before they fall off.

This is a fine stately fern, and would be much prized 
if it were rare. But being common, the inhabitant of every copse and field, it is less appreciated than it deserves to be. It was not so in olden time; in the mediæval ages this was the hero of the fern tribe. This is, or is supposed to be the fern that supplied the mystic fern-seed gathered so ceremoniously on St. John's Eve, and imparting the marvellous power to "walk invisible." The gathering of fern-seed, whether at St. John's Eve or at another period, was ever associated with witchcraft and demonology. Lyte pronounced all these fabled wonders "but trumperie and superstition," and they seem to have died out with the last century. "Vagabonds," as Mr. Newman tells us, used to make "lucky hasds," or "St. John's hands," out of the curled-in young fronds, and sell them as charms to put in the troughs from which the cattle drank.

All herbalists esteemed the Male-fern for its medicinal properties. They extracted a valuable vermifuge from its roots, and also gave it as medicine to horses.

In Norway the fronds are still used to fodder cattle, and, when decayed, for manure. When burnt, its ashes are useful in soap-making. The Siberians and Norwegians both use it as an article of food, the former fiavouring their ale with it, the latter cooking the young fronds as asparagus.

The Male-fern grows abundantly in all quarters of the globe, in all kinds of soils, and at various altitudes. Mr. Wollaston has given a large amount of patient study and investigation to this fern, and he has come to the deliberate conviction that it should be divided into three distinct species, Filix-mas, pseudo-mas, and propinqua. He gives as the distinguishing characteristics of the first, that its fronds are "lanceolate, bipinnate, par- 
tially deciduous, prostrate in winter; pinnæ of an elongated triangular form; pinnules ovate, serrate; indusium not embracing the spore-cases." The pseudo-mas he describes as "sub-evergreen, not prostrate in winter, coriaceous; fronds lanceolate; pinnæ elongated, triangular or pyramidal; pinnules paralleloid or linear, obtuse, not auricled, serratulate; indusium, when young, embracing the spore-cases, persistent, roundish, depressed." The propinquum is a subalpine form. The same writer describes it as "fronds ovate-lanceolate, bipinnate, a foot shorter than in the allied forms; pinnæ pinnate, pyramidal; pinnules crisped, strongly auricled, basal pair stipitate; indusium embracing the sporecases."

Mr. Lowe enumerates a good number of varieties of the Nephrodium Filix-mas. That known as the cristatum, or Crested Male-fern, with the pinnæ much branched at the apex, so as to form a tuft or crest at the top of the frond, is the most familiar, and is much admired in ferneries.

The var. Jervesii is also a very handsome form, of large stature, with lengthened pinnæ, and a tasselled crest. The pinnules have a crisped or curled character, and very interesting is the effect of this fern growing in its chesen habitat upon the banks of the Tees. We explored these romantic banks from the Caldron Snout, where the stream rushes through the chasm in the rocks dividing Westmoreland, Durham, and Yorkshire, to the splendid waterfall some five miles below, called the High Force, and had the pleasure of noting the crisped Filixmas with all its charming surroundings.

The var. pumilum also graced that neighbourhood, but its dwarfed fronds, with their comparatively large pin- 
nules, clustered on the high ground among grey rocks and heathery coverts, where the sward was interlaced with the twining stems of the Alpine Lycopod.

Var. Clowesii is another tasselled form, approaching Jervesii in character; it is peculiar to Worcestershire.

Var. Bollandice has broad fronds and waved leaflets, but its principal distinction is its winged rachis.

Var. abbreviatum is a dwarfed form, with crisped leaflets.

Var. angustatum is crested, and with narrow fronds.

Var. incisum is a stately form, robust, and contracting near the apex.

Var. Monkmanni is dwarfish, but of elegant form.

Var. trapeziforme is distinguished by the brilliancy of its colour, which Mr. Lowe calls "golden."

Var. recurvum is very small, and resembles some forms of Nephrodium cemulum.

Var. giganteum differs from the normal form in the opposite degree, attaining a height of 4 feet by 10 inches in breadth; it is found in Devonshire.

Var. flexuosum is characterized by the zigzag form of the rachis, and also of the secondary rachis or pinnæ stems.

Var. erosum is a dwarfed form.

Mr. Lowe describes eleven other forms: interruptum, cristatum, angustatum, productum, furcans, variabile, depauperatum, serrato-multifidum, paleaceum, imbricatum, Marsdenii, and Ruderi.

When planted in the fernery, the common Male-fern, in all its forms, grows extremely well and luxuriantly, provided space be allowed for its roots, and a large quantity of sand be mixed with its compost. It is a great recommendation to it that it can bear sunshine. 


\section{Nephrodium rigidum. Rigid Buckler-fern.}

Caudex short, stout, erect. Stems scaly, nearly as long as the leafy part of the frond. Frond from 8 to 12 inches long, oblong, pointed, erect, rigid, glandular. Pinnæ horizontal, broad, and tapering. Leaflets sessile, oblong, serrated. Veins forked. Sori in two rows. Involucres kidney-shaped, glandular, and fringed.

The fronds of the Rigid Buckler-fern rise in a tuft from the apex of the caudex, they are of a fresh green

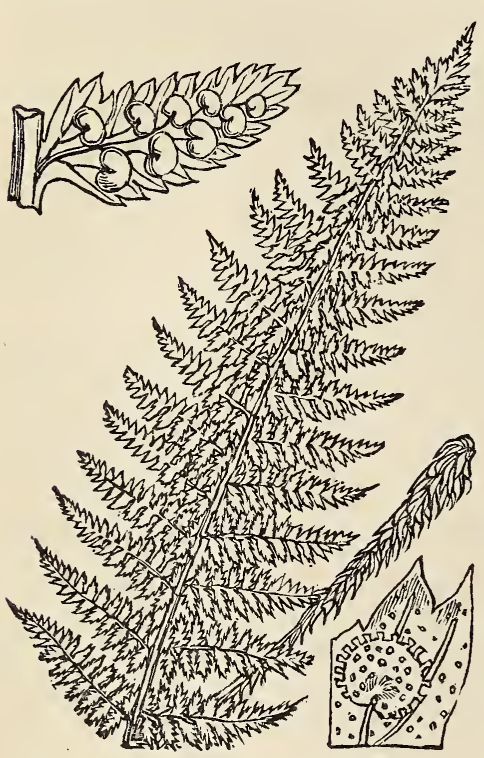
colour, and have a pleasing scent, owing to the presence of balsamic glands. The pinnæ are near together on the upper part of the frond, but more distant below. The frond always tapers to the summit, but it decreases very little below the shoulder, indeed there is one form of the Rigid Buckler-fern where the lowest pinnæ are the largest, giving a triangular form to the frond; but, as a rule, there is a slight decrease of width towards the base. The stem occupies nearly half the length of the frond. The leaflets clothing the pinnæ are narrow, oblong, and serrated. The sori are crowded, very abundant, and often becoming. confluent. They are only placed on the upper part of the frond.

This fern is found only on a limestone soil. We have seen splendid plants brought from Ingleborough, where it grows freely, nestling in deep fissures in the rocks, always at a high elevation, and sometimes so much ex- 
posed as to get sadly beaten by the winds. The mountain sheep seem well content to browse upon it. It is rare in Britain, the only authentic localities for it being Westmoreland, Lancashire, and North Yorkshire.

Its foreign homes are more abundant, extending through Asia Minor, the Morea, Sicily, and to California and the United States.

In the fernery it requires the usual attention to drainage, compost, and shade.

\section{Nephrodium cristatum. Crested Buckler- fern.}

Caudex short, stout, erect, scaly. Stem tufted, stout, chaffy. Fronds erect, oblong-lanceolate, glossy. Pinnæ stalked, oblong, tapering. Sori abundant, in two rows on the leaflets.

The caudex of the Crested Buckler-fern is thick and densely scaly, it grows in a branching manner, each branch producing a few fronds; the stem is clothed with broad scattered brown scales, it occupies nearly half the length of the frond ; the frond attains a height of from 1 to $] \frac{1}{2}$ foot, is narrow, oblong, lanceolate in form, of a yellowish-green colour, and very erect. The pinnæ are alternate, and closely placed on the upper part of the frond, distant and opposite on the lower part;

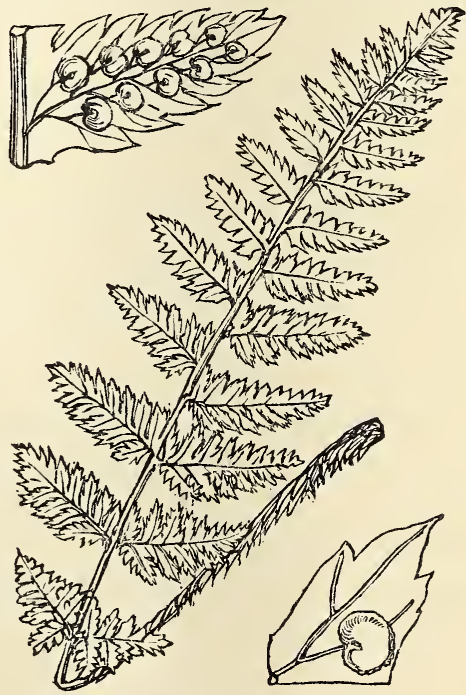
the leaflets are ovate, and sharply serrated, attached to their stem by the whole width of their base. 
There are two varieties of this fern described by $\mathrm{Mr}$. Lowe,-interruptum, with the pinnæ dwarfed and shortened as if their development had been interrupted, and furcans, where the pinnæ are more or less generally forked.

This fern is more prized for its rarity than for its elegance. Its form of unbending straightness robs the fully developed cluster of the grace so essentially characteristic of the fern family; but when we see the Crested. Buckler-fern in the growing season we have no room for dissatisfaction. The peculiar beauty of the opening fronds atones for the want of grace in the fully developed ones. While the young frond is still curled in its shepherd's-crook form, the pinnæ are not curled too, but laid together quite flat, like a child's hands at its prayers; this peculiarity gives a great prominence to the tender green outspread leaflets, which being distant one pair from another, are seen at all angles. When, therefore, you come in sight of a good quantity of the fern, a few of the fronds in each cluster having attained their full and erect stature, while others bend around them in every graceful curve, you are reminded of the charming contrast of form produced in groups of trees where the poplar towers over the luxuriant lime and drooping birch.

This is a rare fern, only favouring the boggy heaths of Cheshire, Norfolk, Suffolk, and Nottinghamshire. It is well worthy a place in the fernery, requiring but the usual care in drainage, moisture, shade, and compost.

\section{Nephrodium spinulosum. Prickly Buckler= fern. Var. bipinnatum.}

Caudex short, stout, suberect, scaly. Stem tufted, scaly. 
Fronds ovate, bi-tripinnate. Lower pinnæ distant and stalked; upper ones sessile and crowded. Involucres plain.

The name spinulosum refers to the sharp teeth or prickles on the leaflets.

The stout caudex produces a tuft of fronds from its crown, the stems of which are brown at the base and dotted with broad brown scales becoming pale at the margin. As the caudex is branched it often puts forth several coronal clusters. The pinnæ are oblong and tapering. The leaflets are toothed, each tooth ending in a prickly point. The colour of this fern is a delicate green, and the minute division of its foliage gives it a very feathery appearance, making it welcome alike in its native marsh or hedgerow, and in the artificial fernery;

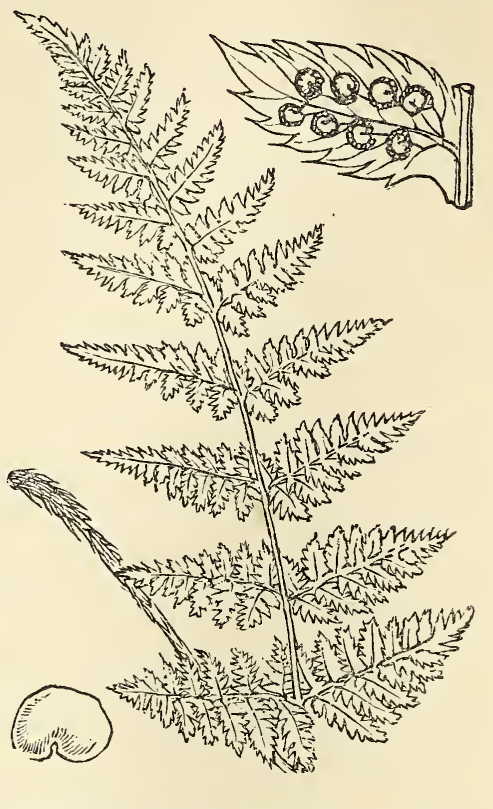
in the latter situation it requires the usual desiderata of compost, drainage, and shade.

\section{Nephrodium spinulosum. Broad Prickly Buckler-fern. Var. dilatatum.}

Caudex short, stout, suberect, scaly. Stems tufted, scaly. Fronds ovate, 1 to 3 feet high, bi-tripinnate. Lower pinnæ stalked and distant; upper, sessile and close. Leaflets sharply serrated. Sori in two rows. Involucres fringed.

Dilatatum refers to the spreading form of the frond. This fern possesses a large tufted caudex, its stems 
are brown at the base, the fronds broad and elegantly arched; the scales are broad at the base, and taper to a fine point, shading from the dark brown centre to the pale transparent edge. The lower side of the pinnæ is more developed than the upper.

Mr. Johnson fitly likens the clusters of this noble fern to Corinthian columns, the caudex and base of fronds resembling the column and the feathery outward-arching foliage the capital. Its colour is sunny green, often shading to a delicate tint at the points of the pinnæ.

This fern, though itself accounted but a variety by Sir William Hooker, has ascribed to it a perfect clan of varieties by Mr. Moore and Mr. Lowe.

Var. validum is tall, with concave pinnæ and crisped leaflets, it is a form frequently found on shady banks by rivers or standing water.

Var. interruptum has some of the pinnæ dwarfed and shorteried, as occurs in other species.

Var. pygmeum is, as its name indicates, a dwarf form ; its distinguishing characteristic is that the lowest pair of pinnules at the base of the frond are divided and all the rest are confluent; it is an unattractive plant.

Var. tanacetifolium has large triangular fronds, the foliage much divided, and the stems scaly and arched; a very handsome form.

Var. Howardii stands pre-eminent for peculiarity as tanaceiffolium for beauty. Its lower pinnæ are of normal shape and structure, but they become curiously dwarfed and distorted higher up, and are everywhere freely dotted with sori. This variety is found in the woods at Castle Howard.

The other varieties are called lepidotum, lepidum, cristatum, ramosum, glandulosum, tenerum, crispum, and Chanteria. 
Mr. Newman calls this "Withering's fern," and we envy Withering its possession, for surely no fern is calculated to call forth warmer admiration. See it bending over the waters of some gurgling brook, or still better, mirroring itself, like another Narcissus, in the still waters of a wood-girt lake, its fronds arched at every angle, the sunlight playing upon the varied green of its foliage, still sprinkled with the diamonds of the dew, and withhold admiration if you can! A lordly fern, attaining a height of from 3 to 5 feet, yet, like a true aristocrat, increasing in grace with its other growth.

Surely it is beneath the dignity of this noble fern to call it a mere variety, but we must bend to the authority of Sir William Hooker!

The Broad Prickly Buckler-fern is common. Our woods and valleys abound with it; and it frequents Germany, Sweden, Hungary, and the United States. As an object of beauty, we recommend it for the fernery, and also because it can bear sunshine, though it prefers a moist situation. It flourishes best in a rich loam.

\section{Nephrodium spinulosum. Prickly Buckler-}

\section{fern. Var. amulum.}

Caudex short, stout, suberect, scaly. Fronds ovate, 1 to 3 feet long. Involucres fringed.

\section{Lastrea fonisecii, Moore, Bab.}

Aspidium recurvum, Bro., Hook. and Arn.

REmulum means rival, in allusion to the rare beauty of the species.

This fern, though variable in size, never attains the height of the last variety. It grows from a stout cau- 
dex, in the coronal form, and reaches a height of from 1 to 3 feet. Its sori are circular and equally distributed all over the frond; they are partially covered by the slightly convex involucre, the margin of which is jagged. Its frond is triangular in form, the apex tapering very elegantly, but the most characteristic feature is the curling of the leaflets, the margins being bent forward so as to make each leaflet convex, and give the whole frond the general expression of curled parsley. The lowest pair of pinnæ are larger and longer than the rest, the under sides of them broader than the upper, as in the dilatatum. The whole frond is covered with glands. The varieties of this fern are alatum, the fronds of which are four times pinnate and very elegant, and productum, with the fronds only tripinnate.

This fern has all the arching elegance of the former, with the extra charm of the curled foliage and tapering apex. When growing in its favourite habitat under a dripping rock, in the genial woods of Cornwall or of Arran, it attains its largest size and form of drooping elegance. But when its fronds arise from the clay of Sussex and Kent they are firm and rigid, short in stature, and devoid of grace; it is then that they most resemble that glory of the culinary artist, crisped parsley. In this form it occurs plentifully about Barmouth, in Wales, adorning old walls on the Harlech road. A botanist from thence writes:- "The lovely recurva flourishes here, but in its very dwarfed, bright, crisped, and tufted form. It grows in dense clusters, the greater part of the fronds being barren, and of a peculiar bright vivid green. Every smallest part of the frond is distinctly concave. The fronds do not exceed a few inches in length. 
This fern used to be called fonisecii, or Hay-scented Buckler-fern, but Sir William Hooker prefers the term amulum.

Ireland and the West of England are its favourite habitats.

In the fernery it requires a great deal of shade and moisture. It can exist with less consideration, but if neglected it will gradually assume the stunted form.

\section{Nephrodium spinulosum. Prickly Buckler-} fern. Var. dumetorum.

Caudex short, stout, scaly. Stems tufted, scaly. Fronds ovate, 1 to 2 feet high. Pinnæ close and blunter. Leaflets broad.

This is a fern of smaller size; the fronds bipinnate and very glandular on the rachis, stipes, and lower surface of veins ; the pinnæ are blunt and concave, arranged closely together; the leaflets crowded, convex, crisp, having broad coarse teeth tipped by a sharp bristle. Altogether it is a more compact and less elegant variety; its stem is very pretty, pale green in colour, and with dark brown scales.

It is found in the mountain districts of Wales, West. moreland, Derbyshire, and the Lothians.

In the fernery it requires the same treatment as the Mountain-fern.

\section{Nephrodium remotum. Distant-leaved Buck= ler-fern.}

Caudex erect. Stems tufted, stout, a span long, chaffy. Fronds 3 to 4 feet in height, oblong-lanceolate, glossy, without glands, bipinnate. Lower pinnæ distant, stalked; upper ones 
sessile. Leaflets $\frac{1}{2}$ inch long, ovate, sessile, horizontal, rather distant, uniform. Sori abundant, heart-shaped, pale, concave, entire.

Lastrea remota, Moore.

This fern is, in its general aspect, intermediate between Filix-mas and spinulosum, resembling the former in its fructification, and the latter in the divisions of its fronds.

Mr. Clowes writes that he has cultivated this fern for several years. It was found at Windermere, about 1853, growing along with Filix-mas, spinulosum, and dilatatum, about five miles from rocks where rigidum is abundant. After growing it a year or two, he found that the caudex was not creeping, as in spinulosum; but erect, and every year the plant became more and more like Filix-mas. In the growth of the caudex it resembles Filix-mas; but the loops that its young fronds make in their early development resemble spinulosum, as does also the form of its leaflets; its pinnæ are intermediate between the two, and it has scales, some lanceolate, like those of Filix-mas, some broad, like those of spinulosum, they are very numerous and closely cover the stem, which resembles the stalk-stem of rigidum.

In the fernery it requires the same treatment as the Mountain-fern.

\section{CYSTOPTERIS.}

Gen. Char. Sori globular. Involucre ovate, inflated, springing from beneath the sorus.

23. Cystopteris fragilis, Bernh. Brittle Bladder= fern.

Caudex creeping, scaly. Stem slender, scaly at the base. 
Fronds lanceolate, bipinnate. Pinnæ triangular. Leaflets ovate, toothed.

Cystopteris is derived from two Greek words, kystos, bladder, and pteris, fern, and refers to the form of the involucre.

The common form of this elegant little fern has an elongated caudex, which throws out a number of fibrous roots, and from which plentiful clusters of fronds ascend. The numerous stems are brittle, dark red shading to black, shiny, and slender; they occupy about a third of the length of the frond, and are scaly at the base. The fronds are lanceolate in form, of delicate herbaceous texture, and attain a height varying from 6 inches to 1 foot. The pinnæ have the form of a long triangle; they are divided to

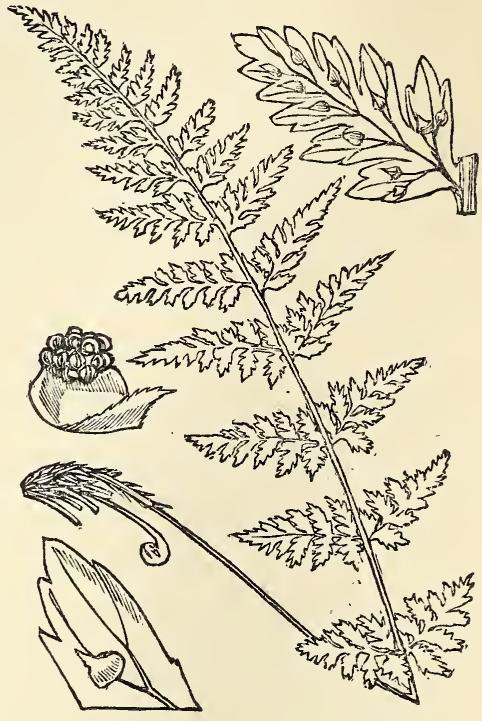
the stem, so as to be beset with pinnules, which are cut into more or less distinct leaflets. The delicate texture of the leaflets affords a good opportunity of noticing the venation; the mid-vein is waved and branched two or more times, and the sori are situated on the lower side branches. The sori are numerous, presently throwing back the hood-like involucres and becoming confluent, so as to cover the back of the frond with dark brown powder.

This delicately-beautiful fern is a pleasant object in hilly districts, projecting its feathery tufts of fronds from rocky precipices and from beneath stranded boulder- 
stones, as well as from among the decaying mortar of old towers and bridges. In the rocky dales of the north of Yorkshire the Brittle Bladder-fern meets you at every turn, its frail leaflets quivering over the well-head, as well as from the dizzy height of the Scar, or the crumbling arch of the ruin. It is equally common in similar districts in other counties of England and Scotland, but much less frequent in Ireland.

Var. dentata. This form of C. fragilis is smaller than the one just described, less decidedly bipinnate,-_indeed, the pinnæ are only divided into pinnules on the lower parts of the most luxuriant fronds ; the leaflets are eggshaped, and their colour is pale green. This is only a variety of the preceding, and is much less frequently met with than the normal form.

Var. Dickieana. This is another form of C. fragilis, and here the fronds are broader and less pointed, the pinnæ beset with broad, ovate, lobed leaflets, overlapping one another. On the upper part of the frond the pinnæ are crowded, often overlapping each other just as the leaflets do; on the lower part they are distant and opposite. The fronds measure from 6 to 9 inches, and the stem occupies about a third of its length; the few scales at the base of the stem are very narrow. The only authentic wild habitat of this fern is Cove, near Aberdeen, where it was found by Mr. Dickie, and it is named after him:

Var. angustata. Sir W. J. Hooker considers this variety of $C$. fragilis unworthy of notice, but it is both described and figured by several high authorities. It grows taller than the simple form of fragilis; its fronds are more pointed, and the pinnæ are more tapering. The leaflets are cut into sharp teeth, and are of a bril- 
liant green, which contrasts well with the lurid tint of the stem. This fern is found pretty frequently in the Yorkshire dales and also in Wales and Scotland. Mr. Johnson states that it was first discovered in Rhætia, and was hence called Polypodium Rheticum.

All these varieties are very desirable for the fernery, suiting well with the artificial rockwork, and flourishing luxuriantly wherever the drainage is thorough and a good allowance of broken sandstone and sandy loam is mixed in its compost. The common form of C. fragilis is the freest grower when under cultivation, but the more tapering fronds of angustata form a very graceful cluster, and the verdure of Dickieana may compete with that of a plant of uncurled parsley.

The Cystopteris frayilis is found in numerous localities in Europe, Northern Asia, the two Americas, South Africa, and New Zealand.

\section{Cystopteris alpina, Desv. Alpine Bladder-fern.}

Caudex creeping or ascending, scaly. Stem tufted, slender, brittle. Fronds oblong, lanceolate, tripinnate. Stems of pinnæ winged. Sori copious, small.

This fern is of a smaller size than the last described; its pinnules are more distinctly separated, and its leaflets smaller and more finely cut. It is a dainty little plant of exquisite form and delicate hue.

Several localities have been cited as homes of this plant, but, on careful examination, Sir W. Hooker pronounces the Scotch specimens to be delicate varieties of C. fragilis; the only true specimens of $C$. alpina grew on a wall in the flat part of Essex, and must surely have been planted there. 
On the Continent, it is frequently found in the Southern Alps and Pyrenees, and the mountains of Greece, but nowhere at a less elevation than six thousand feet. Mr. Newman calls this fern Cystea regia, and accounts it a variety of fragilis.

\section{Cystopteris montana, Bernh. Mountain Bladder-fern.}

Caudex long, very slender, creeping, scaly. Stems distant, slender, scaly. Fronds 4 to 5 inches long, triangular. Pinnæ spreading, the lowest ones large. Leaflets ovate, pointed. Involucres thin, hood-shaped, serrated at the edge.

This very rare fern is as elegant as it is valuable. The caudex creeps as widely as that of the Oak-fern,

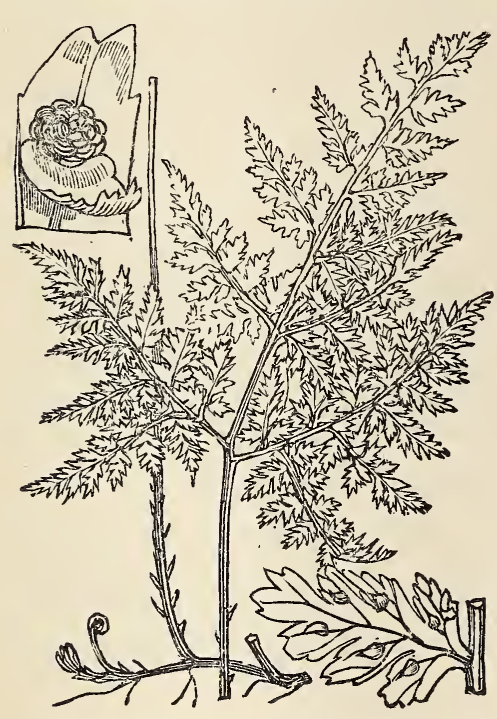
like it, throwing out fibrous branching roots, and putting up single fronds here and there. The frond is triangular in form, the lowest pair of pinnæ so nearly opposite one another and so fully developed as to give the frond a three-branched appearance, like that of the Polypody, to which it has been already compared. The stems of the pinnæ are slightly winged. The leaflets are of a delicate pale green, the veins branched, the sori situated on the side branches of the veins and covered by the hooded involucre.

The Mountain Bladder-fern is found among many of our mountain ridges, as the Breadalbane, Aberdeenshire, and Perthshire hills, and on Ben Lawers. 
Mr. Backhouse gives a most interesting account of his finding this fern among the Breadalbane mountains, in the 'Phytologist' of 1861. He met with it in profusion on Ben Lawers, occupying the moist ledges of a crag where access was very difficult. The fronds were short and destitute of sori ; they were sparely scattered over a distance of from fifty to a hundred feet. On a cliff overlooking Glen Lyon it was growing in great profusion, covering the mossy ledges for nearly a quarter of a mile, and exhibiting thousands of fronds. The largest specimens were twelve inches high, some were as much at six inches broad, and many of them were in fine fructification.

The dainty little fern was mingling with the miniature willows, Salix reticulata and herbacea, and must have looked quite important among such pigmy shrubs. The range of altitude was apparently from 300 to 400 feet.

The foreign homes are Lapland, Norway, Kamtchatka, and the Rocky Mountains.

\section{ASPLENIUM.}

Gen. Char. Sori narrow or oblong, occasionally curved, fastened to a vein, and opening along the inner side. Caudex short, erect or creeping. Veins variable, branched, and sometimes interlacing.

\section{Asplenium septentrionale, Hoffm. Forlsed. Spleenwort.}

Caudex short, thick. Roots numerous, fibrous, branching. Stems abundant, upright, tufted, two-thirds the length of the frond. Fronds tough, shiny, forked; segments erect, narrow. Sori long, narrow. 
The generic title of this family is derived from the Greek word Asplenon, a name applied by old authors to a fern then used as a remedy for diseases of the spleen. The specific name relates to the regions inhabited by the Forked Spleenwort.

The roots of this fern are long, fibrous, branching, and densely matted; the caudex very large and tufted,

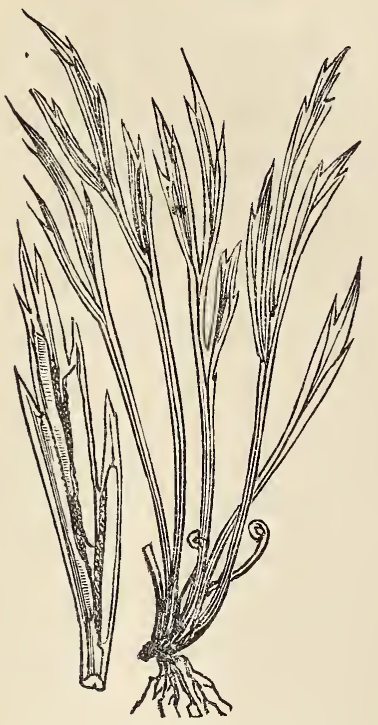
forming with the root a bulk quite disproportionate to the size of the frouds. The stems are numerous, brown at the base and green above, long in proportion to the leafy part of the frond, which is divided into forked segments; the segments are narrow or tongueshaped, pointed, and with a few sharp teeth towards the point, their colour is dull green. The whole height of the fern varies from 4 to 8 inches.

This little Spleenwort grows occasionally in great masses. We have recently found good plants of it among rocks bordering the Tweed, on the estate of Makerstoun, in Roxburghshire. The little plant might have been aware of its own value in the eyes of fernlovers, for it had selected the fissures most difficult of access as its home; and the adventurous naturalist who procured specimens of it had to cling to the face of the rock while so doing, in a manner extremely trying to witness. Mr. Newman tells us that he brought a mass of it from Llanrwst upon which were three hundred vigorous fronds, and at least as many decayed ones. 
It grows in the fissures of rocks, and in cracks in old walls in the mountainous districts of Devon, Somerset, Westmoreland, Cumberland, Wales, and Roxburghshire. It used to grow about Edinburgh, but it is no longer found, except in one unattainable situation. It is nowhere abundant.

Gerarde speaks of it as a dweller in the mining districts, and calls it Muscus corniculatus. He says, "It riseth from the ground with many bare and naked branches, dividing themselves at the top into sundry knags, like the forked hornes of a deere."

The fronds appear in March and April; in August they attain maturity, and continue green through the winter.

This fern is found widely dispersed through Europe, and also in India; it is most frequently found in Hungary, Germany, and the South of France, but even in these countries it is far from plentiful.

In cultivation it must be planted in sandy peat; it should have a very sheltered nook in the fernery, without being overshadowed by the large fronds of its com. peers; or it should be placed in a cold frame, or under a bell-glass.

\section{Asplenium Germanicum, Weiss. Alternate- leaved Spleenwort.}

Caudex short, creeping. Stems tufted. Fronds narrow, pinnate. Pinnæ oval, alternate, toothed at the point. Sori long and narrow.

Called from its prevalence in Germany.

The Alternate-leaved Spleenwort has a large supply 
of black wiry roots; the caudex is sometimes elongated, sometimes short; the stems are dark-coloured at the base,

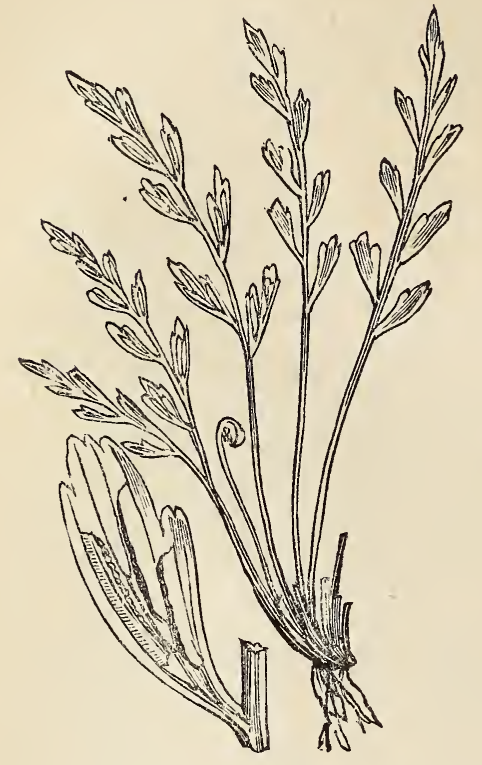

green above, about half the length of the frond; the fronds measure from 5 to 7 inches in length, they are narrow in form; the leaflets are pearshaped, alternate, the lower ones cut into lobes, the upper bluntly toothed towards the point, all of a pale green; the veins are forked, and from two to four sori are situated on each leaflet; the involucres are narrow and inflated, with a waved margin.

Mr. Newman scarcely recognizes any difference between this species and the $A$. Ruta-muraria. He erects this and the two allied species, $A$. septentrionale and $A$. Ruta-muraria, into a separate genus which he names Amerium; his reason for dividing the genus being the want of a distinct midvein in the ultimate divisions of the pinnules, and the fewness of the branching veins.

In its wild state the fronds of this fern die down in winter, but when carefully protected in the fernery or cold frame they are evergreen.

It is found in the mountains of North Wales, in Borrowdale, and in the lowlands of Scotland. Its foreign homes extend over most part of Europe, with the exception of Russia.

This fern requires great care in cultivation. It must have a poor light compost, formed of silver sand, sandy 
peat, and limy rubbish. The pot, Mr. Johnson tells us, should be half filled with the rubbish; then the earth should be put in and raised in the form of a cone, at the point of which the fern should be planted. The shelter of a bell-glass or cold frame is very desirable, but in this case care must be taken to admit the air freely from time to time.

\section{Asplenium Ruta-muraria, L. Wall Rue.}

Caudex short. Roots abundant. Stems thickly tufted, half the length of the frond. Fronds pinnate. Leaflets broad at the top and tapering below into a winged footstalk, often twice or thrice divided, toothed. Veins forked. Sori oblong.

The caudex affects a somewhat creeping habit, extending in the direction of the fissure of the rock, or the loosened mortar of the wall, amongst which its abundant matted roots make their home. The numerous stems are deeply tinted with dark purple or brown at the base; they attain a height of from $1 \frac{1}{2}$ to 3 inches, occupying half the length of the frond. The leaflets are few, leathery in texture, and of a dark glaucous-green colour above and a paler shade below. When

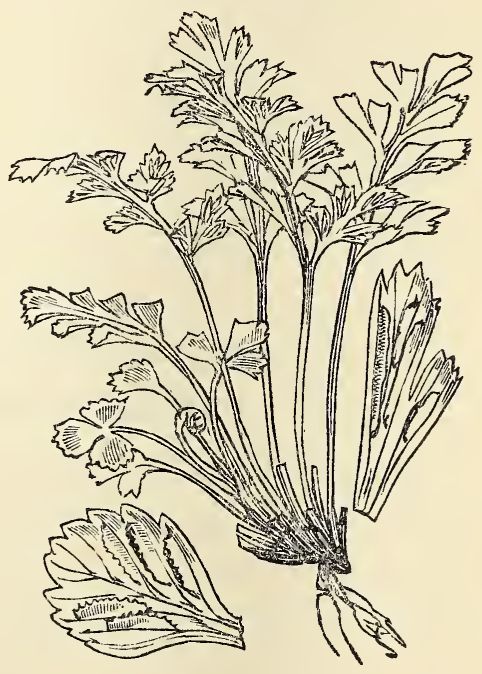
the involucres burst, the sori assume a chestnut colour, and often entirely cover the under part of the leaflets.

This fern has its own peculiar beauty, forming neat, sober-looking tufts in the churchyard wall and upon the 
bleakest rocks. Its roots penetrate so deeply that they are most difficult to extract.

- The little Wall Rue seems to have a preference for the haunts of man, especially where he builds his fences of brick. The quaint dull green tufts cluster in the walls of our old towns, establishing themselves uninvited in the most prosaic situations. But the fern has by no means forsaken its native wilds, as the limestone rocks of North Yorkshire can testify; there, and in similar districts in other counties, the Wall Rue continues to adorn the old quarry and the frowning scar, and to deck the bridges over many a brawling stream.

In olden times this fern was considered a remedy for coughs and scorbutic complaints, but all faith in its medicinal powers has died away.

It is common in Britain, and throughout Europe and temperate Asia, also in North and South Africa, North India, Thibet, and United States.

Very difficult of cultivation; the best chance of naturalizing it in the fernery is to take the plants and the stones together, and build both into the rockwork.

\section{Asplenium Trichomanes, L. Common or Maiden-hair Spleenwort.}

Caudex short, thick, fibrous. Stems numerous, tufted, coloured, glossy, only occupying a quarter the length of the frond. Fronds narrow, pinnate. Leaflets oval, blunt, dark green above, paler beneath, nearly sessile, serrated. Sori oblique, regular, oval. Involucres pale brown.

The roots of this fern are black and wiry; the caudex thick and massive, crowded with the stems of living fronds, and the remains of the stems of dead ones. The stems are deeply tinted with blackish-purple or red- 
brown; the leaflets are numerous and horizontal, they are larger, and placed nearer together in the upper part of the frond, and are smaller, and more distant in the lower part; the colour is a full, rather dull green, paler underneath ; the points of the leaflets are rounded, the base broad and straight; all the margin, except that of the base is serrated. The whole plant is pervaded by a strong woodland odour.

This fern is readily distinguished from the Green Spleenwort by its dark stem, and the full tint of the leaflets.

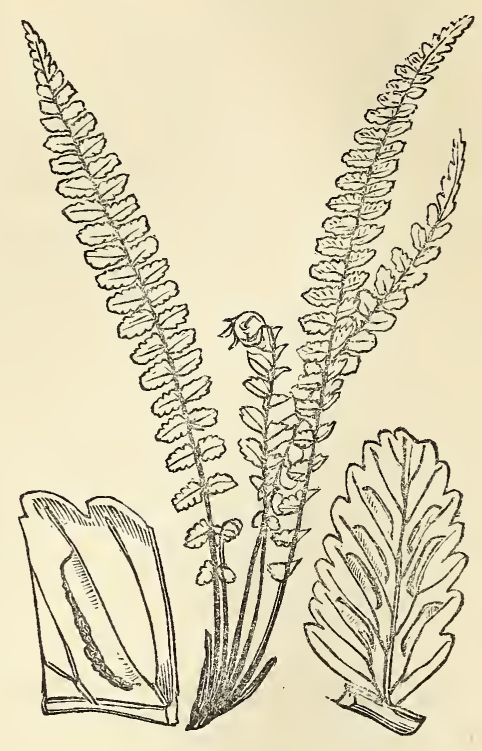

No one who has noticed ferns at all in their native habitats is unacquainted with the charm of this Maidenhair Spleenwort. A frequent denizen of rocky places, we greet its beauteous clusters with never-failing pleasure. The young plants grow in a starry form, throwing out their delicate young fronds almost horizontally, their leaflets being of a bright vernal green at that stage of growth, and the stems a ruddy purple. A little more advanced in age, dark fronds appear towering over the tender young ones, and bending in every graceful curve. When growing in rock-clefts, or on old masonry, the fronds seldom attain a stature beyond five or six inches; but see it in the rocky woodland, half-hidden under hazel or thorn brushwood, and the fronds are nearly a foot long, the caudex largely developed, and crowded with a vast number of stems, old and young. It is con- 
sidered to promote decay in old buildings by pushing its roots into the crevices.

This fern is common all over Europe, and is also found in South Africa, New South Wales, Persia, and the East Indies, North America, Mexico, New Granada, the Sandwich and the West Indian Islands.

It is easy to establish it on the fernery when once firmly planted in the usual compost, and no fern affords a more agreeable contrast, its purple stem setting off the tint of its leaflets, and its neat, compact cluster containing numerous fronds in every variety of graceful curve.

There is a beautiful variety, with larger pinnæ, deeply cut and serrated, called Asplenium Trichomanes, var. incisum. It is extremely rare.

\section{Asplenium viride, Huds. Green Spleenwort.}

Caudex short, creeping, scaly. Roots numerous, interlacing. Stems clustering, slender. Fronds narrow, pinnate. Leaflets oval, stalked, blunt, notched. Sori oblique, nearer the mid-vein than the margin, regular, at length confluent. Involucres soon perishing.

This beautiful little fern is abundantly supplied with black fibrous roots, not wiry, as in the last species, but tender; the caudex is small, blackish, and scaly, and puts up abundance of fronds. The stems are rustcoloured at the base and light green above, glossy throughout, they occupy about a quarter of the length of the frond. The fronds are narrow and pinnate; the leaflets oval, stalked, light green, and glossy; they are covered underneath with oval sori placed in an oblique direction and regular order.

The Green Spleenwort affects the horizontal style of growth more than the Maiden-hair Spleenwort. Not 
only do the young plants throw out their fronds in that manner, but in a healthy cluster you generally see a large proportion of the fronds more inclined to the horizontal than the perpendicular. It is a smaller fern than the last species, and though it frequently inhabits the same district you find it at the foot of the rocks, luxuriating in the spray of the waterfall or the moisture filtering through the loose earth, and having no ambition to mount to the precipitous rock which is all starred with

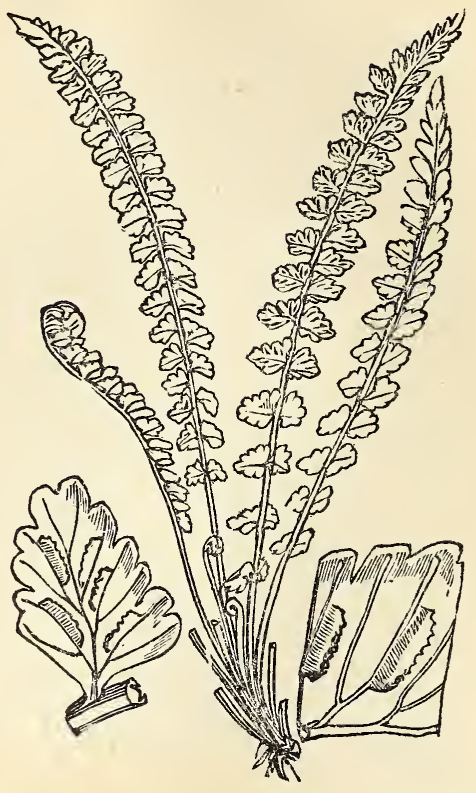
young colonies of Trichomanes. It retains its greenness through winter; its height is from 8 to 10 inches.

The Green Spleenwort is found growing freely in most rocky subalpine districts of Great Britain, where there is a sufficient supply of water for its necessities. It is equally frequent on the Continent, in North America, and the North of India.

Always a welcome inhabitant of the fernery, it is easy to accommodate there if supplied with sand and peat, and kept moist and well shaded.

\section{Asplenium marinum, Linn. Sea Spleenwort.}

Caudex short, thick, woody, crowned with long dense, purple, awl-shaped scales. Stems tufted. Fronds oblong, pinnate. Leaflets oblong, blunt, broad at the base, lobed or serrated. Veins forked. Sori large, oblique.

The roots of this fern are black and wiry, penetrating 
far into the fissures of the rock; the caudex is black,

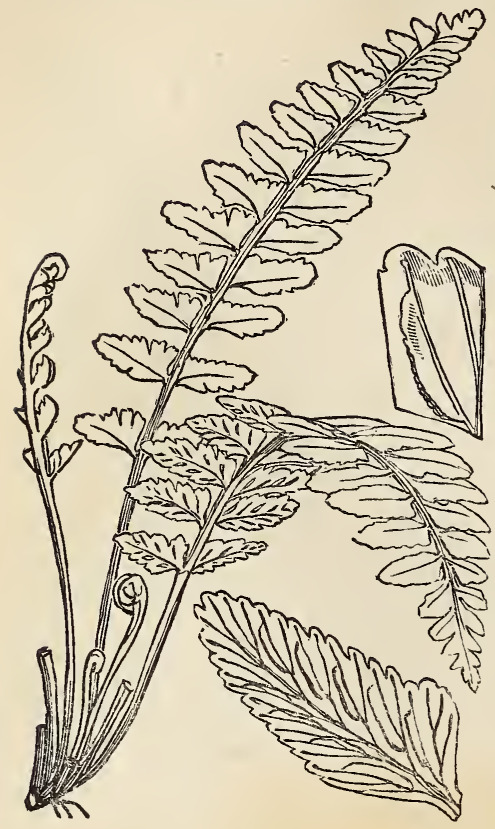
tufted, and scaly; the stems are dark brown at the base and green above, occupying from one-fourth to one-third the length of the frond; it is winged in the leafy part. The leaflets are from 1 to 2 inches long, the upper part of the base being sometimes expanded into a lobe, they are stalked and serrated, leathery in texture, and of a bright green colour. The veins are forked, and a bright rust-coloured sorus is placed on the anterior branch of the lateral vein; this is covered by a white involucre in youth. The fern is evergreen.

The Sea Spleenwort is a welcome object in its especial habitat. Clefts and caves on or near the sea beach are its favourite haunts. It grows from the side or roof of the cave, its fronds affecting an erect, bending, or pendent growth, as suits its situation, and rendered beautiful by their varying habit and verdant colour. It roots itself deeply in its rocky home, and is very difficult to take up on this account. It is a grievous pity that any should attempt to transplant it, for it is scarcely probable that it will survive the change, so essential to its welfare is the mild climate and salt-laden atmosphere of its native haunt.

The Sea Spleenwort is found on our southern and western shores from South Devonshire to the Orkneys; it is still more general on the west coast of Ireland, and 
the plants grown there attain a larger size. It is very abundant and luxuriant in the Channel Islands.

It inhabits the coast of France, Spain, the Canary Islands, Tangiers, and the western islands of the Mediterranean, Nova Scotia, New Brunswick, British North America, South Brazil, and St. Vincent's Island.

This fern is extremely difficult to cultivate. When planted in the open fernery it seldom survives many months. The only reasonable chance for preserving it in health and beauty is to place it in the shadiest corner of the greenhouse. Mr. Johnson recommends a welldrained pot filled with a compost of peat, sand, and broken brick ; the fern should be watered freely, he says, and half an ounce of common salt should be mixed with a gallon of water-this should be poured at the root, never over the fronds.

\section{Asplenium lanceolatum, Huds. Lanceolate Spleenwort.}

Caudex short, thick, woody, scaly. Stems tufted. Fronds broadly lanceolate, scaly beneath, bipinnaie. Pinnæ lanceolate, nearly sessile. Leaflets crowded, serrated. Veins forked. Sori extending nearly to the margin, large, and confluent. Involucres small, whitish.

The Lanceolate Spleenwort has long slender black roots, which penetrate the crevices of rocks and the loosened mortar of walls to a great depth; the caudex is brown, densely covered with long brown silky scales; the stems are tufted, chestnut at the base, and green above, slightly scaly. The fronds vary from 4 to 6 inches in height in a wild state, but they become much more luxuriant in a greenhouse; in vigorous plants they are erect; they appear in May, attain maturity in Au- 
gust, and last through the winter. The pinnæ are from

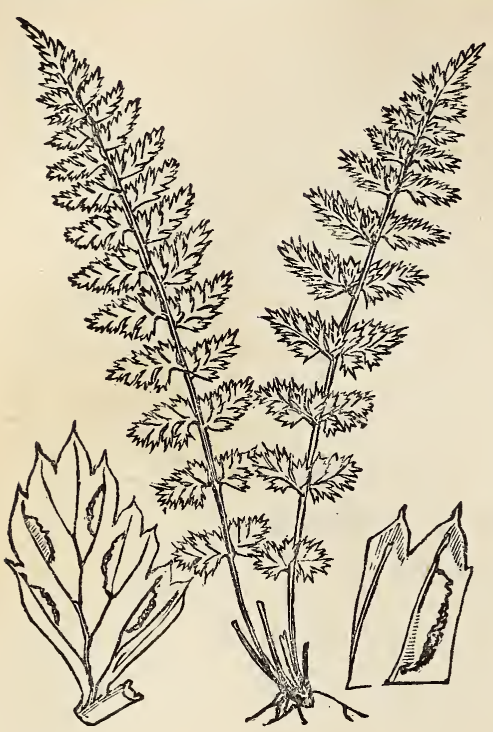

1 to 2 inches long, lanceolate; the upper ones are close together, the lower ones distant. The leaflets are bright green on the upper surface, and pale beneath. It is evergreen.

This fern grows in tufts, on rocks and in walls, wherever the climate is mild and imbued with salt from the ocean. It flourishes luxuriantly about Penzance, and in similar situations in Devonshire, Wales, Ireland, and Jersey. It flourishes most luxuriantly and abundantly in that "splendid fern-garden," Barmouth ; and it inserts itself so inextricably in the stony fissures of the rocks and between the stones in the walls, that it is impossible even for the greed of fern-collectors to exterminate it. It is easy to secure any number of fronds, but to obtain the roots is a very different matter, and one extremely hard of attainment. Here also you may find the Asplenium viride wherever water trickles from the high ground, while the Asplenium marinum adorns the shores of the estuary.

It is seldom found far inland.

The Lanceolate Spleenwort grows well in a greenhouse, it enjoys the warm atmosphere, and if provided with compost prepared as for the last species, it will become healthy and luxuriant. It can seldom bear exposure in an openair fernery, and cannot endure the close damp air of a Wardian case. 


\section{Asplenium Adiantum-nigrum, L. Black Spleenwort.}

Caudex stout, horizontal, or erect. Stems densely tufted. Fronds ovate, pointed, firm, glossy, bi-tripinnate. Pinnæ stalked, tapering. Pinnules stalked. Leaflets sessile, serrated, more or less pointed. Sori abundant, narrow, oblong. Involucres firm, pale brown.

This fern is often called Black Maiden-hair, which is the literal translation of its specific name.

The roots are fibrous and branching, when old the caudex is thickly clothed with the remains of old stems; the stems are stained of a deep blackpurple colour at the base, and the colour extends partially all its length, the stem becomes winged when it joins the pin$n æ$, it varies in length from 4 inches to 1 foot, and generally occupies about half the extent of the frond. The fronds are extremely variable in size and form, sometimes pointed-ovate, but oftener acutely triangular,

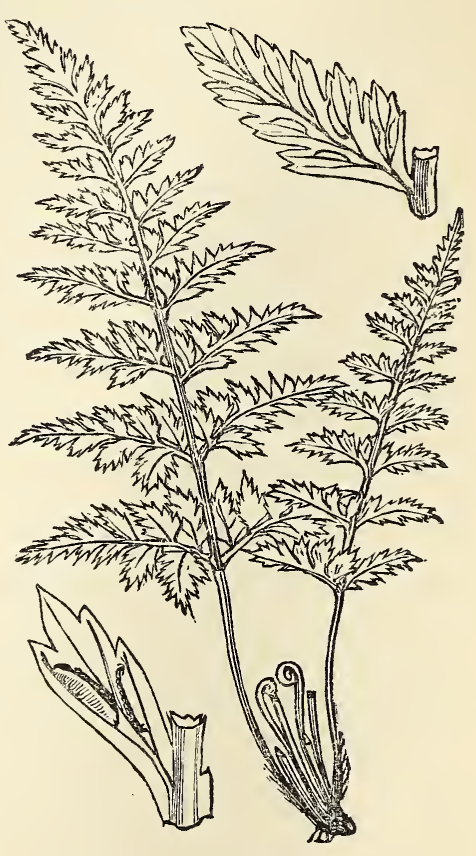
and measuring from 8 inches to half a yard in length; in texture they are leathery, very glossy, and of a bright dark-green colour; generally evergreen. The lowest pair of pinnæ are usually the longest, but sometimes the two last pairs are of the same length. The sori become confluent when mature.

This fern is so variable in form that it is often divided into several species. 
Two varieties are sufficiently marked to deserve a notice.

Var. obtusum is a dwarfed form lacking the tapering point, both in the general form of the frond and in that of each pinna; it is altogether blunter, and more compact than the typical form.

Var. acutum, on the other hand, is taller and more tapering, each pinna of greater length, less broad, and each leaflet partaking of the general drawing out to its very serratures. Obtusum prevails in dry, exposed, sterile places; acutum in sheltered shady ones.

This fern is a familiar inhabitant of rocky places and deep hedgebanks; it grows erect at first, but soon droops, and where the position favours such a growth it becomes pendulous. The fronds attain perfection in September, and last through winter. The deep hue and glossy surface of the plarit make it resemble the Ivy, and the similitude is increased by the verdure of both being in perfection when all deciduous foliage has gone to decay. In former days the Black Spleenwort was supposed to have medicinal virtues like others of its family, but these no longer obtain credit.

This fern is abundant in woodland districts, upon rocks, old walls, and at the roots of trees. In the fernery it flourishes well, giving no anxiety to the fern grower.

\section{Asplenium fontanum, Bernh. Smooth Rock Spleenwort.}

Caudex short, thick. Stem slender, tufted. Fronds narrow. or broad-lanceolate, tapering above and below, bipinnate. Pinnæ long, sessile, ovate, blunt. Leaflets ovate, minute, 
toothed, except at the base. Sori few, confluent. Involucres small, white, thin.

This rare and exquisite fern is furnished with a dense mass of roots; the caudex is somewhat tuberous; the stems slender, tinged with brown at the base, and having a few scales; the fronds are rigid, upright, from 6 to 8 inches in height; the pinnæ are near together on the upper part of the frond, more distant below; the lower pinnæ are $d$ warfed, and only divided into three leaflets.

The British habitats of this plant are said to be in Surrey, Derbyshire, Dorsetshire, Hants, and Wales, but not one

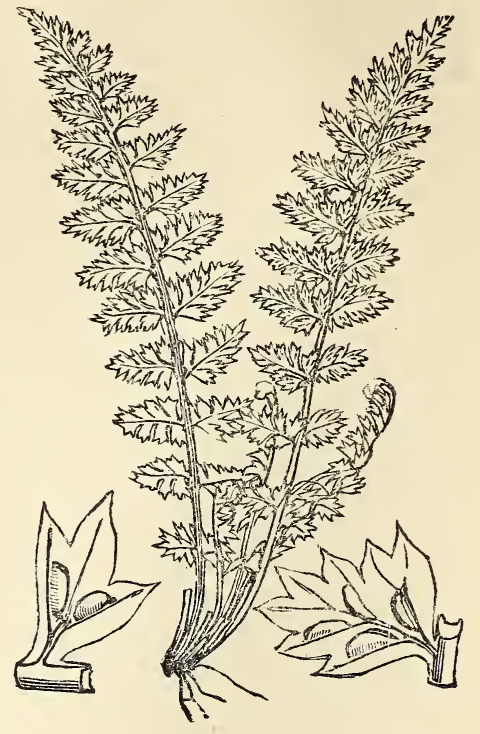
of them is well authenticated.

The best mode of cultivation for it is to place it in a pot in compost of peat, silver sand, and broken bricks.

Its foreign homes are in central Europe, as France, Italy, Spain, and Germany.

\section{Asplenium Filix-fcemina, Bernh. Short-fruited Spleenwort, or Lady-fern.}

Caudex ascending, chaffy with broad rusty scales. Stems tufted, a span long, straw-coloured. Fronds tall, oblong, suddenly tapering, bipinnate. Pinnæ numerous, oblong, lanceolate, pointed. Leaflets numerous, near together, sessile, oblong, blunt. Segments ovate, serrated. Sori copious, straight or curved. Involucres convex, fringed at the margin.

This fern is called Athyrium by Moore, and Aspidium 
by Smith, but as its involucre is attached to the side of the vein, its right place is among the Aspleniums.

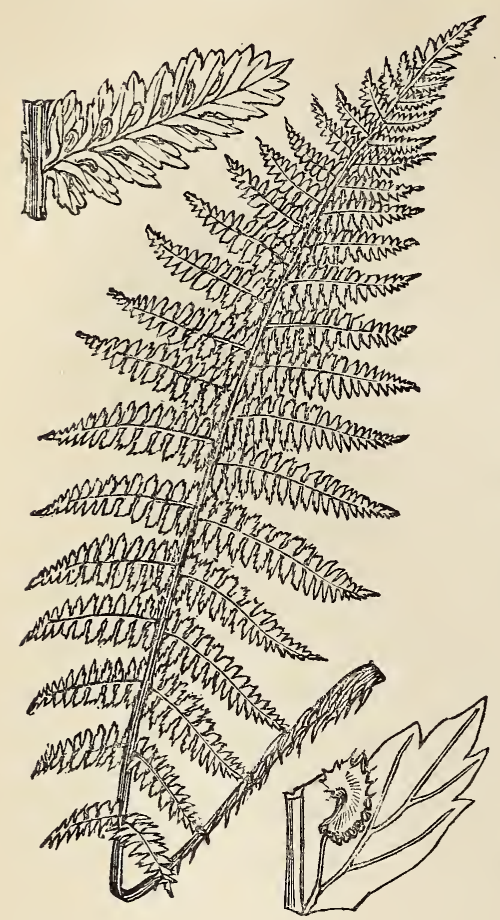

The caudex is large and protruding, Mr. Moore compares it to a rude pedestal; in this respect it shows an affinity with the tree-ferns of the tropics. The stems are numerous, and about a span long in the naked part; the fronds vary from $1 \frac{1}{2}$ to 3 feet in height, they are broadly lanceolate in form, herbaceous, and very delicate in texture, and of a light tender green. The pinnæ are from 4 to 6 inches long, the leaflets from $\frac{1}{2}$ to $\frac{3}{4}$ of an inch.

For grace of habit, elegance of cutting, and delicacy of colour, the Lady-fern stands pre-eminerit. The fronds rise in May, curled round like those of the Male-fern; in June they expand fully, and the plant assumes its form of feathery gracefulness. Blackish scales beset the stem, and the leaflets are extremely fragile.

This fern grows abundantly in moist woods, flourishing very luxuriantly in such situations. It does not shrink from exposed or dry localities, but in such its growth is stunted. In Ireland it is most abundant, and is there used for packing fish.

The Lady-fern is subject to numerous variations, eighteen different forms being noticed in Moore's 'British Ferns Nature-printed.' 
The most remarkable varieties are three which are much valued in ferneries.

Var. multifidum has the ends of the pinnæ divided again and again, which gives it a crested appearance, like that of Filix-mas cristatum.

Var. crispum is a dwarfed plant, curled and puckered in every part, so as to resemble curled parsley more than any other fern.

Var. incisum, where the pinnules are very deeply cut, so as to give a feathery appearance to the fronds.

Var. convexum is so distinct as often to be regarded as a separate species. It is more elegant in all its proportions; its leaflets smaller and more slender, and the veining is more compound in the larger leaflets.

Var. latifolium, a broad, stronger-growing variety; pinnules larger and more crowded, irregularly lobed.

Var. molle is erect, with dwarfed fronds, tapering much to the apex and to the base, its leaflets are connected by a wing to the secondary rachis.

Var. marinum, fronds small lanceolate, very elegantly tapering above and below, spreading horizontally, the sori very short, and much curved; leaflets oblong and bluntly toothed.

In ferneries all these varieties flourish well, provided room is allowed for their roots to spread.

\section{Asplenium Ceterach, L. Scaly Spleenwort.}

Caudex short, thick. Fronds tufted, lanceolate, pinnate, smooth above, densely scaly below. Scales tawny, tapering, overlapping each other. Leaflets broad, ovate, horizontal, blunt. Veins branching, and uniting before they reach the margin. Sori short, oblong. Involucre very narrow, sometimes obsolete. 
The Scaly Spleenwort has short but densely matted roots; the caudex is brown and scaly, the stems are

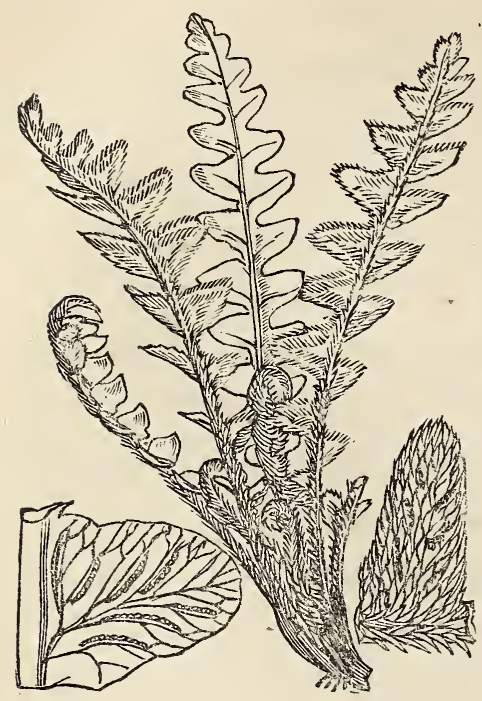
very short, and, like the caudex, densely scaly; the leaflets are thick and fleshy, of a dull glaucous-green above, and covered with a matting of brown scales below. The young fronds appear in May, the scales are then whitish, and the fronds being rolled inwards, the young curls appear as if wrapped in white flannel. The seed ripens in August, but the sori are so imbedded among the scales that it is difficult to examine them satisfactorily. The involucre is small, and being occasionally absent, and very generally confused with the substance of the scales, the claim of this species to a place in the Asplenium family has long been disputed. This is the only British species where the veins interlace, but the lateral adhesion of the sori to the vein-branch proves its affinity.

This is a pretty and distinct little fern, impossible to confound with any other. As soon as its pale coils have begun to unfold the scales turn brown, and the fronds gradually assume a more or less horizontal position. Both the flat-growing young plants and the more upright and luxuriant mature ones, form pleasing ornaments to the rugged wall or rock where nature has fixed their home. Many a rough wall in Somersetshire and Devonshire is turned into a verdant garden by the plentiful growth of this and the sister species, the Wall Rue and Black Maiden-hair. 
It frequents limestone districts in mild climates, as the south-west of England and Ireland. It is rare in Scotland.

On the Continent it is found as far north as Gothland, also in India and North Africa.

For cultivation of this fern a loam mixed with brickrubbish should be used, a cold frame or very sheltered position selected, and very little water supplied.

\section{SCOLOPFNDRIUM.}

\section{Scolopendrium vulgare, Sm. Common}

\section{Hart's-tongue.}

Caudex short, stout, scaly. Stem tufted, scaly. Fronds strap-shaped, pointed, heart-shaped at the base. Sori long, narrow, placed in pairs.

The Hart's-tongue has long, stout, black roots; a tufted caudex, blackish and scaly. The stem is short, seldom occupying morethan onefifth of the length of the frond, and beset with semitransparent scales. The frond is generally of a leathery substance, and bright glossy green colour. The length of the fronds varies extremely; dwarf specimens only attain a height of from 5 to 6 inches, and are generally upright in their growth; well-grown luxuriant specimens sometimes measure

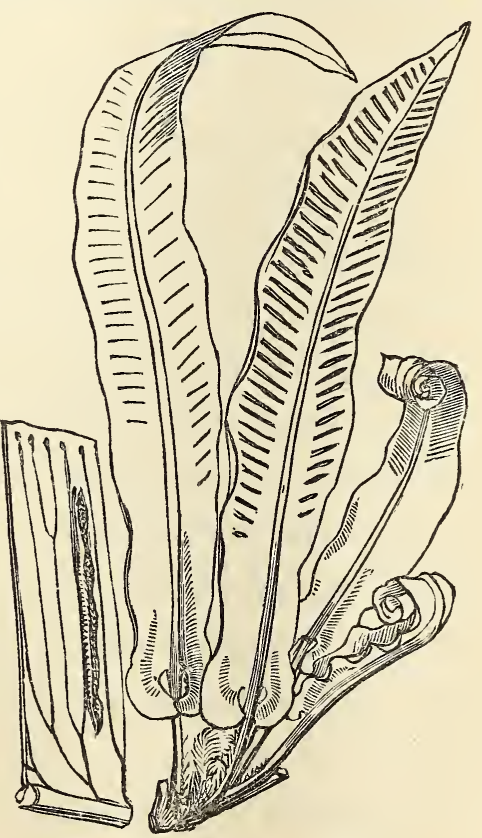
as much as half a yard, and assume every graceful form 
from erect to horizontal, arched, or pendulous. The stem continues in a strong midrib, with transverse veins, each branched twice, but the branches running in the same transverse direction. To the outermost branches of each group of veins a long narrow sorus is attached, which, meeting the sorus attached to the answering branch of the next group, the pair lie so near together that they look like one, until at last the two involucres roll back and show the two ridges of seed.

This is a remarkably handsome fern, its simple form and shining verdure making it a charming contrast to the pale feathery fronds of the Lady-fern and Shield-ferns. The young fronds appear in April, at first rolled in, then gradually assuming an erect position, from which they soon diverge into every variety of graceful arch. Seedling plants take many curious forms, being sometimes of a pointed oval figure, sometimes heart-shaped, sometimes blunt and elongated. A group of Hart's-tongue has always a charming effect in the landscape, whether its fronds droop from the grey rocks in the thickets of North Yorkshire, or from the steep red banks of shady Devonshire lanes. It also establishes itself in the crumbling walls of old ruins, in which position it is certainly not less interesting than in its native wilds.

Scolopendrium vulgare, var. crispum, has the leafy part of the frond very luxuriantly developed, so that the margin is frilled like a lady's ruffle. This variety is much valued in ferneries, where it forms a pleasing object.

Var. marginatum has narrow fronds, the margin notched into uneven lobes, which bear sori as well as the frond; it has a starved appearance, but is valued in ferneries as a rare form.

Var. multifidum has the fronds forked, often several 
times; it is found in the Yorkshire dales and elsewhere, and forms a good variety for ferneries.

Var. polyschides has very narrow fronds, occasionally becoming so deeply lobed as to be pinnatifid. It is found near Bristol.

Var. lobatum has the frond only once forked.

Var. ramosum is forked from the stem.

Var. cristatum has the points of the frond crested.

There are two varieties known in ferneries, of very peculiar appearance. One is called var. proliferum, and has very small fronds, with extremely little leafy expansions; and the other, foccundum, produces young plants on the fronds.

Var. undulatum is another form of crispum.

The Hart's-tongue grows abundantly in the British Isles, and also over Europe, in the Caucasus ; according to Hooker, it is a rare fern in the United States.

\section{PTERIS.}

\section{Pteris aquilina, Linn. Common Brake.}

Caudex long and wide-spreading. Stem erect, tawny. Fronds large, somewhat triangular, tough, tripinnate. Leaflets sessile, narrow, entire. Sori in a line on the margin. Involucre formed of the margin of the frond turned back over the sori.

Name from pteron, Greek for feather.

The roots of the Common Brake are fibrous and downy; the caudex brown, velvety, and far-spreading; the frond is bipinnate or tripinnate, in sterile soil triangular and three-branched, but lanceolate, triangular in favourable situations. The pinnæ are opposite; the leaflets ovate, elongated, sessile, and undivided, sometimes waved at the margin; the sori are situated on a 
marginal vein, which is joined by the side veins branching from the midrib.

Mr. Newman states that he received from Mr. Lees,

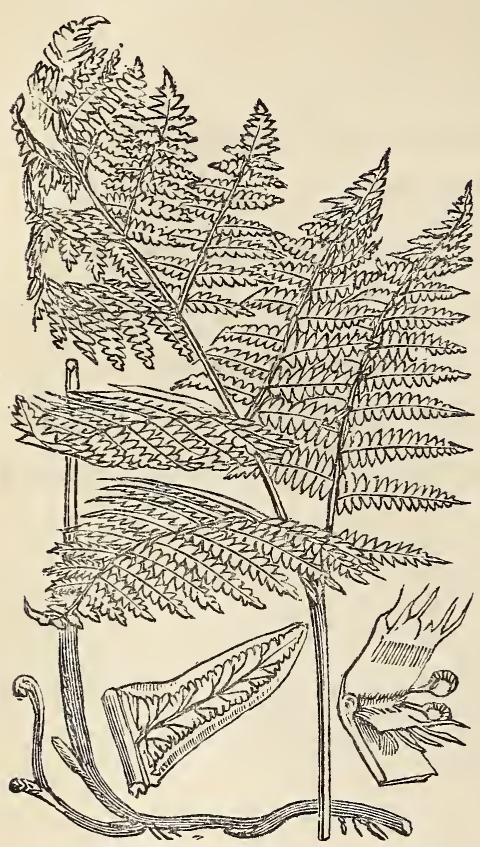
of Worcester, a specimen of a curious variety of the Common Brake. The texture of the frond was tender and delicate in the extreme; the stature was $d$ warfish, the lobes of the pinnules were flattened, and the margin broadly notched. There was no fruit upon the frond. Mr. Lees' specimen grew on a wall near Worcester cathedral, and similar ones have been found on garden walls about Deptford and elsewhere. This variety occurs generally in seedling plants, and in those grown in caves, or on stone walls or rocks. This is probably a barren state of the variety named vera.

There is another variety with the leaflets entire, called by Mr. Moore integerrima.

This is the most abundant of all our native ferns, forming a conspicuous object in our parks and woodlands, where it often attains a height beyond that of the human race, and forms a favourite covert for deer. When it grows among brushwood, it stem shoots up amid the protecting branches of the thorns, and then its feathery top expands in profuse luxuriance, furnishing light and elegant foliage to the starved shrubs. It abhors a chalky soil, and is seldom seen growing on such, 
opinion considers its presence an indication of poor land, but this is a fact certainly not proven. It is easily eradicated by the plough or hoe.

Many are the uses to which this fern may be applied. When cut green, and left to rot, it forms excellent manure for potatoes; and, used as fuel, it makes a capital fire for brewing or baking. In the Western Isles of Scotland, and also in England, the people sell its ashes to glass and soap makers; and in Wales it is burned for its alkali, which is made into balls and sold to housewives, being applied by them for washing purposes to save soap. In Scotland, Ireland, and Wales, it is used for thatching and for litter for horses. Lightfoot has recorded most of these uses to which to apply the Brake, and he adds that in many places on the Continent it is used in preparing kid and chamois leather, because of its astringency. The young shoots, when boiled, form good food for pigs; and the poor in Normandy have been reduced to mixing them with their flour. It is called aquilina because a section of the base of the stem is thought to present a likeness of the imperial eagle; while in England it is considered to represent King Charles in the oak.

Dr. Johnston stated that the mark in the section of the stem was compared to "the impression of the devil's foot;" and Mr. Newman, in repeating his statement, adds humorously, " an impression, by the way, with which I am not so familiar as to be able to decide on the aptness of the comparison."

This fern grows in all parts of the world, from Lapland to New Zealand; it is found in dense forests, by the seashore, luxuriating in the marsh and crowning mountain ranges. 
Mr. Newman calls it Eupteris ; it is the Filix-foemina of old authors.

\section{CRYPTOGRAMIMF.}

\section{Cryptogramme crispa, Br. Parsley Fern, or Rock Brake.}

Caudex short, thick, scaly. Stems numerous. Fronds of two kinds: barren ones bipinnate, fertile ones tripinnate below. Leaflets oblong, obtuse. Sori roundish or oblong. Involucres formed of the substance of the frond, turned back at the margin, spreading in age from the swelling of the sori.

The Parsley-fern, called Cryptogramme by Sir William Hooker and others, and Allosorus by many older authors,

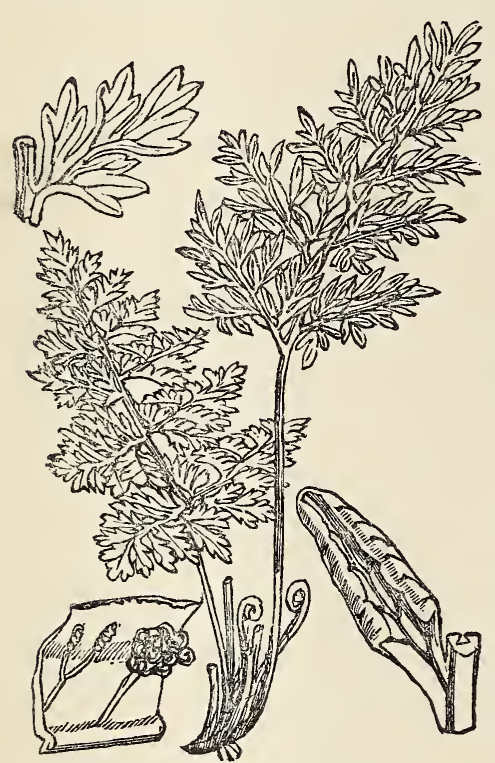

has numerous fibrous roots which adhere closely to the earth or rock-cleft ; a caudex which extends itself horizontally, though it can hardly be said to creep; and fronds of two kinds, differing in their height, the length of their stems, and the form of their leaflets. The barren frond is leafy, the stem is rather more than half the length of the frond, and the leaflets are cut into three lobes. The fruitful frond is half as tall again as the barren one, the stem is longer in proportion, and the leaflets are narrow from the margin being rolled in to form an involucre for the crowded lines of sori.

This fern is an ornamental object among the rocks 
and sub-alpine pastures in the north-west of England and Scotland. It grows like a luxuriant tuft of parsley, its triangular fronds resembling the compound leaves of that plant. It is unknown in the middle and south of England, and avoids limestone districts as carefully as the Rigid Buckler-fern selects them.

A compost of loam, peat, and brick ruhbish must be prepared for it in the greenhouse or fernery, and a welldrained situation chosen; it is shy of growing in cultivation, but where the drainage is well attended to it may be preserved for a considerable time.

The Parsley-fern is found throughout the middle and north of Europe, in Asia Minor, Northern India, North America, and British Columbia.

\section{BLECHNUM.}

4.0. Blechnum boreale, Sw. Northern Hard-fern.

Caudex thick, erect, Fronds of two kinds, numerous, narrowlanceolate. Sori long, narrow, parallel with the mid-vein. Involucres long, narrow.

Name derived from the word blechnon, Greek for fern.

The Northern Hard-fern has black wiry roots, a hairy caudex, very short stems, coloured purplish-black and polished, and narrow fronds of two kinds. The barren fronds are lanceolate in form, tapering to the apex and the base; they are pinnate; the leaflets narrow, oblong, sessile, and plain at the margin. The fertile fronds grow to a greater length, the leaflets are more distant, becoming very far apart, and so small as to be merely rudimentary as they approach the base; sori abundant, covering the entire back of the leaflet when ripe.

The growth of this fern is very peculiar. The barren 
fronds are very numerous, their stems tough but lax, they assume an almost horizontal position round the

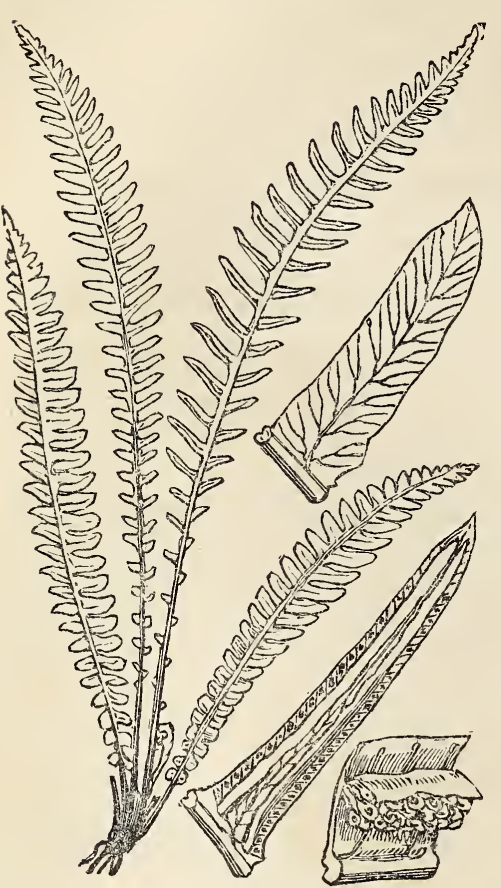
tuft, lying over one another, and hiding their pale lining while the dark green surface is fully exposed to the light. The fertile fronds rise from the centre of the plant, their stems are stiff and brittle, they attain a greater length than the barren ones, and form a strong contrast to them in their perpendicular growth; the seed is ripe in September, and after shedding it the erect fronds fade and die away.

The Hard-fern is a frequent inhabitant of heathy and stony places, where the soil is poor and light. Wherever a ditch or brooklet wends its way among the brushwood or moorland, this fern clusters on its margin, often laving its barren fronds in the water. A fragrant woodland odour lingers about its stems and caudex; it is easily cultivated in the fernery, only requiring shade and drainage.

This fern is found throughout Europe and in many parts of Asia.

\section{ADIANTUM.}

41. Adiantum Capillus-Veneris, L. Maiden-hair Fern.

Caudex scaly, creeping. Stems slender, brownish-black, polished. Fronds ovate in form, branched. Leaflets thin, deli- 
cate, fan-shaped. Sori roundish or oblong, situated on the margin. Involucres formed of a lobe of the leaf turned back.

Name from adiantos, dry, on account of a property the leaflets have of turning off the damp.

The roots of the Maiden-hair are wiry, black, and fibrous; the caudex is scaly, and somewhat creeping; the stems slender, unbranched for half the length, and then spreadinginalternate branches and hair-like footstalks; the leaflets are extremely delicate and semi-transparent in texture, yet so succulent that under strong pressure they yield three-quarters of their weight in juice; they are irregularly fan-shaped, each lobe bearing a sorus at the point, and folding back with

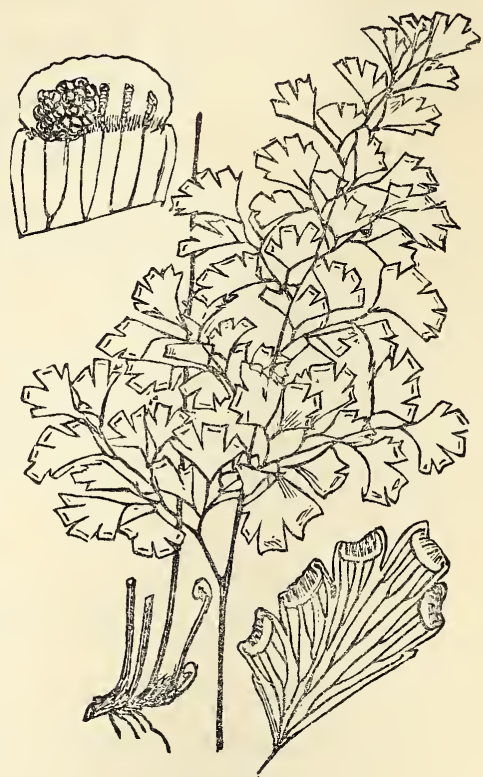
it as if for security.

This is perhaps the most elegant of all our ferns, its lightly-strung leaflets trembling in every zephyr, and render it equally desirable for the rock-work in the greenhouse, and the bouquet of the bride.

It used to be much vaunted for its many virtues, which Ray and others detail. Its juice entered largely into the liquid called capillaire, which Sir J. E. Smith tells us formed a refreshing beverage. On the Continent the Maiden-hair is still made into a wash for the head, and is considered greatly to promote the growth of the hair. 
The natural habitat of the Maiden-hair fern is in the fissures of rocks near the sea in warm climates. A few localities in the south of England, as St. Ives and Ilfracombe, and a few in Ireland and Wales, are the only British resorts of this fern; and even in such a warm atmosphere it grows shyly, generally selecting a perpendicular surface for its few elegant fronds to droop from. In the south of Europe it grows in profusion, clothing the mouth of wells, and the roofs and sides of caves.

In cultivation it is useless to attempt to grow the Maiden-hair in the open fernery; in the greenhouse it flourishes very well. Mr. Johnson directs that the pots in which it is placed should be plunged in pans of shallow water, the decayed fronds removed from time to time, and the compost formed of lime rubbish, sandy peat, and pebbles.

\section{TRICHOMANES.}

Gen. Char. "Involucre subcylindrical, entire or nearly so. Capsules sessile, with a broad, entire, oblique ring, surrounded on a columnar receptacle. Receptacle usually exserted in the form of a bristle."-Sir W. Hooker.

\section{Trichomanes radicans, $\mathrm{Sw}_{\text {, }}$ Rooting Bristle- fern.}

Caudex long, creeping, downy. Stems winged. Fronds ovate, pointed. Leaflets oblong, blunt, often in two teeth. Involucre cylindrical. Sori seated upon a centre column.

The name is formed of two words, meaning hair and excess, in reference to the bristles.

This only British Bristle-fern has numerous long thread-shaped rootlets, the caudex is slender, creeping, black, and downy, it branches and intertwines so as to 
form a curtain of net-work over the rock; the stems occupy about one-third the length of the frond, and have wings of the same substance as the leaflets. The frond is oval in form, varying to triangular, its substance resembles that of a seaweed, thin and transparent. Each pinna is furnished with many pinnules, which in their turn are divided into leaflets with three or more lobes, a mid-vein running through the leaflet sends a branch into each lobe, and one branch passes beyond the leaflet, the sori cluster round its base, and an urn-

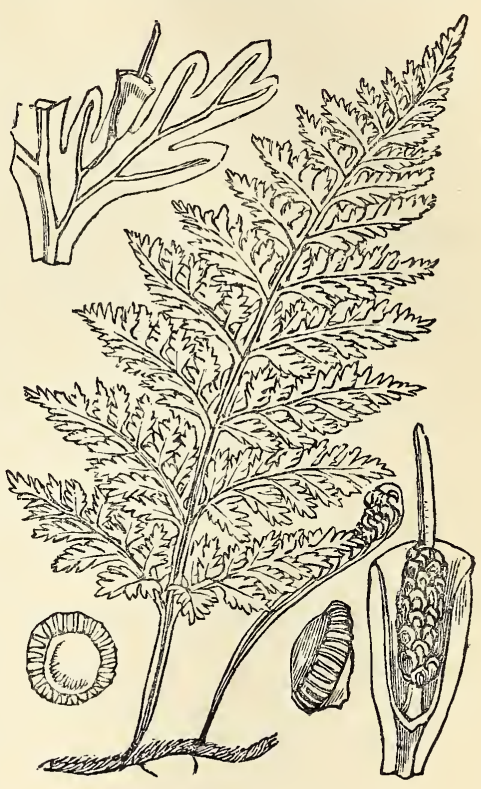
like involucre forms outside them, leaving the bristlepoint of the vein naked; this forms the distinguishing feature in the family.

To see this plant in its full beauty we must visit Ireland and gaze on the waterfalls of Wicklow, Kerry, and Killarney, where the fern grows in curtains of verdure, every frond shining with the diamonds of the spray. The delicate texture of the fern possesses a wonderful power of revivification, and may be freshened after being dry for years, by immersion in water.

It has been found in one or two places in Yorkshire, but has of late been sought there in vain. But we learn from the Botanical Staff at the British Museum that it has been found recently in Wales, and in the Isle of Arran, off the coast of Galway. It is evergreen; young fronds appear in May, but do not expand till autumn, 
and their full stature is not perfected till the second year; the third year is their harvest-time.

In order to grow this fern in the greenhouse Mr. Johnson directs that a pot be filled one-third with broken crocks and sandstone rubbish, and the remainder with equal parts of fine loam, silver-sand, and powdered sandstone; the roots then to be laid on the surface, and fixed with pegs, then a little sand strewed over, just enough to cover the roots, the whole watered liberally from a pot with a fine rose, and plunged in a saucer full of water, a bell glass being turned over, its rim resting in the saucer.

This fern is abundant in the south of Europe, and in various parts of Asia, North and South America, the West Indian and Sandwich Islands.

\section{HYMENOPHYLLUM.}

Gen. Char. Involucre two-valved. Sori sessile, with a broad ring.

\section{Hymenophyllum Tunbridgense. Tunbridge Filmy-fern.}

Caudex thread-like, creeping. Stems winged. Fronds tender, pinnate. Leaflets narrow, toothed. Involucre urn-shaped and sharply toothed.

The Filmy-ferns are moss-like plants; the name is derived from two Greek words-hymen, membrane, and phyllon, leaf.

The Tunbridge Filmy-fern has slender thread-shaped roots proceeding alone, or in twos or threes, from a brown caudex, nearly as slender as themselves. The fronds are formed of branching veins, winged with ver- 
dant membrane, and quite transparent. The pinnæ are alternate, divided into frorn two to seven leaflets; at the base of the higher pinnæ on the upper side a vein passes beyond the membranous wing, and bears upon its summit a cluster of seed-masses, each encompassed by a ring, this fruitful vein is in its turn enveloped in a membranous involucre, which is composed of two valves, open and sharply toothed at the upper end.

This fern grows in extensive plots upon the surface of damp

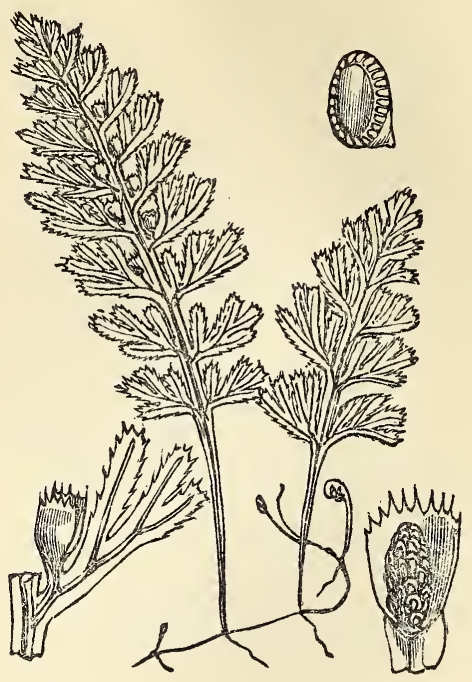
rocks, its caudex closely interlacing and soon hidden by a thick forest of tiny, transparent, moss-like fronds. It is found in Wales and Scotland, also in Cornwall, Devon, and at Tunbridge Wells. Sir William Hooker states that it is found both in the New and Old World.

The most suitable mode of cultivation for the Tunbridge-fern is to place it in a Wardian case; the next best plan is to treat it as Mr. Johnson recommends to be done to the Bristle-fern.

\section{Fymenophyllum Wilsoni, Hook. Mr.Wilson's Filmy-fern.}

Caudex creeping, thread-like. Stems slightly winged. Fronds rigid, transparent, pinnate. Pinnæ generally turned to one side. Involucre entire, upright.

Mr. Wilson's Filmy-fern closely resembles the Tunbridge species, but the entire margin of the involucre at 
once distinguishes it from its fellow, and to the general

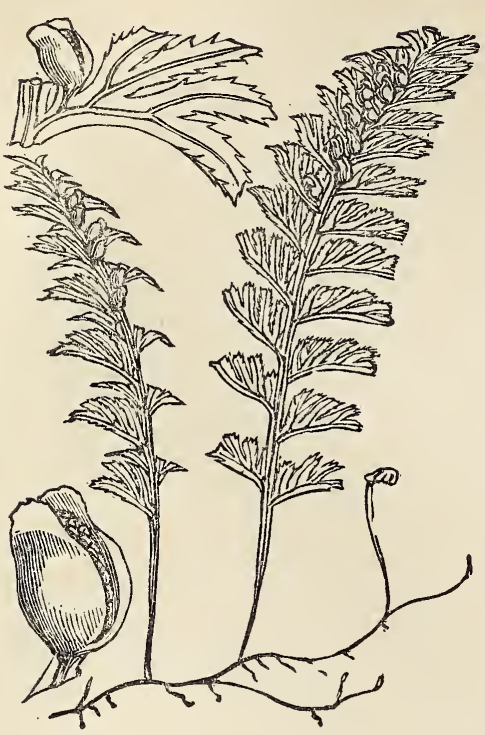
observer the mode of growth of the fronds, turning the pinnæ to one side, and bending in an arched direction, forms a good feature for identification. In habit of growth, situation, texture, and general appearance, the two are closely allied, but the one just described generally attains a somewhat larger size and grows more freely; they require exactly the same treatment under cultivation.

\section{OSMUNDA.}

Gen. Char. "Capsules subglobose, coriaceous, pedicellate or sessile, reticulated, opening vertically halfway down into two valves, and having on one side towards the apex a very small, incomplete, gibbous ring. Involucre none."-Sir W. Hooker.

\section{Osmunda regalis. Osmund Royal, or}

\section{Flowering-fern.}

Caudex very large, ascending; stems tufted, smooth, fronds bipinnate, oval; leaflets oblong, entire, sometimes lobed near the base, panicle of fruit at the summit of the frond.

Name derived from two Saxon words, os, house, and mund, peace; or else commemorative of the story of Osmund the waterman.

The flowering-fern has strong fibrous roots; the caudex is very large, and when protected by bushes, and favoured by marshy ground, it often rises as much as a 
foot from the soil, quite in the style of the tree-ferns. The fronds are narrow in proportion to their length, and generally erect; they are pin-. nate, and crowded with a cluster or panicle of sori, they attain a height of from 3 to 7 feet. The pinnæ are furnished with a double row of leaflets, placed opposite to one another, elongated, blunt, and plain at the margin, except when a lobe or ear is formed near the base ; the texture of the leaflets is leathery, the colour glaucous. The capsules or sori open vertically into two valves, are firm in texture, green in youth, and chestnut in maturity.
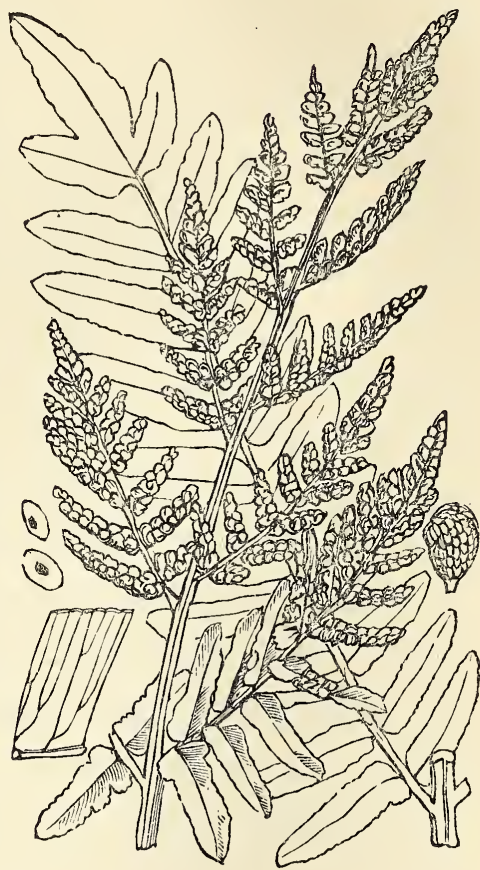

This fern is perhaps the most lordly of our native species, and is justly named Royal Fern. Its noble fronds rise in luxuriant clusters, more or less erect in general, but drooping when they are situated beside water, as on the shores of the Lakes of Killarney, where Mr. Newman describes them as quite pendulous. The flowering-fern ever chooses the most romantic situations as its home, now lifting its head from the marshy ground where the old Jewish town of Marazion once flourished, and now waving its leafy fronds amid the rich woods bordering Loch Lomond or Loch Katrine. The fronds appear in May, their stems often tinted with rose-colour in their early youth; they attain maturity in August, and die down in the first severe frost. 
The royal infants of this princely fern are as beautiful and characteristic as any young nobility can be. The seedling puts up single ivy-shaped fronds upon a long stem, and no one would guess that the clusters of longstalked ivy-like leaves could bear any relation to the pinnate branches of the almost arborescent fern which tower over them. The striking contrast may be seen in the herbarium at the British Museum, where the infant seedling reposes beside the fully developed fruit-bearing form of the mature plant.

The legend which, according to some authors, gave the name of Osmunda to this fern, is of some interest.

A waterman called Osmund dwelt on the banks of Loch Tyne, along with his wife and young danghter, who was fair as blue eyes and flaxen locks could make her, and withal graceful and fleet of foot as a young deer. The good man was plying his boat on the Loch, and the girl and her mother sat on the bank watching the dip of the oars and the reflections in the water, when a noise as of the approach of armed men was heard, and the poor waterman rowed hastily to the shore, filled with the dread inspired by every threatening of the ruthless Danes. With all speed he hurried his wife and child into the boat, and pulled lustily for the nearest island, where he bade them lie down among the tall floweringfern. They had just entered the covert when the Danes appeared on the shore, and authoritatively beckoned Osmund. He obeyed their behest, and they bade him put their troops across the Loch. Right eagerly he laboured at the oars, carrying one boatful after another past the island where his loved ones lay concealed, and right joyously did his heart beat as he put the last group on the opposite shore. They wend their way in peace, 
having no thought of any possible prize left behind, and as they disappear from his sight the waterman kneels to thank God for this wonderful salvation.

Gerarde calls this fern Osmund the Waterman, and Sir William Hooker suggests that St. Osmund, who came over with William the Conqueror, and afterwards became Bishop of Salisbury and Chancellor of England, may have been a patron saint of watermen and waterplants, as St. Christopher was, after whom this same plant was called "St. Christopher's Herb" in past ages.

This fern flourishes well in cultivation if a damp situation on the margin of a pond can be secured. To form an artificial habitat, Mr. W. Reeve prescribes a compost of three parts fibry peat, one part vegetable mould, and one part silver-sand, and an abundant supply of water.

The group of ferns of which this Royal Osmund may be accounted a head, is characterized by the seed being contained in firm capsules, and situated on a simple or compound spike, distinct from the leafy part of the frond.

The flowering-fern is found in most parts of Europe, in North America, Canada, the Cape, Mauritius, Madagascar, China, and Japan.

\section{OPHIOGLOSSUM.}

Gen. Char. "Capsules fleshy, 1-celled, 2-valved, opening transversely, connate, forming a compact 2-ranked spike. Involucre none." - Sir W. Hooker.

\section{Ophioglossum vulgatum, Linn. Common Adder's-tongue.}

Caudex small, deeply rooting; frond simple, ovate; capsules on a spike; spike simple stalked. 
The name is derived from ophis, serpent, and glossa, tongue.

The Adder's-tongue has a small carrot-shaped root,

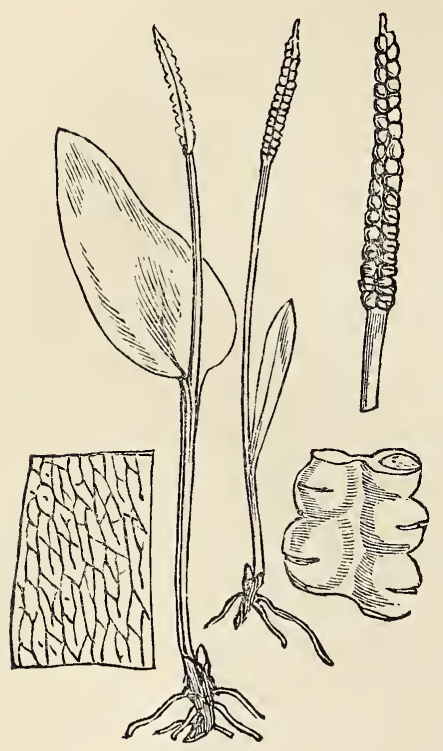
with long fibrous rootlets diverging from it horizontally. The caudex rises in an erect position, it is protected by a brown sheath at the base, and the plant for next year appears as a bud also enveloped in a brown sheath, the fac-simile of the sheath protecting the base of the present caudex. The frond is leathery in texture, oval egg-shaped or narrow, very smooth, and of a pale green colour; a stalk arises from the centre of its base, and bears a spike at the summit, the spike consisting of two rows of capsules which, when mature, split horizontally and release the spores.

This fern grows in meadows and pastures, and is often difficult to find from the fact the growth of the herbage keeps pace with, or exceeds, the growth of the frond. It is abundant in the localities which it affects, and these may be more numerous than we suppose, because of the concealments which surround it. It is still much esteemed for its curative powers by old wives and dealers in simples. The first time we found the plant, we were guided to the meadows it favoured by a wise woman, who was accustomed to make ointment from its fronds. In Turner's time it was greatly respected; he says, "This is a wounde herbe, and healeth woundes that are almost incurable, or at least wonderfully hard to be 
healed. The nature of it is to dryve away great swellings, and to prevent extreme inflammation."

This fern is extremely difficult to keep alive in the fernery; it can only be transplanted safely by taking a large sod with it, of a depth greater than that reached by the roots, and it is not ornamental enough to make it worth while to be at great pains.

The Adder's-tongue is found in temperate climates all over the world.

\section{Ophioglossum vulgatum, L., var. angustifolium. INarrow-leaved. Adder's-tongue.}

This permanent variety of the common Adder's-tongue is peculiar to Jersey, and is described by Mr. Moore as O. Lusitanicum. Sir William Hooker is less satisfied of the permanence of its differences than other authors seem to be, having specimens of the common Adder'stongue from Orkney verging very near to the narrowleaved variety.

In the Jersey specimens the frond is narrow, and there is frequently a second frond springing from the root, without any spike annexed.

\section{BOTRYCHIUM.}

Gen. Char. "Capsules subglobose, sessile, clustered at the margin and on the side of a pinnated rachis, 1-celled, compressed, opening transversely. Involucre none."-Sir W. Hooker.

\section{Botrychium Lunaria, Sw. Common Moonwort.}

Caudex one with the stem; frond oblong, pinnate, leaflets crescent-shaped, toothed; spike compound, capsules sessile, clustered. 
The Common Moonwort is furnished with stout succulent roots; as in the Adder's-tongue the caudex

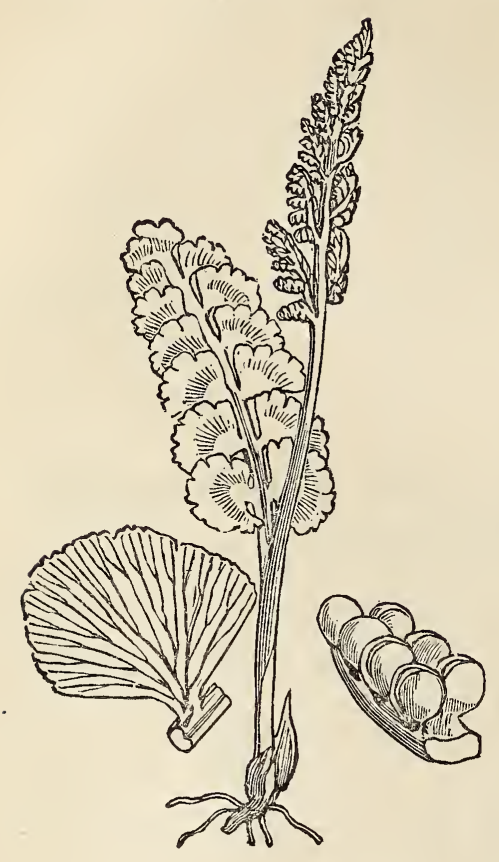
and stem are one, and the base is enveloped in a brown sheath. In the centre of the swollen base another sheath is contained, and within it the young plant for next year, perfect in every part; within the base of this is a still more minute embryo, that of the second year's plant! The stem shoots up an inch or two above the ground, and then the frond diverges obliquely from it, its two rows of crescent-shaped leaflets tinged with a purplishgreen horse-shoe mark in the centre. The leaflets are of a full green, leathery in texture, and placed opposite one another. The stem, continuing upwards in a perpendicular direction, is crowned by the compound spike, greenish in youth, pale chestnut in maturity, the capsules all turned one way.

Mr. Cruikshanks found a curious variety of this fern growing on the sands of Barry, near Dundee. It had large roots without branches, and very succulent. The stem was branched near the summit, the barren branch was pinnate and triangular, the pinnæ long and narrow pinnatifid, the leaflets cut into two or three lobes. The whole of the barren branch resembled a leaf of Thalictrum, hence the plant was called Rue-leaved, Botrychium rutaceum. Sir William Hooker does not include this among his species, so it has either not been found 
in Britain recently, or the characteristics have not been found permanent.

Gerarde celebrates the praises of the Moonwort. "It is good to heal fresh and green wounds," he says. But it is more famous as a herb of superstition than as one of healing. The author above quoted declares that witches used to loose locks by inserting it in the keyholes, and let horses loose at night with it. Coles also speaks of its pick-lock powers, and adds that the shoes of horses fall off when they step upon it.

It grows in much the same localities as those frequented by the Adder's-tongue, that is, in pastures and meadows; like it, it is very difficult of cultivation, and must be moved with a heavy sod. Mr. Johnson says it will flourish in a light soil mixed with a little peat, and must have its roots covered with turf, but will by no means endure its fronds being overshadowed.

This fern is found in cool regions throughout Europe Northern India, and North America.

\section{LYCOPODIACE $\mathbb{E}$.}

\section{IYCOPODIUII.}

Gen. Char. "Capsules without a ring, coriaceous, sessile in the axils of the leaves, or in distinct bracts, 1-celled, 2-3-valved. Stems leafy, terrestrial. Vernation not circinate."-Sir W.J. Hooker.

The family of the Lycopods are allied to the ferns more closely than to any other group of plants. They have spiral vessels in their stems, mingling with the cellular structure; their leaves overlap one another, and the fruit is contained in capsules situated in the axils of 
the leaves, or in cones formed of leaf-like bracts. These capsules are kidney-shaped, destitute of any ring, leathery in structure, and sessile ; they consist of one, two, or three cells. Some of these capsules contain powdery grains, others soft bodies generally supposed to be buds; the former style of seed is present in all Lycopods, the latter only in some species. Name from lycos, wolf, and podos, foot.

\section{Lycopodium clavatum, Linn. Common Club- Moss, or Wolf's-Claw.}

Stem procumbent, very long, branched. Leaves overlapping, toothed, with long hairs at the point. Spikes in pairs. Bracts triangular, turning back after the seed has escaped, toothed and and pointed.

The common Club-moss is a tough, wiry plant; its stems run along the ground for a distance of many feet,

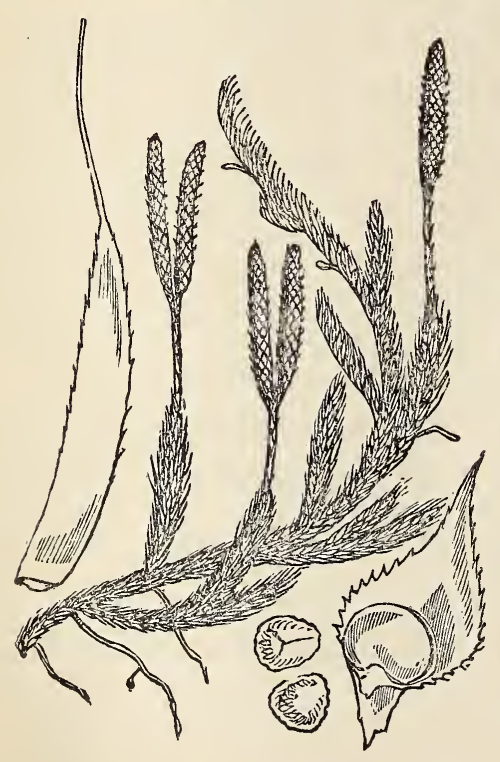
the branches crossing one another and interlacing, so as to form a perfect carpet, and procure for it in Sweden the name of matte-grass. The stem throws out pale wiry roots at short distances, which attach the plant firmly to the earth. The narrow leaves, each terminating in a long hair, are curved inwards, and at once overlap one another, and adhere closely to the stem. Footstalks arise from the end of the lateral branches, from $I$ to 3 inches long, bearing generally a pair of cones, but sometimes a single one, 
and more rarely a triplet. These cones are covered with triangular bracts, heart-shaped at the base and terminating in a sharp point; in the axils of the bracts the capsules lie concealed. When the seed is ripe, the capsules burst, the bracts turn back, and the cones assume a dishevelled appearance.

This Club-moss is a frequent inhabitant of our hills and moors, creeping along the ground beneath the tall heath and ling, or among the sward, and raising its twin cones like a pair of horns at short distances.

Pretty ornaments are formed of this plant by rustic belles and beaux in the style commemorated by Wordsworth. Linnæus describes how the Lapland boys weave it into crowns, and Tragus records the same custom with reference to German girls. In former days, Ardebil, in Persia, was famed for its fireworks, the flames rising suddenly in the air and as suddenly disappearing. Olearius ascribes this wonderful effect to the use of "Russian Plaun, a yellow dust beaten out of the Beerlap or Devil's Claw." He proceeds to describe the plant, a description which exactly tallies with that of our Wolf's-claw, and states that the cones are collected in August, then dried in a furnace, and the powder afterwards beaten out and sold by pound. Sir J. E. Smith informs us that this dust is still used in Germany to produce artificial lightning on the stage, and that it possesses a healing property when applied to the human skin. In some places it is used to fix colours in dyeing, instead of alum. It is said to be a remedy for the terrible disease called Plica Polonica.

To induce this plant to grow in the fernery, pieces of sandstone should be placed on a stratum of peat-earth, and the branches pegged firmly down; if the drainage 
is good, and the stems are left undisturbed, it may be cultivated successfully.

The common Club-moss is found throughout Europe, in North America, the West Indian Islands, among the mountains of India, at the Cape of Good Hope, and in the island of Mauritius.

\section{Iycopodium annotinum. Interrupted Club- Moss.}

Stems long and creeping. Branches tall, erect. Foliage interrupted by clusters of smaller, more compressed leaves. Leaves narrow, overlapping spikes, sessile. Bracts broad, heart-shaped, pointed, and toothed. Capsules kidney-shaped.

The Interrupted Club-moss is densely leafy. Sir J. E. Smith accounts for the interruptions of more stunted

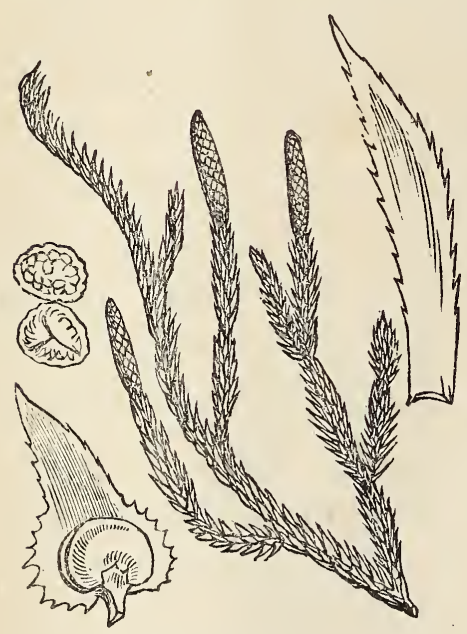
foliage by the supposition that that part was once occupied by bracts and capsules, after the ripening and decay of which the stalk continued to grow from the point of the stripped cone, and, after rising for a little distance, produced another cone of fruit, the furniture of which fell off and made way for another group of stunted leaves, a fresh elongation of stalk, and a new cone from the new apex. The roots of this Club-moss are tough and twisting, short, and fixing themselves very firmly in the earth. The stems put forth clustering branches, which grow in an erect form, increasing year by year, the interruptions marking each year's growth. The cones appear on the 
summit of the branches without any footstalk, and always singly. It is a rare species in Britain, only favouring the mountains of Scotland and Wales.

In Sweden and Norway it is very abundant; indeed, it grows freely in pine forests throughout the North of Europe and North America.

\section{Lycopodium inundatum. Marsh Club-Moss.}

Stems creeping. Branches few and short, creeping. Leaves narrow, pointed, entire at the margin. Spike solitary, sessile. Bracts broad at the base, extended into an awl-shaped point, with one sharp tooth on either side. Capsules spherical.

The Marsh Club-moss has stout, short, slightly-branching roots, and a prostrate stem very little branched. It frequents marshy ground on heaths and commons, principally in the southern counties, preferring situations where the turf has been peeled. In the winter the plant dies, all except the point of the stem, the dead plant turning black as if charred. When spring returns, the small portion which has retained its vitality begins to

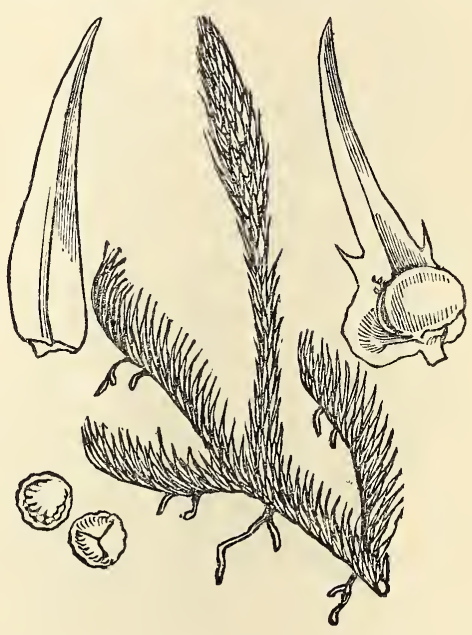
grow; presently it puts up an erect branch, about an inch in height and densely leafy, at the summit of which appears one large cone, fully as long as the branch. The stem extends yet a little further, and perhaps produces a horizontal branch before its period of decay arrives and its verdure turns to the dark dull tint, and serves to lengthen the black line left by last year's ruin. 
This Club-moss is a diminutive plant, and is therefore often overlooked.

It has been found in the temperate regions of Europe and North America.

\section{Lycopodium selaginoides. Iesser Alpine Club-Moss.}

Stems slender and delicate. Branches short, ascending. Leaves soft, broadly lanceolate, pointed, and sharply toothed. Spikes at the top of the branches, without footstalk. Bracts like the leaves, but with more numerous teeth. Capsules of two kinds.

The Lesser Alpine Club-moss is a much more tender plant than those we have already described. Its roots

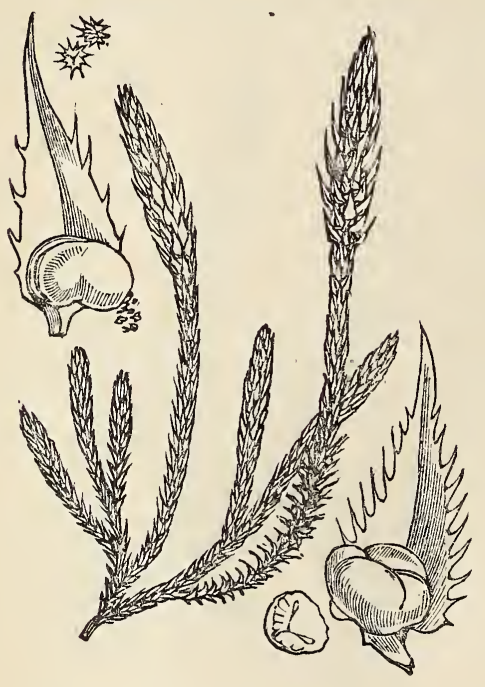
are slender and thread-like, its stem slight, weak, and repeatedly branched; the branches grow erect, and are delicate in structure; the leaves are thin, soft, and of a bright spring green. The large bracts on the spike spread widely, and reveal the bright sulphur-coloured capsules. When those near the apex burst, they give forth a cloud of yellow dust, which powders the grass and moss near to the plant. Those near the base of the spike contain larger bodies, supposed to be buds. Both the yellow spores and the buds germinate. Sir William Hooker tells us that the presence of these buds is characteristic of an allied genus called Selaginella, but the rest of its structure agrees with those of Lycopodium. 
This little Club-moss has excellent taste in its choice of habitat. On the moors in the North of England, Wales, Scotland, and Ireland, where little rivulets paint a verdant line amid the brown heather, and miniature waterfalls bubble over tiny rocks, this little Lycopod twines its stem amid the damp sand on the margin, or among the marsh mosses which affect the same locale. But it does not restrict its favour to the little brooks; we find it plentifully on the spongy margin of the lordly Tees, and many another of our northern streams, everywhere shedding its vegetable sulphur and buds, and raising its delicate progeny.

It is found in mountainous places in most European countries, and also in North America.

\section{ว3. Lycopodium alpinum. Savin-leaved Club- Moss.}

Stem long, creeping. Branches ascending, much forked, tufted. Leaves erect, overlapping, lanceolate, entire at the margin. Cone seated on the summit of the branch, solitary.

The Savin-leaved Club-moss is so called because of the resemblance of its branches to those of the Savintree, Juniperus Sabinus. It throws out its stem to a great extent, which adheres closely to the ground, and is mostly hidden by the sward; but such is not the case with the clustering branches which rise perpendicularly from the stem at short distances; their glaucous hue and plentiful forks several of them bearing one or two cones, being attractive objects. The leaves fold closely over one another, and are arranged in four rows, thereby giving a quadrangular appearance to the branches; they are concave, dilated at the base, and terminating in a 


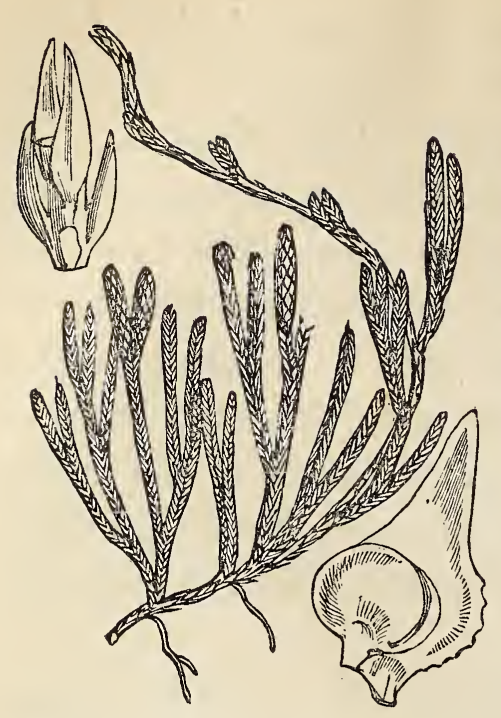

narrow but not acute point. The roots are strong and wiry, like those of the common species, and the whole has a bitter flavour and emetic properties. Sir W. J. Hooker saw it stored in Iceland, for the purpose of imparting a yellow colour to woollen goods. The spikes droop after the seed is shed, giving a still more untidy appearance to the plant than the mere decurrence of the bracts does to its congeners.

In the fernery it requires the same treatment as the Wolf's-claw.

This Lycopod grows abundantly in the hilly districts of Scotland and the North of England, preferring ground not overshadowed by heath or shrubs, and flourishing best among the sward on the hillsides.

Its foreign homes are of a boreal nature; the Alps, Pyrenees, and Vosges, indeed, boast its presence, according to Sir W. Hooker ; but it is most abundant in Siberia and Northern Asia, Lapland, Norway, and North America.

\section{Lycopodium Selago. Fir Club-Moss.}

Stems erect, rigid, abundantly branched. Branches blunt, leafy. Leaves erect, overlapping, lanceolate, sharp-pointed, with entire margin. Capsules in the axils of the upper leaves.

The Fir Club-moss has numerous, thick, wiry roots; the stem is thick and tough; the branches repeatedly forked and clustering; the leaves firm, rigid, and of 
a dark yellowish-green. The fructification is situated in the axils of the upper leaves, and contained in capsules of a kidney-shape. Besides this mode of reproduction, deci. duous buds are often formed on the summits of the branches, the leaves become converted into lobed cups, tiny transparent leaves spring up in the disk, they enlarge and put forth other leaves;

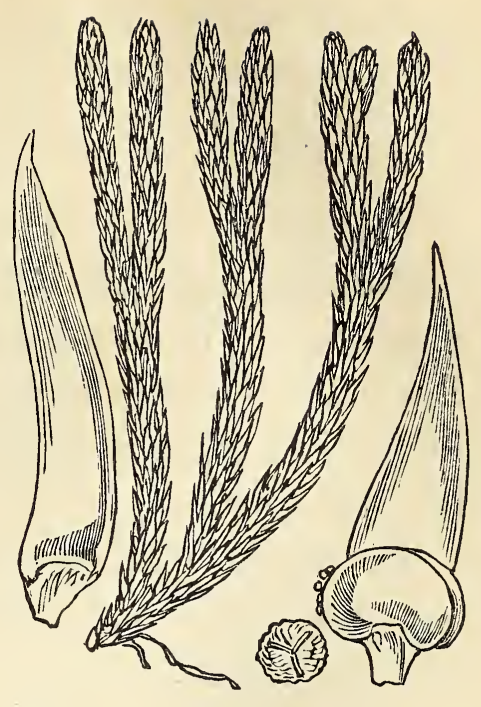
the bud thus formed falls off, strikes root, and soon rises into a stem. Sometimes it may be found growing upon the parent plant in a truly viviparous fashion.

The general aspect of the Fir Club-moss closely resembles the young state of the Norfolk Island and other pines; it is a very tough, unyielding, hardy-looking mimic of a shrub, and suits well the bleak, desolate localities which it affects. It is ever at a high elevation and on the barest rocky ground that this Lycopod flourishes best.

Its foreign homes are in the cold regions of Europe, Asia, and America.

\section{MARSILEACE $Æ$.}

\section{ISOETES.}

Gen. Char. "Capsules without a ring, indehiscent, immersed in a cavity of the very dilated base of long subulate radical leaves:- of two kinds, those at the base of the outer leaves containing a few large trigonous spores, rough with minute points 
(oophoridia); those at the base of the inner ones having numerous minute oblong granules (antheridia); in both, the contents are seen to be, at least in an early stage, attached to delicate slender filaments." - Sir W. Hooker.

The Isoetes or Quillwort family bear their capsules in the dilated base of their long awl-shaped leaves; the capsules are of two kinds, like those in some species of Club-moss, - those situated in the outer leaves being of the bud-like order, and those in the inner leaves grainlike spores.

The name is taken from two Greek words isos, equal, and etos, year,-signifying that the plant is the same all the year round.

\section{Isoetes lacustris, Linn. Quillwort, or Merlin's}

\section{Grass.}

The Common Quillwort has erect, stout, cellular

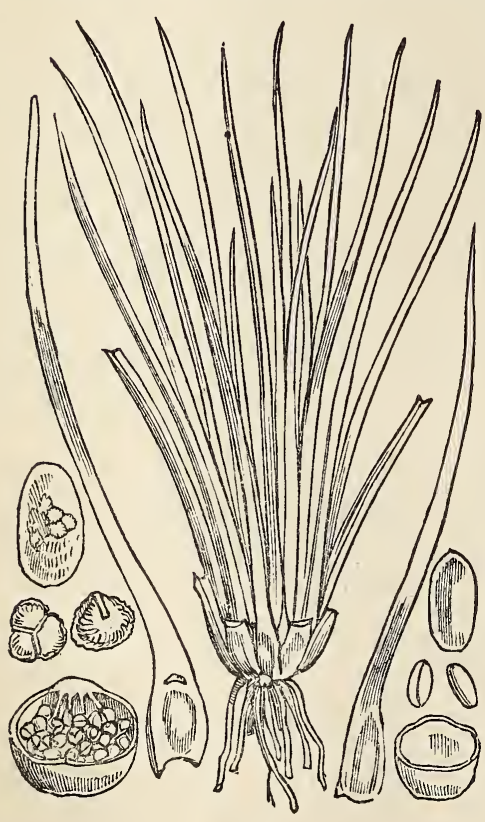

leaves; roots 3 or 4 inches in length, sometimes branched, and nearly transparent; these spring from the tuberous caudex, the crown of which bears the awl-shaped, brittle, evergreen leaves.

The Common Quillwort grows at the bottom of mountain lakes, making a kind of submerged sward. It is found in subalpine situations in all parts of the United Kingdom.

In the south of France, Sardinia, Sicily, and southern India, a species occurs with longer leaves, but Sir W. 
Hooker considers it identical with the Isoetes lacustris ; and the same distinguished botanist has it from North America, British Columbia, and South America.

\section{Isoetes Duriai, Bory. Durieu's Quillwort.}

Bulbous, scaly below. Leaves slender, spreading, and arched. Bud-like seeds granulated.

Durieu's Quillwort is a smaller plant than the common species; it grows on damp ground in southern climates, its only British habitat being in Guernsey. The leaves are not thick and erect, but slender and much curved.

This plant grows abundantly in the south of France, Algeria, and many parts of Spain. Few botanists visit the Lakes of Cumberland and Westmoreland without bringing away specimens.

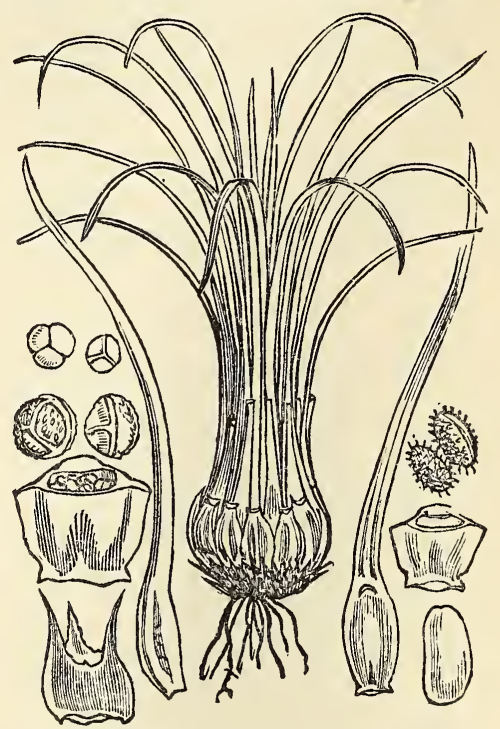

\section{PIIUIARIA.}

Gen. Char. Fructification of two kinds contained in a globular capsule, which opens by two valves at the apex.

Name from pilula, a little pill.

57. Pilularia globulifera, Linn. Common Pillwort.

Caudex creeping, rooting at short distances. Leaves slender, rush-like, and cylindrical. Capsule stalked.

The Common Pillwort creeps along ground that has 
been submerged during the winter. The caudex is

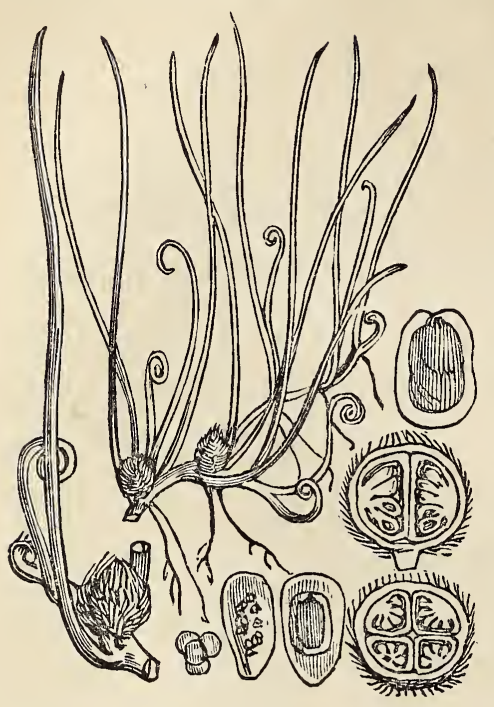
thread-like, scaly in youth, sometimes branched, and producing on its urder parts tufts of roots, and on its upper ones tufts of erect leaves, which in the early stage are curled in like the fronds of ferns; the leaves are round, hollow, and awl-shaped, bright green in colour, and composed of cells radiating from the centre. The globular capsules are placed on short stems rising from the caudex at the point where the leaves are affixed, they are about the size of a peppercorn, and are covered with brown hairs, they contain the two kinds of fruit.

This plant is found all over the United Kingdom, but is more plentiful in the south. It flourishes all over Europe, and also in Western Australia.

\section{EQUISETACE E.}

HORSETAILS.

This group of plants boasts still less resemblance to the Ferns and Club-mosses than did that of the Pepperworts, but it has gained a place as an ally of the Fern family, for want, perhaps, of any closer alliance elsewhere. The Horsetails are leafless, branching plants, with fistular stems divided by joints, each of which ter- 
minates in a toothed sheath. The fructification is contained on capsules arranged in cones. The outer skin of the stems abounds in flinty particles, placed in rows, which form ridges up the stem, the hollows between these ridges contain minute openings, or stomata.

Name from equus, horse, and seta, hair.

\section{Equisetum Telmateja, Ehrb. Great Water Horsetail.}

Barren stems stout, smooth. Ribs numerous. Branches simple and oblique. Sheaths short. Fertile stems short. Sheaths large and loose. Cone very large.

The greater Water Horsetail has a brown creeping caudex, which throws out whorls of fibrous roots at short distances. The stems are of two kinds, a third kind, uniting the peculiarities of the two, sometimes appearing late in the season.

The barren stems are erect and stately, making, as Sir J. Smith says, "a magnificent and Indian-like appearance." They are clothed from the summit to near the base with whorls of crowded branches, the branches from thirty to forty in each whorl, varying

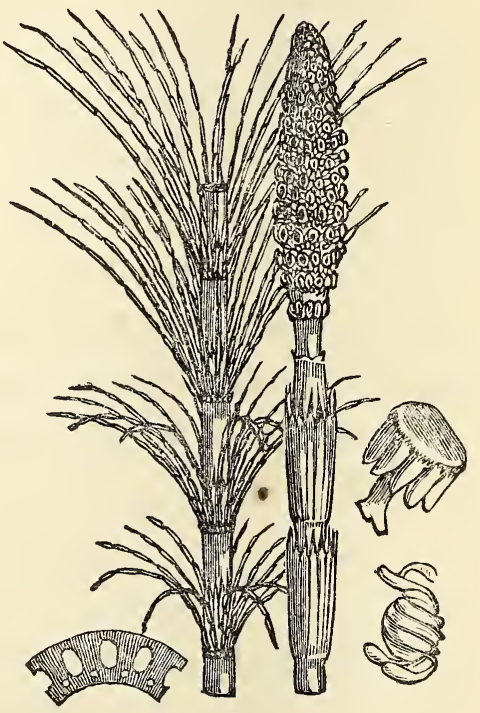
in direction from oblique to horizontal. The stems are thick and smooth, and the numerous ribs are very slight. The sheaths are close-fitting, divided at the margin into slender teeth, the same in number as the ribs of the stem, and the branches in the whorl. Each branch is 
from 8 to 10 inches long, is jointed, the joints furnished with four or five sharp teeth. The colour of the whole frond is a pale green, and attains a height of from 6 to 8 feet. The fertile stem appears in March, and ripens its cone in April, disappearing a month or six weeks later. It only grows from 8 inches to 1 foot in height. The stem is divided into about fifteen joints, the sheaths are large, loose, and pale, as well as the stem; the teeth long and slender, equal in number to those on the barren stems. The cones are very large, often $2 \frac{1}{2}$ inches long, and $1 \frac{1}{2}$ in circumference; the scales are very numerous, and the capsules attached to them are arranged in whorls. The stem is simple, and destitute of branches.

A section of the stem shows a narrow cylinder and large cavity; the exterior surface scarcely exhibits any difference between the slight ridges and furrows, but it shows two circles of openings, or stomata, those of the exterior large, and those of the interior small and alternating with the larger ones.

This handsome Horsetail is pretty frequent in watery places, besides rivers and ditches, in England. It is also found in India, North Africa, Canada, and the United States.

\section{Equisetum umbrosum, Meyer and Willd. Blunt- topped Horsetail.}

Caudex long, dark-coloured, creeping, and bearing whorls of slender roots. Barren stem terminating abruptly. Branches simple, in whorls. Fertile stem simple.

The Blunt-topped Horsetail has stems of three kinds. The barren stem has from eighteen to twenty sharp 
ridges, rough with prominent flinty particles; its sheaths are small, and about twenty in number; the branches in each whorl are the same in number, they spread widely, are simple and jointed, and beset with flinty points.

The fertile stems are only about 6 inches high, and have numerous joints, furnished with large loose sheaths, which almost cover the stem, they are slightly ribbed and pale whitish-green; the cone is oval, chestnut-coloured, first sessile, then stalked; the capsules are white, and fewer than in the last species.

The third kind of stem is branched like the barren one,

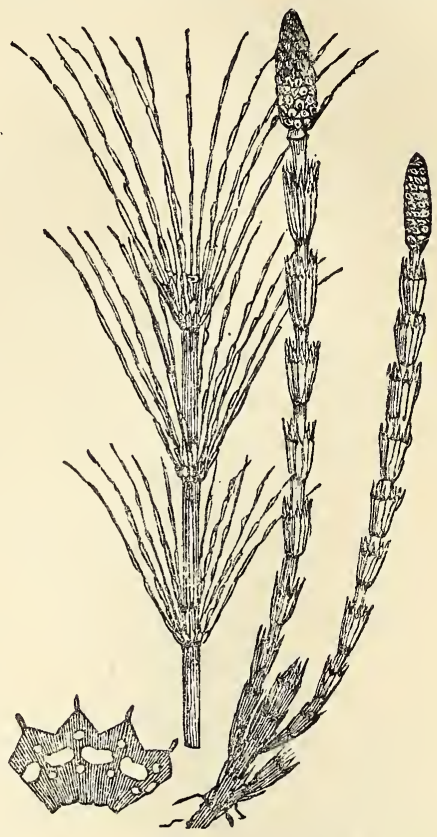
but less luxuriantly, and bears a small cone; it is intermediate in size between the two.

A section of the stem exhibits a series of sharp ridges and angular furrows on the exterior surface, and three circles of stomata, those of the two outermost circles small and circular, and those of the central one large and kidney-shaped; the central cavity is small.

This is a rare plant, but Dr. Greville has found it in Lanarkshire, Forfarshire, and near Edinburgh; others have it from near Belfast, and from several localities in Yorkshire, Westmoreland, and Northumberland.

It is generally distributed through Europe and North America. 


\section{Equisetum arvense, Linn. Field Horsetail.}

Caudex creeping. Stems of two kinds: barren roughest, ending in a point, copiously branched; fertile stout and short, simple. Cone elongated.

The Field Horsetail has a long, much branched, creeping caudex, which is cylindrical and jointed like

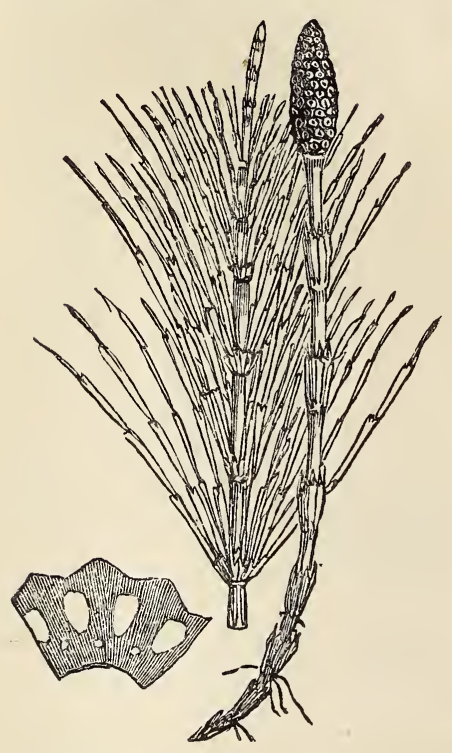

the stems, bearing its whorls of roots as they bear their whorls of branches.

The barren stems are sometimes erect, sometimes oblique, or even decumbent; they attain a height of from 2 to 3 feet, and are copiously branched along their whole extent. The furrows and ridges are from ten to sixteen, the latter studded with flinty particles; the sheaths are also. furrowed, and cut into the same number of teeth as there are ridges on the stem. The colour of the whole frond is a pale yellowish-green, the joints are about twenty-one in number, and the branches, being often 10 inches long, overlap one another, and give the frond the bushy appearance so suggestive of the English name of the family.

The fertile stem rises from the ground early in the spring, ripens its fruit, and dies down before the luxuriant barren frond attains maturity. It grows to a height of about 9 inches, has about eight joints, is succulent, pale-brown, hollow, nearly smooth, and with loose, smooth sheaths cut into about ten dark brown 
teeth. The capsules are arranged round the cone in crowded whorls, accompanied by numerous scales; the spores are of a beautiful blue-green.

A section of the stem exhibits a small central cavity, a merely undulating exterior owing to the bluntness of the ridges, and two circles of apertures, the outer large, the inner small.

This is the commonest of our Horsetails, infesting the land to a great extent, and very difficult to eradicate. It prevails chiefly where the ground is sandy, and is very injurious to cattle, owing probably to the sharp flint particles so freely immersed in its substance.

Its foreign habitat extends all over Europe and North America.

\section{Equisetum sylvaticum, Linn. Wood Horsetail.}

Caudex creeping, branched, dark-coloured. Roots slender. Barren and fertile fronds slightly different. Furrows 12. Cone blunt.

The Wood Horsetail has a caudex which creeps widely. Both the stems appear at the same time, and put forth whorls of drooping branches. The barren stem is more slender than the fertile one, the branches more numerous and more fully furnished with secondary branches. The ribs are fully developed, the sheaths fit closely, and are cut into four or five broad teeth; the whole height of the frond is from 15 to 18 inches.

The fertile ones are later in putting forth their branches, but eventually they droop, and bear secondary branches like those of the barren frond. The stems are round, succulent, and pale; 'flinty particles are imbedded in the ridges, but they are too small to cause any very 
perceptible roughness. The cone is blunt and elongated, and ripens in April.

A section of the stem reveals a series of slight ridges on the external surface, a

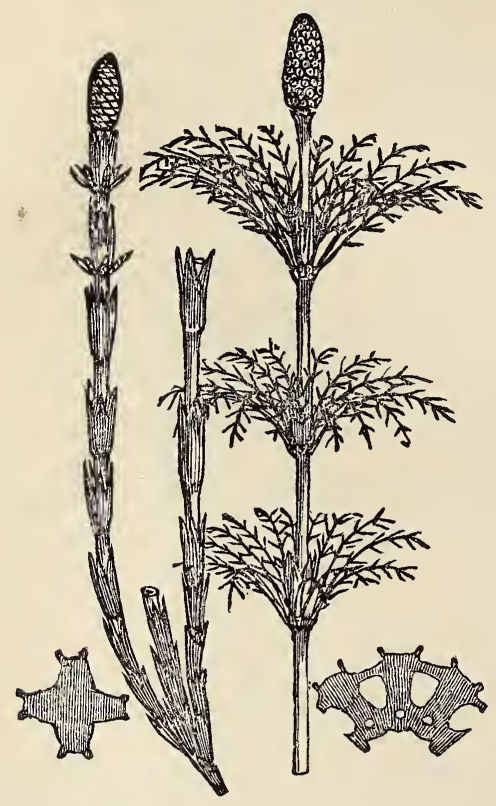
circle of large cavities in the centre of the substance of the cylinder, and also a circle of smaller ones near the internal surface.

This is the most elegant of our native Horsetails; its long drooping branches remind one of the form of some tropical cypress, and present a charming object in the subalpine thickets which it favours by its presence. It is very local, but abundant where it once settles.

It is common in the United States, Canada, and throughout temperate Europe.

\section{Equisetum limosum, Linn. Smooth Naked Horsetail.}

Caudex creeping, jointed, dark-coloured. Roots in whorls. Stems ribbed, smooth, generally simple, barren and fertile stems alike.

The Smooth Naked Horsetail puts up stems which are generally simple, but sometimes slightly branched. There are from ten to sixteen blunt ridges and sheaths, cut into the same number of dark-coloured awl-shaped teeth. The cones are oval, generally sessile, the scales 
upon them black and numerous, and the spores palecoloured.

A section of the stem exhibits a smooth outline on the exterior, a very large central hollow, and two rows of openings, the outer oval, the inner circular and very small.

This is one of the only species of use as food for cattle. Linnæus says that it is cut up and given to cows in Sweden, and that it makes the milk plentiful ; in Lapland the reindeer eat it greedily, and the people would do well to cultivate it. Mr. Knapp gives an account of a colony of short-tailed water-rats who

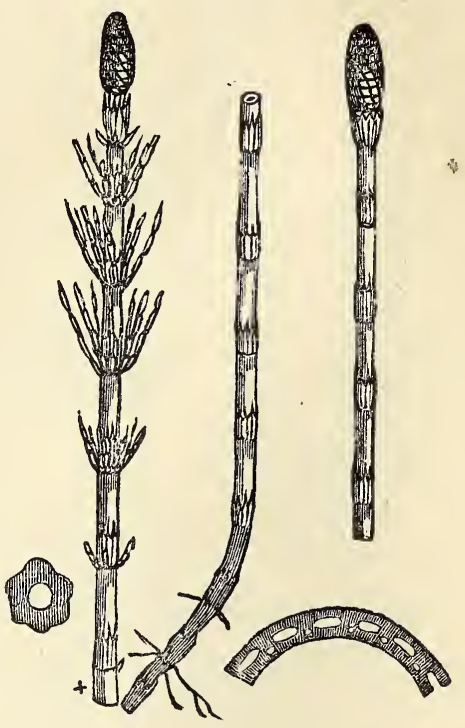
subsisted upon this plant, and as they fed upon the hard caudex the sound of their gnawing was heard at a considerable distance.

The Smooth Naked Horsetail is a common object in wet marshy grounds throughout Treat Britain, often mingling amongst the Marsh Marigold and other waterplants. It also prevails throughout Europe and North America, and wherever the climate is cold or temperate.

\section{Equisetum palustre, Linn. Marsh Horsetail.}

Caudex black, extensively creeping, and glossy. Roots slender, and repeatedly divided. Stem erect, $1 \frac{1}{2}$ feet high, furrowed four to eight times, and bearing whorls of branches. Sheaths toothed. Cones long and narrow.

The Marsh Horsetail has roughish stems and loose 
sheaths, the teeth of which are pale, wedge-shaped, and tipped with black. Both kinds of stems are sometimes

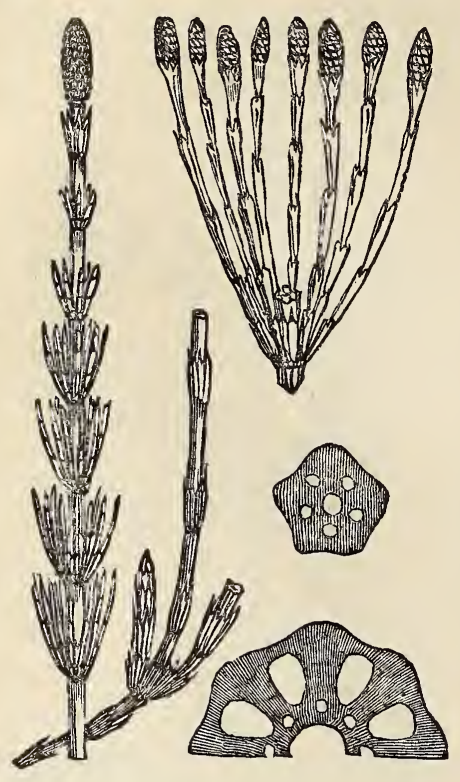
branched, the branches numerous, jointed, ascending, and with four or five ribs. The cones are oblong, an inch in length, stalked, and with many white capsules.

There is a variety called Polystachion, where each branch of the upper whorl bears a small cone.

Another variety, called nudum, has weak stems, decumbent in the lower part, and appears merely a starved plant of the Common Marsh Horsetail.

A section of the stem of this species presents a thick cylinder, very small central hollow, nearly even exterior, and two circles of apertures, each from four to eight in number, the outer larger, the inner small.

This plant is as common as the last in marshy ground all over Great Britain and other temperate regions.

\section{Equisetum hyemale, Linn. Rough Horsetail, or Dutch Rushes.}

Caudex black, branched, creeping. Stems simple, erect, rarely branched, all alike, very rough, glaucous. Cones small, dark, pointed.

The Rough Horsetail has numerous ribs, generally thirty-two, on the stem. All the stems are simple, as a rule; there are, indeed, exceptive ones, which are slightly 
branched from a joint near the base, but there is nothing approaching to a whorl. The very scales of the cone are minutely striated.

The most remarkable feature in this Horsetail is its extreme roughness, caused by the presence of closely-set rows of flint crystals, which beset it everywhere. So prevalent are these, that when the vegetable part of the stem is destroyed the form remains in crystal. Dr. Greville thus writes of it:-"On subjecting a portion of the cuticle to the analysis of polarized light under a high magnifying power, Dr. Brewster detected a beautiful arrangement of the siliceous particles, which are distributed in two lines parallel

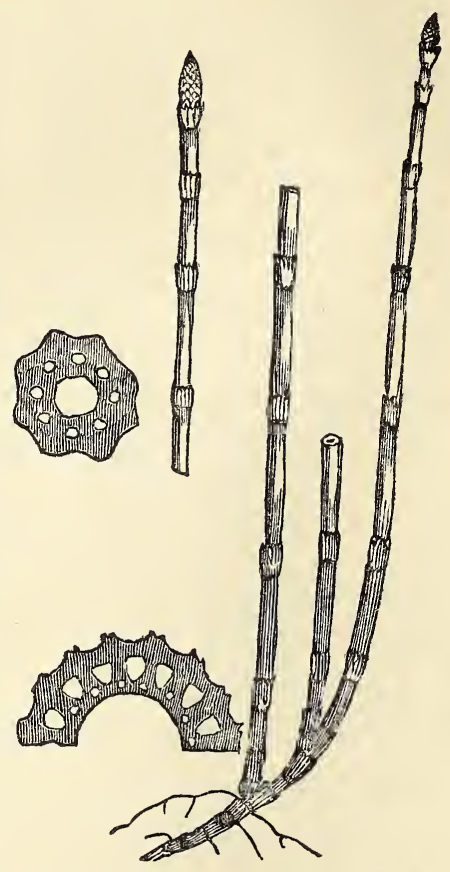
to the axis of the stem, and extending over the whole surface. The greater number of the particles form simple straight lines, but the rest are grouped into ova forms, connected together, like the jewel of a necklace, by a chain of particles forming a sort of curvilinear quadrangle; these rows of oval combinations being arranged in pairs. Many of those particles which form the straight lines do not exceed the five-hundredth part of an inch in diameter. Dr. Brewster also observed the remarkable fact, that each particle has a regular axis of double refraction. In the straw and chaff of wheat, barley, oats, and rye, he noticed analogous phenomena, but the particles were arranged in a different 
manner, and displayed figures of singular beauty. From these data Dr. Brewster concludes that the crystalline portions of silex and other earths which are found in vegetable films are not foreign substances of accidental occurrence, but are integral parts of the plant itself, and probably perform some important function in the processes of vegetable life."

A section of the stem exhibits numerous ridges on the exterior surface, varying in number and reaching as high as thirty-two; between the ridges large openings are situated in a circle, with an intervening circle of smaller apertures as in other species.

The Rough Horsetail is recommended by Galen for its astringency. It is of great use in the arts, to polish wood, bone, and metal. Lightfoot tells us that it is used by Northumbrian milkmaids to clean their pails. The Dutch rushes of commerce are imported from Holland, where they are grown upon the embankments, their branching and interlacing caudices being most useful in binding together the loose sandbanks.

It is often found in the North of England and Scotland, but is unknown in the southern and midland counties.

It is common throughout Europe, and in North Africa and America.

\section{Equisetum trachyodon, Braun. Rough-toothed Horsetail.}

Stem putting out one or two branches from joints at the base. Branches long, supple, simple, or branched once again, very rough, furrowed. Sheaths with from six to thirteen narrow teeth. Cones small, pointed.

The Rough-toothed Horsetail bears much resemblance 
to the Dutch rush, and Sir W. Hooker ranks it as intermediate between that species and the Variegated Rough Horsetail. The sheaths are pale greenish-brown in youth, but ultimately become black, and the teeth are awl-shaped.

A section of the stem shows scarcely perceptible ridges on the exterior surface, a circle of apertures large, egr-shaped, and, as usual, placed beneath the furrows, the narrower end of the egg turned inwards; and an inner circle of small round ones near the inner surface of the tube.

This plant is rare; the ha-

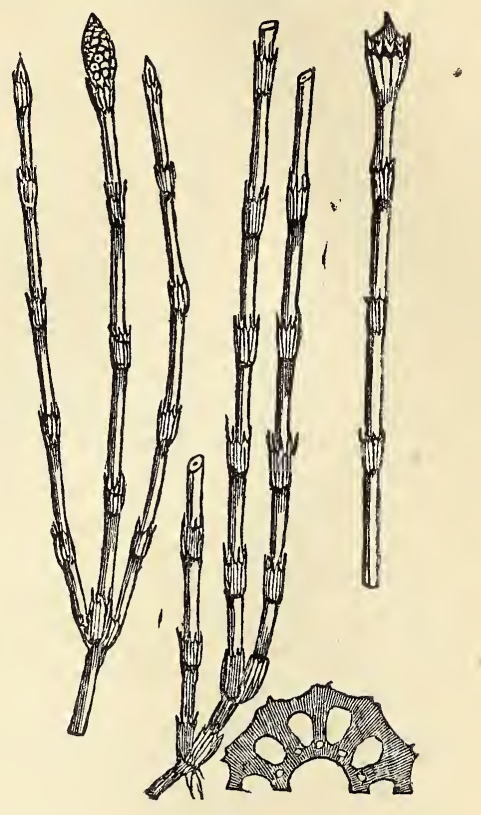
bitats ascertained are the glens of North Ireland, and the banks of the Dee.

It is also found in Germany.

Mr. Newman, Mr. Moore, and others call this species E. Mackaii.

\section{Equisetum variegatum, Schleich. Variegated. Rough Horsetail.}

Caudex widely ereeping. Stems numerous, slender, branched at the base. Sheaths with about ten bristle-pointed teeth. Cone small, generally sessile, pointed.

The stems of the Variegated Rough Horsetail are branched so freely just beneath the earth that it gives them almost a tufted appearance; the roots grow in whorls, and the branches are generally simple, though occasionally bearing one or two branchlets. It is a 
dwarf plant, the stems seldom growing higher than one foot, and often stopping far short of that stature; the

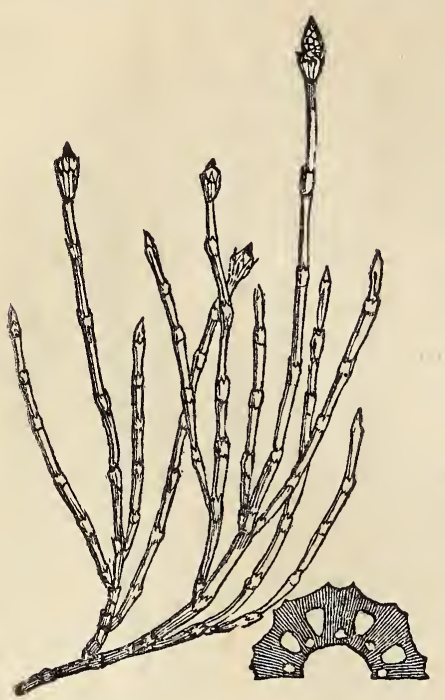
ridges on the stem are prominent from the size of the flinty particles; the sheaths are also ribbed, pale green below, and black above; the teeth awlshaped, black, with a white border. The black ring of the upper part of the teeth, its pale green base, and the white margin to the teeth has procured for this species the name variegatum.

The cone is pointed, bearing about twenty scales, and as many white capsules.

In a section of the stem we observe a small central cavity, ridges well-defined by two prominent rows of crystals, a circle of egg-shaped apertures placed beneath the furrows but nearer to the inner than the outer surface, and the second circle of smaller apertures rather alternating with the larger than placed within it as in other species.

This plant generally inhabits maritime regions, damp sands, and ditches in such localities.

This species bears a close resemblance to the allied ones, $\boldsymbol{E}$. hyemale and $\boldsymbol{E}$. trachyodon, and many learned botanists regard them as varying forms of the same species. 


\section{CHAPTER XI.}

LOCAL DISTRIBUTION OF FERNS AND THEIR ALLIES.

IN tracing out the geographical range of the Ferns in the British Isles, we shall follow the plan originated by Mr. Watson, and improved upon by Mr. Moore, of dividing the kingdom into provinces, and shall in other respects avail ourselves of the valuable aid of Mr. Moore, as of a well-skilled pioneer.

According to this plan, we trace a central line from the south coast of England to the Caledonian Canal, making the line adapt itself to the boundaries of counties, thus cutting the island of Great Britain into two divisions. We partition off the divisions into provinces, - each one watered by some river, more or less important. The various homes of the species are collected from the notes of all the most eminent writers on the subject, and from those of the leading botanists, Mr. Moore's list serving as the foundation for the structure. The following are the provinces which, according to the above plan, Great Britain and Ireland are divided into-

1. Peninsula. Cornwall, Devon, Somerset.

2. Channed. Hants, Sussex, Dorset, Wilts.

3. Thames. Herts, Middlesex, Kent, Surrey, Berks, Oxford, Bucks, Essex. 
4. Ouss. Huntingdon, Bedford, Suffolk, Norfolk, Cambridge, Northampton.

5. Severn. Warwick, Gloucester, Monmouth, Hereford, Worcester, Stafford, Salop.

6. South Wales. Radnor, Brecon, Glamorgan, Carmarthen, Pembroke, Cardigan.

7. North Wales. Anglesea, Denbigh, Flint, Montgomery, Merioneth, Carnarvon.

8. Trent. Leicester, Rutland, Lincoln, Notts, Derby.

9. Mersey. Cheshire, Lancashire.

10. Humber. York.

11. Trne. Durham, Northumberland.

12. Lakes. Westmoreland, Cumberland, and north of Lancashire, Isle of Man.

13. West Lowlands. Dumfries, Kircudbright, Wigton, Ayr, Renfrew, Lanark.

14. East Lowlands. Peebles, Selkirk, Roxburgh, Berwick, Haddington, Edinburgh, Linlithgow.

15. West Highlands. Inverness, west of Loch Erricht, Argyle, Dumbarton, and the Isles adjacent from Bute and Arran to Skye.

16. East Highlands. Stirling, Clackmannan, Kinross, Fife, Perth, Forfar, Kincardine, Aberdeen, Banff, Nairn, Elgin or Moray.

17. North Highlands. Ross, Cromarty, Sutherland, Caithness.

18. Northern Isles. Orkney, Shetland.

19. Western Isles. Outer Hebrides.

20. Ulster (North). Antrim, Londonderry, Donegal, Tyrone, Down, Armagh, Monaghan, Fermanagh, Cavan.

21. Connaught (West). Leitrim, Sligo, Galway, Roscommon.

22. Leinster (East). Longford, Westmeath, Meath, 
Louth, Dublin, Kildare, King's County, Queen's County, Wicklow, Wexford, Carlow, Kilkenny.

23. Munster (South). Waterford, Tipperary, Clare, Limerick, Cork, Kerry.

24. Channel Isles. Guernsey, Jersey.

\section{LOCALITIES OF FERNS.}

\section{ADIANTUM CAPILLUS-VENERIS.}

Peninsula. Carelew, and near St. Ives, Cornwall. Ilfracombe; Watermouth; Brixham; Newstone Bay, Devonshire.

South Wales. Dunraven; East Aberthaw, Swansea.

Barry Island, Glamorganshire.

West Highlands. Argyleshire.

Connaught. Near Urisby; Roundstone, Connemara, Galway. Arran Isles.

Munster. Near Tralee, Kerry.

\section{ASPIDIUM ACULEATUM.}

Peninsúla. Cornwall. Lynmouth; Totnes; Ashburton, Devonshire. Portishead, Somersetshire.

Channer. Selborne; Alresford, Hampshire. Isle of Wight. Dorsetshire. Box Quarries, Wilts. Henfield; Groombridge, Sussex.

Thames. St. Alban's; Totteridge ; Hitchin ; Essendon, Hertfordshire. Middlesex. Kent. Mayford and Dorking, Surrey. Chalfont; Fulmer, Buckinghamshire. Berkshire. Oxfordshire. Near Ongar; Brentwood; Chingford; Black Notty, Essex. 
Ouse. Sudbury, Suffolk. Yarmouth; Edgefield, near Holt, Norfolk. Gamlingay, Cambridgeshire. Bedfordshire. Northamptonshire.

Severn. Stoneleigh; Allesley; Hollyberry End and Wyken Lane, and elsewhere, Warwickshire. Herefordshire. Knightwick, Worcestershire. Stafford. shire. Shropshire.

South Wales. Tenby, Pembrokeshire. Carmarthenshire. Glamorganshire.

North Wales. Anglesea. Wrexham, Denbighshire. Llyn-y-cwm, Carnarvoushire.

Trent. Leicestershire. Mansfield; Papplewick, Nottinghamshire. Matlock, and elsewhere, Derbyshire. Lincolnshire.

Mersey. Gateacre, near Liverpool; Hail Wood, Lancashire. Rostherne; Prenston, Cheshire.

Humber. Halifax; Castle Howard Woods ; Richmond; Wensleydale; Swaledale; Studley; Roche Abbey; Settle; Ripon; Doncaster; York; Ingleborough, Yorkshire.

Trne. Hexham and Scotswood Denes, Northumberland. Cawsey Dene; Teesdale, near Croft, Durham. Lakes. Cumberland. Westmoreland.

West Lowlands. Drumlanrig; Nithdale, and other parts of Dumfriesshire. Kircudbrightshire. Renfrewshire. Lanarkshire.

East Lowlands. Edinburghshire. Near Kelso and Jedburgh, Roxburghshire. Pease Bridge, Berwickshire. West Highlands. Argyleshire. Bute; Arran; Isles of Islay and Cantire.

East Highlands. Glen Phee, Clova Mountains, and other parts of Forfarshire. St. David's, Fifeshire. Glenfarg, near Perth, Perthshire. 
Ulster. Glen Colin; Malone; Belfast, Antrim. Channel Isles. Jersey.

Var. angulare. Lynmouth; Totnes, Devon. Bath, Somersetshire. Stubbington; Uplands; Caltisfield, and elsewhere, Hants. Isle of Wight. Dorsetshire. Wilts. Patching; Findon, Sussex. Pashanger; Hatfield Woodrib; Colney; Watford ; Totteridge, Hertfordshire. Everywhere in Kent. St. Martha's, Guildford, Surrey. Epping; Springfield, Essex. Norfolk. Huntingdonshire. Bristol; Forest of Dean, Gloucestershire. Stoneleigh; Berkeswell ; Hearsall, Warwickshire. Ross, Herefordshire. Eartham, Worcestershire. Staffordshire. Shropshire. Tenby, Pembrokeshire. Gomer, Glamorganshire. Cardiganshire. Conway, Carnarvonshire. Denbighshire. Matlock, Derbyshire. Leicestershire. Prescott; Hailwood; Prestwich Clough, Lancashire. Cheshire. Edlington Crags, near Adwick; Roche Abbey; Halifax; Richmond; Hackfall ; Middleham ; Elland, and elsewhere in Yorkshire. Longbrigg Fell ; Ambleside; Westmoreland. Isle of Man. Peasebridge, Berwickshire. Blackstaff Lane; Colin Glen, Belfast. Antrim ; Arran Isles, Galway. Tinnahiuch, Wicklow. Clonmel, Cork. Jersey.

Var. lobatum. Ashburton, Devon. Portishead; Goblin Combe; Yatton, near Frome, Somerset. Selborne, Hants. Isle of Wight. Wilts. Groombridge, Sussex. Kent, everywhere. Mayford; Dorking, and elsewhere, Surrey. Chalfont, and elsewhere in Berkshire. Oxfordshire. Essex. Sudbury, Suffolk. Yarmouth, and elsewhere, Norfolk. Northamptonshire. Warwickshire. Bristol, and elsewhere in Gloucestershire. Staffordshire. Mannington, and elsewhere in Shrop- 
shire. Glamorganshire. Denbighshire. Leicestershire. Nottinghamshire. Derbyshire. Lincolnshire. Lancashire. Cheshire. Yorkshire, everywhere. Northumberland. Teesdale, about Croft and elsewhere, Durham. Cumberland. Westmoreland. Dumfriesshire. Kircudbrightshire. Lanarkshire. Edinburghshire. Roxburghshire. Berwickshire. Forfarshire. Kincardineshire. Aberdeenshire. Morayshire. Isles of Islay, Bute, Arran, and Cantire. Ross-shire. Glen Colin, Malone, Antrim.

Var. multifidum. Suffolk and Somersetshire.

Var. micaceum. Barnstaple, Devon.

Var. furcatum. Devon.

\section{ASPIDIUM IONCHITIS.}

North Wales. Clogwyn-y-Garnedd; Cwm Idwal; Twll-du ; Glyder-Vawr ; above Llanberis, Carnarvonshire.

Tyne. Falcon Clints, Teesdale?; Mazebeck Scar, Durham.

East Highlands. Ben Lomond, Stirlingshire. Ben Lawers; Craig Challiach; Glen Lynn; Ben Chouzie, near Crieff, Perthshire. Caulochen; Glen Isla; Glen Phee; Glen Dole; Clova Mountains, Forfarshire. Aberdeenshire. Morayshire.

West Highlands. Ben Voirlich, Dumbartonshire. Mountains near Loch Erricht, Inverness-shire. Ben More, Isle of Mull.

North Highlands. Raven Rock, near Castle Lead, Ross-shire. Ben Hope; Assynt, Sutherlandshire. North Isles. Hay Hill, Orkney. 
Ulster. Glen, east of Lough Eske; Rosses and Thanet mountain-passes, Donegal.

Connaught. Glenade Mountain, Leitrim. Ben Bulben, Sligo.

Munster. Brandon Mountain, Kerry.

\section{ASPLENIUM ADIANTUM-NIGRUIM.}

Peninsula. Cornwall, Devonshire, Somersetshire.

Channel. Hants, Sussex, Dorset, Wilts.

Thames. Herts, Middlesex, Kent, Surrey, Berks, Oxford, Bucks, Essex.

Ouse. Bedford, Suffolk, Norfolk, Cambridgeshire, Northamptonshire.

Severn. Warwickshire, Gloucestershire, Herefordshire, Worcestershire, Staffordshire, Shropshire.

South Wales. Glamorganshire, Carmarthenshire, Pembrokeshire, Cardiganshire.

North Wales. Anglesea, Denbighshire, Merionethshire, Flintshire, Carnarvonshire.

Trent. Leicesterșire, Rutland, Nottinghamshire, Derbyshire.

Mersey. Cheshire, Lancashire.

Humber. Yorkshire.

Trne. Durham, Northumberland.

Lakes. Westmoreland, Cumberland, North Lancashire. West Lowlands. Dumfriesshire, Kircudbrightshire, Ayrshire, Lanarkshire, Renfrewshire.

East Lowlands. Roxburghshire, Berwickshire, Edinburghshire, Linlithgowshire.

East Highlands. Clackmannanshire, Kinross-shire, Fifeshire, Perthshire, Forfarshire, Kincardineshire, Aberdeenshire, Banffshire, Morayshire, Nairnshire. 
West Highlands. Inverness-shire, Argyleshire, Dumbartonshire, Isles of Islay, Cantire, Arran, Bute and Iona and Ailsa Craig.

North Highlands. Cromarty, Sutherlandshire, Caithness.

North Isles. Orkney.

West Isces. Tarbet, Harris.

Ulster. Antrim, Down.

Connaught. Galway, Arran Isles.

Munśter. Kerry, Cork.

Channel Isles. Jersey.

\section{ASPIENIUM CETERACH.}

Peninsula. Trevenna; Truro; Newlyn; Calstock; Pentillie Castle, Cornwall. Topsham; Torquay; Babbicombe; Plymouth, Devonshire. Breamdown; Clevedon; Cheddar; Weston-super-Mare; Yatton; Frome, Somersetshire.

Channel. Winchester Cathedral; Netley Abbey ; Selborne; Botley, etc., Hants. Brading; Carisbrooke Castle, etc., Isle of Wight. Sherborne, Dorsetshire. Corsham, and elsewhere in Wiltshire. Pulborough; Enfield; Hurstpierpoint; Stopham; Marden; Chailey, etc., Sussex.

Thames. Herts. Riverhead; Maidstone, Kent. Westbrooke; Godalming; Haslemere; Farnham, Surrey. Cowley, Oxfordshire. Essex.

Severn. Tachebrook; Coventry, Warwickshire. Stapleton; Chepstow ; Cheltenham; Cirencester, Gloucestershire. Tintern Abbey, Pontypool, Monmouthshire. Hereford; Ross; Leominster, Herefordshire. 
Malvern; Badsey; Wychwood Forest, Worcestershire. Welton ; Berresford; Beeston Tor, Staffordshire. Ludlow, Shropshire.

South Wales. Brecon; Talgarth ; Crickhowel, Brecknockshire. Aberdare; Cardiff; Swansea Gower; Pennard Castle, Glamorganshire. Carmarthenshire. Tenby, Pembroke, and Manorbeer Castles; Haverfordwest Priory, Pembrokeshire.

North Wales. Holyhead, Anglesea. Denbighshire. Barmouth, Merionethshire. Trebroth; Bangor ; Carnarvon, Carnarvonshire.

Trent. Colwick Park; Papplewick, Nottinghamshire. Dovedale; Newton near Melbourne; Lath Killdale, Derbyshire.

Mersey. Carr-edge, Cheshire. Lancaster; Club-moor, near Liverpool; West Houghton; Kellet, north of Manchester, Lancashire.

Humber. Rocks behind Malharn; Kirklees Park, near Halifax, Yorkshire.

Tyne. Northumberland.

Lakes. Arnside Knot; Milnthorpe ; Kendal ; Castleton; Ambleside, Westmoreland. Sandwith; St. Bees ; Gowbarrow Park; Ulswater, Cumberland. Silverdale, North Lancashire.

West Lowlands. Drumlanrig, Dumfriesshire. Orchardton Buit, Kircudbrightshire. Paisley, Renfrewshire. Glasgow, Lanarkshire.

East Highlands. Kinnoul Hill; Dens of Balthayock and Pitroddie, Perthshire.

West Highlands. Kilfinnan, Argyleshire.

Ulster. Galgorm; Cave-hill, Antrim. Bryansford, Down. Florence Court, Fermanagh.

Connaught. Drumahore; Friarstown Abbey, near Sligo. 
Roundtower of Roscommon, between Galway and Oughterard; near Mohir; Oughterard; and many other parts of Galway. Arran Isles.

Leinster. Marlay, coast near Dublin. Glendalough, Wicklow. Marble quarries at Kilkenny.

Munster. Between Clonmel and Waterford, and many parts of Waterford. Castle-Connel and elsewhere, Clare. Cork, Clonmel, etc., Cork. Limerick. About Killarney, Kerry.

Channel Isles. Jersey.

\section{ASPLENIUM FILIX-FGEMINA.}

Peninsula. Cornwall, Devon, Somerset.

Channel. Isle of Wight, Hants, Dorset, Wilts, Sussex. Thames. Herts, Kent, Surrey, Oxfordshire, Essex.

Ouse. Suffolk, Norfolk, Cambridgeshire, Bedfordshire. Severn. Warwickshire, Gloucestershire, Monmouthshire, Worcestershire, Staffordshire, Shropshire.

South Wales. Brecknockshire, Glamorganshire, Carmarthenshire, Pembrokeshire.

North Wales. Anglesea, Denbighshire, Flintshire, Carnarvonshire.

Trent. Leicestershire, Nottinghamshire, Derbyshire, Rutland.

Mersey. Cheshire, Lancashire.

Humber. Yorkshire.

Tyne. Northumberland, Durham.

LaKes. Kenwick, Westmoreland.

West Lowlands. Dumfriesshire, Kircudbrightshire, Renfrewshire, Lanarkshire.

East Lowlands. Edinburghshire, Jedburgh, Roxburghshire, Berwickshire. 
East Highlands. Clackmannanshire, Fifeshire, Aberdeenshire, Banffshire, Morayshire.

W est Highlands. Inverness-shire, Argyleshire, Dumbartonshire, Isles of Islay, Cantire, Arran, and Bute. North Highlands. Cromarty, Sutherlandshire, Caithness.

North Isle. Orkney.

West Isles. North Uist, Harris, Lewis.

Ulster. Everywhere.

Munster. Everywhere.

Leinster. Everywhere.

Connaught. Everywhere.

Channel Isles. Guernsey and Jersey.

Var. connexum. Trevenna, Cornwall. Tunbridge Wells. Arbury Park, Warwickshire. Shropshire. Aber, Carnarvonshire. Mickley Barrows, Yorkshire. Dalnacardock, Perthshire. Arran, Killarney.

Var. latifolium. Salterton, Devon. Keswick, Cumberland.

Var. molle. Brodrick, Arran.

Var. marinum. Sea-coast near Aberdeen.

Var. multifidum. Wicklow.

\section{ASPLENIUM FONTANUM.}

Trent. Matlock, Derbyshire.

East Highlands. Near Stonehaven, Kincardineshire.

ASPLENIUII GERMANICUM.

North Wales. Rocks near Llanrwst, Denbighshire. Lakes. Borrowdale, Cumberland. 
East Lowlands. Rocks on the Tweed, Roxburghshire. East Highlands. Dumfermline, Fifeshire. Dunkeld, Perthshire.

\section{ASPLENIUM LANCEOLATUM.}

Peninsula. Penzance; St. Ives, Cornwall. Morwell Rocks, Banks of the Tavy, the Plym; Brickland ; Tavistock; Saleshube; Torquay; Bickleigh Vale, Devon. Somersetshire.

Channel. Tunbridge Wells?

Severn. Pennant Rocks, near Stapleton.

South Wales. Ramsay Island, Pembrokeshire. Glamorganshire.

North Wales. Barmouth, Merionethshire. Tremadoc; Beddgelert; Aberglaslyn, Carnarvonshire. Llanrwst, Denbighshire.

Channel Isles. Guernsey, Jersey.

\section{ASPLENIUMI MARINUM.}

Peninsula. Cornish and Devon coast. Somersetshire coast.

Channel. Isle of Portland; Purbeck; Lyme Regis, Dorset. Isle of Wight. Castle Rock at Hastings.

South Wales. Swansea; Dunraven; Neath; Oystermouth; Barry Island, Glamorganshire. Tenby; Fishguard; St. David's; St. Catherine's Island; Pembrokeshire. Aberystwith, Cardiganshire.

North Wales. Llanddwyn; Holyhead, Anglesea. Towyn, Merionethshire. Carnarvon Castle. Orme's Head; Bangor, Carnarvonshire. 
Mersey. Red-roses Rock; New Brighton; Helbre Island, mouth of the Dee, Cheshire. Warrington; Newton; Liverpool; Heysham, Lancashire.

Humber. Cliffs north of Scarborough, Yorkshire.

Trne. Marsden Rocks; Blackhall Dean, west of Hartlepool. Teesdale, Durham. Ilswick, Northum berland. Holy Island.

Lakes. Silverdale, Westmoreland. St. Bees Head, Cumberland. Morecombe Bay, North Lancashire. Isle of Man.

West Lowlands. Kircudbrightshire, Wigtonshire, Ayrshire.

East Lowlands. Berwickshire. Queensferry,Edinburgh. East Highlands. Weemyss, Fifeshire. Montrose; Dysart, Forfarshire. Kincardineshire. Aberdeenshire. Morayshire.

West Highlands. Isles of Bute, Islay, Cantire, Arran, Staffa, Iona, Skye, and Ailsa Craig.

North Highlands. Nigg, Ross-shire. Farr, Sutherlandshire. Wick; Thurso, Caithness.

Northern Isles. Orkney.

Western Isles. Little Barne; Harris; Sheant Isles. Ulster. Newcastle, Down. Isle of Rathlin. Mullaghmore, Cavan.

Connaught. All along the coast.

Leinster. Howth, Killiny Bay.

Munsrer. Killarney; Derrynane, Kerry. South coast.

Clonmel, Cork.

Channel Isles. Guernsey, Jersey.

ASPLENIUM RUTA-MURARIA.

Peninsula. Cornwall, Devon, Somerset. 
Channer. Dorset, Wilts, Isle of Wight, Hants, Sussex. Thames. Herts, Middlesex, Kent, Surrey, Berks, Bucks, Oxfordshire, Essex.

Ouse. Suffolk, Norfolk, Cambridgeshire, Bedfordshire. Severn. Warwickshire, Gloucestershire, Herefordshire, Shropshire, Worcestershire, Staffordshire.

South Wales. Glamorganshire, Carmarthenshire, Pembrokeshire.

North Wales. Anglesea, Denbighshire, Merionethshire, Carnarvonshire.

Trent. Leicestershire, Nottinghamshire, Derbyshire, Rutland.

Mersey. Cheshire, Lancashire.

Humber. Yorkshire.

Tyne. Northumberland, Durham.

Lakes. Cumberland, Westmoreland.

West Lowlands. Dumfriesshire, Kircudbrightshire, Renfrewshire, Lanarkshire.

East Lowlands. Berwickshire, Edinburghshire, Linlithgowshire.

West Highlands. Argyleshire, Dumbartonshire, Ailsa Craig, Islay, and Cantire.

East Highlands. Stirlingshire, Clackmannanshire, Perthshire, Fifeshire, Forfarshire, Kincardineshire, Aberdeenshire, Banffshire, Morayshire, Nairnshire.

North Highlands. Cromarty, Sutherlandshire, Caithness.

Northern Isles. Orkney.

Western Isles. North Uist, Harris, Lewis.

Connaught. Arran Isles, Galway.

Munsthr. Cork.

Channel Isles. Jersey. 


\section{ASPIENIUM SEPTENTRIONALE.}

Peninsula. Culbone, Somersetshire.

North Wales. Llanrwst, Denbighshire. Craig Du, near Llanberis ; Llyn-y-cwm; Capel Curig; Carnedd Llewellyn, Carnarvonshire.

Humber. Ingleborough.

Trne. Kyloe Crags, Northumberland.

LAKes. Honister Crags; Scaw-fell; Patterdale; Keswick; Borrowdale; Vale of Newlands, Cumberland. Ambleside, Westmoreland.

East Lowlands. Minto Crags, Jedburgh, and rock by the Tweed near Kelso, Roxburghshire. Arthur's Seat, Edinburgh.

East Highlands. Dunkeld, Perthshire.

Northern Isles. Orkney.

\section{ASPIENIUM TRICHOMANES.}

Peninsula. Cornwall, Devon, Somerset.

Channel. Isle of Wight, Hants, Wilts, Dorset, Sussex. Thames. Herts, Kent, Isle of Sheppey, Surrey, Buckinghamshire, Oxfordshire, Essex.

Ouse. Suffolk, Norfolk, Cambridgeshire, Bedfordshire. Severn. Warwickshire, Gloucestershire, Herefordshire, Worcestershire, Shropshire, Staffordshire.

South Wales. Glamorganshire, Carmarthenshire, Pembrokeshire.

North Wales. Anglesea, Denbighshire, Montgomeryshire, Merionethshire, Carnarvonshire.

Trent. Leicestershire, Nottinghamshire, Derbyshire, Rutland.

Mersey. Cheshire, Lancashire. 
Humber. Yorkshire.

Trne. Durham, Northumberland.

Lakes. Westmoreland, Cumberland, Isle of Man.

West Lowlands. Dumfriesshire, Kircudbrightshire, Renfrewshire, Lanarkshire.

East Lowlands. Roxburghshire, Berwickshire, Edinburghshire, Linlithgowshire.

West Highlands. Argyleshire, Dumbartonshire, Isles of Islay and Cantire.

EASt Highlands. Stirlingshire, Clackmannanshire, Fifeshire, Perthshire, Forfarshire, Kincardineshire, Aberdeenshire, Morayshire, Nairnshire.

North Highlands. Ross-shire, Cromarty, Sutherlandshire.

Northern Isles. Orkney.

IrELAND. Very common everywhere.

\section{ASPLENIUM VIRIDE.}

Severn. Ham Bridge, Worcestershire. Staffordshire. South Wales. Near Brecon; Capel-y-Fin; Capel Colbren, Brecknockshire. Merthyr Tydvil; Cilhepste Waterfall ; Darran-yr-Ogof, Glamorganshire.

North Wales. Cader Idris, Merionethshire. Cwm Idwal; Twlldu ; Llyn-y-cwm; Clogwyn-du-Yrarddu, Carnarvonshire.

Trens. Buxton; Coverdale; Castleton, Derbyshire. Charley Forest; Beacon Hill, Leicestershire.

Mersey. Carr Edge, Cheshire. Staley, Lancashire. Humber. Settle; Craven; Ingleborough; Gordale; Widdal Fell; Wensleydale; Ogden Clough, Halifax; Reeth Moor; Butter-tubs Pass, Swaledale, and other parts of Yorkshire. 
Trne. Falcon Clints, Teesdale; Weardale, Durham. Banks of the Irthing, Northumberland.

Lakes. Rocks above Patterdale; Kendal; Farlton; Arnside; Casterton; Marlbeck Scar, Westmoreland. Ashness Gill; Borrow Force; Gilsland, Cumberland. West Lowlands. Moffat, Dumfriesshire. Falls of the Clyde, Lanarkshire.

East Highlands. Stirlingshire. Ben Chouzie, near Crieff; Blair Athol ; Ben Lawers, Perthshire. Cunlochen; Clova, Forfarshire. Nairnshire, Aberdeenshire.

West Highlands. Inverness-shire, Argyleshire, Isle of Mull.

North Highlands. Assynt, Sutherlandshire. Rosshire. Ulster. Near Lough Esk, Donegal.

Connaught. Ben Bulben, Sligo.

Munster. Bandon, Cork. Turk Mountain, Kerry.

\section{BLECHNUM BOREALE.}

Peninsula. Cornwall, Devonshire, Somersetshire. Channel. Hants, Isle of Wight, Dorsetshire. Thames. Herts, Kent, Surrey, Middlesex, Berkshire, Oxfordshire, Essex.

Ouse. Suffolk, Norfolk, Cambridgeshire, Bedfordshire, Northamptonshire.

Severn. Warwickshire, Gloucestershire, Monmouthshire, Herefordshire, Worcestershire, Staffordshire, Shropshire.

Soutu Wales. Brecknockshire, Glamorganshire, Carmarthenshire, Pembrokeshire.

North Wales. Anglesea, Denbighshire, Flintshire, Merionethshire, Carnarvonshire. 
Trent. Leicestershire, Rutland, Lincolnshire, Nottinghamshire, Derbyshire.

Mersey. Cheshire, Lancashire.

Humber. Yorkshire.

Trne. Durham, Northumberland.

Lakes. Westmoreland, Cumberland.

West Lowlands. Dumfriesshire, Kircudbrightshire, Renfrewshire, Lanarkshire.

East Lowlands. Roxburghshire, Berwickshire, Edinburghshire.

West Highlands. Inverness-shire, Argyleshire, Dumbartonshire, Isles of Islay and Cantire.

East Highlands. Clackmannanshire, Fifeshire, Kinross-shire, Perthshire, Forfarshire, Kincardineshire, Banffshire, Morayshire, Inverness-shire.

North Highlands. Ross-shire, Cromarty, Caithness, - Sutherlandshire.

Northern Isles. Orkney.

Western Isles. North Uist, Harris, Lewis.

Connaught. Arran Isles.

Leinster. Wicklow.

Munster. Cork, Clare.

Channel Isles. Jersey.

\section{BOTRYCHIUM LUNARIA.}

Peninsula. Cardynham, Cornwall. Near Barnstaple; by the Dart; Haldown Hill, Devon. Bath, Somerset. Channel. Titchborne; New Alresford; Hinton, Hants. Luccomb; Shanklin, Isle of Wight. Patching; Storrington; Croboro' Warren, Sussex. Wilts. Sturminster Newton, Dorset. 
Thames. Dartford; Chislehurst ; Foot's Cray, Kent. Reigate; Shear; Albury; Dorking; Shirley; Godalming; Farnham Park, Surrey. Shotover Hill; Winchwood Forest, Oxfordshire.

Ouse. Oakley Westfield, Bedfordshire. Bury, Suffolk. Heveringham Heath; Stratton Heath; Seething, Norfolk. Little Linton; Balsham; Chippenham, Cambridgeshire. Halston Heath; Wouldfield, Northamptonshire.

Severn. Moxhall; near Coleshill Pool, Warwickshire. Gloucestershire. Herefordshire. Oversley Hill, near Amester; Stourbridge, Worcestershire. Cheadle; Farley, Staffordshire. Stollerton; Titterstone Clee Hill ; Ludlow, Shropshire.

South Wales." Glamorganshire.

North Wales. Anglesea; Wrexham, Denbighshire. Near Rodney's Pillar, Montgomeryshire. Penmaen Mawr, Carnarvonshire.

Trent. Rutland. Loughborough; Market Harborough; Ashby-de-la-Zouch; Twycross, Leicestershire. Lincolnshire. Sutton-on-Trent; Newstead ; Clifton; Paplewick ; Norton ; Sherwood Forest, Nottinghamshire. Buxton; Masson, near Matlock, Derbyshire.

Mersey. Near Over; New Brighton; Macclesfield, Cheshire. Vale of Todmorden; Newton; Oldham; Bootle, Lancashire.

Humber. Teesdale; Croukley Fell ; Hambledon Hills ; Halifax; Richmond Racecourse; pastures in Swaledale; Sheffield, etc., Yorkshire.

Trne. Near Shewing Shields; Hexham; Horsley;

Tynemouth; Newcastle Town Moor, Northumberland. Beamish, Durham.

Lakes. Keswick; Castle Sowerby; Daleton; Flimby ; 
Aspatria, Cumberland. Rigriceden, and elsewhere, Westmoreland.

West Lowlands. About Dumfries; Drumlanrig; Barhill; Inwold; Dumfriesshire. Dalseareth; Douglas Hall ; Colvend, Kircudbrightshire. Portpatrick, Wigtonshire. Ayrshire. Lanarkshire. Gourock, Renfrewshire.

East Low lands. Bernerside Hill ; Blackburnrigg Dean ; Coldingham Moor, Berwickshire. Pentland Hills and elsewhere, Edinburghshire. Linlithgowshire. West Highlands. Glen Crae, Argyleshire. Dumbartonshire. Rothesay, Bute. Breeze Hill, Skye.

East Highlands. Clackmannanshire. Kinross-shire. Fifeshire. Ben Lawers; Loch Tay; Blair Athol; Craig Challiach; Perthshire. Clova Mountains; Montrose; Arbroath, Forfarshire. Kincardineshire. Belhelvie Links; Corsehill, Aberdeenshire. Mortlock; Banffshire. Morayshire. Auldean, Nairnshire. North Highlands. Ross-shire. Wick, Caithness. Northern Isles. Orkney, Shetland. Ulster. Roughfort; Belfast; Altmore Glen; Black Mountain, Antrim. Benyvena Mountains, near Magelligan, Londonderry. Scrubs, Down.

Leinster. Suggelaw, Wicklow.

Munster. Clonmel, Cork.

Var. rutaceum. Sands of Barry, Montrose.

\section{CRYPTOGRAIMME CRISPA.}

Peninsula. Exmoor, Devonshire. Summonsleath, Somerset.

Severn. Titterstone Clee Hill, Shropshire. Malvern Hills, Worcestershire. 
South Wales. Glamorganshire. Cardiganshire.

North Wales. Cerig-y-Druidion, Denbighshire. Dolgelly; Cader Idris, Merionethshire. Braddin Hills, Montgomeryshire. Cwm Idwal ; Clogwyn-du-Yrarddu, Snowdon; Glyder-vawr; Mynidd-Maw ; Llanberis, Carnarvonshire.

Trent. Fairfield; Chinley Hills, Derbyshire.

Mersey. 'Tag's Ness, near Macclesfield, Cheshire. Lancaster; Cliviger, near Todmorden; Fo Edge, near Bury, Lancashire.

Humber. Settle; Saddleworth; Fountain's Fell; Halifax; Wensleydale; Cronkley Scar; Ingleborough, Yorkshire.

Trne. Falcon Clints and elsewhere in Teesdale, Durham. Cheviot, above Langley Ford; Crag Lake; Haltwistle, Northumberland.

Lakes. Ambleside; Casterton; Moreland; on most of the hills of Westmoreland, abundant. Borrowdale; Winlath; Keswick; Skiddaw; Helvellyn; Grassmere; Scawfell ; Martindale, Cumberland. Coniston, Lancashire.

West Lowlands. Dumfries; Jardine Hall; Georgetown; Queensbury Hill; Rae Hill; Morton Hills; Moffat Dale, Dumfriesshire. Candy Hills and Douglas Hall, Colvend; Carsethorn; Crappel, Kircudbrightshire. Cuff Hill and Beith, Ayrshire. Renfrewshire.

East Lowlands. Eildon Hills; Winchope, Roxburghshire. South bank of the Whiteadder, Berwickshire. East Highlands. Fifeshire. Ben Lawers; Killin; Glen Tilt; Blair Athol, Perthshire. Clova Mountains; Lidlaw Hills; Glen Isla, Forfarshire. Glen Callater; Castleton; Loch-na-garr, Aberdeenshire. 
Kingussie; stone walls near Dalwhinnie; mountains of Morayshire.

West Highlands. Ben Nevis; Gnarrow ; Ben Aulder, Western Inverness-shire. Argyleshire. Loch Lomond, Dumbartonshire. Ben-na-Caillich, Skye. Isle of Mull.

North Highlands. Ross-shire, Sutherlandshire. Western Isles. Roddal, Harris.

Ulster. Carrickfergus, Antrim. Sleive Bignian; Mourne Mountains, Down.

Leinster. Carlingford Mountain, Louth.

\section{CYSTOPTERIS ALPINA.}

Trent. Derbyshire.

Humber. Yorkshire.

\section{CYSTOPTERIS FRAGILIS.}

Peninsula. Exwich, near Exeter, Devonshire. Cheddar Cliffs; Hampton Cliffs, Bath, Somersetshire.

Channel. Dorsetshire. Box, Wiltshire. Tunbridge Wells, Sussex.

Severn. Compton Verney, Warwickshire. Bristol, Gloucestershire. Skirrid Vawr, near Abergavenny; Wyndeliff Woods, Monmouthshire. Breedon Hill, Bromsgrove, Worcestershire. Staffordshire. Whitcliff, near Ludlow, Shropshire.

South WALES. Radnorshire. Brecknockshire. Pontnedd-Vechn, Glamorganshire. Cardiganshire.

North Wales. Anglesea; Wrexham, Denbighshire. Castle Dinas, Flintshire. Barmouth, Merionethshire. 
Cwm Idwal ; Clogwyn-y-Garnedd; Penmaen Mawr, and elsewhere, Carnarvonshire.

Trent. Leicestershire. Oxton and Bulwell Churches; Worksop, Nottinghamshire. Fairfield; Dovedale; Matlock Baths; Castleton; Lover's Leap, near Buxton, Derbyshire.

Mersey. Rostherne Church, Cheshire. Lancashire. Humber. About Settle; Rivaulx Abbey, Helmsley; Egglestone Bridge, on the Greta; Dropping Well, Knaresborough ; Castle Howard Park, Halifax ; Aysgarth Bridge, and elsewhere in Wensleydale; very abundant in Swaledale and all the north of Yorkshire. Trne. Cauldron Snout and elsewhere in Teesdale, Durham. Morpeth, Northumberland.

Lakes. Cumberland. Westmoreland. North Lancashire. West Lowlands. Moffat Dale, Dumfriesshire. Calderwood, Lanarkshire.

East Lowlands. Coldstream, Berwickshire. Pentland Hill and elsewhere, Edinburghshire.

East Highlands. Banks of Loch Lomond, Stirlingshire. Castle Campbell, Clackmannanshire. Den of Belthayoch ; Glen Queich, in the Ochils ; Pass of Isla, Forfarshire. Kincardineshire coast. Aberdeenshire. Morayshire.

West Highlands. Ben Nevis, Inverness-shire.' Ducroon, Argyleshire. Dumbartonshire.

North Highlands. Coul, Ross-shire. Sutherlandshire. Morven, Caithness.

Northern Isles. Hoy, Orkney.

Western Isles. Langa, Harris.

Ulster. Rocks at Carrickfergus, Antrim. Black Mountain, Down.

Connaught. Leitrim. Connemara, Galway. Sligo, near the town. 
Munster. Brandon Hill; cliffs above Mangerton, Kerry.

Var. dentata. Cheddar Cliffs, Somersetshire. Box, Wilts. Tunbridge Wells, Sussex. Arbury Hall, Warwickshire. Abergavenny, Monmouthshire. Dowards on the Wye, Herefordshire. Glamorganshire. Anglesea; Llangollen; Wrexham, Denbighshire. Craig Breiddia, Montgomeryshire. Llanberis; Penmaen Mawr, Carnarvonshire Dovedale, Derbyshire, Cheshire. Lancashire. Settle; Swaledale, Yorkshire. Caldron Snout, Durham. Kendal, Westmoreland. Silverdale, Lancashire. Moffat, Dumfriesshire. Kingussie, Morayshire. Inverness-shire. Morven, Caithness. Orkney. Antrim.

Var. angustata. Downton, Herefordshire. Llanberis, Carnarvonshire. Matlock, Derbyshire. Wensleydale and Swaledale, Yorkshire. Pentland Hills.

Var. Dickieana. Aberdeenshire.

\section{CYSTOPTERIS MONTANA.}

North Wales.

East Highlands. Ben Lawers; Mhiel Onfillach Mountains; Breadalbane Mountains, Perthshire.

\section{EQUISETUM ARVENSE.}

Peninsula. Cornwall, Devonshire, Somersetshire.

Channel. Isle of Wight, Hampshire, Dorsetshire, Wiltshire, Sussex.

Thames. Hertfordshire, Middlesex, Kent, Surrey, Oxfordshire, Berkshire, Essex. 
Ouse. Suffolk, Norfolk, Cambridgeshire, Bedfordshire, Huntingdonshire, Northamptonshire.

Severn. Warwickshire, Gloucestershire, Herefordshire, Worcestershire, Staffordshire, Shropshire.

South Wales. Glamorganshire, Pembrokeshire, Carmarthenshire.

Norтн Wales. Anglesea, Denbighshire, Flintshire. Trent. Leicestershire, Rutland, Lincolnshire, Nottinghamshire, Derbyshire.

Mersey. Lancashire, Cheshire.

Humber. Yorkshire.

Tyne. Northumberland, Durham.

West Lowlands. Dumfriesshire, Kircudbrightshire, Lanarkshire.

East Lowlan ns. Berwickshire, Haddingtonshire, Roxburghshire, Edinburghshire, Linlithgowshire.

West Highlands. Argyleshire, Dumbartonshire, Isles of Bute, Islay, and Cantire.

EAST Highlands. Stirlingshire, Clackmannanshire, Kinross-shire, Fifeshire, Perthshire, Forfarshire, Kin. cardineshire, Aberdeenshire.

North Highlands. Ross-shire, Sutherlandshire, Caithness.

Northern Isles. Orkney, Shetland.

Western Isles. Roddall, Harris.

Channel Isles. Jersey.

\section{FQUISETUM HYEMALE.}

Thames. Wanborough, near Guildford, Surrey.

Ouse. St. Faith's, Newton; Arming Hall Wood, Norwich, Norfolk. Stretham Ferry, Gamlingay, Cam- 
bridgeshire. Potton Marshes; Ampthill Bogs, Bedfordshire.

Severn. Near Middleton, Warwickshire. Pencoyd, Herefordshire. Moseley Bog, Worcestershire. Staffordshire. Dell in the Clee Hills, Shropshire.

South Wales. Swansea, Glamorganshire.

North Wales. Wrexham, Denbighshire. Flintshire.

Trent. Grace Dieu Wood, Charnwood Forest, Leicestershire. Nettleworth Green, Mansfield; Kirklington, Nottinghamshire.

Mersey. Near Arden Hall ; Lally's Wood, near Over; Thurtaston, Cheshire. Mere Clough, near Manchester, Lancashire.

Humber. Halifax ; by the Derwent, near Castle Howard ; Goodland Dale, near Whitby; Harkness, near Scarborough; by the Skell, near Ripon; Coneysthorpe; Halton Woods, Wharfedale; Rigby Woods, near Pontefract, and elsewhere in Yorkshire.

Trne. Hawthorn Dene; Castle Eden Dene, Durham. Scotswood Dene; Mill Green; Halton Wood; Felton; Warkworth, Northumberland.

Lakes. Lowgelt Bridge, Cumberland. Westmoreland. West Lowlands. Barnbarrock; Colvend, Kircudbrightshire. Carre Lyn; Calderwood, Lanarkshire. East Lowlands. Rosslyn; Lasswade; Dalkeith, and elsewhere about Edinburgh. Lamberton Moor, Berwickshire.

East Highlands. Kenmore, Perthshire. Den of Airby, Forfarshire. Park, banks of the Dee, Kincardineshire. Pittendriech; Forres, Morayshire.

North Highlands. Ross-shire.

Ulster. Antrim, Tyrone.

Leinster. Powerscourt, Wicklow. Wood at Leislip Castle, and elsewhere about Dublin. 


\section{EQUISETUM LIMOSUM.}

Peninsula. Cornwall, Devonshire, Somersetshire.

Channel. Hampshire, Isle of Wight, Dorsetshire, Wiltshire, Sussex.

Thames. Middlesex, Kent, Surrey, Hertforshire, Ox fordshire, Essex.

Ouse. Suffolk, Norfolk, Cambridgeshire, Bedfordshire, Huntingdonshire, Northamptonshire.

Severn. Warwickshire, Gloucestershire, Herefordshire, Worcestershire, Staffordshire, Shropshire.

South Wales. Glamorganshire, Carmarthenshire.

North Wales. Anglesea, Denbighshire.

Trent. Leicestershire, Rutland, Lincolnshire, Derbyshire, Nottinghamshire.

Mersey. Cheshire, Lancashire.

Humber. Yorkshire.

Trne. Durham, Northumberland.

Lakes. Westmoreland, Cumberland.

West Lowlands. Dumfriesshire, Kircudbrightshire,

Renfrewshire, Lanarkshire.

East Lowlands. Berwickshire, Roxburghshire, Edinburghshire.

West Highlands. Dumbartonshire.

East Highlands. Clackmannanshire, Kinross-shire, Perthshire, Fifeshire, Forfarshire, Aberdeenshire, Morayshire.

North Highlands. Ross-shire, Caithness.

Northern Isles. Kirkwall, Orkney.

Western Isles. N. Uist, Harris, Lewis.

Common all over Ireland and in Jersey. 


\section{FQUISETUM PALUSTRE.}

Peninsula. Cornwall. Devonshire. Weston-superMare, Somersetshire.

Channel. Hants. Isle of Wight. Dorsetshire. Purton, Wilts. Sussex.

Thames. Hertford; Stortford; Hitchin, Hertfordshire. Middlesex. Stoke, Surrey. Stratford, Essex. Oxfordshire.

Severn. Hart's Hill and elsewhere, W'arwickshire. Gloucestershire. Herefordshire. Staffordshire. Shropshire.

South Wales. Glamorganshire, Carmarthenshire, Pembrokeshire.

North Wales. Anglesea, Denbighshire, Carnarvonshire.

Trent. Leicestershire, Rutland, Lincolnshire, Derbyshire, Nottinghamshire.

Mersey. Cheshire, Lancashire.

Humber. Everywhere in Yorkshire.

Lakes. Westmoreland.

West Lowlands. Dumfriesshire, Kircudbrightshire, Lanarkshire.

East Lowlands. Berwickshire, Roxburghshire, Linlithgowshire, Edinburghshire.

West Highlands. Inverness-shire, Argyleshire, Isles of Islay and Cantire.

East Highlands. Stirlingshire, Clackmannanshire, Kinross-shire, Fifeshire, Kincardineshire, Morayshire, Perthshire, Forfarshire, Aberdeenshire.

North Highlands. Caithness, Ross-shire.

Northern Isles. Orkney.

Western Isles. Roddal, Harris. 
Very abundant in Ireland.

Var. polystachion. Weston-super-mare, Somersetshire. Shanklin Chine, Isle of Wight. Spye Park, Purton, Wilts. Richmond Park, Surrey. Stratford, Essex. Hart's Hill, Warwickshire. Conway Sands, Carnarvonshire. Crosby, Lancashire. Breadalbane Mountains, Perthshire. Braemar, Aberdeenshire. Logan Canal, Giant's Causeway.

Var. nudum. Bream Sands, Somersetshire. Broadbank, Lancashire. Aldingham, Yorkshire. Sands of Barry, Forfarshire. Breadalbane Mountains, Perthshire.

\section{EQUISETUM SYLVATICUM.}

Peninsula. Devonshire, Somersetshire.

Channel. Parsonage Lynch, Newchurch; Apse Heath, Isle of Wight. Dorsetshire. Wilts. Sussex.

Thames. Wools, Hertfordshire. Great Gate, Middlesex. Kent. Surrey. Berks. Essex.

Ouse. Suffolk. Norfolk. Chesterton; Madingley Wood, Cambridgeshire. Bedfordshire. Northamptonshire.

Severn. Arbury, Moseley Bog, Warwickshire. Gloucestershire. Herefordshire. Worcestershire. Staffordshire. Benthal Edge, Shropshire.

South Wales. Devil's Bridge and elsewhere, Cardiganshire. Carmarthenshire. Glamorganshire. North Wales. Merionethshire. Denbighshire. Trent. Leicestershire. Rutland. Derbyshire. Apsley Wood, Nottinghamshire. Mersey. Cheshire, Lancashire. 
Humber. Huddersfield ; Castle Howard ; Settle; Richmond; Swaledale; Leeds; Scarborough, Yorkshire. Trne. Morpeth; Hexham, Northumberland. Durham.

Lakes. Ennerdale, Cumberland. Westmoreland.

West Lowlands. Dumfriesshire, Kircudbrightshire, Renfrewshire, Lanarkshire.

East Lowlands. Houndwood; Langridge Dean, Berwickshire. Rosslyn and other woods, Edinburghshire. Roxburghshire.

West Highlands. Inverness-shire. Loch Fin, Argyleshire.

East Highlands. Clackmannanshire. Kinross-shire. Breadalbane Mountains and elsewhere, Perthshire. Montrose, Forfarshire. Fifeshire. Kincardineshire. Aberdeenshire. Nairnshire. Morayshire.

North Highlands. Ross-shire, Sutherlandshire.

Northern Isles. Orkney, Shetland.

Western Isles. Roddal, Harris.

Ulster. Antrim, Londonderry, Donegal.

Connaught. Oughterard, Galway.

Leinster. Slagstown, Dublin County. Wicklow.

\section{EQUISETUM TELMATEIA.}

Peninsula. Cornwall, Devon, Somerset.

Channel. Hants. Luccomb Cliff, Isle of Wight. Dorsetshire. Wiltshire. Hastings, Sussex.

Thames. Hertfordshire. Middlesex. Kent. Norwood, Godalming, Surrey. Oxfordshire.

Ouse. Ipswich, Suffolk. Norfolk. Cambridgeshire. Bedfordshire. Northamptonshire. 
Severn. Warwickshire, Gloucestershire, Worcestershire, Staffordshire, Shropshire.

South Wales. Glamorganshire, Carmarthenshire, Pembrokeshire.

North Wales. Anglesea, Denbighshire, Bangor, Carnarvonshire.

Trent. Leicestershire, Derbyshire, Nottinghamshire.

Mersey. Cheshire, Lancashire.

Humber. Arnecliffe and elsewhere, Yorkshire.

Tyne. Hawthorne Dene, Durham. Morpeth, Northumberland.

Lakres. Cumberland, Westmoreland.

W Est LowLands. Renfrewshire, Lanarkshire.

EAst Lowlands. Berwickshire, Edinburghshire.

West Highlands. Campbelton, Argyleshire. Islay, Arran.

Very frequent in Ireland and in Jersey.

\section{EQUISETUM TRACHYODON.}

East Highlands. Den of Airly, Forfarshire. Banks of the Dee, Aberdeenshire.

Ulster. Colin Glen, Belfast; Calton Glen, Antrim. Ballyharrigan Glen, Londonderry.

\section{FQUISETUM UMBROSUM.}

Humber. Yorkshire.

Tyne. Wynch Bridge, Teesdale, Durham. Warkworth,

Northumberland.

LAKES. Westmoreland. 
West Lowlands. Bonnington Woods; Fin Glen, Lanarkshire.

East Lowlands. Banks of Esk below Auchindenny, Edinburghshire. Woodcock Dale, Linlithgowshire. East Highlands. Campsie Glen, Stirlingshire. Dollar,Clackmannanshire. Dumfermline, Fifeshire. Glent Tilt; Ballater, Ochils; Perthshire. Ravine of White Water, Clova; Den of Airly; Caulachan; by Caledonian Canal, Forfarshire. Aberdeenshire. Banffshire. Morayshire.

Ulster. Glens of Antrim.

\section{EQUISETUM VARIEGATUM.}

Peninsula. Sidmouth, Devon.

Mersey. New Brighton, Cheshire. Bootle Sands; Southport; Waterloo, Lancashire.

Humber. Aysgarth Force, Wensleydale, Yorkshire. Trne. Widdy Bank, Wynch Bridge; Middleton; Teesdale, Durham. Northumberland.

Lakes. Gilsland, Cumberland.

West Lowlands. Lanarkshire.

East Lowlands. Near North Berwick, Haddingtonshire.

East Highlands. Sands of Barry, Dundee, Forfarshire. Banks of the Dee, Kincardineshire.

North Highlands. Tain, Ross-shire.

Leinster. Portmarnock Sands, Royal Canal, both near Dublin. Wicklow.

Munster. Ditch at Mucruss, Killarney, Kerry. 


\section{GYMNOGRAMME IFPTOPHYLLA.}

Channel Islands. Jersey.

\section{HYMENOPHYLLUM TUNBRIDGENSE.}

Peninsula. Rough Tor, near Camelford; near Penryn; and Looe, Cornwall. Bickleigh Vale; Vixen Tor; Staple Tor; and Shaugh, Dartmoor, Devonshire. Shepton Mallet, Somersetshire.

Channel. Kent. Tunbridge Wells; Cockbush, near Chichester ; Ardingly, Handcross, Telgate Forest, Sussex.

South Wales. Melincourt Waterfall; Pont-neddVechn, Glamorganshire. Brecknockshire.

North Wales. Harlech; Dolgelly; Barmouth, Vale of Festiniog; Merionethshire:

Mersey. Near Croydonbrook; hills from Macclesfield to Buxton, Cheshire. Greenfield near Saddleworth, Vale of Todmorden, Lancashire.

Humber. Eskdale, near Whitby ; near Halifax, York. shire.

Lakes. Ennerdale, Cumberland. Westmoreland. Conistone, North Lancashire.

West Lowhands. Drumlanrig, Dumfriesshire. Banks of the Clyde, Lanarkshire.

East Lowlands. Peeblesshire.

West Highlands. Bullwood; Dunoon; Argyleshire.

Banks of Loch Lomond, Dumbartonshire. Isles of Bute and Arran.

Connaught. Connemara; Ballynahinch, Galway. Leinster. Dublin County. Powerscourt, Glencree, Wicklow. 
Munster. Clonmel, Glengariff, Bantry, Cork. Glencarn ; about the lakes of Killarney, and elsewhere in the county of Kerry.

\section{HYIMENOPHYLLUM WILSONI.}

Peninsula. Bodmin; Corn Brea, near Redruth; Rough Tor, near Camelford ; Granite Tor, Cornwall. West Lynn; Vixen's Tor ; Wistmann's Wood, and Shaugh Bridge, Dartmoor; Tynemouth; Bickleigh Wood, Devonshire.

Severn. Gradbitch, near Flash, Staffordshire. Treflach Wood, Shropshire.

South Wales. Mountains of Brecknockshire. Pont Brew, Devil's Bridge, Hafont, Cardiganshire. Carmarthenshire.

North Wales. Dolgelly; Rhaiadr-du, near Maentwrog; Rhaidr-y-Mawrdach; Festiniog, Merionethshire. Cwm Idwal, and throughout the Snowdon district; Rhaiadr Mawr, near Llanberis ; Carnarvonshire.

Mersey. Near Bury, Lancaster; Greenfield; Thevilly, near Burnley, Lancashire.

Humber. Tamer Clough, Rishworth; Hawl Gell, near Mickleton; Low Harrogate, Yorkshire.

Trne. Jurionside, Northumberland.

Lakes. Patterdale; Stockgill Force ; Langdale Pikes; Ambleside, Westmoreland. Keswick; Bow Fell; Scaw Fell; Borrowdale; Ennerdale; Scale Force, near Buttermere; Honister Craig, Cumberland. Near Conistone; Old Man Mountain; Silverdale, Lancashire. 
West Lowlands. Dalvene Pass; Nithside, near Pen. pont; Grey Mare's Tail, Moffat, Dumfriesshire. Kircudbrightshire. Glen Ness; Dalmellington, Ayrshire. East Lowlands. Peeblesshire.

West Highlands. Crenan; Glen Moray, Dunoon; Glen Fussiart, Argyleshire. Banks of Loch Lomond; Bowling Hills, Dumbartonshire. Ben More; Loch Spelire; Tabermorey, Isle of Mull. Isles of Islay and Arran.

East Highlands. By the Reeky Linn, on the Isla, Forfarshire. Dollar, Clackmannanshire. Glen Queich in the Ochils ; Ben Lawers ; Pass of Leny; Finlarig Burn, near Killin; Rocks in the Trosachs; shores of Loch Katrine, Perthshire.

North Highlands. Sutherlandshire.

North Isles. Hoy, Orkney. Near Ska, Unst, Shetland.

Western Isles. Langa, Harris.

Ulster. Near the Glenarve River, near Cleshandale; Colin-dell, Belfast, Antrim. Londonderry ; Ennishowen Mountains, Donegal. Tullaghmore Park; Mourne Mountains, Down. Florence Court, Fermanagh.

Connaught. Connemara; Oughterard, Galway. Mountains of Mayo.

Leinster. Dublin. Glendalough; Hermitage Glen; Powerscourt Waterfall, Wicklow.

Munster. Glens near Youghal, Cork. Great Blanket Island, Killarney. Mountains of Kerry. 


\section{ISOETES LACUSTRIS.}

South Wales. Lakes below Brecon Beacon, Brecknockshire. Glamorganshire.

North Wales. Lakes of Merionethshire. Denbighshire. Ogwen; Llyn-y-cwm; Lakes of Llanberis, Carnarvonshire.

Humber. Castle-Howard Lake; Foss reservoir, near Coxwold, Yorkshire.

Trne. Prestwick Carr, Northumberland.

LAK Es. Rydal and other lakes of Westmoreland. Ulleswater, Flontern Tarn, Buttermere, Crummack water, Derwentwater; Wastwater, Cumberland. Conistone, Lancashire.

East Highlands. Stirlingshire. Fifeshire. Loch Tay; Loch Lubnaig, Perthshire. Loch Brandy; Loch Whirrall, Forfarshire. Loch Callader, Aberdeenshire. West Highlands. Loch Sloy, Ben Voirlich, Dumbartonshire. Lakes in the Isles of Skye. Loch Fad, Bute.

North Highlands. Sutherlandshire.

Northern Isles. Kirkwall, Orkney.

Ulster. Lakes in the Rosses, Donegal. Castle Blaney Lake, Monaghan.

Connaught. Lakes of Connemara.

Leinster. Upper Lough, Bray; Glendalough, Wicklow.

\section{LYCOPODIUM ALPINUM.}

Peninsula. Hills of Somerset.

Channel. Hampshire.

South Wales. Brecon Beacon, Brecknockshire. Glamorganshire. Plinlymmon, Cardiganshire. 
Norte Wales. Flintshire. Denbighshire. Llanidloes; Montgomeryshire. Cader Idris, Merionethshire. Cwm Idwal ; Clyder Vawr ; Carnedd-David, Carnarvonshire.

Trent. Derbyshire.

Mersey. Micklehurst, Cheshire. Todmorden; Fo-edge; Mottram; Cliviger, Lancashire.

Humber. Ingleborough; Sowerby; Cronkley Fell; Swaledale; Scarborough, Yorkshire.

Trne. Falcon Clints and elsewhere in Teesdale, Durham. Cheviot, Northumberland.

LAKEs. Kirkston and other parts of Westmoreland. Great Gable; Ennerdale, and elsewhere in Cumberland. Conistone, Lancashire.

West Lowlands. Hills west of the Vale of Dumfries. Hills above Dalscairth, Kircudbrightshire. Renfrewshire. Lanarkshire.

East Lowlands. Roxburghshire. Lammermuirs; Lamberton Moor, Berwickshire. Pentland Hills, Edinburgh.

West Highlands. French Corrie, Strath Affarie; Ben Nevis, Inverness-shire. Ben Voirlich, Dumbartonshire. Ben Mare; Tobermorey, Isle of Mull; and other islands of the inner Hebrides.

North Highlands. Ross-shire. Ben Hope, Sutherlandshire. Morven, Caithness.

East Highlands. Clackmannanshire. Kinross-shire. Fifeshire. Ben Lawers; Blair Athol ; Killin, Perthshire. Sidlaw Hills; Glen Dale and Glen Phee, Clova, Forfarshire. Bay of Nigg, Kincardineshire. Invercauld, Aberdeenshire. Badenoch, Morayshire. Banffshire. Nairnshire.

Northern Isles. Hoy, Orkney. Unst, Shetland. 
Western Isles. Langa, Harris.

Ulster. Belfast Mountains, Antrim. Aghla; Barnesmoor; Muckish, Donegal. Mourne Mountains, Down.

Munster. Mangerton; Bandon, Kerry.

\section{LYCOPODIUM ANNOTINUM.}

North Wales. Glyder-Vawr, above Llyn-y-cwm, Carnarvonshire.

Trent. Charnwood Forest, Leicestershire.

Mersey. Rumworth Moss, Lancashire.

Lakes. Bowfell, Cumberland. Langdale, Westmoreland.

East Highlands. Mountains of Perthshire, Aberdeenshire, Morayshire, Banffshire; as Loch-na-garr, Munth Keane, Ben-na-Baird, and the Cairngorm Mountains. Glen Dale; Clova Mountains ; by Loch Esk, Forfarshire.

West Highlands. French Corrie, Strath Affarie, West Inverness-shire. Goat Fell, Arran, Isle of Mull. North Highlands. Freewater, Ross-shire. Northern Isles. Hoy Hill, Rackwick, Orkney.

\section{LYCOPODIUM CLAVATUM.}

Peninsula. Exmoor, Devonshire.'Brendon Hill and elsewhere, Somersetshire.

Channel. Hampshire. Dorsetshire. Wiltshire. Tilgate Forest, Sussex.

Thames. Tring, Hertfordshire. Hampstead, Middle- 
sex. Highdown Heath; Cæsar's Camp, Farnham; Woking Common; between Dorking and Leath Hill ; Addington Hills, Croydon.

Ouse. Norfolk. Gamlingay, Cambridgeshire. Bedfordshire.

Severn. Worcestershire. Staffordshire. Stiperstones; Shropshire.

South Wales. Glamorganshire. Plinlymmon, Cardiganshire.

North Wales. Cader Idris, Merionethshire. Den. bighshire. Snowdon, Carnarvonshire.

Trent. Charnwood Forest, Leicestershire. Nottinghamshire. Denbighshire.

Mersey. Todmorden; Simmons-wood Moss, Lancashire. Cheshire.

Humber. Frequent in the north and west of Yorkshire. Trne. Northumberland, Durham.

LAKes. Mountains of Cumberland. Langdale, Westmoreland.

West Lowlands. Dumfriesshire, Kircudbrightshire, Renfrewshire, Lanarkshire.

East Lownands. Peeblesshire. Roxburghshire. Pentland Hills, Edinburghshire. Berwickshire.

East Highlands. Clackmannanshire. Kinross-shire. Fifeshire. Clova Mountains, Forfarshire. Perthshire. Aberdeenshire. Mortlock, Banffshire. Badenoch, Morayshire.

West Highlands. Inverness-shire. Argyleshire. Dumbartonshire. Tobermorey, Isle of Mull.

North Highlands. Ben Wyvis, Ross-shire. Sutherlandshire. Morven, Caithness.

Northern Isles. Hoy; Rowsay, Orkney. Leinster. Kelly's Glen; Ballynascormy, Dublin County. 


\section{LYCOPODIUIM INUNDATUM.}

Peninsula. Cornwall. Bovey Heathfield, Devonshire. Somersetshire.

Channel. Titchfield; Christchurch; Selborne; St. Jermyn's and elsewhere in Hampshire. Poole, Dorsetshire. Wiltshire. Sussex.

Thames. Keston Heath; St. Paul's Cray ; Chiselhurst, Kent. Godalming; Witley; Bagshot; Chobham; Wimbledon; Esher, Surrey. Hampstead, Middlesex. Berkshire. Essex.

Ouse. Belton, Suffolk. South Wootton; Norwich; Filby; Yarmouth, Norfolk. Gamlingay, Cambridgeshire. Bedfordshire. Huntingdonshire.

Severn. Coleshill, Warwickshire. Hartlebury, Worcestershire. Staffordshire.

Trent. Leicestershire. Bogs by the Rainworth, Nottinghamshire. Derbyshire.

Mersey. Delamere Forest; Thurtaston; Bagueley Moor ; Bideton; Rudd Heath, Cheshire. Lancashire. Humber. Stockton Forest; sandpit, Malton Road, near York; near Racecourse, Richmond; Norland Moor, near Halifax, Yorkshire.

Lakes. Wastwater, Cumberland. Westmoreland.

East Highlands. Clunie Loch; Blair Athol, Perthshire. Ardarie Wood, Forfarshire. Cawdor Castle, Nairnshire. Fort St. George, Morayshire.

West Highlands. Inverarnon; between Luss and Inverglass, Dumbartonshire.

North Highlands. Craig Darrock, Ross-shire. Morven, Caithness.

Connaught. Connemara, Galway. 


\section{LYCOPODIUNI SFLAGINOIDES.}

North Wales. Aberfraw, Anglesea. Denbighshire. Cwm Idwal ; Clogwyn-ủu-Yrarddu ; Llanberis; Capel Curig, Carnarvonshire.

Trent. Kinder Scout, Derbyshire.

Mersey. New Brighton, Cheshire. Near Southport;

Seaforth Common; Bootle, Lancashire.

Humber. Cronkley Fell; banks of the Tees from Middleton to Caldron Snout; Settle; Richmond; York; Knaresborough ; Thirsk, Yorkshire.

Trne. Durham side of Tees Banks; Gateshead Fell,

Durham. Prestwick Carr, Northumberland.

Lakes. Loughrigg; Fairfield ; Kirkstone, Westmore-

land. Borrowdale; Keswick; Derwentwater; Scaw

Fell, Cumberland. Conistone, Lancashire.

West Lowlands. Grey Mare's 'Tail and elsewhere, Dumfriesshire. Dalscairth; Colvend, Kircudbrightshire.

East Lowlands. Lammermuirs; Lamberton Moor, Berwickshire. Banks of Tweed, Roxburghshire. Haddingtonshire. Edinburghshire.

West Highlands. Strath Affaria; French Corrie, Inverness-shire. Dunoon, Argyleshire. Dumbartonshire. Banks of Loch Sligachan, Isle of Skye; Isles of Islay and Cantire.

East Highlands. Stirlingshire. Clackmanuanshire. Kinross-shire. Fifeshire. Craig Challiach, Breadalbane Mountains, Perthshire. Canlochen; Glen Dole; Clova; Sidlaw Hills; Sands of Barrie, Dundee, Forfarshire. Glen Callater; Deanston, Aberdeenshire. Kingussie, Dalwhinnie, Morayshire.

North Highlands. Ross-shire, Sutherlandshire, Caithness. 
Northern Isles. Orkney, Shetland.

Western Isces. North Uist, Harris, Lewis.

Ulster. Belfast Mountains; near Larne, Antrim. Arrigal; Muckish ; and other hills of Donegal.

Connaught. Hills by the Killery; Leevane; Connemara, Galway.

Leinster. Carlingford Mountain; Louth. Dublin County.

\section{LYCOPODIUIM SELAGO.}

Peninsula. Cornwall. Sidmouth; Dartmoor, Devonshire. Somersetshire.

Channel. Aldershot, Hampshire. Dorsetshire. Wiltshire. Tilgate Forest, Sussex.

Thames. Highdown Heath ; Cæsar's Camp, Farnham, Surrey. Shotover Hill, Oxfordshire.

Ouse. Felthorpe Heath; Holt Heath; Norfolk. Severn. Worcestershire, Staffordshire, Shropshire. South Wales. Glamorganshire. Plinlymmon, Cardiganshire.

North Wales. Anglesea. Denbighshire. Cader Idris, Merionethshire. Llanberis; Cwm Idwal; Snowdon, Carnarvonshire.

Trent. Leicestershire. Rutland. Mansfield, Nottinghamshire. Edale Chapel, Derbyshire.

Mersey. Bidston, Cheshire. Woolston Moss, near Warrington; Todmorden, Lancashire.

Humber. Settle; Halifax; Ingleborough; Wensleydale; Swaledale; Cronkley Fell, Yorkshire.

Trne. Falcon Clints, Teesdale, Durham. Prestwick Carr; Haltwistle; Cheviot, Northumberland. 
Lak es. Skiddaw ; Ennerdale ; Helvellyn, Cumberland. Westmoreland.

West Lowlands. Lochan Moss, Dumfriesshire. Hills above Dalscairth and Neabie ; Creffel, Kircudbrightshire. Renfrewshire. Lanarkshire.

East Lowlands. Roxburghshire. Belford, Berwickshire. Pentland Hills, Edinburghshire.

West Highlands. Ben Nevis, Inverness-shire. Dunoon, Argyleshire. Goat Fell, Arran. Isles of Mull, Islay, Cantire, and Skye.

East Highlands. Clackmannanshire. Kinross-shire. Fifeshire. Perthshire. Glen Callater; Ben-namuich-Dhu, Aberdeenshire. Kincardineshire. Banffshire. Morayshire.

North Highlands. Sutherlandshire. Ross-shire. Caithness.

Northern Isces. Kirkwall, Hoy, Orkney.

Western Isles. North Uist, Harris, Lewis.

Ulster. Devis Mountain, Antrim. Arrigal; Muckish, Donegal. Slieve Donard, Down.

Ineinster. Dublin County.

Munster. Mangerton; Bandon; Carran Tual ; Killarney, Kerry.

\section{NEPHRODIUM CRISTATUM.}

Thames. Epping Forest, Essex.

Ouse. Westleton; Bexley Decoy, near Ipswich, Suffolk. Bawsey Heath, near Lynn; Dersingham; Edgefield, near Holt; Fritton, near Yarmouth; Surlingham, near Norwich; Wymondham, Norfolk. Huntingdonshire. 
Severn. Near Madeley, Staffordshire.

Trent. Oxton Bogs; Bulwell Marshes, Nottinghamshire.

Mersey. Wybunbury Bog, Cheshire. Woolston Moss, near Warrington, Lancashire.

Munster. Mucruss, Killarney, Kerry.

\section{NEPHRODIUM FIIIX-MAS.}

This fern in its normal form is present in every province of the British Isles. Only its varieties require to have their localities indicated.

Var. abbreviata. Ingleborough, Yorkshire. Conistone, Lancashire.

Var. incisa. Combe Martin, Devonshire. Wilts. Bridport, Dorsetshire. Sturry, Kent. Reigate; Virginia Water; Bagshot; Mayford; St. Martha's, Surrey. King's Cliffe, Northamptonshire. Cathcart Hills, Lanarkshire. Ben Chouzie, near Crieff, Perthshire. Kingcausie, Kincardineshire.

Var. Jervisii. Teesdale, from Cauldron Snout to the High Force, Durham and Yorkshire.

Var. pumila. Hilly moors in Durham and Yorkshire.

\section{NEPHRODIUM OREOPTERIS.}

Peninsula. Cornwall. Lynmouth and Ilfracombe, Devonshire. Somersetshire.

Channex. New Forest, near Lyndhurst; near Southampton, Hampshire. Isle of Wight. Dorsetshire. 
Wiltshire. Tilgate Forest; Tunbridge Wells and elsewhere, Sussex.

Thames. Bellwood, Bayford; Tring; Broxbourne, Hertfordshire. Hampstead, Middlesex. Bexley; Blackheath; Bailey's Hill, near Tunbridge, Kent. Witley; Hindhead; Cobham; Wimbledon, Surrey. Shotover Hill, Oxfordshire. Hartwell, Buckinghamshire. High Beech; Little Baddow, Essex.

Ouse. Bradwell, Suffolk. Crome, Norfolk. Fulbourne; Teversham, Cambridgeshire. Dallington Heath, Northamptonshire.

Severn. Allesley; about Arbury Hall; Coleshill Heath; Corley, Warwickshire. Forest of Dean, Gloucestershire. Herefordshire. Malvern Hills, Worcestershire. Staffordshire. Shropshire.

Soutu Wales. Radnorshire. Brecknockshire. Swansea, Glamorganshire. Carmarthenshire. Cardiganshire.

North Wales. Anglesea; Wrexham, Denbighshire. Flintshire, Dolgelly, Merionethshire. Llanberis and elsewhere in Carnarvonshire.

Trennt. Twycross, Leicestershire. Rutland. Lincolnshire. Oxton and Eddingley Bogs, Nottinghamshire. Dethick Moor; Riley, Derbyshire.

Mersey. Birkenhead; Oxton; Rudd Heath; Cheshire. Warrington; Rochdale; Rainhill; Gateacre; Lancashire.

Humber. Valley of the Don, Doncaster; Melton Wood, near Adwick; Escrick, near York; Whitby; Richmond; Wensleydale; Swaledale; Halifax; Scarborough, Yorkshire.

Trne. Chapel Weardale; Cawsey Dean, near Newcastle; Tees Banks; Durham. Northumberland. 
Lakes. Keswick; Patterdale, Cumberland. Langdale and elsewhere, Westmoreland.

East Lowlands. Ruberslaw; hills about Jedburgh, Roxburghshire. Pentland Hills, Edinburgh. Banks of Whiteadder, Berwickshire.

West Lowlands. Moffat Dale, Dumfriesshire. Lanarkshire.

East Highlands. Ben Lomond, Stirlingshire. Clackmannanshire. Kinross-shire. Glen Isla; Clova Mountains; Lidlaw Hills, Forfarshire. Craig Challiach; by Loch Tay; Trosachs, Perthshire. Aberdeenshire. Morayshire.

West Highlands. Argyleshire. Dumbartonshire. Isles of Arran, Islay, and Cantire.

North Highlands. Sutherlandshire.

Western Isles. North Uist.

Ulster. Milroy Bay, Donegal. Derry.

Connaught. Lough Corrib, Galway.

Leinster. Glencree ; Seven Churches ; Glendalough ;

Powerscourt, Wicklow.

Munster. Mangerton, Killarney, Kerry.

\section{NEPHRODIUM REIMOTUM.}

Banks of Windermere.

\section{NEPHRODIUM RIGIDUM.}

Humber. Ingleborough; Wharnside; Attermine Rocks, near Settle, Yorkshire.

Lakes. Arnside Knot; Hutton Roof-crags; Farlton 
Knot, Westmoreland. Silverdale; by the Lancaster and Kendal Canal, Lancashire.

\section{NEPHRODIUM SPINULOSUM.}

Peninsula. Cornwall, Devonshire, Somersetshire.

Channez. Hampshire, Isle of Wight, Dorsetshire, Sussex.

Thames. Hertfordshire. Kent. Middlesex. Surrey. Fulmer, Buckinghamshire. Epping; Danbury ; Coggeshall, Essex.

Ouse. Suffolk. Norfolk. Foulbourne; Cambridgeshire. Northamptonshire.

Severn. Warwickshire. Ankerberry Hill; Forest of Dean, Gloucestershire. Woods about Ross, Herefordshire. Worcestershire. Neadwood, Staffordshire. Sourn Wales. Brecknockshire, Glamorganshire, Carmarthenshire.

North Wales. Carnarvonshire.

Trent. Papplewick; Oxton Bogs, Nottinghamshire. Leicestershire. Derbyshire.

Mersey. Delamere Forest; Rosthern Mere, Cheshire. Chatmoss, Lowgill; Risley Moss, near Warrington, Lancashire.

Humber. Sheffield; Richmond; Ingleborough ; Swaledale; Doncaster; Lechby Carr; Terrington Carr, Yorkshire.

Lakes. Cumberland, Westmoreland, Isle of Man.

North Highlands. Ross-shire.

West Highlands. Argyleshire, Arran.

Western Isles. North Uist, Lewis.

Var. bipinnatum. Devonshire. Somersetshire. 
Hampshire. Dorsetshire. Sussex. Herts. Kent. Virginia Water and elsewhere in Surrey. Middlesex. Epping, Essex. Norfolk. Cambridgeshire. Northamptonshire. Many parts of Warwickshire. Gloucestershire. All round Ross; Colwall, Herefordshire. Staffordshire. Shropshire. Brecknockshire. Glamorganshire. Cardiganshire. Pembrokeshire. Denbighshire. Flintshire. Carnarvonshire. Leicestershire. Matlock, Derbyshire. Lincolnshire. Nottinghamshire. Mobberley and elsewhere, Cheshire. About Manchester. Lechby Carr; Hackfall; Sheffield Moor; Settle; Halifax ; Ingleborough, and elsewhere, Yorkshire. Morpeth, Northumberland. Durham. Westmoreland. Cumberland. Dumfriesshire. Ayrshire. Lanarkshire. Roxburghshire. Berwickshire: Edinburghshire. Stirlingshire. Clackmannanshire. Kinross-shire. Fifeshire. Perthshire. Forfarshire. Aberdeenshire. Banffshire. Morayshire. Inverness-shire. Argyleshire. Isles of Arran, Islay, and Cantire. Rossshire. Harris. Lewis. Clonmel, Cork. Jersey.

Var. dilatatum. As widely diffused as the nearly allied species bipinnatum.

Var. dumetorum. Matlock, Derbyshire. North Wales, Westmoreland. Edinburghshire.

Var. cemulum. Penzance; Helston; Lostwithiel; Truro; Looe, Cornwall. Chambercombe; Ilfracombe; Lynton; Barnstaple; Clovelly, Devonshire. Tunbridge Wells and elsewhere in Sussex. Various parts of Kent. Herefordshire. St. Bee's Head, Cumberland. Barmouth, Merionethshire. Baldanan, Kennedy, Forfarshire. Banks of Loch Lomond, Dumbartonshire. Rocks along the coast of Arran, from Corrie to Brodick, Arran. Hoy, Orknev. North 
Uist, Fairhead, Antrim. Near Coleraine. Rushbrook; Garnagh, Londonderry. Milroy Bay, Donegal. Sligo; Newport, Westport, and elsewhere in Mayo. Various parts of Galway. Seven Churches; Glendalough, Wicklow. Clare. Cork. Woods of Kerry.

\section{NEPHRODIUN THELYPTERIS.}

Peninsula. Devonshire, Somersetshire.

Channel. Portsea; Winchester, Hampshire. Isle of Wight. Tunbridge Wells; Albourne; Amberley; Waterdown Forest; Ore, near Hastings, Sussex.

Thames. North Cray; Bexley; Ham Ponds, near Sandwich, Kent. Leith Hill, near Godalming; Wimbledon Common; Pirbright Common, Surrey. Windsor Park and Sonning Hill wells, Berkshire. Epping, Essex.

Ouse. Belton; Bungay; Hipton; Bradwell Common, Suffolk. Horning, St. Faith's; Upton ; Filby ; Holt ; Edgefield, Felthorpe; Wroxham; Dereham; Lound near Yarmouth; the neighbourhood of Norwich, Norfolk. Wicken and Whittlesea Fens; Feversham Moors; Gamlingay, Cambridgeshire. Potton Marshes, Bedfordshire. Huntingdonshire.

Severn. Herefordshire, Staffordshire, Shropshire. South Wales. Skelly Bog; Cwmbola, Glamorganshire. North Wales. Llydiart Lake, Pentraeth; Beaumaris, Anglesea.

Trent. Oxton and Bullwell Bogs, Nottinghamshire. Merser. Newchurch Bog, Knutsford Moor; Over; Wyburnbury Bog; Harnicroft Wood, near Wernith, Cheshire. 
Humber. Potterie Carr; Askham Bog; Terrington

Carr; Buttereramba, near York; Haslington; Doncaster; Settle; Fens at Askern, Yorkshire.

Tyne. Learmouth Bogs, Northumberland.

Lakes. Keswick; Ulleswater; Glencoin, Cumberland. East Highlands. Rescobie; Restenet, Forfarshire.

Ulster. Portmore Park, Antrim. Portumna, Galway. Connaught. Near Lough Carra, Mayo.

Leinster. Marshes at Glencree, Wicklow.

Munster. Marsh near Mucruss, Killarney, Kerry.

\section{OPHIOGLOSSUM VULGATUM.}

Peninsula. Cornwall. Slateford; Barnstaple, Devonshire. Somersetshire.

Channel. Strathfieldsaye; Stoke; Wanston, Hants. Bembridge Down; Blackgang Chine; West Cowes, Isle of Wight. Box, Dorsetshire. Longleat; Kingston Downs; fields near Brixton; Deverill, Wiltshire. Framfield, Sussex.

Thames. Bury Woods; Hitchin; Elstree; Essenden, Hertfordshire. Hackney Marshes; Sion Lane, Isleworth. Brentford; Middlesex. West Farleigh; Greenhithe and elsewhere, Kent. Compton; Beddington; Cobham ; Dorking, and in many other places, Surrey. Banbury and elsewhere, Oxfordshire: Kent. Ouse. Suffolk. Upton Broad, Ellingham Fen, Norfolk. Wilburton; Grantchester; Whitwell, Cambridgeshire. Bedfordshire. Huntingdonshire.

Severn. Foleshill; Wellesbourne, Warwickshire. Gloucestershire. Howle Hill, Ross. West Hopehill ; 
Upton Bishop, Herefordshire. Needwood, Staffordshire. West Felton, Shropshire.

North Wales. Anglesea. Wrexham, Denbighshire. Trent. Near Braunston; Thuringston; Humberstone, Leicestershire. Papplewick; Colwick, Nottinghamshire. Heaver; Breadsall, Derbyshire.

Mersey. Alderley, Cheshire. Warrington; Bidston Marsh, Lancashire.

Humber. Richmond; Swaledale; Settle; Whitby; Huddersfield, Yorkshire.

Trne. Middleton, Durham. Hexham; Hawthorn Dene,

Haltwhistle, Northumberland.

Lakes. Westmoreland, Cumberland.

West Lowlands. Kircudbrightshire, Lanarkshire.

East Lowlands. Coldstream, Berwickshire. Dalmeny and Arniston Woods, Edinburgh. Linlithgowshire.

West Highlands. Argyleshire.

EAst Highlands. Dunfermline, Fifeshire. Dunsinane, Perthshire. Forfarshire. Burghead, Morayshire.

Northern Isles. Orkney, Shetland.

Ulster. Knockagh; Carrickfergus; near Belfast, Antrim.

Connaught. Arran Isles, Galway.

Leinster. Holly Park, Dublin; Densinsh, Dublin.

Munster. Clonmel, Cork.

Var. angustifolium. Jersey.

OSMUNDA RFGALIS.

Peninsula. Marazion Marsh and elsewhere, Cornwall. Dawlish; Watermouth, near Ilfracombe; Holme 
Chase, near Ashburton, Devonshire. Many parts of Somersetshire.

Channex. West Hampshire. Isle of Wight. Purbeck,

Dorsetshire. Wiltshire. Tunbridge ; Uckfield, Sussex. Thames. Thursley; Hindhead; Hambledon Heath; Cæsar's Camp, Farnham; Chobham; Bagshot; Esher; Wimbledon; Dorking; Reigate, Surrey. Berkshire. Buckinghamshire. Great Warley and Little Warley; Little Baddow; Epping, Essex.

Ouse. Suffolk. Caistor, near Yarmouth; Horning Ferry, Bedfordshire.

Severn. Arbury; about Birmingham, Warwickshire.

Worcestershire. Staffordshire. Ellesmere Lakes. West Felton, Shropshire.

South Wales. Swansea, Glamorganshire. Fishguard, Pembrokeshire. Carmarthenshire.

North Wales. Anglesea. Denbighshire. Barmouth; near Festiniog, Merionethshire. Laughton Bog, Flintshire. Carnarvonshire.

Trent. Leicestershire. Mansfield; Bulwell, Nottinghamshire.

Mersey. Lindon Moss, near Mobberley, Cheshire. Speke, near Liverpool ; Chat Moss; Woolstone Moss, and elsewhere near Warrington; Poulton-le-Sand, Lancashire.

Humber. Pottery Carr, near Doncaster; Leeds ; Askham Bog; Whitby, York, and other parts of Yorkshire.

Trne. Durham, Northumberland.

Lakes. Windermere; Colwith, Westmoreland. Cumberland. Isle of Man.

West Lowlands. White Loch, Colvend, Kircudbrightshire. By the Clyde, Lanarkshire. 
East Highlands. Stirlingshire. Fifeshire. Kincardineshire. Culross, Perthshire. Arbroath; Montrose; Kinnaird, Forfarshire. Mill of Leys and elsewhere, Aberdeenshire.

West Highlands. Glen Finnart; Dunoon; Loch Fine, Argyleshire. By Loch Lomond, Dumbartonshire. Isle of Arran. Kyles of Bute. Isles of Mull and Islay.

North Highlands. Inchnedaruff, Sutherlandshire. Ross-shire.

Northern Isles. Shetland.

Western Isles. North Uist, Harris, Lewis.

Connaught. Connemara; Oughterard, Galway. Achill Island. Castlebar, Mayo.

Leinster. Kelly's Glen, Dublin.

Munster. Bandon; Clonmel, Cork. Letterfrock, near Ballinaskellig's Bay; Mucruss Abbey, Killarney, Kerry.

Channel Isles. Jersey.

\section{PILULARIA GLOBULIFERA.}

Peninsula. Roche; Marazion Marsh, Cornwall. Blackdown ; Polwhele, Devonshire. Maidendown, Somersetshire.

Channel. Lymington; Holt Forest; Southampton; Badderley, Hampshire. Pool; Sandford Bridge, Dorsetshire. Warminster, Wiltshire. Pittdown; Churley North; Quaybrook; Chiltington, Sussex. Thames. Northaw, Hertfordshire. Hounslow Heath; Hillingdon, Middlesex. Esher Common, Reigate. Walton-on-the-hill; Henley Park, Pirbright; Roehampton, Surrey. 
Ouse. Hopton, Suffolk. Filby ; St. Faith's, Newton ; Yarmouth, Norfolk. Hinton Bog, Cambridgeshire. Fen near Peterborough, Northamptonshire.

Severn. Coleshill Pool, Warwickshire. Staffordshire. Bomare Pool, Shropshire.

South Wales. Rhos Gach, near Llandegly, Radnorshire. Mountain Pool, near Pont-nedd-Vechn, Glamorganshire. St. David's Head, Pembrokeshire.

North Wales. Near Llanfaelog, Anglesea. Llyn Idwal; Llanberis Lake, Carnarvonshire.

Trent. Leicestershire.

Mersey. Bagueley Moor; Beam Heath, near Nantwich; Barlington Heath; Woove, Cheshire. Allerton, Lancashire.

Humber. Near Richmond; Stockton Forest; Gormire Pool and Lechby Carr; Thirsk; Terrington Carr, Yorkshire.

Trne. Near Woolsingham; Prestwick Carr; Ponteland, Northumberland.

West Lowlands. Dumfriesshire. Kircudbrightshire. Rotherglen, Lanarkshire.

East Low lands. Pentland Hills; Braid-hill Marshes, Edinburghshire.

West Highlands. Loch Lomond and elsewhere in Dumbartonshire.

East Highlands. Perthshire. Slateford; Monroman Moor ; Alyth ; Forfar, and other parts of Forfarshire. Loch of Drum, Kincardineshire. Morayshire.

North Highlands. Sutherlandshire.

Ulster. By the Blackwater, near Lough Neagh; by the Bann, below Jackson's Hall, Coleraine, Antrim.

Connaught. Ballinahynch, Galway. 


\section{POLYPODIUM ALPESTRE.}

East Highlands. Mountains near Dalwhinnie, Inverness-shire. Caulochen Glen, Forfarshire.

West Highlands. Great Corrie of Ben Aulder, Inverness-shire.

\section{POLYPODIUM DRYOPTERIS.}

Peninsula. Mendip Hills; about Clevedon and Yattan; near Bristol; near Bath, Somersetshire.

Thames. Cornbury Quarry, Oxfordshire.

Severn. Berkswell, Warwickshire. Forest of Dean, Gloucestershire. Tintern Abbey, Monmouthshire. Penyard Park, near Ross; Downton Castle; Aymestry Quarry; Shobden Hills, Herefordshire. Shrawly Wood, Worcestershire. Trentham Part; near Cotton Hall and Oakamoor; Needwood, Staffordshire. Titterstone Clee Hills; Whitecliffe, near Ludlow ; Frod• desley Hill, Shropshire.

South Wales. Craig-Pwll-du, Radnorshire. Brecon; Trecastle ; Pont Henryd, near Capel Colboen; Ystred Felltree, Brecknockshire. Pont-nedd-Vechn; Scwdy-Gladis; Merthyr Tydvil, Glamorganshire. Ponterwyd; Hafod, Cardiganshire.

North Wales. Anglesa. Llangollen, Denbighshire. Craig-Breidden; Plinlymmon, Montgomeryshire. Merionethshire. St. Asaph, Flintshire. Cwm Idwal ; Llanberis ; Bangor ; Rhaiadr--y-Wenol ; Twll-du, Carnarvonshire.

Trent. Chinley Hill, near Chapel-le-Frith; Pleasley Forges, Derbyshire. Lincolnshire. Mersey. Hill Cliff, Cheshire. Warrington; Broad- 
bank; Deanchurch Clough; Mere Clough; Cotteril Clough; Lancaster; Ashworth Wood, Lancashire. Humber. Burley; Brimhan Rocks; Hackfall; Thirsk ; Ingleborough; Rivaulx Wood; Teesdale; Halifax; Whitby; Richmond; Wensleydale; Swaledale; Settle; Brierley; Castle Howard Park ; and many other parts of Yorkshire.

Trne. Walbottle Dene, foot of the Cheviot, Durham. Morpeth; Hexham; Shewing Shields; Scotswood Dene, Northumberland.

LaKes. Lodore, near Keswick; Borrowdale; Calder Bridge; Wasdale; Scale Force; Gillsland ; Cumberland. Ambleside; Hutton Roof; Casterton, Westmoreland. Conistone, Lancashire.

West Lowlands. Drumlanrig; Maiden-bower Crags, Dumfriesshire. Cludea Craigs ; hills above Dalscairth, Kircudbrightshire. Falls of the Clyde; Calderwood, Lanarkshire. Gourock, Renfrewshire.

East Lowlands. Wanehope, Roxburghshire. Banks of the Whiteadder; Longformeans; Berwickshire. Rosslyn and Auchindenny Woods, Edinburghshire.

East Highlands. Clackmannanshire. Kinross-shire. Carden Den, Fifeshire. Culross; Ben Lawers ; Killin; Dalnacardoch; Killicrankie ; Perthshire. Sidlaw Hills; Clova Mountains; Clack of the Ballock, Forfarshire. Inglies Maldie, Kincardineshire. Braemar, Aberdeenshire. Cawdor woods, Nairnshire. Dalwhinnie, Morayshire.

West Highlands. French Corrie, Strath Affarie, Inverness-shire. By Loch Lomond; Ben Voirlich; between Lochs Awe and Etine; Brodick; various parts of Bute; Arran. Tobermory, Isle of Mull. Nortir Highlands. Ross-shire, Sutherlandshire. 
Ulster. Knockleyd, Antrim. Mourne Mountains, Down.

Connaught. Main Turk, Galway.

Munster. Mucruss, Killarney, Kerry。 .

\section{POLYPODIUM PHEGOPTERIS.}

Peninsula. Near Tintagel, Cornwall. Sheep's Tor;

Dartmoor; Ilfracombe; Beeky Falls, Devonshire.

Channel. Forest Row, Sussex.

Thames. Windsor environs, Berks.

Severn. Forest of Dean; near Lydbrook, Gloucestershire. Shobden-hill Woods; Aymestry Quarry, Herefordshire. Ridge Hill ; Madeley, Staffordshire. Titterstone Clee Hill; near Ludlow, Shropshire. South Wales. Craig-Pwll-du; Rhayader, Radnorshire. Pont Henryd, near Capel Colboen; Brecon Beacon, Brecknockshire. Pont-Nedd-Vechn; Scwdy-Gladis; Cilhepste, Glamorganshire. Glynhir, near Llandebie, Carmarthenshire. Hafod and other localities, Cardiganshire.

North Wales. Plinlymmon, Montgomeryshire.

Waterfalls near Festiniog; Barmouth, Merionethshire. Llanrwst, Denbighshire. Cwm Idwal ; Llanberis ; Aberglaslyn; Bangor, Carnarvoushire.

Trent. Buxton, Derbyshire.

Mersey. Werneth; Holmes Chapel, and elsewhere, Cheshire. Deanchurch Clough, near Bolton. Prestwich Clough, near Manchester; near Todmorden; Blackhay; Clitheroe, Lancashire.

Humber. Halifax; Beckdale, Helmsley; Buttercrambe Moor, near York; Settle; Sheffield; Ingleborough ; 
Richmond; Swaledale, and many other parts of Yorkshire.

Trne. Banks of the Tees above Middleton; Langley Ford; Cawsey Dene, Durham. Moors near Wallington; Shewing Shields; Cheviot Hills; Hexham, Northumberland.

LAKes. Wardale; Borrowdale; Ennerdale; Scawfell; Keswick; Tindall Fell, Cumberland. Ambleside; Casterton Fell ; Grassmere ; Hutton Roof, Westmoreland. Conistone, Lancashire. Isle of Man.

West Lowlands. Drumlanrig; Rae Hills; Jardine Hill, Dumfriesshire. Dalscairth; Mabie, Kircudbrightshire. Gourock, Renfrewshire. Falls of the Clyde; Calderwood; Crutherland; Campsie, near Glasgow, Lanarkshire.

East Lowlands. Berwickshire. Jedburgh; Ruberslaw; Kelso, Roxburghshire. Arniston; Rosslyn; Auchindenny Woods, Edinburgh.

East Highlands. Castle Campbell, near Dollar, Clackmannanshire. Dunfermline; Inverkeithing; Carden Den, Fifeshire. Kincardineshire. Glen Queich in the Ochils; Ben Lawers; Dalnacardoch ; Tyndrum; Killin; Bridge of Brackland, near Callander; Craig Chailliach, Loch Tay, Perthshire. Canlochen; Clova, Forfarshire. Castleton; Braemar, Aberdeenshire. Dalwhinnie, Morayshire.

West Highrands. Aberarder; Ben Nevis; Red Caird Hill, Inverness-shire. Dunoon; Crinnan; Inverary; Pass of Glencrae; Kyles of Bute, Argyleshire. Ben Voirlich; by Loch Lomond; Tarbet; Arroquher, Dumbartonshire. Isles of Bute, Mull, Islay, and Cantire.

North Highlands. Kessock, Ross-shire. Loch Erbott, Sutherlandshire. Morven, Caithness. 
Northern Isles. Hoy; Orkney; North Marm; She乞́land.

Ulstær. By the Glenarve, near Cushendall, and other parts of Antrim. Waterfall above Lough Esk, Donegal. Slieve Bignian; near Slieve Croob; Black Mountain, Down. Ness Glen, Londonderry.

Leinster. Carlingford Mountain; South Powerscourt Waterfall, Wicklow.

Munstwr. Between Killarney and Kenmare; Mucruss, Kerry.

\section{POLYPODIUM ROBERTIANUM.}

Peninsula. Bath; Cheddar cliffs; Mendip Hills; about Clevedon and Yatton; Hinton Abbey, Somersetshire.

Channel. Box Quarries; Corsham, Wilts.

THAMES. Oxfordshire.

Severn. Besborough Common; banks of the Wye, near Whitchurch; Forest of Dean; Windlass, near Cheltenham; Cleamcloud; Cotswold Hills ; Cirencester; Leigh Wood, near Bristol, Gloucestershire. Worcestershire. Staffordshire.

Soutr Wales. Merthyr Tydvil, Glamorganshire.

Norte Wales. Llanferras, Denbighshire.

Mersey. Lancaster; Barnley; Broadbank, Lancashire. Trent. Matlock; Buxton; Bakewell, Derbyshire. Humber. Ingleborough; near Settle; Auster Rocks; Arnecliffe; Gordale; Ravenscar; Waldenhead; Swaledale, Yorkshire.

Trne. Falcon Clints, Durham. 
Lakes. Newbiggin Wood; Gelt Quarries; Baron Heath, Cumberland. Scout, near Kendal; Arnside Kust; Hutton Roof; Farleton Knot; Caskill Kirk, Westmoreland.

\section{POLYPODIUII VULGARE.}

As widely diffused as Nephrodium Filix-mas, and, like it, present in abundance in all the provinces; the varieties are rarely found.

Var. Cambricum. Torquay, Devonshire. Cheddar Cliffs, Somersetshire. North Wales. Braid Hill, Edinburgh. Arran Isles. Wicklow. Killarney. Guernsey.

Var. bifidum. Monmouthshire, Yorkshire.

Var. bifido-lobatum. Somersetshire.

Var. coriaceo-bifidum. Malton, Yorkshire.

Var. crenatum. Wales and Ireland.

\section{PTERIS AQUILINA.}

Even more common than the Polypody, present in every province like it, and flourishing alike in wood and on plain, in valley and on hills, up to the height of 16,000 feet.

\section{SCOLOPENDRIUM VULGARE.}

Peninsula. Cornwall. Devonshire. Many parts of Somersetshire.

Channel. Fareham and elsewhere in Hampshire. Isle of Wight. Sussex. Dorsetshire. Wiltshire. 
Thames. Hertfordshire, Middlesex, Kent, Surrey, Berkshire, Buckinghamshire, Oxfordshire, Essex.

Ouse. Suffolk, Norfolk, Cambridgeshire, Bedfordshire, Huntingdonshire, Northamptonshire.

Severn. Warwickshire, Gloucestershire, Worcestershire, Herefordshire, Staffordshire, Shropshire. Soutr Wales. Brecknockshire, Pembrokeshire, Glamorganshire, Carmarthenshire.

North Wales. Anglesea, Denbighshire, Carnarvonshire.

Trent. Leicestershire, Nottinghamshire, Derbyshire. Mersey. Cheshire, Lancashire.

Humber. Yorkshire.

Trne. Durham, Northumberland.

LaKes. Cumberland, Westmoreland, Isle of Man.

West Lowlands. Dumfriesshire, Kircudbrightshire, Wigtonshire, Ayrshire, Renfrewshire, Lanarkshire.

East Lowlands. Roxburghshire, Edinburghshire, Berwickshire.

West Highlands. Argyleshire. Isles of Bute, Islay, Cantire, and Skye.

East Highlands. Fifeshire, Morayshire, Forfarshire, Kincardineshire, Aberdeenshire, Nairnshire.

North Highlands. Sutherlandshire.

Northern Isles. Isles of Rowsay, Orkney, Shetland. Connaught. Galway, Arran Isles, Sligo.

Leinster. Dublin.

Munster. Cork, Kerry.

Channel Isles. Jersey.

Var. polyschides. Nettlecombe, Somersetshire, Fareham, Hampshire.

Var. multifidum. Swaledale, Yorkshire.

Var. undulatum. Fareham, Hampshire. Yorkshire. 


\section{TRICHOMANHS RADICANS.}

Leinster. Hermitage Glen; Powerscourt Waterfall, Wicklow.

Munster. Glendine Wood and Glenbour, Killeagh, near Youghal; Temple Michael Glen and Ballinhasy Glen, near Cork. Turk Waterfall, Killarney; ravine of Cromaglann Mountain; Mount Eagle, near Dingle; Gortagaree; Blackstones in Glen Caragh; Inveragh; Curraan Lake, Waterville, Kerry.

Connaught. Arran Isles.

\section{WOODSIA HYPERBORIA.}

North Wales. Clogwyn-y-Garnedd, Snowdon, Carnarvonshire.

East Highlands. Ben Chouzie, near Crieff; Catzaghiamman, Ben Lawers. Mael-dun-Crock ; Craig Challiach, Perthshire. Glen Isla, Glen Phee, Clova Mountains, Forfarshire.

\section{WOODSIA IIVENSIS.}

North Wales. Clogwynn-y-Garnedd; Llyn-y-cwm, on Glyder Vawr, Carnarvonshire.

Trye. Falcon Clints? and Caldron Snout?, Teesdale, Durham.

West Lowlands. Devil's Beef-tub, and hills north of Moffat; hills dividing Dumfries and Peeblesshire.

East Highlands. Ben Chouzie, near Crieff, Perthshire. Glen Phee, Clova Mountains, Forfarshire. 


\section{IN DEX.}

Acrogens, 4.

Acrostichum (stove), 56. uses of, 74.

Adder's-tongue, 189.

Adiantum, British, 180.

- half-hardy, 36.

- hardy, 25. stove, 57.

Alsophila, stove, 61 .

Annulatæ, 94.

Aspidium, British, 126.

- half-hardy, 33. hardy, 22.

Asplenium, British, 155.

- half-hardy, 38 . hardy, 23. stove, 62.

Bladder-fern, 150.

Blechnum, British, 179.

- half-hardy, 35.

- hardy, 24 . stove, 56 .

Botrychium, 191.

Bristle-fern, British, 183. stove, 71 .

Building of fernery, 19.

Cassebiera, half-hardy, 37.

stove, 61 .

Caudex, 7.

Ceratopteris, stove, 70 .

Cheilanthes, half-hardy, 37. stove, 59.

Chinese fern-oil, 80.

Cibotium, stove, 69.

Classification, 94.

- Newman's, 107.

Club-moss, 194.
Common Brake, 174.

Compost for hothouses, 46 . for potting, 31 .

for open-air ferneries, 19 .

Cormophyllaceæ, 107.

Cryptogams, 4.

Cryptogramme, 178.

Cultivation in greenhouse, 28 .

- in hothouses, 45 .

- in the open air, 19. in Wardian cases, 28.

Cyathea, half-hardy, 43.

stove, 69.

Cystopteris, British, 150.

- hardy, 24.

Diplazium, stove, 67 .

Diseases of ferns, 73.

Distribution of Fern family, 90.

- local, 217.

Doodia, stove, 65 .

Dorsal fructification, 12.

Drynaria, half-hardy, 32.

Dutch rushes, 212.

Dyes extracted from Lycopods, 85.

Edible ferns, 74 .

- Horsetails, 86.

Elaphoglossum, stove, 54 .

Elk's-horn ferm, 55.

Endogens, 4.

Equisetacer, 204.

Equisetum, edible, 86.

Exannulatæ, 94.

Exogens, 3.

Fadyenia, stove, 68.

Fern-case, ornamental, 30. Wardian, 29. 
Fern, flowering, 186.

Fern house, 45.

Fern, parts of, 6 .

Fern oil, 69.

Ferneries, 20.

Fernery, construction of, 19 .

Ferns, edible, 74 .

- gold, 49 .

- silver, 49.

Filix-mas, uses of, 75 .

Flowering-fern, 186.

Foreign ferns, half-hardy, 32.

- hardy, 21.

Fronds, 8.

Fructification, 11.

Fungus, parasitic, 73.

Genera, table of, 95.

Germination from spores, 15. viviparous, 17.

Gleichenia, half-hardy, 40.

Gold ferns, 49.

Goniophlebium, stove, 54 .

Grubs, 72.

Gymnogramme, British, 109.

- stove, 49 .

Half-hardy ferns, 32.

Hardy ferns, 21.

Hard-fern, 179.

Hart's-tongue, 173.

Herbarium, 87.

Horsetails, 204.

Hymenophyllum, 184.

Index, 279.

Indusium, 12.

Introduction, 1.

Involucre, 12.

Isoetes, 202.

Lady-fern, uses of, 78.

Lamb, Scythian, 82.

Lamb, vegetable, 83.

Local distribution of ferns, 217.

Lycopodiaceæ, 193.

Lycopodium, tincture of, 84 .

Lycopods, uses of, 84.

Lygodium, stove, 70.

Maiden-hair, British, 180.
Maiden-hair, half-hardy, 36.

- hardy, 25.

- stove, 57 .

- uses of, 81.

Male-fern, uses of, 76 .

Marginal fructification, 12.

Meriscium, 66.

Method of preservation for herbarium, 87.

Moonwort, 191.

Nephrodium, British, 134.

hardy, 23.

Nephrolepis, stove, 67.

Newman's classification, 107.

Niphobolus, 39.

Nothochlæna, stove, 64 .

— half-hardy, 39.

Onoclea, 26.

Onychium, 38.

Ophioglossum, 189.

Ornamental fern-cases, 30.

Osmunda, British, 186.

— hardy, 27.

Parts of a fern, 6 .

Pillwort, 203.

Pilularia, 203.

Pinnæ, 10.

Pinnules, 10.

Platycerium, stove, 55.

Platyloma, half-hardy, 42.

- stove, 64 .

Polybotrya, stove, 48.

Polypodium, British, 111.

- hardy, 21.

- stove, 51.

Polystichum, British, 126.

Potting, 31.

Preservation for herbarium, 87.

Propagation, 15.

Provinces of ferns, 217.

Pteris, British, 174.

— stove, 65.

— edible, 79 .

- half-hardy, 42.

Pula, 81.

Quillwort, 201. 
Rachis, 8.

Rlizophyllaceæ, 107.

Roots, 6.

Royal fern, 186.

Scalariform tissue, 9.

Scale, 32.

Scales, 8.

Scolopendrium, British, 173. hardy, 24.

Scythian-lamb fern, 82.

Seedlings, 16.

Snails, 73 .

Species, table of, 97 .

Spores, 13.

Stem, 8.

Stenochlæna, 55.

Stove ferns, 45.

Structure of ferns, 6 .

Struthiopteris, hardy, 22.
Table of genera, 95.

— species, 97.

Thrips, 32.

Tincture of Lycopodium, 84.

Todea, 44.

Treatment for insect, etc., 32 .

Trichomanes, British, 183.

- stove, 71.

Uses of ferns, 74 .

Vegetable lamb, 82.

Vernation, 8.

Viviparous production, $1 \%$.

Wardian cases, 29.

Wolf's-claw, 194.

Woodsia, British, 123. hardy, 22.

Woodwardia, half-hardy, 38. hardy, 25. 

PLATES. 



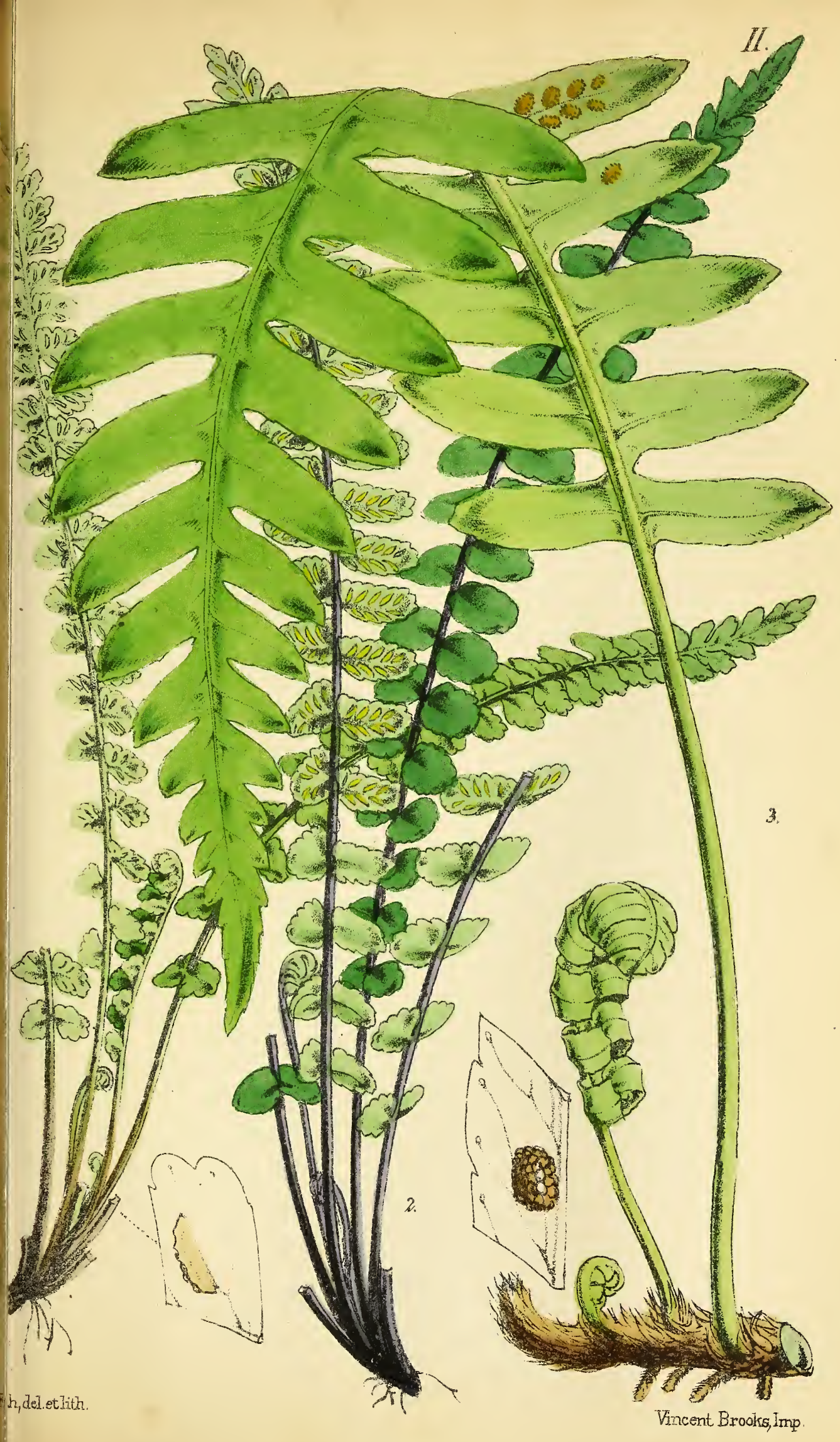



III.

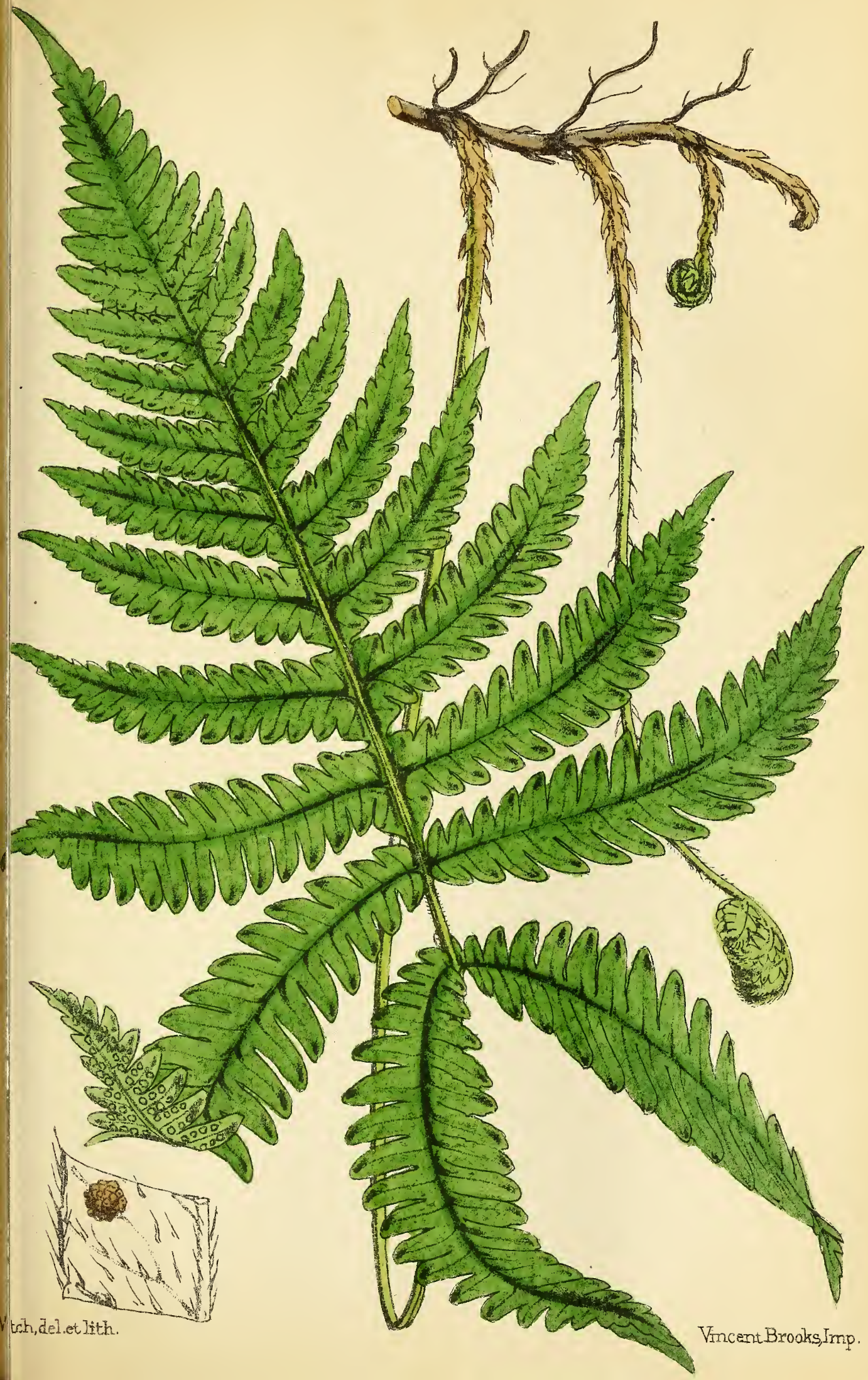





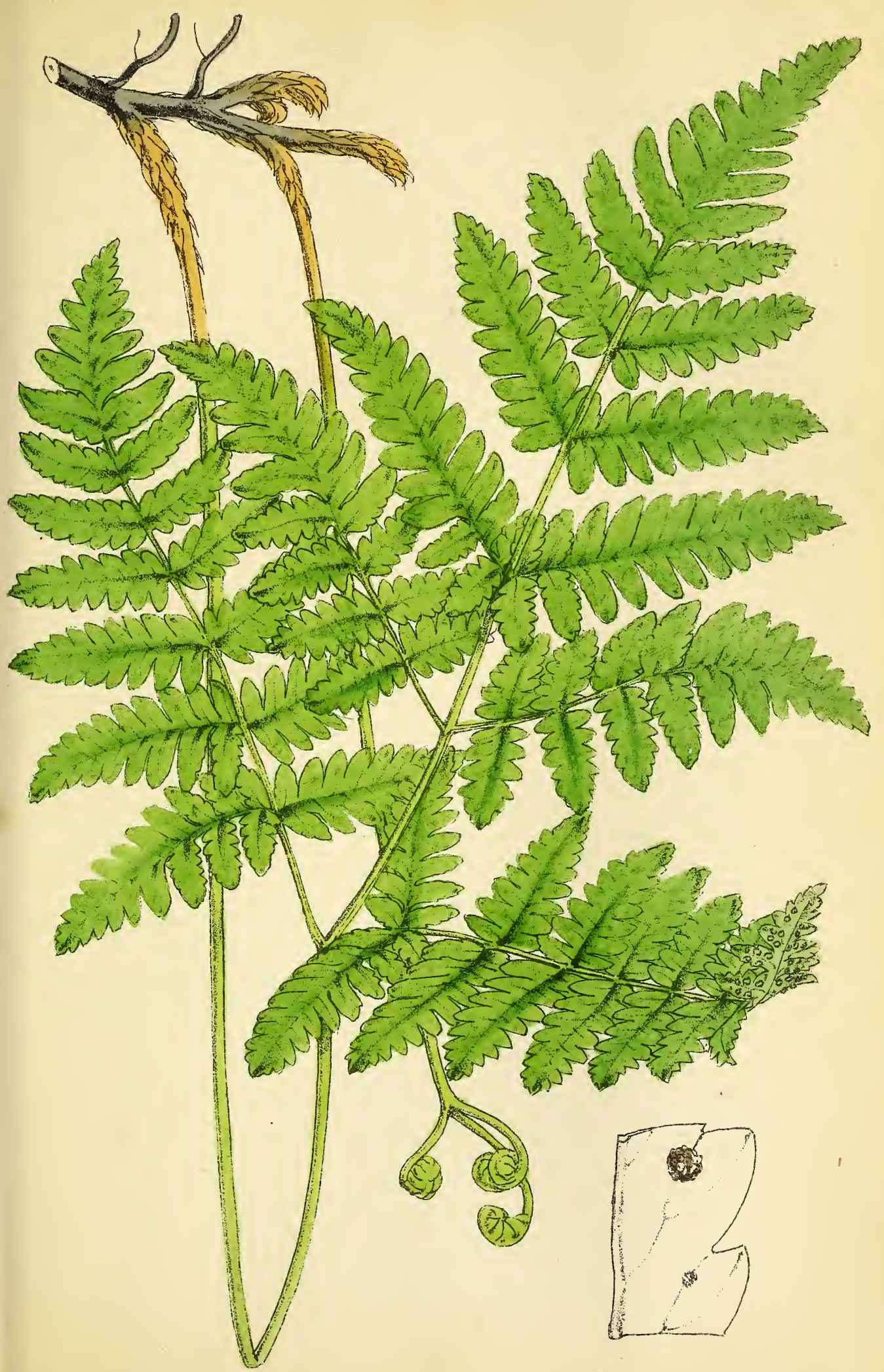

WFitch, del.et hth.

Vincent Brooks, Imp. 



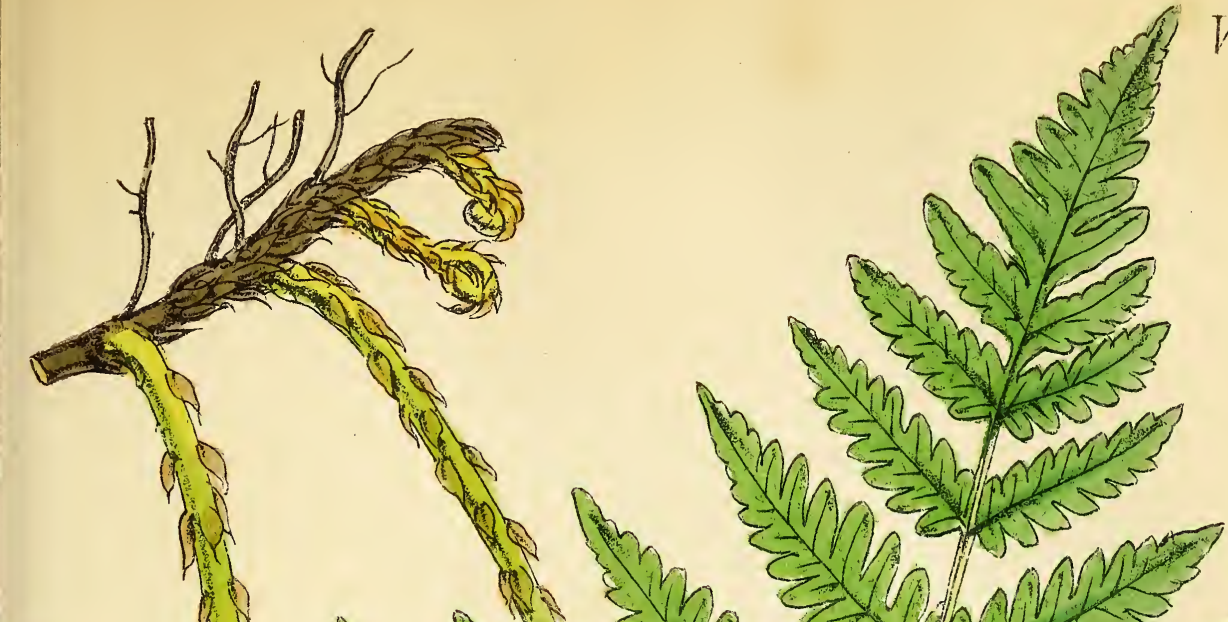

an $A$ L

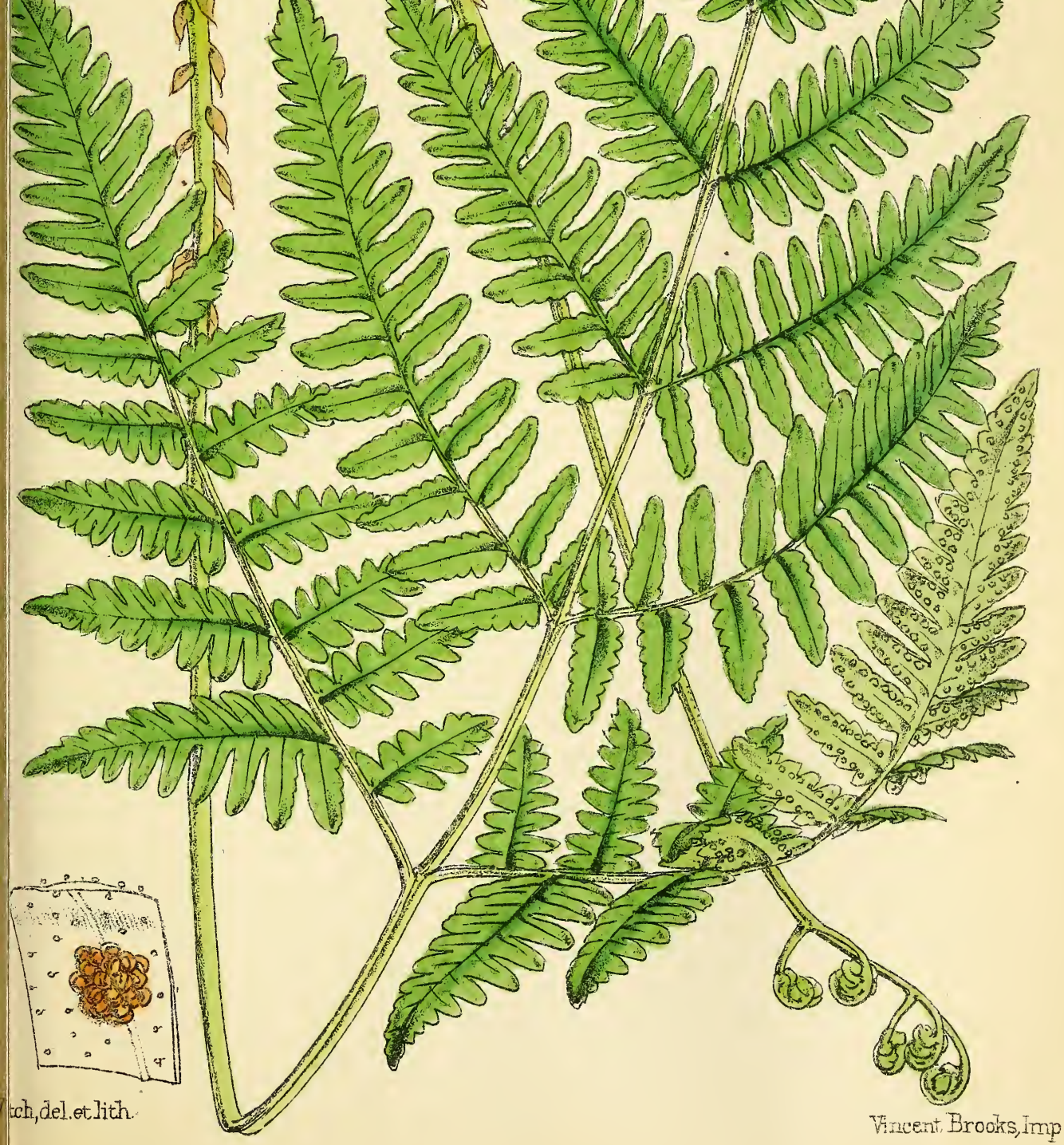






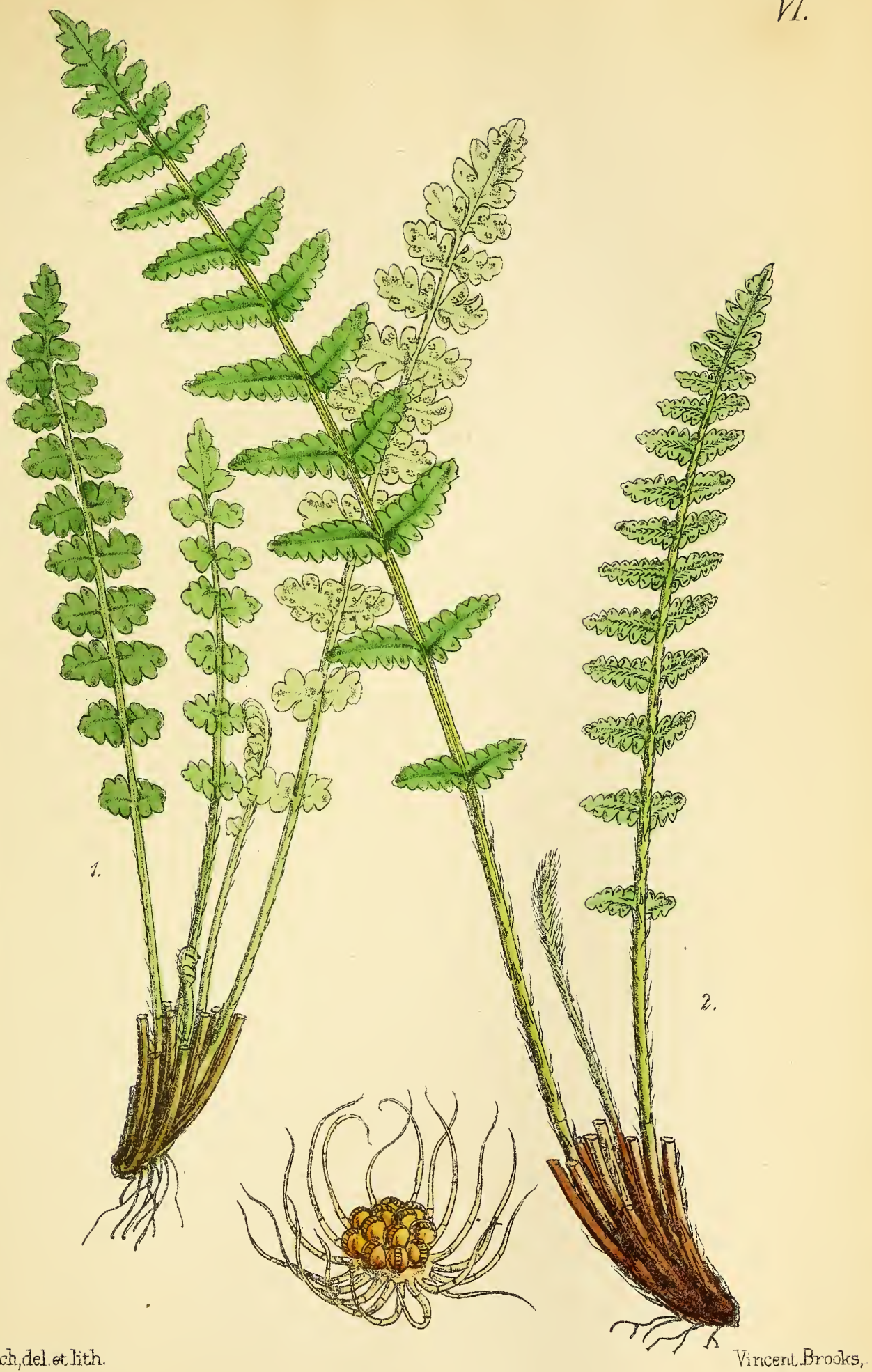

W.Titch, del et lith. 



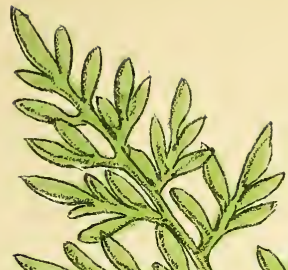

W
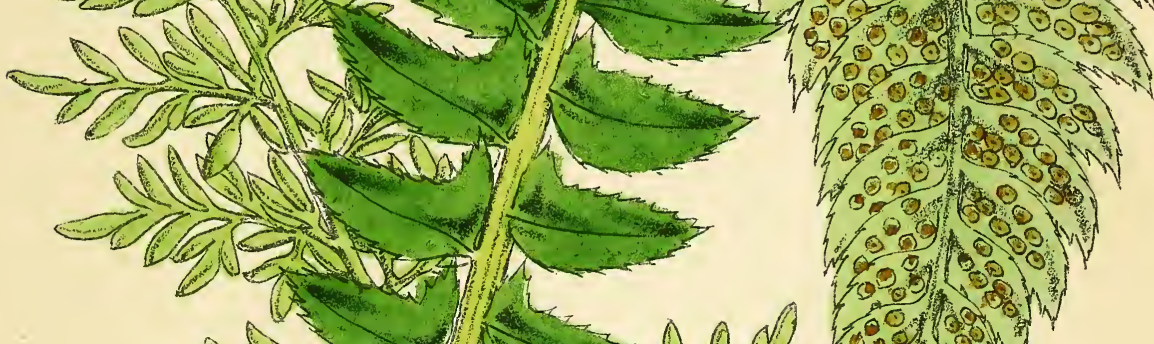

andy (metrem

Hinnum

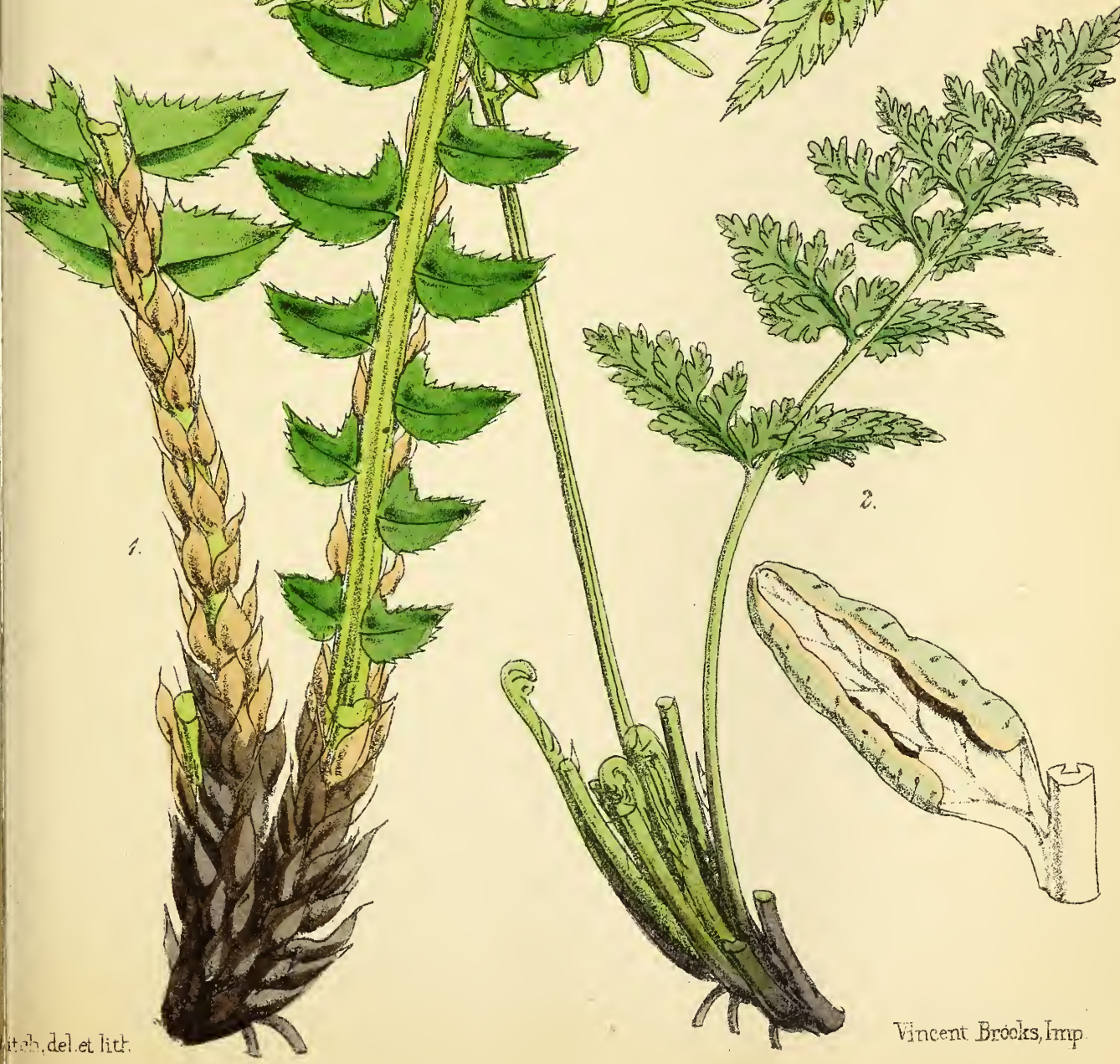





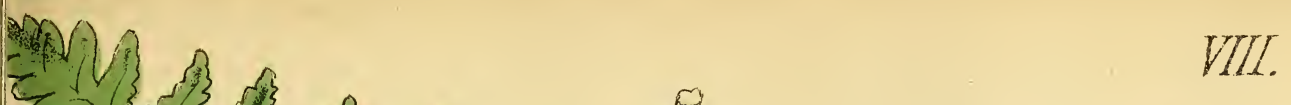
nst sim
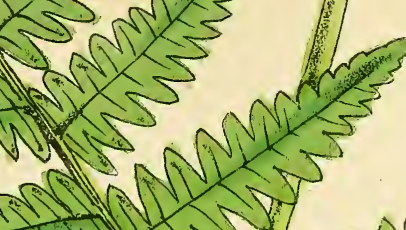

Enwhinh

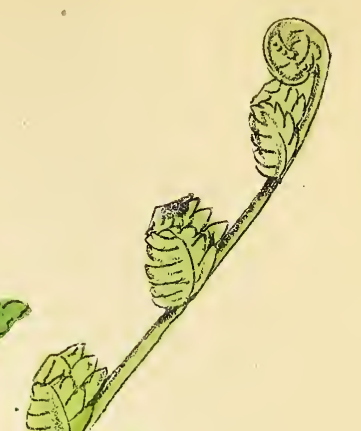

H.

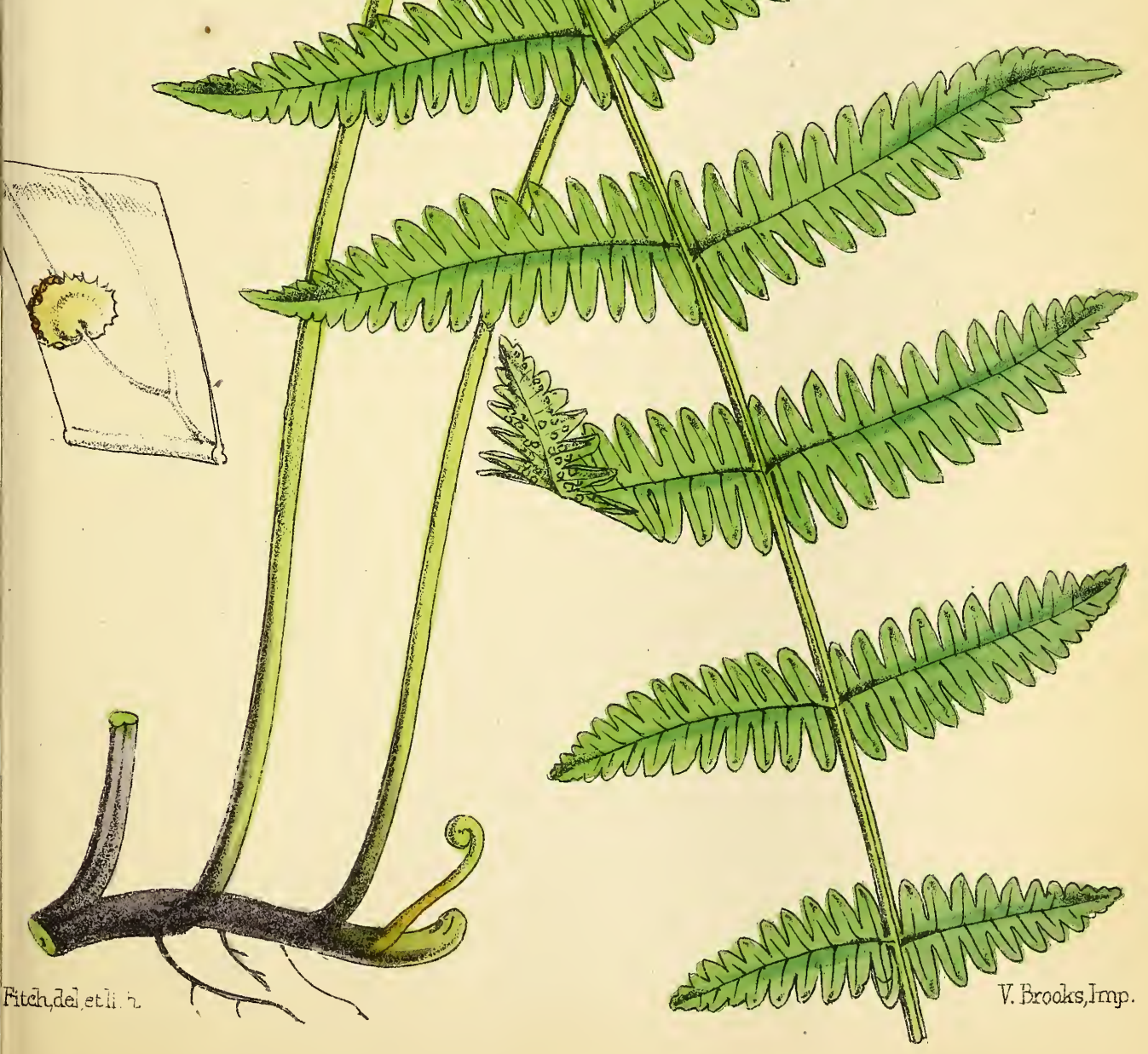





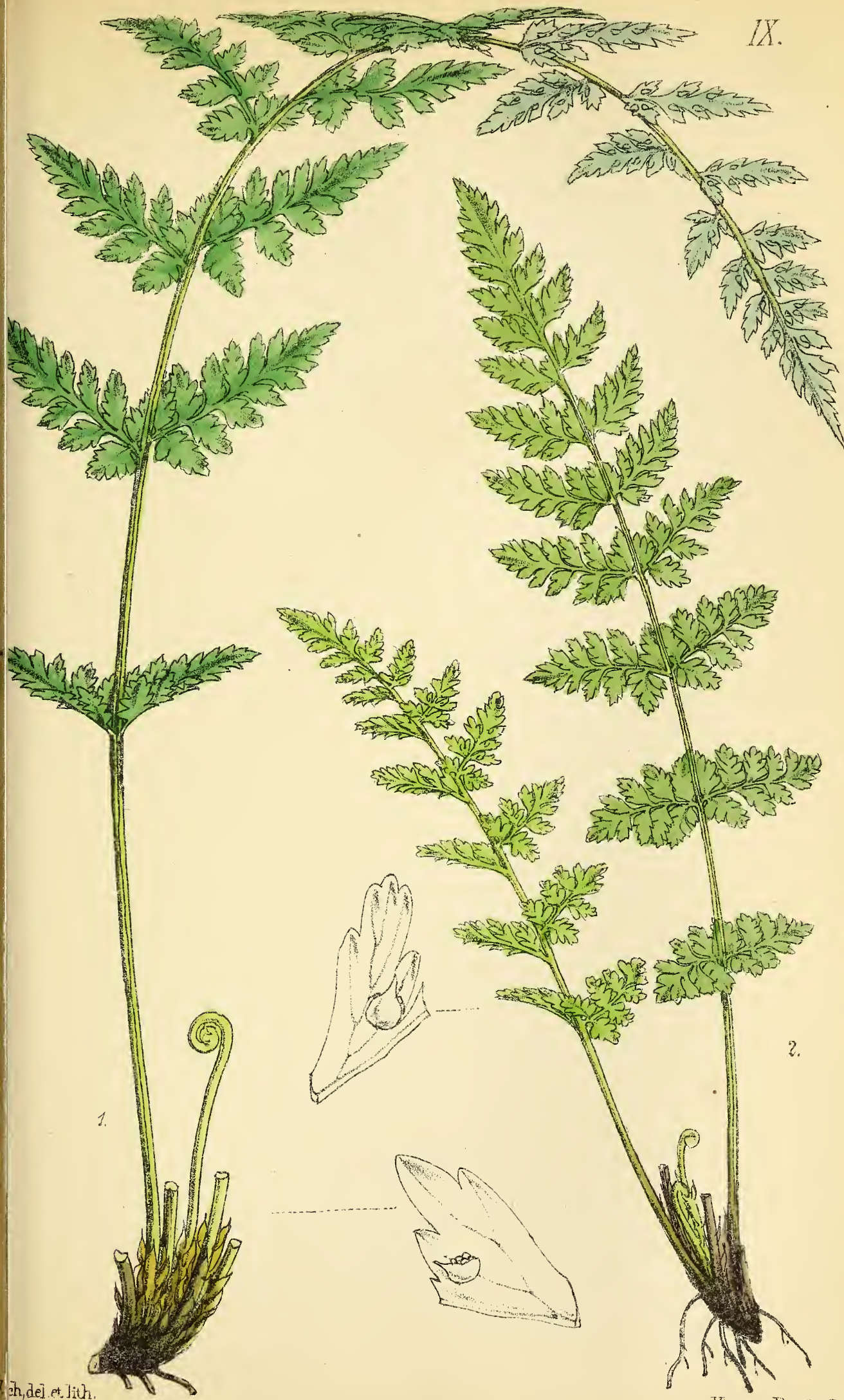

Vincent Brooks, Ino. 



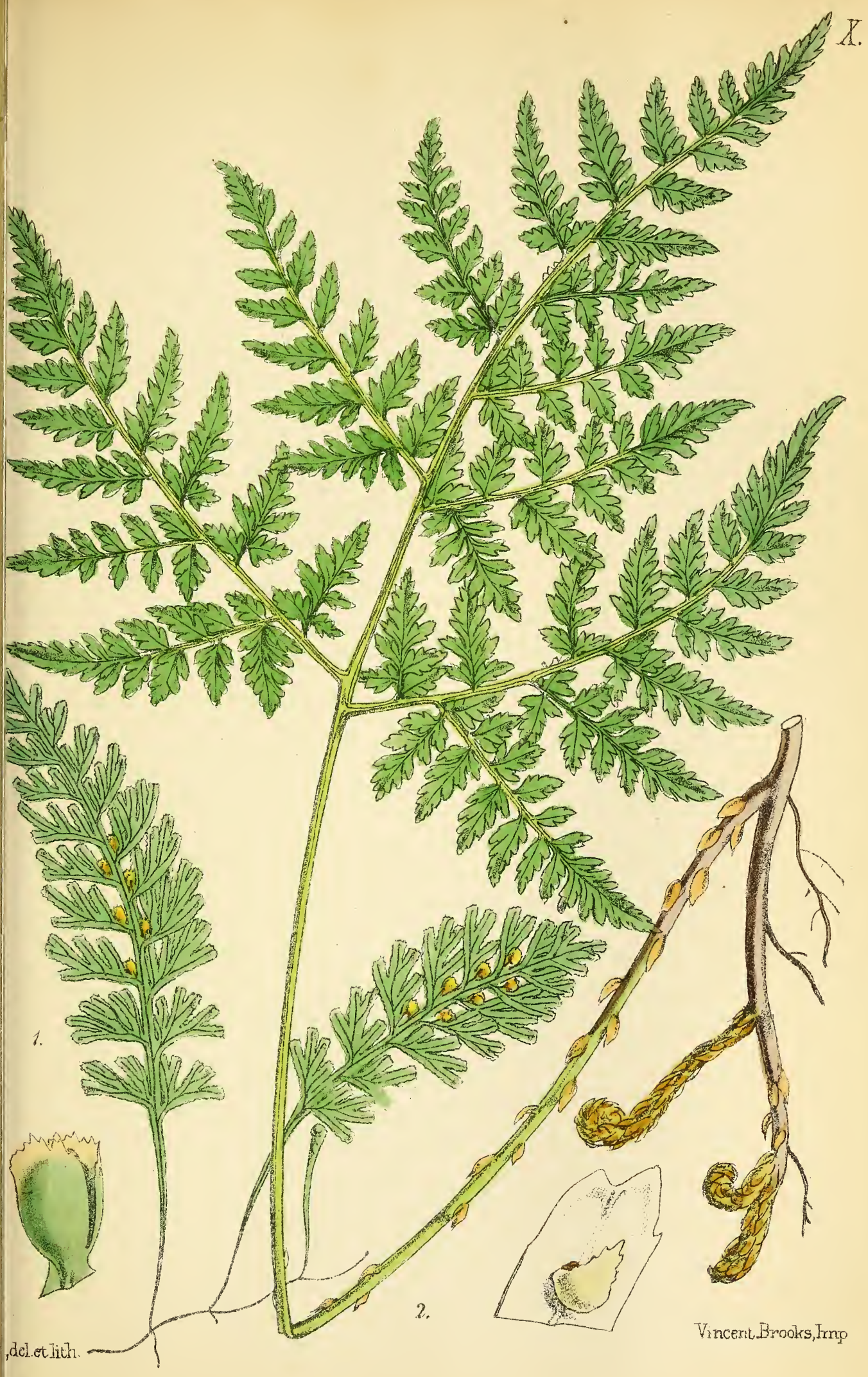






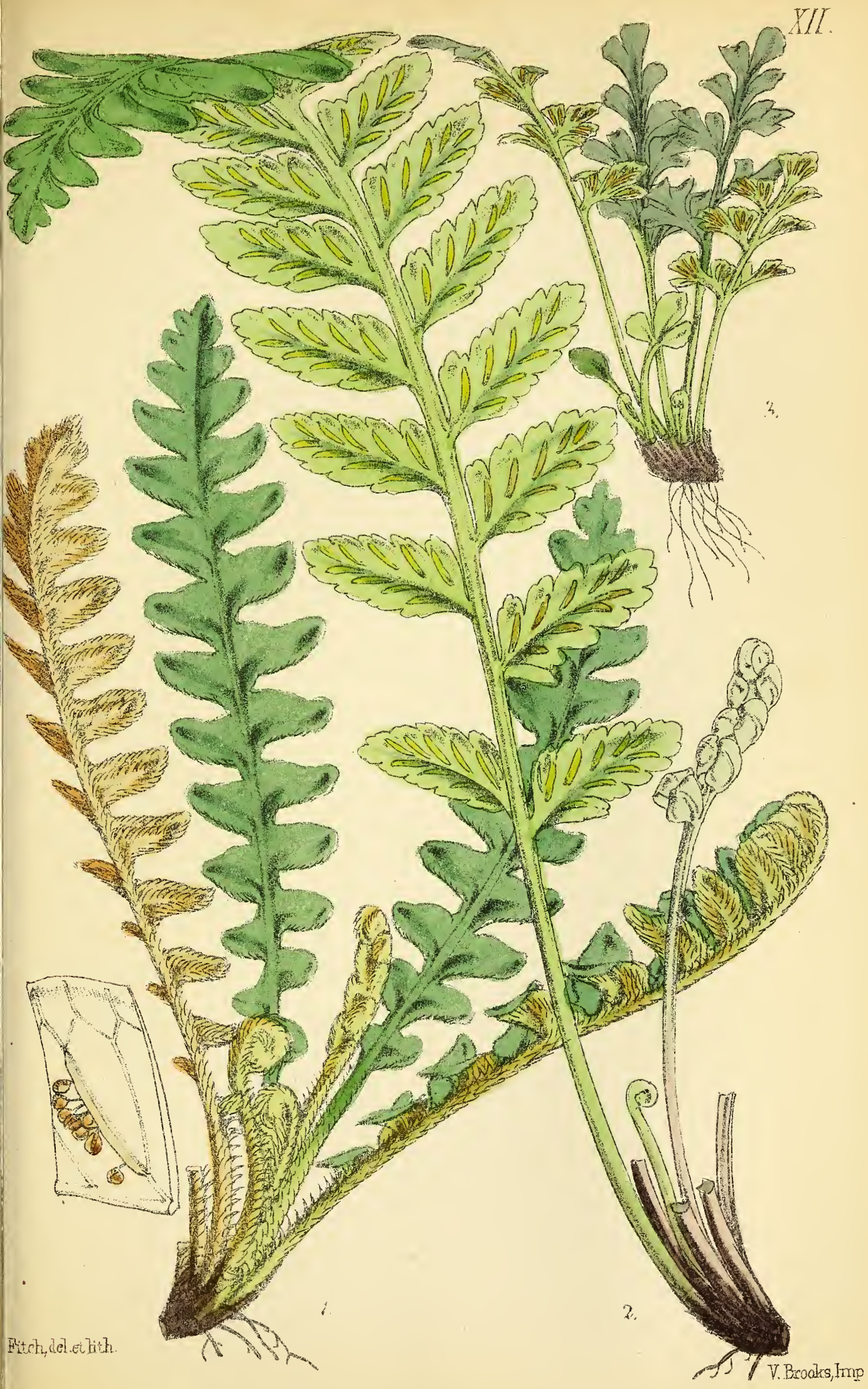





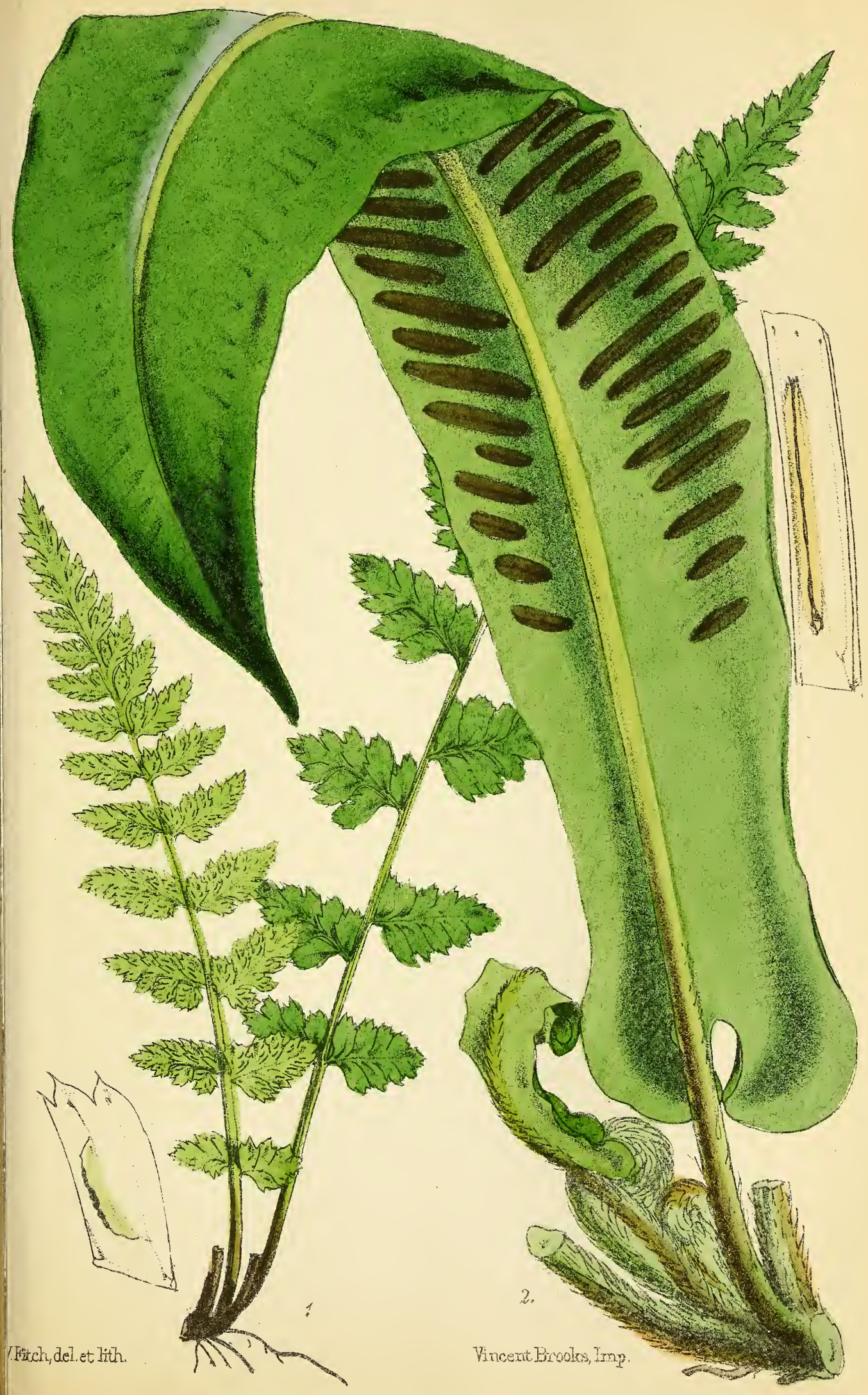





\section{XIV.}

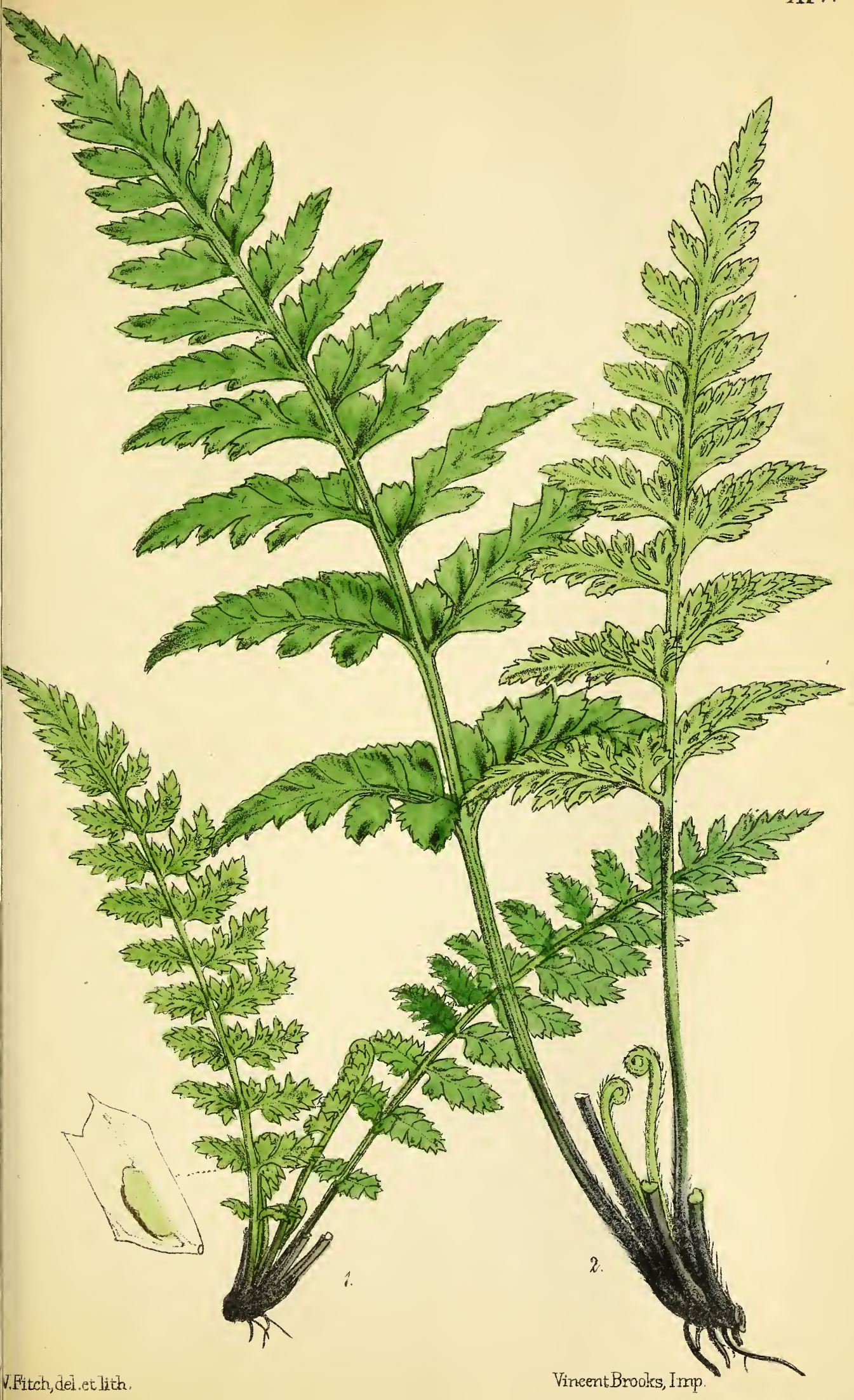





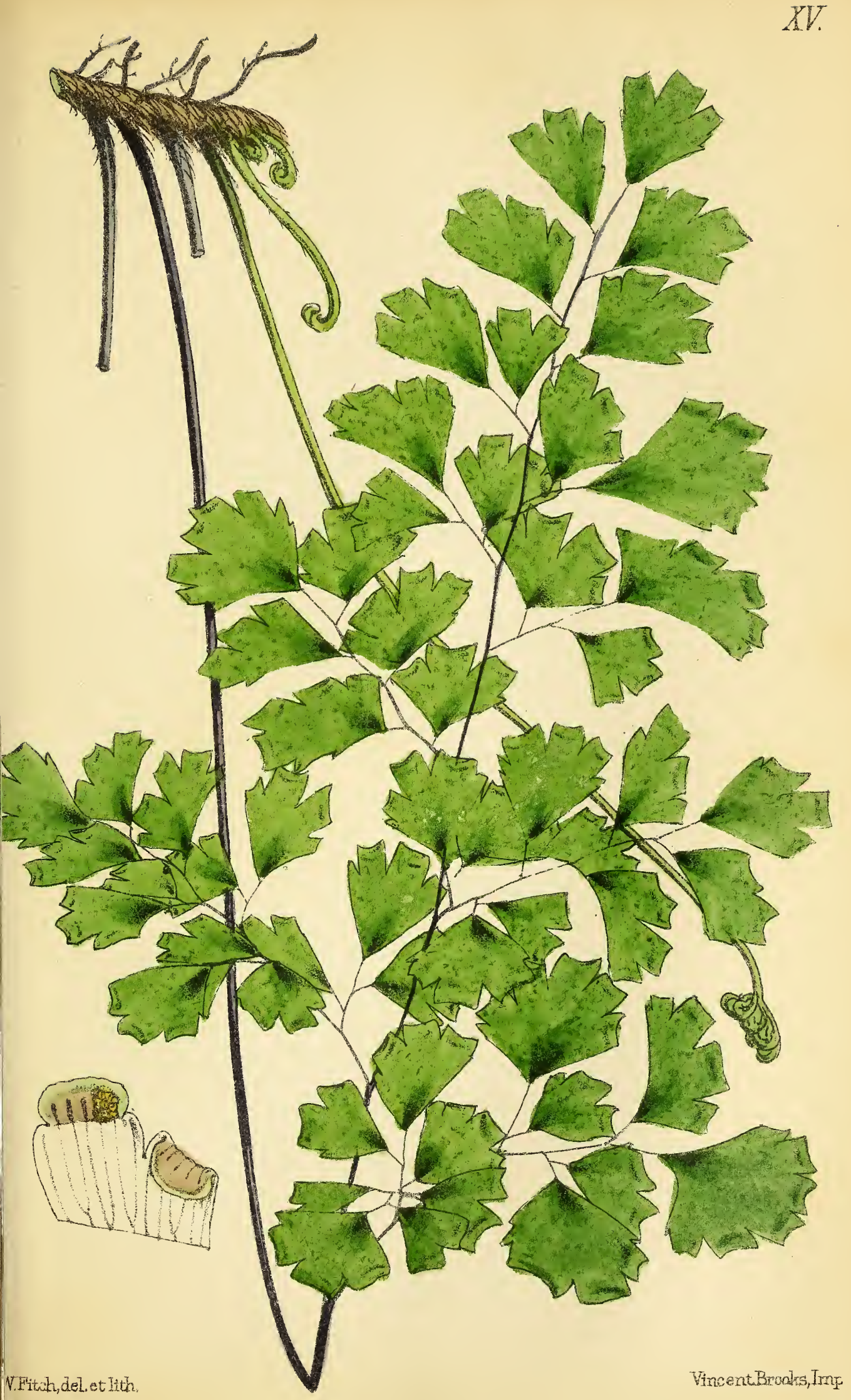





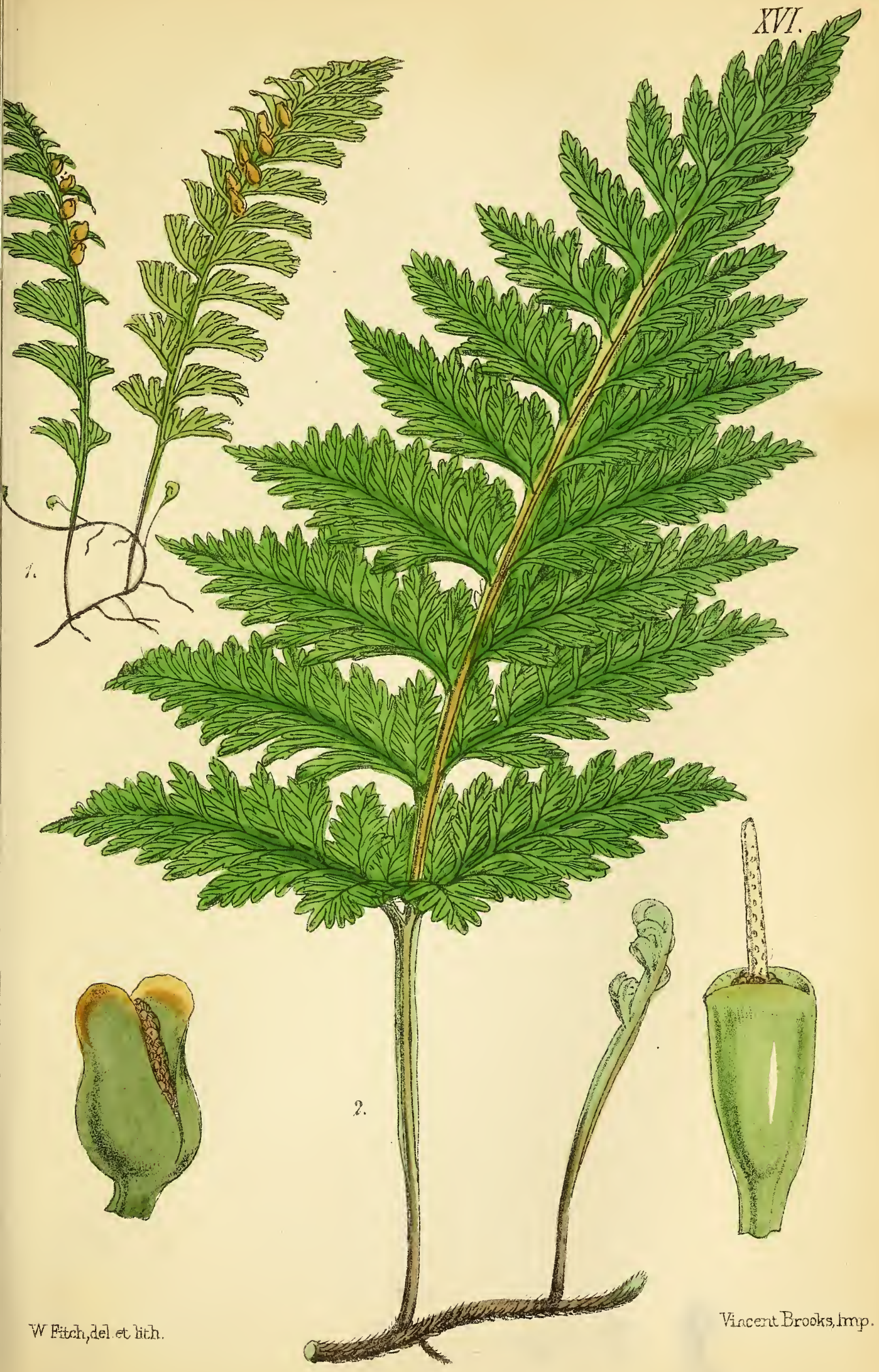





\section{LIST OF WORKS}

ON

BOTANY, ENTOMOLOGY, CONCHOLOGY,

TRAVELS, TOPOGRAPHY,

ANTIQUITY, AND MISCELLANEOUS

LITERATURE AND SCIENCE.

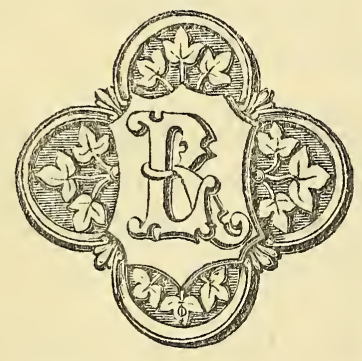

PUBLISHED BY

L. REEVE AND CO.,

5, HENRIETTA STREET, COVENT GARDEN, W.C. 


\section{NEW SERIES OF POPULAR NATURAL HISTORY FOR BEGINNERS AND} AMATEURS.

British Insects; a Familiar Description of the Form, Structure, Habits, and Transformations of Insects. By E. F. Staveley. Crown 8vo, 16 Coloured Plates, and numerous Wood Engravings, 14s.

British Butterflies and Moths; an Introduction to the Study of our Native Lepidoptera. By H. T. Stainton. Crown 8vo, 16 Coloured Plates, and Wood Engravings, 10s. 6d.

British Beetles; an Introduction to the Study of our indigenous Coleoptera. By E. C. RYe. Crown 8vo, 16 Coloured Plates, and 11 Wood Engravings, 10s. 6d.

British Bees; an Introduction to the Study of the Natural History and Economy of the Bees indigenous to the British Isles. By W. E. Shuckard. Crown 8vo, 16 Coloured Plates, and Woodcuts, 10s. $6 d$.

British Spiders; an Introduction to the Study of the Araneide found in Great Britain and Ireland. By E. F. Staveley. Crown 8vo, 16. Coloured Plates, and 44 Wood Engravings, $10 s .6 d$.

British Grasses; an Introduction to the Study of the Grasses found in the British Isles. By M. Plues. Crown 8vo, 16 Coloured Plates, and 100 Wood Engravings, 10s. 6d.

British Ferns ; an Introduction to the Study of the Ferns, Lycopods, and EQUiseta indigenous to the British Isles. With Chapters on the Structure, Propagation, Cultivation, Diseases, Uses, Preservation, and Distribution of Ferns. By M. Plues. Crown 8vo, 16 Coloured Plates, and 55 Wood Engravings, $10 s .6 d$. 
British Seaweeds; an Introduction to the Study of the Marine ALGs of Great Britain, Ireland, and the Channel Islands. By S. O. Grax. Crown 8vo, 16 Coloured Plates, 10s. $6 d$.

\section{BOTANY.}

The Natural History of Plants. By H. Baillon, President of the Linnæan Society of Paris, Professor of Medical Natural History and Director of the Botanical Garden of the Faculty of Medicine of Paris. Super-royal 8vo. Vols I. to VI., with 2861 Wood Engravings, 25s. each.

Handbook of the British Flora; a Description of the Flowering Plants and Ferns indigenous to, or naturalized in, the British Isles. For the use of Beginners and Amateurs. By George Bentham, F.R.S. 4th Edition, revised, Crown 8vo, 12s.

Illustrations of the British Flora; a Series of Wood Engravings, with Dissections, of British Plants, from Drawings by W. H. FiтcH, F.L.S., and W. G. Sмгтн, F.L.S., forming an Illustrated Companion to Bentham's "Handbook," and other British Floras. 1306 Wood Engravings, 12s.

Domestic Botany ; an Exposition of the Structure and Classification of Plants, and of their uses for Food, Clothing, Medicine, and Manufacturing Purposes. Вy Јонм Sмгтн, A.L.S., ex-Curator of the Royal Gardens, Kew. Crown 8vo, 16 Coloured Plates and Wood Engravings, 16s.

British Wild Flowers, Familiarly Described in the Four Seasons. Вy Tномаs Moone, F.L.S. 24 Coloured Plates, $16 s$.

The Narcissus, its History and Culture, with Coloured Figures of all known Species and Principal Varieties. By F. W. Burbidge, and a Review of the Classification by J. G. BAKer, F.L.S. Super-royal 8vo, 48 Coloured Plates, 32s.

Wild Flowers of the Undercliff, Isle of Wight. By Chardotte 0’Brien and C. Pariinson. Crown 8ro, 8 Coloured Plates, $7 s .6 d$. 
The Botanical Magazine ; Figures and Descriptions of New and Rare Plants of interest to the Botanical Student, and suitable for the Garden, Stove, or Greenhouse. By Sir J. D. Hоorer, K.C.S.I., C.B., F.R.S., Director of the Royal Gardens, Kew. Royal 8vo. Third Series, Vols. I. to XXXVI., each 42s. Published Monthly, with 6 Plates, 3s. 6d., coloured. Annual Subscription, $42 s$.

Re-Issue of the Third Series in Monthly Vols., 42s. each; to Subscribers for the entire Series, $36 s$. each.

The Floral Magazine; New Series, Enlarged to Royal 4to. Figures and Descriptions of the choicest New Flowers for the Garden, Stove, or Conservatory. Vols. I. to IX., in handsome cloth, gilt edges, $42 s$. each. Monthly, with 4 beautifullycoloured Plates, $3 s .6 d$. Annual Subscription, $42 s$.

First Series complete in Ten Vols., with 560 beautifully-coloured Plates, $187 s .6 d$.

The Young Collector's Handybook of Botany. By the Rev. H. P. Dunster, M.A. 66 Wood Engravings, $3 s .6 d$.

Laws of Botanical Nomenclature adopted by the International Botanical Congress, with an Historical Introduction and a Commentary. By Alphonse de Candolle. $2 s .6 d$.

Contributions to the Flora of Mentone, and to a Winter Flora of the Riviera, including the Coast from Marseilles to Genoa. By J. Traherne Moggridge, F.L.S. Royal 8vo. Complete in One Vol., with 99 Coloured Plates, $63 s$.

Flora Vitiensis; a Description of the Plants of the Viti or Fiji Islands, with an Account of their History, Uses, and Properties. By Dr. Berthold Semmann, F.L.S. Royal 4to, Coloured Plates, £8 5s.

Flora of Mauritius and the Seychelles; a Description of the Flowering Plants and Ferns of those Islands. By J. G. BAKER, F.L.S. 24s. Published under the authority of the Colonial Government of Mauritius. 
Flora of British India. By Sir J. D. Hooken, K.C.S.I., C.B., F.R.S., \&c. ; assisted by various Botanists. Parts I. to VIII., 10s. $6 d$. each. Vols. I. \& II., cluth, 32s. each. Published under the authority of the Secretary of State for India in Council.

Flora of Tropical Africa. By Daniml Obiver, F.R.S., F.L.S. Vols. I. to III., 20s. each. Published under the authority of the First Commissioner of Her Majesty's Works.

Handbook of the New Zealand Flora; a Systematic Description of the Native Plants of New Zealand, and the Chatham, Kermadec's, Lord Auckland's, Campbell's, and Macquarrie's Islands. By Sir J. D. Hooker, K.C.S.I., F.R.S. Complete in One Vol., 42s. Part II., CRYPTOGAMIA, separately, 14s. Published under the auspices of the Government of that Colony.

Flora Australiensis; a Description of the Plants of the Australian Territory. By George Benthand, F.R.S.s assisted by Ferdinand Muelder, F.R.S., Government Botanist, Melbourne, Victoria. Complete in Seven Vols., $£ 74 s$. Vols. I. to VI., 20s. each; Vol. VII., 24s. Published under the auspices of the several Governments of Australia.

Flora of the British West Indian Islands. By Dr. GrisebaCH, F.L.S. 37s. $6 d$. Published under the auspices of the Secretary of State for the Colonies.

Flora Hongkongensis; a Description of the Flowering Plants and Ferns of the Island of Hongkong. By George Bentham, F.R.S. With a Map of the Island, and a Supplement by Dr. HaNCE. 18s. Published under the authority of Her Majesty's Secretary of State for the Colonies. The Supplement separately, $2 s .6 d$.

Flora Capensis; a Systematic Description of the Plants of the Cape Colony, Caffraria, and Port Natal. By William H. Harvex, M.D., F.R.S., Professor of Botany in the University of Dublin, and Oтto Wilhem Sonder, Ph.D. Vols. I. and II., 12s. each. Vol. III., 18s. 
Elementary Lessons in Botanical Geography. By J. G. BAKER, F.L.S. $3 s$.

On the Flora of Australia: its Origin, Affinities, and Distribution; being an Introductory Essay to the "Flora of Tasmania." By Sir J. D. Hooker, F.R.S. $10 s$.

Genera Plantarum, ad Exemplaria imprimis in Herbariis Kewensibus servata definita. By George BenthaM, F.R.S., F.L.S., and Sir J. D. Hooker, F.R.S., Director of the Royal Gardens, Kew. Vol. I.-Part I., Royal 8vo, 21s.; Part II., 14s.; Part III., 15s.; or Vol. I. complete, 50s. Vol. II.Part I., 24s.; Part II. 32s.; or Vol. II. complete, 56s. Vol. III.Part I., 24s.

Illustrations of the Genus Carex. By Francis Boort, M.D. Folio, 600 Plates. Part I., £12; Parts II. and III., £6 each; Part IV., £12.

Illustrations of the Nueva Quinologia of Pavon, with Observations on the Barks described. By J. E. Howard, F.L.S. With 27 Coloured Plates. Imperial folio, half-morocco, gilt edges, $£ 66$ s.

The Quinology of the East Indian Plantations. By J. E. Howard, F.L.S. Complete in One Vol., folio. With 13 Coloured and 2 Plain Plates, and 2 Photo-prints, 84s. Parts II. and III., cloth, $63 s$.

Revision of the Natural Order Hederaceæ; being a reprint, with numerous additions and corrections, of a series of papers published in the "Journal of Botany, British and Foreign." By Berthold Seemann, Ph.D., F.L.S. 7 Plates, 10s. $6 d$.

Icones Plantarum. Figures, with Brief Descriptive Characters and Remarks, of New and Rare Plants, selected from the Author's Herbarium. By Sir W. J. Hooker, F.R.S. New Series, Vol. V. 100 Plates, 31s. 6d.

Botanical Names for English Readers. By RANDAL H. Aцcock. $8 \mathrm{vo}, 6 s$. 
Orchids; and How to Grow them in India and other Tropical Climates. By Samuex Jennings, F.L.S., F.R.H.S., late Vice-President of the Agri-Horticultural Society of India. Royal 4to. Complete in One Vol., cloth, gilt edges, $63 \mathrm{~s}$.

A Second Century of Orchidaceous Plants, selected from the Subjects published in Curtis's "Botanical Magazine" since the issue of the "First Century." Edited by JAMES BATEmaN, Esq., F.R.S. Complete in One Vol., Royal 4to, 100 Coloured Plates, £5 5s.

Dedicated by Special Permission to H.R.H. the Princess of Wales. Monograph of Odontoglossum, a Genus of the Vandeous Section of Orchidaceous Plants. By JaMes BatemaN, Esq., F.R.S. Imperial folio, complete in Six Parts, each with 5 Coloured Plates, and occasional Wood Engravings, 21s.; or, in One Vol., cloth, $£ 616 s .6 d$.

Select Orchidaceous Plants. By Robert Warner, F.R.H.S. With Notes on Culture by B. S. Wildiams. Folio, with 40 Coloured Plates, cloth gilt, $£ 77 s$.

Second Series, complete, with 39 Coloured Plates, $£ 7$ s.

Third Series, Parts I. to III., 10s. $6 d$. each.

The Rhododendrons of Sikkim-Himalaya; being an Account, Botanical and Geographical, of the Rhododendrons recently discovered in the Mountains of Eastern Himalaya, by Sir J. D. Hooker, F.R.S. By Sir W. J. Hooker, F.R.S. Folio, 30 Coloured Plates, £4 14s. 6 d.

Outlines of Elementary Botany, as Introductory to Local Floras. By George Bentham, F.R.S., President of the Linnæan Society. New Edition, $1 s$.

British Grasses; an Introduction to the Study of the Gramineæ of Great Britain and Ireland. By M. Plues. Crown 8vo, with 16 Coloured Plates and 100 Wood Engravings, 10 s. $6 d$.

Familiar Indian Flowers. By Lena Lowis. 4to, 30 Coloured Plates, 31s. $6 d$. 


\section{FERNS.}

British Ferns; an Introduction to the Study of the Ferns, Lycopods, and EQUiseta indigenous to the British Isles. With Chapters on the Structure, Propagation, Cultivation, Diseases, Uses, Preservation, and Distribution of Ferns. By M. Puuts. Crown 8vo, with 16 Coloured Plates, and 55 Wood Engravings, $10 s .6 d$.

The British Ferns ; Coloured Figures and Descriptions, with Analysis of the Fructification and Venation of the Ferns of Great Britain and Ireland. By Sir W. J. HоoKer, F.R.S. Royal $8 \mathrm{vo}, 66$ Coloured Plates, £2 $2 s$.

Garden Ferns; Coloured Figures and Descriptions with Analysis of the Fructification and Venation of a Selection of Exotic Ferns, adapted for Cultivation in the Garden, Hothouse, and Conservatory. By Sir W. J. Hooker, F.R.S. Royal 8vo, 64. Coloured Plates, £2 $2 s$.

Filices Exotica ; Coloured Figures and Description of Exotic Ferns. By Sir W. J. Hoorer, F.R.S. Royal 4to, 100 Coloured Plates, $£ 611 s$.

Ferny Combes ; a Ramble after Ferns in the Glens and Valleys of Devonshire. By Charlotte Chanter. Third Edition. Fcap. 8vo, 8 Coloured Plates and a Map of the County, $5 s$.

\section{MOSSES.}

Handbook of British Mosses, containing all that are known to be natives of the British Isles. By the Rev. M. J. Berkeley, M.A, F.L.S. 24 Coloured Plates, $21 s$.

Synopsis of British Mosses, containing Descriptions of all the Genera and Species (with localities of the rarer ones) found in Great Britain and Ireland. By Charles P. HовкіRк, President of the Huddersfield Naturalist's Society. Crown 8vo, 7s. $6 d$. 


\section{SEAWEEDS.}

British Seaweeds ; an Introduction to the Study of the Marine ALGe of Great Britain, Ireland, and the Channel Islands. By S. O. GraY. Crown 8vo, with 16 Coloured Plates, $10 s .6 d$.

Phycologia Britannica; or, History of British Seaweeds. Containing Coloured Figures, Generic and Specific Characters, Synonyms and Descriptions of all the Species of Algæ inhabiting the Shores of the British Islands. By Dr. W. H. Harvex, F.R.S. New Edition. Royal 8vo, 4 vols. 360 Coloured Plates, £7 10s.

Phycologia Australica; a History of Australian Seaweeds, comprising Coloured Figures and Descriptions of the more characteristic Marine Algæ of New South Wales, Victoria, Tasmania, South Australia, and Western Australia, and a Synopsis of all known Australian Algæ. By Dr. W. H. HARveY, F.R.S, Royal 8vo, Five Vols., 300 Coloured Plates, $£ 713 s$.

\section{FUNGI.}

Outlines of British Fungology, containing Characters of above a Thousand Species of Fungi, and a Complete List of all that have been described as Natives of the British Isles. By the Rev. M. J. Berkelex, M.A., F.L.S. 24 Coloured Plates, $30 s$.

The Esculent Funguses of England. Containing an Account of their Classical History, Uses, Characters, Development, Structure, Nutritious Properties, Modes of Cooking and Preserving, \&c. By C. D. Badham, M.D. Second Edition. Edited by F. Currey, F.R.S. 12 Coloured Plates, 12s.

Illustrations of British Mycology, comprising Figures and Descriptions of the Funguses of interest and novelty indigenous to Britain. By Mrs. T. J. Husser. Royal 4to, Second Series, 50 Coloured Plates, $£ 4$ 10s. 
Clavis Agaricinorum; an Analytical Key to the British Agaricini, with Characters of the Genera and Sub-genera. By Worthington G. Smith, F.L.S. 6 Plates, $2 s .6 d$.

\section{SHELLS AND MOLLUSKS.}

Testacea Atlantica; or, the Land and Freshwater Shells of the Azores, Madeiras, Salvages, Canaries, Cape Verdes, and Saint Helena. By T. Vernon Woldaston, M.A., F.L.S. Demy 8vo, 25s.

Elements of Conchology; an Introduction to the Natural History of Shells, and of the Animals which form them. By Lovelu Reeve, F.L.S. Royal 8vo, Two Vols., 62 Coloured Plates, £2 $16 s$.

Conchologia Iconica ; or Figures and Descriptions of the Shells of Mollusks, with remarks on their Affinities, Synonymy, and Geographical Distribution. By Lovelu Reeve, F.L.S., and G. B. Sowerby, F.L.S., complete in Twenty Vols., 4to, with 2727 Coloured Plates, half-calf, £178.

A detailed list of Monographs and Volumes may be had.

Conchologia Indica; Illustrations of the Land and Freshwater Shells of British India. Edited by Sruvanus Hanley, F.L.S., and William Theobald, of the Geological Survey of India. Complete in One Vol., 4to, with 160 Coloured Plates, £8 $5 s$.

The Edible Mollusks of Great Britain and Ireland, with the Modes of Cooking them. By M. S. Lovelz. Crown 8vo, with 12 Coloured Plates, $8 s .6 d$.

\section{INSECTS.}

Insecta Britannica; Vol. III., Diptera. By FraNCIS WALKER, F.L.S. 8vo, with 10 Plates, 25s. 
The Lepidoptera of Ceylon. By F. Moore, F.L.S. Parts I. to III. Medium 4to, each with 18 Plates, 31s. 6d., coloured; $16 s$., uncoloured. Published under the auspices of the Government of Ceylon.

The Larvæ of the British Lepidoptera, and their Food Plants. By Owen S. Wilson. With Life-size Figures, drawn and coloured from Nature by Eleanora Wilson. Superroyal 8vo. With 40 elaborately-coloured Plates, containing upwards of 600 figures of Larvæ, $63 s$.

British Insects. A Familiar Description of the Form, Structure, Habits, and Transformations of Insects. By E. F. Stavelex, Author of "British Spiders." Crown 8vo, with 16 Coloured Plates and numerous Wood Engravings, 14s.

British Beetles; an Introduction to the Study of our indigenous Coleoptera. By E. C. Rye. Crown 8vo, 16 Coloured Steel Plates, and 11 Wood Engravings, $10 s .6 d$.

British Bees; an Introduction to the Study of the Natural History and Economy of the Bees indigenous to the British Isles. By W. E. SHuckard. Crown 8vo, 16 Coloured Plates, and Woodcuts of Dissections, 10s. $6 d$.

British Butterflies and Moths; an Introduction to the Study of our Native Lepidoptera. By H. T. Statinton. Crown 8vo, 16 Coloured Plates, and Wood Engravings, 10s. 6d.

British Spiders; an Introduction to the Study of the Araneidze found in Great Britain and Ireland. By E. F. Staveley. Crown 8vo, 16 Coloured Plates, and 44 Wood Engravings, 10s. $6 d$.

Harvesting Ants and Trap-door Spiders; Notes and Observations on their Habits and Dwellings. By J. T. Moggridge, F.L.S. With a Supplement of $160 \mathrm{pp}$. and 8 additional Plates, 17s. The Supplement separately, cloth, $7 s .6 d$. 
Curtis's British Entomology. Illustrations and Descriptions of the Genera of Insects found in Great Britain and Ireland, Containing Coloured Figures, from Nature, of the most rare and beautiful Species, and in many instances, upon the plants on which they are found. Eight Vols., Royal 8vo, 770 Coloured Plates, £28.

\section{Or in Separate Mronographs.}

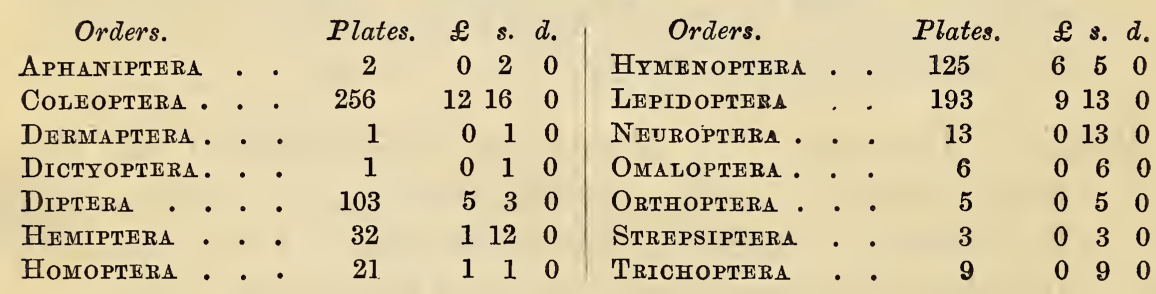

"Curtis's Entomology," which Cuvier pronounced to have "reached the ultimatum of perfection," is still the standard work on the Genera of British Insects. The Figures executed by the author himself, with wonderful minuteness and accuracy, have never been surpassed, even if equalled. The price at which the work was originally published was $£ 4316 s$.

\section{ANTIQUARIAN.}

Sacred Archæology; a Popular Dictionary of Ecclesiastical Art and Institutions from Primitive to Modern Times. Comprising Architecture, Music, Vestments, Furniture Arrangement, Offices, Customs, Ritual Symbolism, Ceremonial Traditions, Religious Orders, \&c., of the Church Catholic in all ages. By Mackenzie E. C. WaLcott, B.D. Oxon., F.S.A., Precentor and Prebendary of Chichester Cathedral. Demy 8vo, $18 s$.

A Manual of British Archæology. By Charles Boutelu, M.A. 20 Coloured Plates, 10s. $6 d$.

The Antiquity of Man; an Examination of Sir Charles Lyell's recent Work. By S. R. Patrison, F.G.S. Second Edition 8vo, $1 s$. 


\section{MISCELLANEOUS.}

Report on the Forest Resources of Western Australia. By Baron Ferd. Muelder, C.M.G., M.D., Ph.D., F.R.S., Government Botanist of Victoria. Royal 4to, 20 Plates, $12 s$.

West Yorkshire; an Account of its Geology, Physical Geography, Climatology, and Botany. By J. W. Davis, F.L.S., and F. Arnold Lees, F.I.S. Second Edition, 8vo, 21 Plates, many Coloured, and 2 large Maps, $21 s$.

Handbook of the Freshwater Fishes of India; giving the Characteristic Peculiarities of all the Species at present known, and intended as a guide to Students and District Officers. By Capt. R. Beavan, F.R.G.S. Demy 8vo, 12 plates, $10 s .6 d$.

Natal ; a History and Description of the Colony, including its Natural Features, Productions, Industrial Condition and Prospects. By Henry Brooks, for many years a resident. Edited by Dr. R. J. MANN, F.R.A.S., F.R.G.S., late Superintendent of Education in the Colony. Demy 8vo, with Maps, Coloured Plates, and Photographic Views, $21 s$.

St. Helena. A Physical, Historical, and Topographical Description of the Island, including its Geology, Fauna, Flora, and Meteorology. By J. C. Meluliss, A.I.C.E., F.G.S., F.L.S. In one large Vol., Super-royal 8vo, with 56 Plates and Maps, mostly coloured, 42s.

Isahore to Yarkand. Incidents of the Route and Natural History of the Countries traversed by the Expedition of 1870, under T. D. Forsyth, Esq., C.B. By George Henderson, M.D., F.L.S., F.R.G.S., and Aluan O. Hume, Esq., C.B., F.Z.S. With 32 Coloured Plates of Birds, 6 of Plants, 26 Photographic Views, Map, and Geological Sections, $42 s$.

The Birds of Sherwood Forest; with Observations on their Nesting, Habits, and Migrations. By W. J. SterLand. Crown 8vo, 4 plates. $7 s .6 d$., coloured. 
The Young Collector's Handy Book of Recreative Science. By the Rev. H. P. Dunster, M.A. Cuts, $3 s .6 d$.

The Zoology of the Voyage of H.M.S. Samarang, under the command of Captain Sir Edward Belcher, C.B., during the Years 1843-46. By Professor Owen, Dr. J. E. GraY, Sir J. Richardson, A. Adams, L. Reeve, and A. White. Edited by Arthur Adams, F.L.S. Royal 4to, 55 Plates, mostly coloured, $£ 310$ s.

A Survey of the Early Geography of Western Europe, as connected with the First Inhabitants of Britain, their Origin, Language, Religious Rites, and Edifices. By Henry LAWES Long, Esq. 8vo, $6 s$.

The Geologist. A Magazine of Geology, Palæontology, and Mineralogy. Illustrated with highly-finished Wood Engravings. Edited by S. J. Mackie, F.G.S., F.S.A. Vois. V. and VI., each with numerous Wood Engravings, 18s. Vol. VII., $9 s$.

Everybody's Weather-Guide. The use of Meteorological Instruments clearly explained, with directions for securing at any time a probable Prognostic of the Weather. By A. Steinmetz, Esq., Author of "Sunshine and Showers," \&c., $1 s$.

The Artificial Production of Fish. By Piscarius. Third Edition. $1 s$.

The Gladiolus : its History, Cultivation, and Exhibition. By the Rev. H. Honywood Dombrain, B.A. $1 s$.

Zoology. By Adrian J. Ebell, Ph.B., M.D. Part I., Structural Distinctions, Functions, and Classification of the Orders of Animals, $1 s$.

Meteors, Aerolites, and Falling Stars. By Dr. T. L. Phipson, F.C.S. Crown 8vo, 25 Woodcuts and Lithographic Frontispiece, 6s. 
Papers for the People. By One of Them. No. 1, Our Land. 8vo, 6d. (By Post, 7d. in stamps.)

The Royal Academy Album; a Series of Photographs from Works of Art in the Exhibition of the Royal Academy of Arts, 1875. Atlas 4to, with 32 fine Photographs, cloth, gilt edges, $£ 66 s$; ; half-morocco, $£ 77 s$.

The same for 1876, with 48 beautiful Photo-prints, cloth, $£ 66 s$. ; half-morocco, $£ 77 s$. Small Edition, Royal 4to, cloth, gilt edges, $63 s$.

On Intelligence. By H. TaINe, D.C.I. Oxon. Translated from the French by T. D. HAYE, and revised, with additions, by the Author. Complete in One Vol., 18s.

Manual of Chemical Analvsis, Qualitative and Quantitative; fur the use of Students. By Dr. Henry M. Noad, F.R.S. New Edition. Crown 8vo, 109 Wood Engravings, 16s. Or, separately, Part I., "QUALITATIVE," New Edition, new Notation, 6s.; Part II., "QUANTITATIVE," 10s. 6d.

Live Coals; or, Faces from the Fire. By L. M. BuDGer, "Acheta," Author of "Episodes of Insect Life," \&c. Dedicated, by Special Permission, to H.R.H. Field Marshal the Duke of Cambridge. Royal 4to, 35 Original Sketches printed in colours, $21 s$.

Caliphs and Sultans; being tales omitted in the ordinary English version of "The Arabian Nights' Entertainments," freely rewritten and rearranged. By S. HANLEY, F.L.S. $6 s$.

\section{PLATES.}

Floral Plates, from the Floral Magazine. Beautifully Coloured, for Screens, Scrap-books, Studies in Flower-painting, \&c. $6 d$. and 1s. each. Lists of over 700 varieties, One Stamp.

Botanical Plates, from the Botanical Magazine. Beautifully-coloured Figures of new and rare Plants. $6 d$. and $1 s$. each. Lists of over 2000, Three Stamps. 


\section{SERIALS.}

The Botanical Magazine. Figures and Descriptions of New and rare Plants. By Sir J. D. Hooker, C.B., F.R.S. Monthly, with 6 Coloured Plates, 3s. $6 d$. Annual subscription, post free, $42 s$.

Re-issue of the Third Series, in Monthly Vols., 42s. each; to Subscribers for the entire Series, 36s. each.

The Floral Magazine. New Series, enlarged to Royal 4to. Figures and Descriptions of Select New Flowers for the Garden, Stove, or Conservatory. Monthly, with 4 Coloured Plates, 3s. 6d. Annual Subscription, post free, $42 s$.

Select Orchidaceous Plants. By Robert Warner. Third Series. 3 Coloured Plates, 10s. $6 d$.

The Lepiduptera of Ocylon. By F. MonRe. $16 s$. plain ; 31s. 6d., coloured.

The Butterflies of Europe. By Dr. Lang, F.L.S. Monthly, with 4 Coloured Plates, 3s. $6 d$. Subscription for the complete Work (20 Parts), in advance, 60s.

\section{FORTHCOMING WORKS.}

Flora of Hampshire. By F. Townsend. Genera Plantarum. By Benthay and Hooker. Vol. III., Part II.

Flora of India. By Sir J. D. HookeR and others. Part IX.

Natural History of Plants. By Prof. BaIluon. Vol. VII.

Flora of Tropical Africa. By Prof. Ourver. Flora Capensis. By Prof. Dyer.

\section{整onvon:}

L. REEVE \& CO., 5, HENRIETTA STREET, COVENT GARDEN.

PRINTED BY GILBERT AND RIVINGTON, LIMITED, ST. JOHN'S SQUARE, LONDON. 








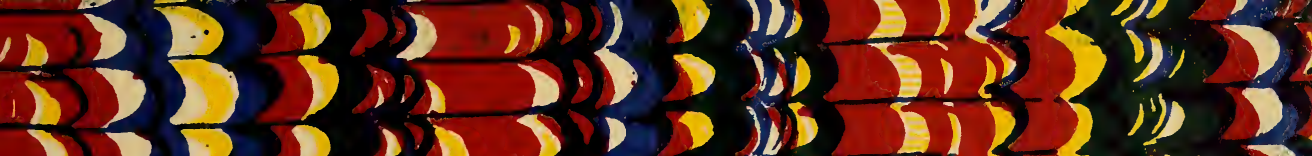

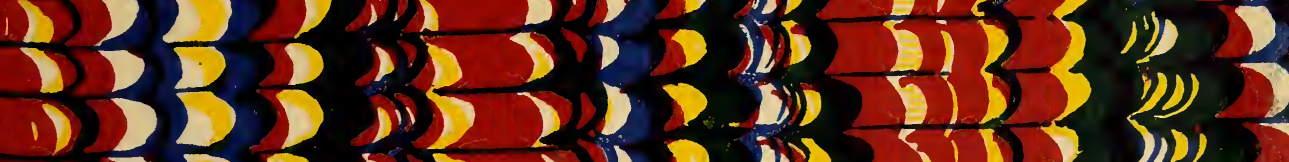

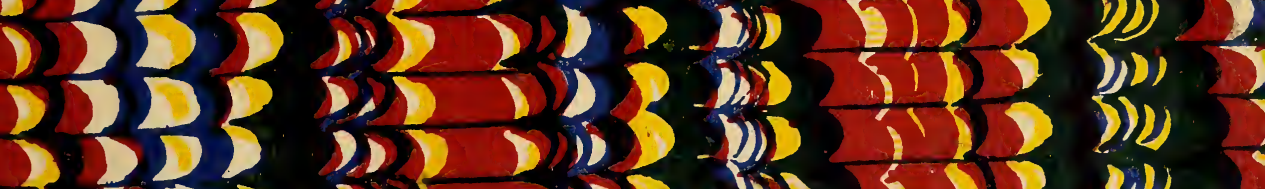

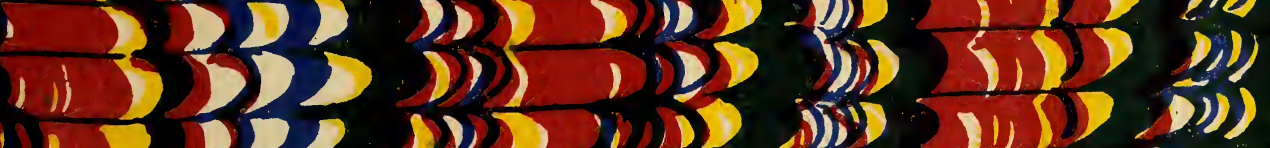

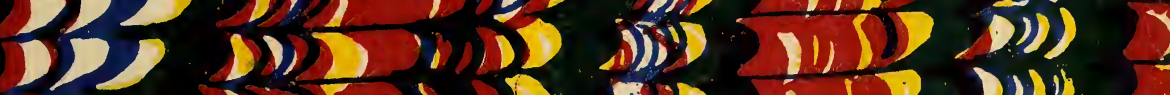

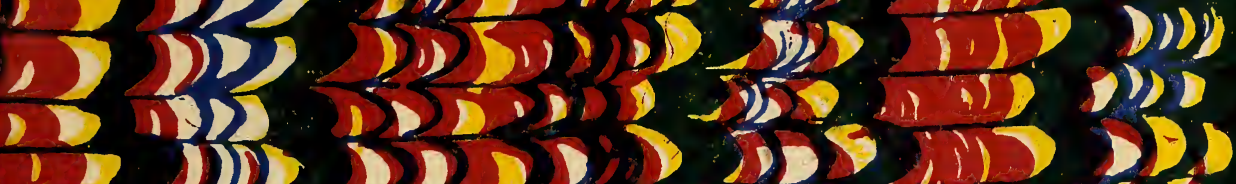
30) 5101255

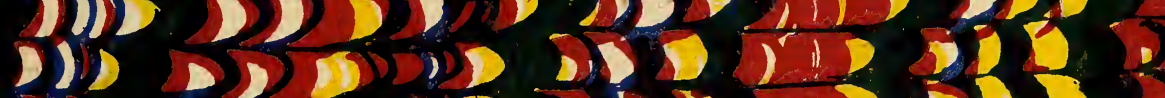

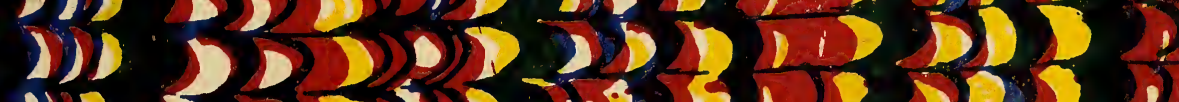

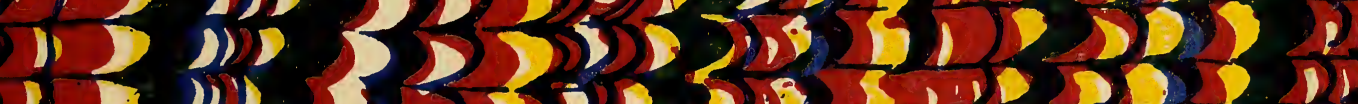
Di) 252023531.025211

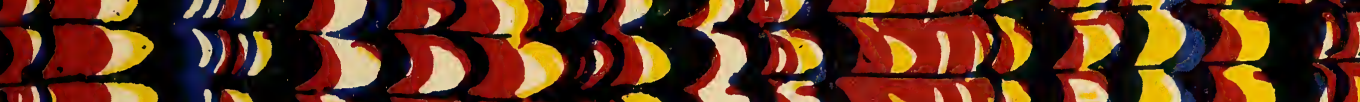
i) 2 is $5,2,1535$,1) 2053 1) 3 i) 3 iD 35052535 D) (1) $210,132,112$

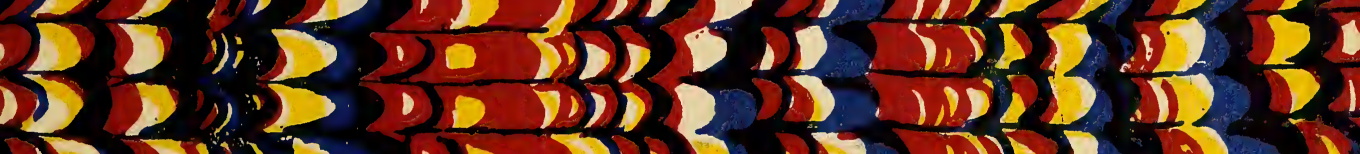

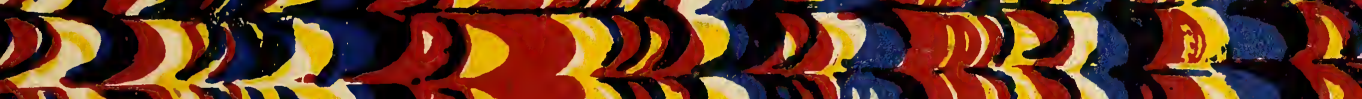

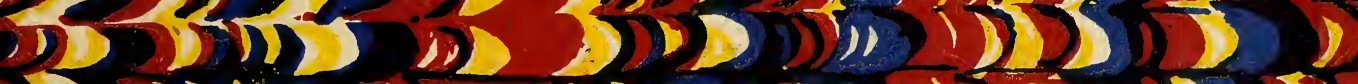

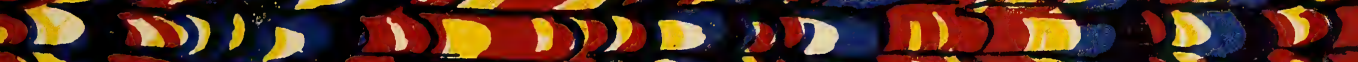

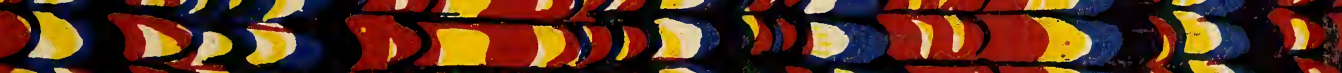

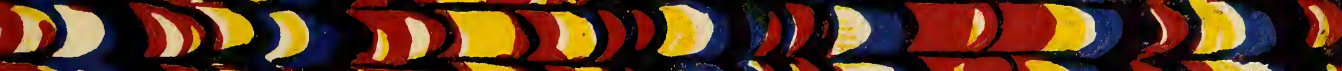

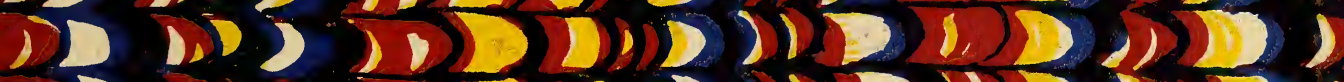

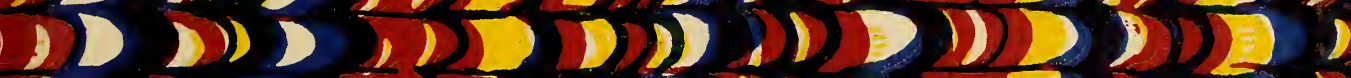

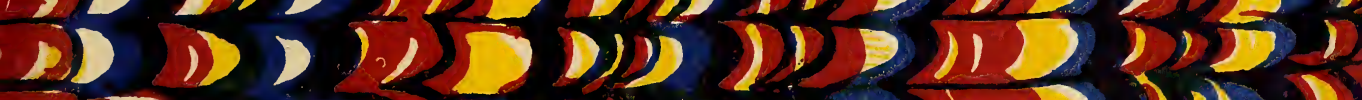
.02012112512012

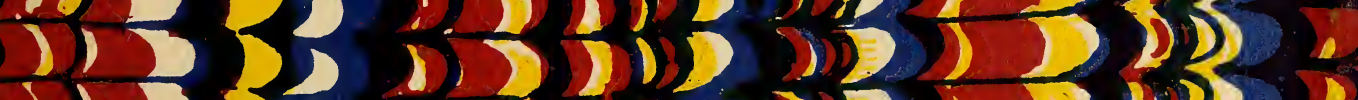

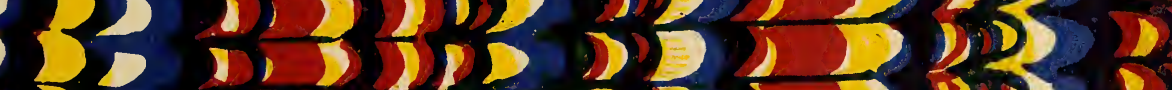

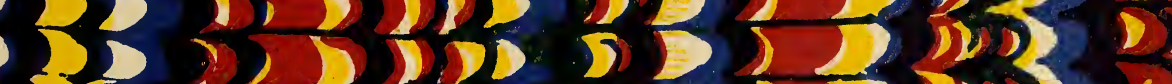

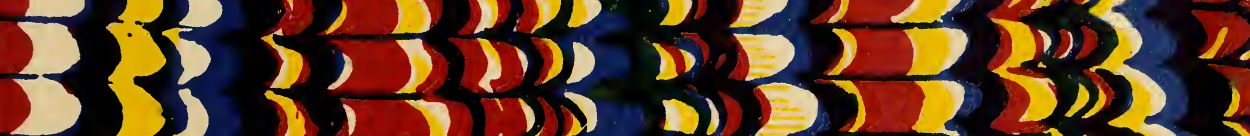

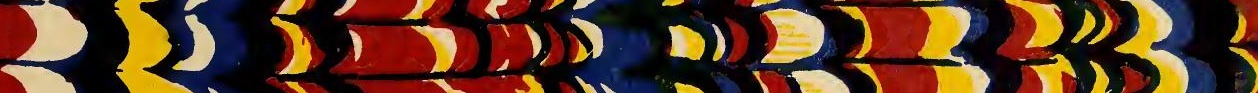
1,125201212

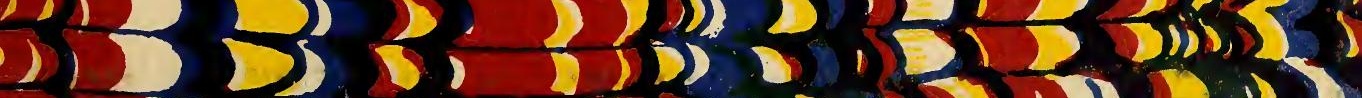

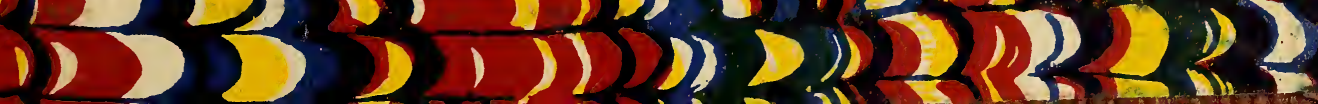


SMITHSONIAN INSTITUTION LIBRARIES 